71 I $42 \mathrm{C} 14$ MMM 
3
5
5

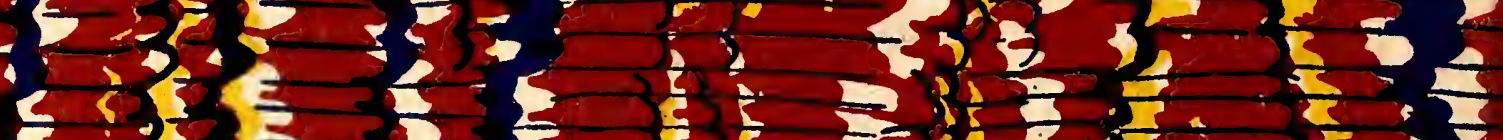

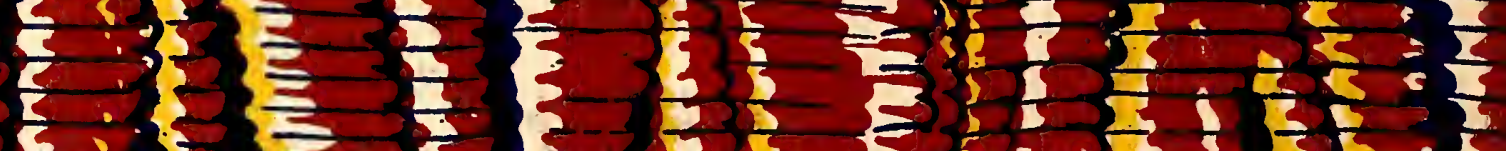

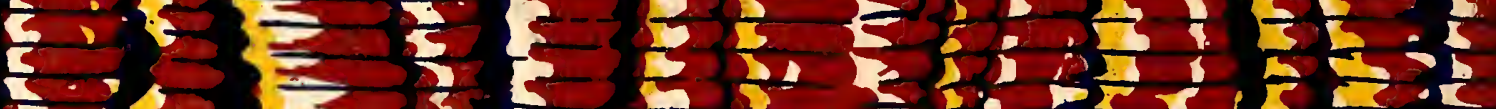

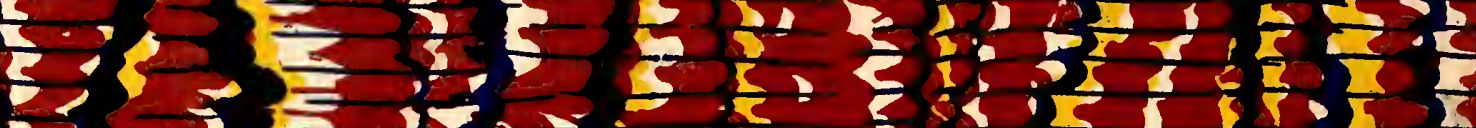

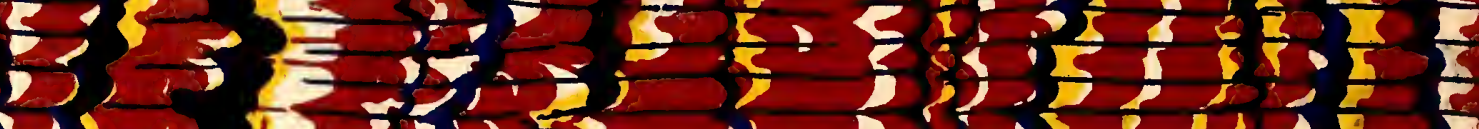

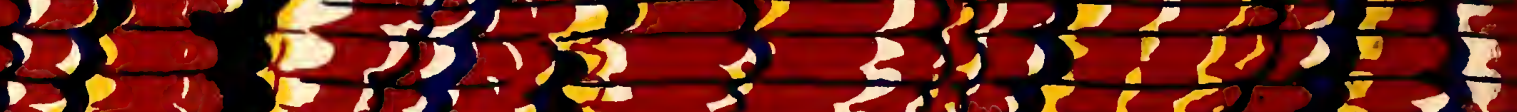

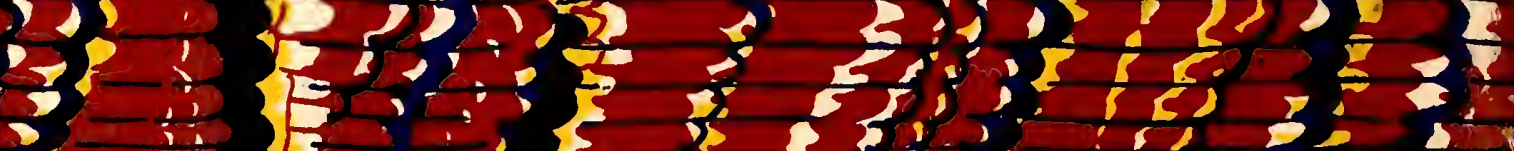

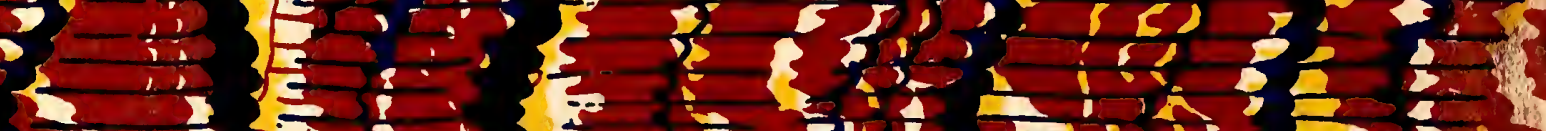

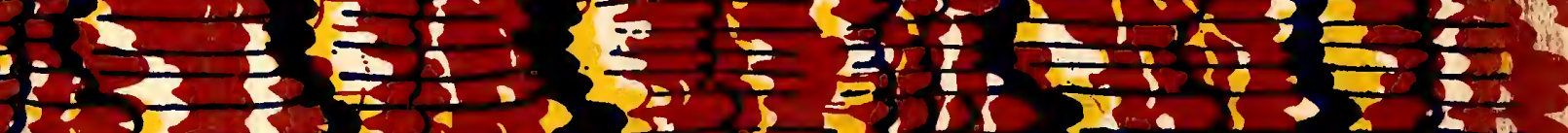

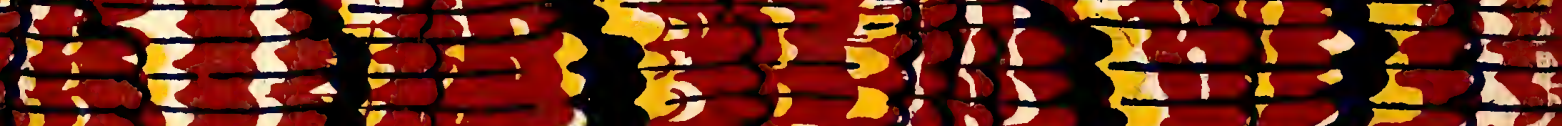
is

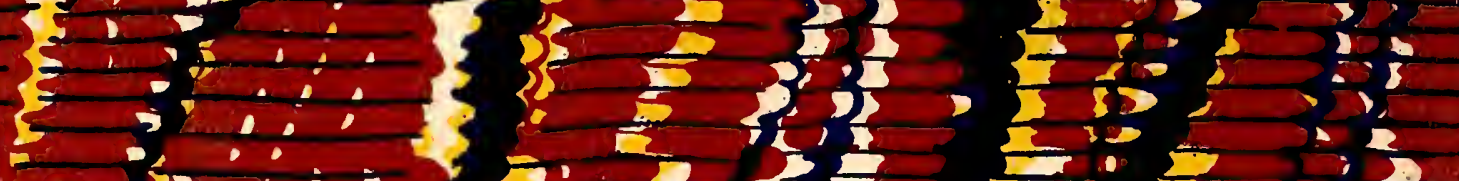

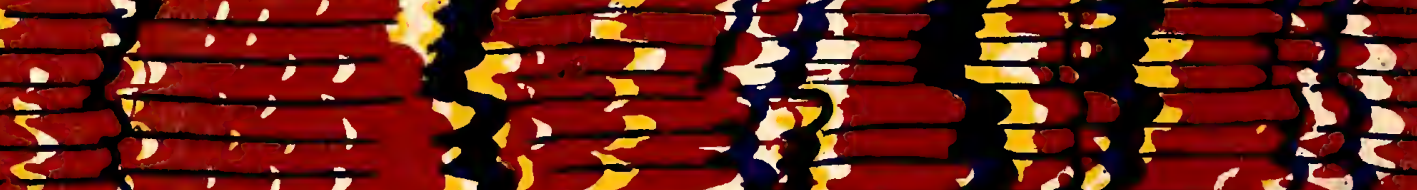

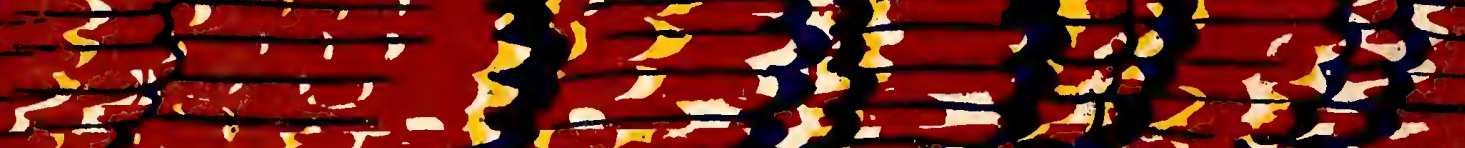

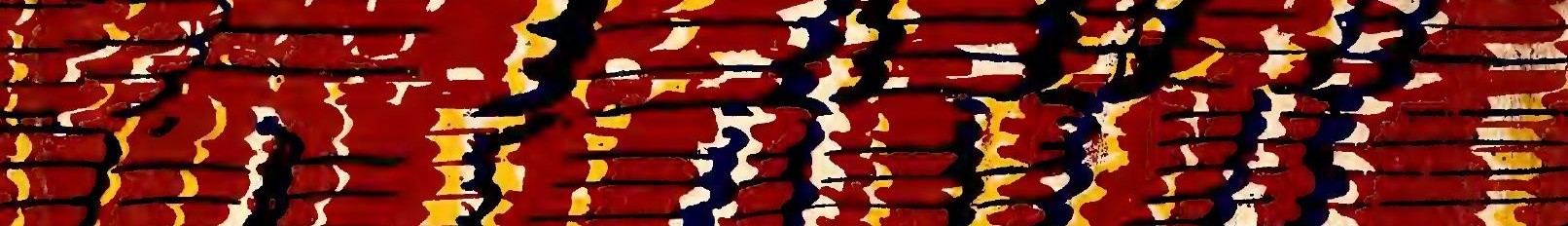

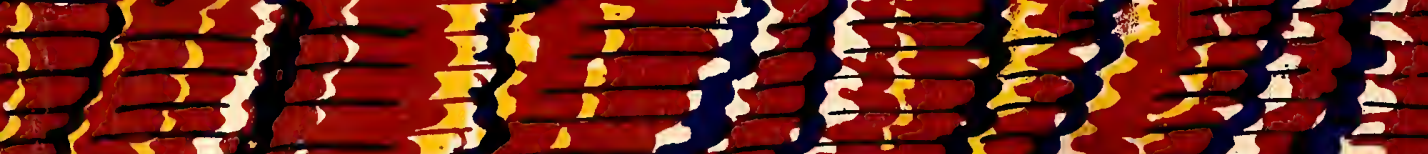
\{1: $5:$, - 1 , 320 S ISE

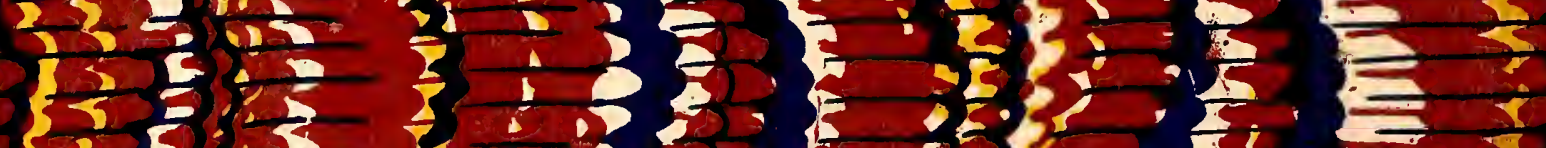

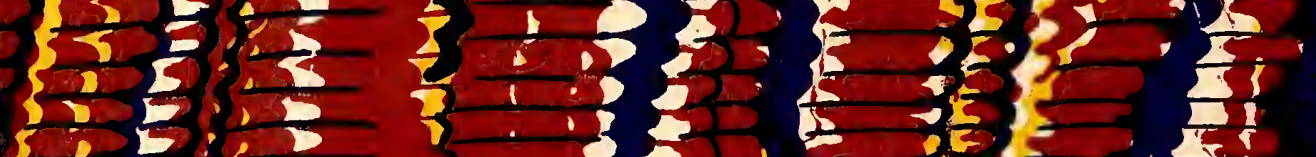
35 - 35 35 ,

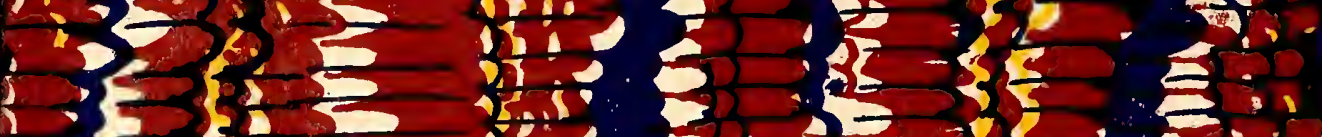
3. (3) 3 글 303 ,

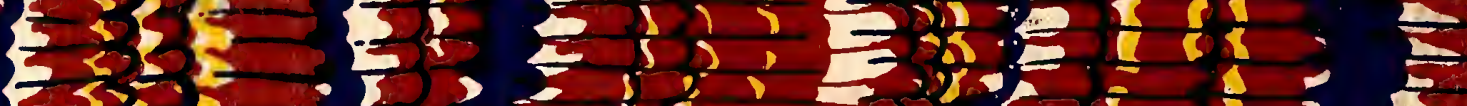

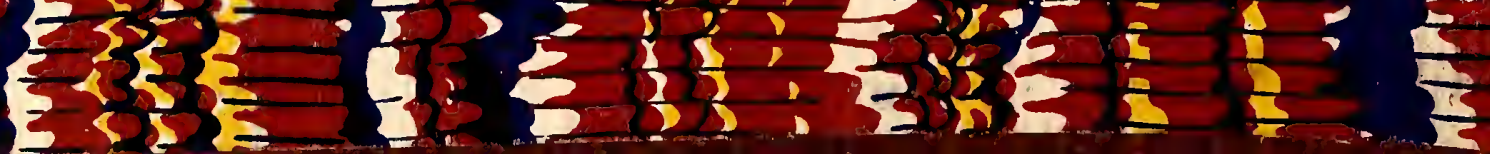






$$
M-1
$$







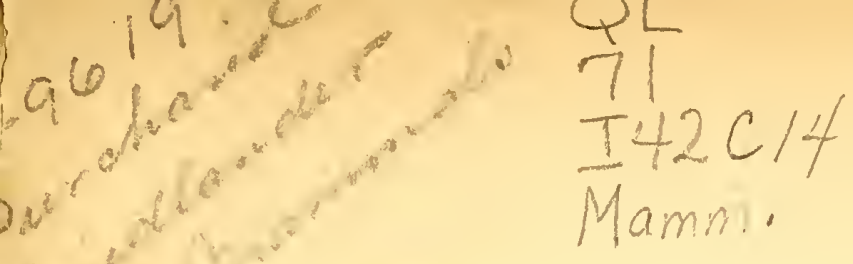

\section{CATALOGUE}

OE THE

\section{A II II A L I A}

IN THE

\section{USEUII ASIATIC SOCIETY,}

BY

E D A R D B L Y TH,

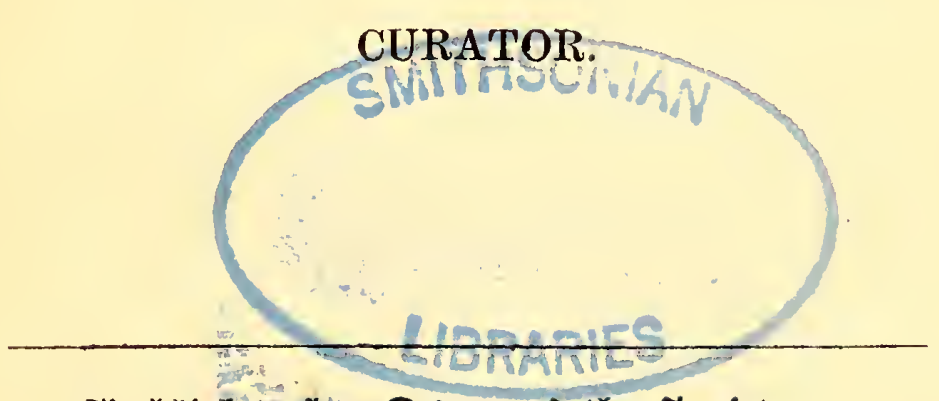

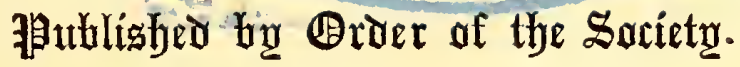

\section{A L C UT T A :}

SAVIELLE \& CRANENBURGH, BENGAL PRINTING COMPANT LIMITLD.

$$
\overline{863} \text {. }
$$



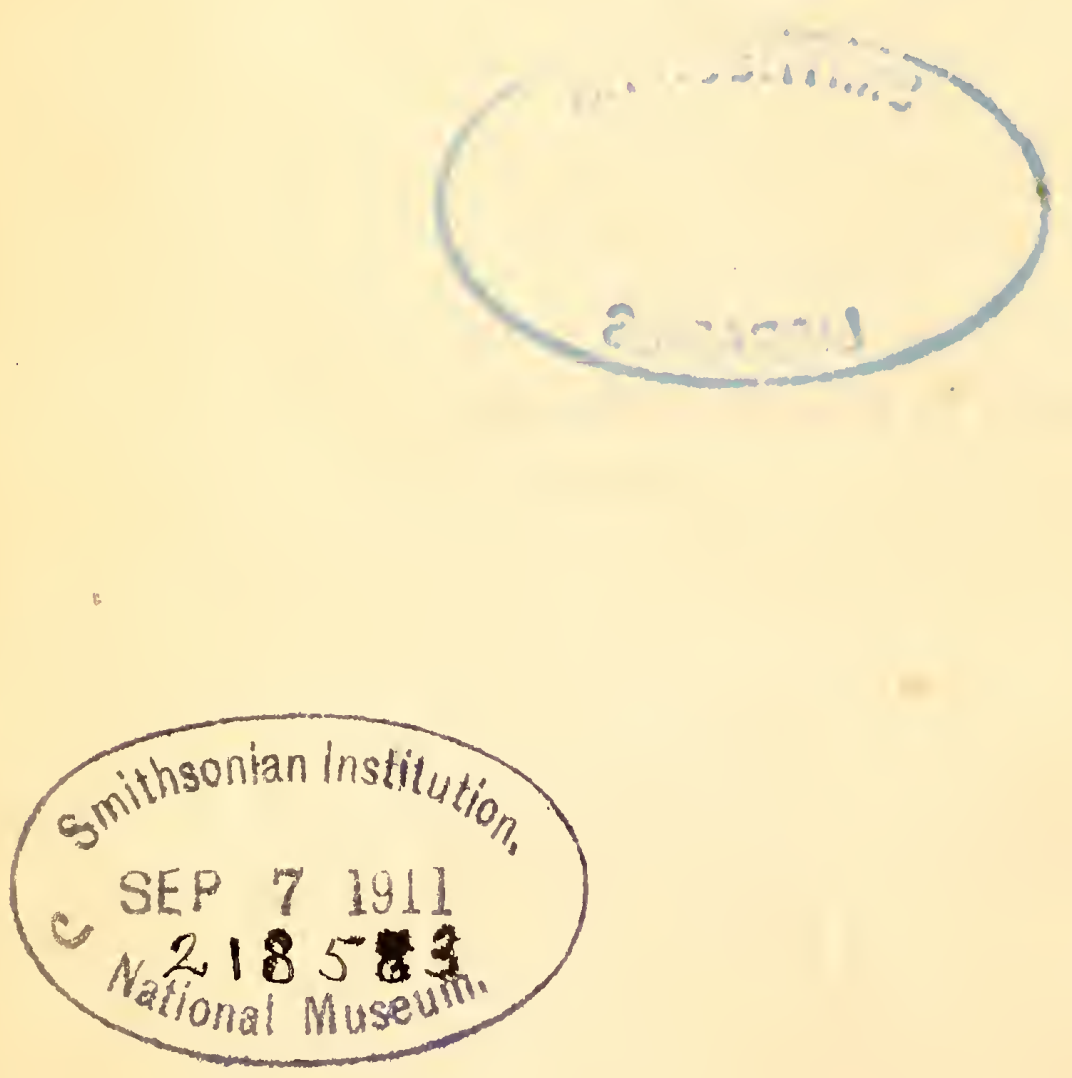


\section{PREF A CE.}

The following Catalogue of the specimens of the class Mammalia contained up to date in the Museum of the Asiatic Society, Calcutta, has been long in preparation. Periods of sickness and of absence have intervened; the excessively crowded state of our cases has added to the difficulty; and I have not had the advantage of the aid of a well qualified Assistant (as when drawing up the Catalogue of Birds) ; besides that I have had a variety of other works needing prompt attention, from time to time, and even much that $I$ have been quite unable to get through. My friend, Dr. Jerdon, will, indeed, kindly see to the correcting of the last few pages of the Catalogue for the press. In the collocations of synonyms, I have, of course, been greatly indebted to sundry of the British Museum Catalogue and synoptical papers of my friend Dr. J. E. Gray; but I have not implicitly followed that eminent Zoologist, especially as regards the habitats of various species, which, I believe, to be quite correetly assigned throughout the present volume. 



\section{LIST OF ERRATA.}

Page 15. No. 38, for Ph. read Pr.

$" 21$. " $\quad 57$, for $\mathrm{Pl}$. read $\mathrm{P}$.

"94. "291, for $\mathrm{Ph}$. read $\mathrm{Pt}$.

" 95. " 292, for $\mathrm{Pb}$. read $\mathrm{Pt}$.

"95. "293, for $\mathrm{Ph}$. read $\mathrm{Pt}$.

$"$ 110. Line 4th, for Yam. read Fam.

"125. No. 311, for M. read N.

"125. "312, for M. read $\mathrm{P}$.

"136. Line 8th, for A. read Eq.

"136. "20th, for E. read Eq.

"153. No. 491, for A. read $\mathrm{H}$.

From No. 251, p. 110, to No. 347, p. 132, read No. 351 to 447 ; and there are several other mistakes in the numbers, too numerous indeed to rectify here. 



\title{
CATALOGUE OF THE MAMMALIA
}

IN THE

\section{MUSEUM OF THE ASIATIC SOCIETY OF BENGAL.}

\author{
Kingdom ANIMALIA. \\ Sub-kingdom VERTEBRATA.
}

Class MAMMALIA. Sub-class PLACENTALIA. (?) ZoophagoIda. (?) Typodontia. Order PRIMATES. Sub-order CHEIROPODA. Tribe ANThropida. Sub-tribe Catarrhini.

Family HOMINID A. Sub-family HOMININAE. Genus Homo, L.

1. H. SAPIENS, L.

$A$. Skeleton of an European (English) male. Presented by Dr. Thompson (1842). B. Ditto of a Nicobarian (aged female apparently), in wrappings, as found hanging to a tree, according to custom in the Nicobar islands (J.A. S. XV, 351). Presented by Commander Russell, of the 'Ganges' Steamer (1846). C. Skull of a Chinese. Mr. W. Carr, J. A. S. V, 249 (1836). D. Ditto of Chinese (?), marked 'Burmese.' Presented by Ditto of Burmese. Presented by $\longrightarrow$ ? $F$. Ditto of Malay pirate: upper incisors filed in front.* Presented by Brigadier Colin Mackenzie. $G$. Ditto of New Zealander, with tattooed skin of face.

* The space filed away having been replaced by gold when originally presented, as I was informed by the late Major Kittoe. $-E$. $B$. 
J.Palmer, Esq., As. Res. XV, Appendix, p. 34.* H. Ditto of Limbu (male), -I. Ditto of Bhotiá (male), - and $J$. Ditto of Lepcha boy (14 years old). Presented by Dr. J. R. Withecombe, J. A. S. XXV, 440 (1856). $K$. Ditto of Hindu child (about 13 years old). $L$. Egyptian mummy-head of mfeale. Presented by Lt. Archbold (1844), J. A. S. VI, 322. $M$. Series of human teeth. Presented by G. Evans, Esq. (1835). N. Charred femur of a native of the Andaman Islands. Presented by Dr. Leibig, J. A. S. XXVII, 267 (1858).

\section{Fam. SIMIAD $\mathbb{E}$.}

\section{Sub-fam. SIMIANAE.}

Genus Troglodytes, Geoffroy.

2. Tr. NIGER, Geoffroy (Martin's Nat. Hist. Quad., pl. pp. $365,384)$.

Syn. Homo sylvestris, Tyson.

Troglodytes, Homo nocturnus, L., S. N., 12 th edit. Simia troglodytes, S. satyrus, et S. agrias (f. 2, a), Schreber.

S. pan, Donovan.

Pithecus leucoprymnos, Lesson.

'Chimpanzee.'

HAB. W. Africa; Sierra Leone, Guinea, Congo, Loango. $\dagger$

$A$. Stuffed specimen of a young male. Received from Mr. Bartlett (1844).

Genus Simia, L. (as restricted; Pithecus, Geoffroy).

3. S. Satyrus, L. (S. Müller, Tydsch. voor Nat., t. 1 to 7, bis.)

* This and specimens D and $\mathrm{E}$ are from the Society's old collection. In $A s$. Res. XV, App., p. 35, another "head of a New Zealander" is noticed, presented by Capt. Stead : and in Vol. XVII, App., p. 621, a "dried head of a South Sea Islander," presented by J. Burlini, Esq. : neither of these being in the museum when I took charge of it.-E. $B$.

$\dagger$ Three distinct species of Chimpanzee are now recognised. Vide Comptes Rendus, tom. XXXVI, 925, and XXXVII, 817. M. Duvernoy even considers that the great ' Gorilla' Ape (long ago indicated by Andrew Battel in Purchas's 'Pilgrims,' and doubtless identical with the Gorilloi of the Periplus Hannonis,) should be separated generically ; but few zoologists will assent to this opinion. 
Srn. S. agrias, Schreber (pl. 2, $b$ and $c$ ).

Papio Wurmbii, Latreille.

S. satyrus, Abellii, et Wurmbii, Fischer.

Satyrus rufus, Lesson.

' Orang-utan.' Orang Pandak of the Malays of Sumátra (Raffles). Mias Pappan and Mias Rambi (?) of the Dyáks of Borneo. Bán Mánus, B.

HaB. Borneo, Sumátra.

$A$. Stuffed skin of adult male, wanting the right hand and foot (which are figured in James Wilson's ' Illustrations of Zoology,' Atlas, 4to., No. IX, pls. 1 and 2). From Sumátra. Presented by Captain Cornfoot, As. Res. XV, Appendix, p. 32 (1822), and the specimen described, and its head, hand, foot, lower jaw, and teeth figured, in As. Res. XV, p. 490 , with five plates. $B$. Lower jaw of the same individual, again figured $\left(\frac{1}{2}\right.$ size) in $J . A$. S. VI, pl. 18. C. Great skull from Sumátra, figured J. A. S. XXII, 382, pls. 1 and 2. D. Skull from Borneo, ibid., pls. 3 and 4. For admeasurements, vide p. 380 . Presented by Major Gregory in 1838 (vide J. A. S. VII, 669); the Sumátran male skull, however, having been for some years reserved. N. B.-Described as Mias Rambi, and P. Brookei.

$E$. Skeleton of adult male, presented by $\mathrm{Mr}$. W. W. Nicholls of Sarawák (1853), and described $J$. $A$. S. XXII, 375-6, p. 382, pls. 5 and 6 . F. Skeleton of adult female (with supernumerary molars). Presented by Sir J. Brooke, C. B. (1855), and described $J . A$. S. XXIV, pp. 518-9. N. B.Described as Mias Pappan.

G. Skeleton of male Rambi, described J. $A$. S. XXIV, 523-4. H. Ditto, described pp. 524-5. $I$. Ditto of female, sent as Mias Chapin, and described pp. 521-2. J. Ditto, described pp. 522-3. K. Ditto, described p. 523. All from Borneo: presented by Sir J. Brooke (1855).

$L$. Skeleton of young (cutting permanent incisors, and with second upper permanent molar about to have appeared through the gum). $M$. Skull of $P$., somewhat younger (retaining deciduary incisors). IN. Ditto (first permanent molars not brought into wear). $O$. Ditto, still younger. 
$P$. A dried right hand.

Q. Extraordinary variety : described as Pithecus curTus, $J$. A. S. XXIV, 520, 525-6. Skeleton of adult male. Sir James Brooke (1855).

4. S. Morio, Owen (skull figured Trans. Zool. Soc., Vol. II, pl. 33, 34). Mias Kassar of the Dyáks of Borneo.

HAB. Borneo.

$A$. Skeleton of aged female: presented by R. W. G. Frith, Esq. (1836), vide J. A. S. XXII, 371; and skull figured p. 382, pl. 7 and 8. B. Young male. Presented by Bábu Rájendra Mállika (1859). C. Small stuffed specimen. D. Ditto of young female, described as P. Owenit in $J$. A. S. XXII, 372,375 , and skull figured p. 382 , pl. 9 and 10. $E$. Stuffed skin of $D$., perhaps of a distinct race. Presented by J. Apcar, Esq. (1846).

Remark.-The crania of Orang-utans vary to an extent unparalleled among wild mammalia: the occurrence even of supernumerary molars would appear to be not unfrequent; and, occasionally, in either sex, a well developed unguinal phalanx terminates the hallux, but does not exist in the great majority of individuals.*

\section{Sub-family HYLOBATINAE.}

Genus Hylobates, Illiger.

5. H. Hoolock (head figured badly in Martin's Nat. Hist. Quadr., p. 441).

Syn. Simia hoolock, Harlan.

S. choromandus et $H$. scyrites, Ogilby.

Hoolock, or ' White-browed Gibbon.' Utuk,

* H. Miouk-hlwai-gyau, Arakan (Phayre).

Hab. Asám, Sylhet, Arakan.

A. B. C. Males. D. E. F. Females. G. Infantile female. From Barrackpore menagerie, and presented by C. S. Bonnevie, Esq., Major Tickell, S. G. T. Heatly, Esq., and Bábu Rájendra Mállika $(1842-9)$. $\quad H$. Skeleton of $A$, adult male. $\quad I$. Ditto

* $N$. B.-In an apparently mature male, now at Burdwán, which appears to be P. Morio, there is no appearance of the cheek-callosities of P. SATYRUS. 
of $B$., sub-adult male. $J$. Skull taken from $D$.

K. Ditto of adult male. L. M. Ditto, younger.

6. H. AGILIs, F. Cuvier (Mamm. Lith. I, 2, 3 ; III, 2, 3). Srn. H. Rafflesii, Geoffroy.

H. variegatus, Müller.

Simia lar, Vigors and Horsfield.

Ungka etam, Malay; Oungka and Wouwou, F. Cuvier.

HAB. Malayan peninsula, Sumátra.

N. B.-Specimens half and one-third grown. Presented by the Máharája of Burdwán (1848).

7. H. Leuciscus.

Srn. Simia leucisca, Schreber.

S. moloch, Audebert.

Pithecus cinereus, Latreille.

The 'Wou-wou.'

HaB. Java.

$A$. Grown female, purchased (1834, and described $J . A$. S. XIII, 465). B. Skull taken from $A$.

8. H. LAR (Martin's Nat. Hist. Quadr., p. 433).

Syn. Homo lar, L.

Simia longimana, Schreber.

S. albimana, Vigors and Horsfield.

Pithecus variegatus, Geoffroy.

Hylobates entelloides, Is. Geoffroy.

' White-handed Gibbon:' Ungka itam (dark var.), and Ungka puti and Wou-wou (pale var.), of the Malays of the peninsula (Cantor).

HAB. Tenasserim provinces, Malayan peninsula.

A. B. C. D. Varieties more or less dark. E. F. G. H. Pale ditto.: Rev. J. Barbe, Rev. F. J. Lindstedt, Mr. Moxon, Major Tickell, Mr. Frith, and Mr. McClelland (1841-9). I. Skeleton of adult male, from Tenasserim, Mr. W. Theobald (1856). $J$. Skull taken from $B$. $K$. Ditto from 
pale specimen. $L$. Ditto, from pale brown specimen.*

\section{Fam. PAPIONID A.}

(Monkeys with a simple stomach and provided with cheek-pouches : peculiar to Africa and S. Asia).

Genus PaPio, Brisson, Geoffroy (nec Ogilby).

9. P. maimon (F. Cuvier, Mamm. Lith. II, 15, III, 16).

SYN. Simia maimon et $S$. mormon, $L$.

S. madaragaster, Zimmermann.

'Mandrill.'

Haв. W. Africa (within the tropics).

$A$. Stuffed male. $B$. Stuffed female. Presented by the Máharája of Burdwán (1858), J. A. S. XXVII, 273.

10. P. Leucophaus (F. Cuv., Mamm. Lith. I, 23, 24, II, 14, III, 17).

Syn. Simia leucophra, F. Cuvier.

S. cinerea et $S$. subflava, Shaw? (apud Gray).

Inuus brachyurus, Temminck.

'Drill.'

Hab. W. Africa (within the tropics).

$A$. Female. Presented by the Máharája of Burdwán (1858), J. A. S. XXVII, 273.

Genus Cynocephalus, Brisson.

11. C. PorCarius (Bennett's 'Tower Menagerie,' p. 147 ; F. Cuv., Mamm. Lith. I, 21).

SYn. Simia porcaria, Boddaërt.

S. sphingiola, Hermann.

Papio cornutus, Kuhl.

C. ursinus, Schinz.

Cape Baboon, or Chacma.

Hab. S. Africa.

$A$. Adult male, from the Cape-town museum ;

E. L. Layard, Esq. (1859). B. Stuffed

* Desid.-H. SYNDACTYLA ; Simia syndactyla, Horsfield. The 'Siamang.' Hab. Sumátra.-H. CONCOLOR, S. Müller. Hab. Borneo.-H. LEUCOGENYS, Ogilby. Hab.——? 
specimen of a young animal: purchased (1846).

Genus InuUs, Geoffroy.

12. I. SIlenus (Bennett, Gard. Zool. Soc., t. 21 ; F. Cuv., Mamm. Lith. II, 12)

SYN. Simia silenus et S. veter, L.

S. ferox et S. leonina, Shaw.

Cercopithecus senex, Zimmermann.

C. vetulus, Erxleben.

Silenus veter, Gray.

'Lion Monkey.' Nil Bándar, B. Shia Bándar, H.

Hab. Travancore and Cochin (not Ceylon), and the Malabar ghâts as high as Goa.

$A$. Large male, from Barrackpore menagerie (1843). B. Another. J. McClelland, Esq. (1848.) C. Young, purchased (1849). $D$. Skeleton of $A$.

13. I. Nemestrinus (Edw., Gleanings, t. 24 ; Buffon, Supp. VII, pl. 8 ; F. Cuv., Mamm. Lith. I, 16, II, 11).

SYN. Simia nemestrina, Desmarest.

S. carpolegus, Raffles.

S. platypygos, Schreber.

S. fusca, Shaw.

S. longicruris, Link.

Bruh, Malay. 'Pig-tailed Monkey.'

HAB. Tenasserim provinces; Malayan peninsula ; Sumátra; Borneo.

$A$. Large male. $B$. Another. $O$. Skeleton of $A$. Purchased (1843-52).

14. I. LEONINUs, Blyth, n. $s$.

Syn. Macacus nemestrinus(?), var., J. A. S. XIII, 473. I. arctoides (? Is. Geoff.) apud Blyth, J. A. S. XVI, 731. 


\section{Myouk la hoing, Arakan (Phayre). 'Long-haired Pig-tailed Monkey.'}

Hab. Arakan.

$A$. Adult male. $B$. Young. Presented by Col. Phayre (1844).

15. I. Rhesus (F. Cuv., Mamm. Lith. II, 9, 10, III, 14). Syn. Simia rhesus, Audebert.

S. erythrea, Schreber.

Pithex oinops, Hodgson.

Bánur or Bándar, B.; Murcut-Bánur (young).

Hab. Bengal; Nipal; Orissa: some districts of Central India.

$A$. Adult male. $B$. Another, younger. $C$. Another (monstrously obese). $D$. Female, with young at breast. $E$. Skeleton of male. $F$. Skull of very large male.

16. I. assamensis (?)

SYN. Macacus assamensis, McClelland, P. Z. S., 1839, p. 146.

Pithex pelops, Hodgson, J. A. S. IX, 1213 (apud Horsfield).

Haв. Sub-Himalayan region; Asám.

$A$. Specimen presented by the Máharája of Burdwán (1848), J. A.S. XXVII, 273.*

Genus Macacus, Lacépéde.

17. M. Radiatus (affinis).

Нав. Formosa (camphor forests of the interior).

$A$. Skull of a young animal, from Formosa. Presented by R. Swinhoe, Esq. (1859), J. A. S. XXIX, 87.

18. M. Radiatus (Bennett's 'Tower Menagerie,' p. 147 ; F. Cuv., Mamm. Lith. I, 13).

* Desid.-I. ARCTOIDES ; Macacus arctoides, Geoffroy, Zoologie du Voyage de M. Belanger. 
SYn. Cercopithecus radiatus, Kuhl.

'Toque,' or ' Bonnet Monkey.' 'Koti, also Mungya and Munga, Kan.;' Bándar, Dukhuni ; Makorda, Mahratta; Kerda, ditto of the ghâts (Elliot). Vella Munthi, Malayálum.

HaB. Peninsula of India, northward to the Godavery on the Coromandel side.

A. Half-grown. Purchased (1844).

19. M. pileatus (Buffon, Nat. Hist. XIV, 30).

SYn. Simia pileata, Shaw.

S. sineca, L.

Cynocephalus sinensis, Latreille.

'Chinese-bonnet Monkey;' Raláwa, Cingh.

Hab. Ceylon (not China).

A. Adult male. R. Templeton, Esq. (1848). $B$.

Young ditto (1848). C. D. Imperfect skulls. Mr. Layard.

20. M. cynomolgos (Buffon, Nat. Hist. XIV, 13 and 21;

F. Cuv., Mamm. Lith. I, 11, 12).

Srn. Simia cynomolgos et aigula, L.

S. fasciculata, Raffles.

S. attys, Schreber.
'Common Macaque;' Krá, Malay.

HAB. Burmese countries, Nicobar Islands, Malayan peninsula, Sumátra, Jáva, Borneo, Celebes, Timor, Mauritius (hodiè).

$A$. Old male, purchased (1844). B. Young, from Nicobars. Capt. Lewis (1846). C. Young, from Timor. Mr. Benson (1846). D. Skull of old male. $\quad \boldsymbol{E}$. Ditto, younger male.

21. M. Carbonarius, F. Cuvier (Mamm. Lith. III, 12coloring too pale). J.A.S. XIII, 474.

SYn. M. auratus, Is. Geoffroy (golden-rufous variety).

Myoûk ta-nga, Arakan (Phayre).

Hab. Arakan, Pegu.

A. Adult male, purchased (1844). B. Young. Captain Abbott (1844). C. Much injured skin of 
young (rufous variety). Mergui, Major Berdmore (1854). D. E. Skulls. Colonel Phayre (1843).

Genus Cercopithecus, Erxleben.

22. C. SABæús (Edwards's 'Gleanings,' t. 215 ; Bennett, Gard. Men. Z. Soc. I, 303 ; F. Cuv., Mamm. Lith. I, 10).

Srn. Simia saboea $L$.

C. viridis, Hermann.

C. chrysurus, nobis, J. A. S. XIII, 477.

'Green Monkey.'

Hab. Cape de Verd Islands; W. Africa.

A. Large male. C. C. Egerton, Esq. (1836, J. A. S. V, 191). B. Young, from the Cape de Verds: purchased (1847). C. Skull of $A$.

23. C. Faunus.

Srn. Simia faunus, L.

S. cynosurus, Scopoli, Kuhl, and Geoffroy.

HАв. Guinea.

$A$. Adult male, presented by Bábu Rájendra Mállika (1857).

24. C. engrthithia (F. Cuvier, Mamm. Lith. I, 9).

Syn. Simia engythithia, Hermann.

C. griseo-viridis, Desmarest.

C. cano-viridis, Rüppell.

C. sub-viridis, F. Cuvier (apud Gray).

C. cinereo-viridis, Temminck.

'Grivet Monkey.'

Haв. Abyssinia.

$A$. Specimen presented by Dr. E. Rüppell (1856).

25. C. Monordes (Comptes Rendus XV, 1038 ; Archives des Musée II, pl. 3 ; apud Schinz).

Hab. Africa.

A. Young. Presented by Bábu Rájendra Mállika (1853). 
26. C. ruber (F. Cuvier, Mamm. Lith. III, 10; Bennett, Gard. Mem. Z. Soc. I, 135).

Syn. Simia rubra, Gmelin.

S. patas et S. rufa, Schreber.

S. pyrrhonotus, Ehrenberg.

'Red Monkey;' Patas, or Nisnas.

HAB. Senegal, Ethiopia.

A. Skull. B. Portion of skin. Mr. Bartlett (1844).

Fam. COLOBID RE.

(Monkeys with a sacculated stomach and unprovided with cheek-pouches: peculiar to Africa and S. Asia).

Genus Presbytis, Illiger.

27. Pr. entellus (F. Cuvier, Mamm. Lith. I, 3, III, 6 ; Bennett, Gard. Mem. Z. Soc. I, 81).

Srn. Simia entellus, Dufresnoy.

\section{Hunumán, B.}

Haв. Bengal, Orissa, Asám, Upper Hindustán, C. India, rare (and local ?) in S. India. Dukhun?

A. Adult male. B. Adult female. Procured by the Curator (1842). C. Adult female, lowerparts deeply tinged with rusty-fulvous. From Junghypur. J. Laidlay, Esq. (1848). D. E. Young. Procured by the Curator. $F$. Skeleton of adult male. G. II. I. Skulls. J. Variety? Pr. anclises, Elliot, J. A. S. XIII, 470, X VI, 733. A skin. Walter Elliot, Esq. (1847).

28. Pr. schistaceus, Hodgson, J. A. S. IX, 1212.

Syn. Himaláyan Pr. entellus, auctorum.

\section{Lángûr, $\mathrm{H}$.}

HAB. Himaláya; Kaffiristân? (J.A. S. XXVIII, $332)$.

A. Adult male. Presented by Capt. T. Hutton (1848). B. Skull. Presented by L. C. Stewart, Esq. (1854). Both from vicinity of Másuri. 
29. Pr. JohniI.

Syn. Simia Johnii, Fischer.

S. Johnii, var., Martin.

Semnopithecus hypoleucos, Blyth, J. A. S. X, 839.

S. Dussumieri, Is. Geoffroy.

HAB. Malabar Ghâts, Travancore.

A. Male, from Travancore. Presented by Dr. W. Coles of Madras (1841).

30. Pr. priamus, Elliot, $J$. A. S. XIII, 470.

Syn. Pr. entellus of S. India, auctorum.

Musia, Kan.; Langûr, Dekháni ; Wánur, Mahratta (Elliot); Mákur, Mahratta (Sykes); Walla Munthee, Malayálum; Sadu Wanderu, Cingh.

Hab. Peninsula of India and Ceylon; ranging northward to the Godaveri. (Of darker color in Ceylon.)

A. Female, from S. India. Presented by W. Elliot, Esq. (1847). B. Specimen from Pt. Pedro, Ceylon; very dark in coloring. E. L. Layard, Esq. (1848). C. Adult male, similar, but larger, and no crest on vertex; the original of $P$. thersites, Elliot, from Ceylon. Presented alive by W. Elliot, Esq. (1845). D. Another from Ceylon, dark and crested. E. L. Layard, Esq. (1849). $E$. $F$. Skulls from Trincomali. Dr. E. F. Kelaart. G. H. Skulls, also from Ceylon. E. L. Layard, Esq.

31 Pr. pileatus, nobis, J. A. S. XII, 174; XIII, 467 ; XVI, 735 .

Hab. Nágas, and hill regions of Sylhet, Tipperá, Chittagong.

$A$. B. Adult male and female, from the interior of the Chittagong hills. Rev. J. Barbe (1844). 
C. Male, from Tipperá hills. F. Skipwith, Esq. (1846). D. Female, from Barrackpore menagerie (1843).

32. Pr. maurus (S. Müller, Tydsch. voor Nat., t. XII, bis, f. 3, - the head only; F. Cuv., Mamm. Lith. II, 5).

Syn. Simia maura, Schreber (nec Raffles).

Semnopithecus pyrrhus (?), Horsfield; rufous variety?

Budeng of eastern districts of Java; Qutung of western (Horsfield).

(Obs.-The " middle-sized Black Monkey" of Edwards, pl. 311 (Simia Edwardsii, Fischer), cannot be intended for the present species, to which it has been assigned, since, being drawn from life, it does not represent the long hair of the crown parted on either side, which is characteristic, and far too conspicuous a feature to have been overlooked).

$A$. Male. B. Female : purchased (1846-9). $C$. Skeleton of female.

33. Pr. ursinus, nobis, J. A. S. XX, 155.

Haв. Mountainous regions of Ceylon.

$A$. Adult male. B. Half-grown specimen.

C. Small young. Presented by Dr. E. F. Kelaart (1847).

34. Pr. cephalopterus (Buffon, Nat. Hist., Supp., VII, t. 21).

Syn. Cercopithecus cephalopterus, Zimmerman.

C. latibarbatus, Geoffroy.

C. leucoprymnos, Otto.

Simia dentata, Shaw.

S'emnopithecus fulvogriseus, Desmoulins.

Semn. nestor, Bennett.

Semn. porphyrops, Link.

Presbytis albinus, Kelaart, J. A. S. XX, 182.

Kálu Wandera, Cingh.

Hab. Ceylon.

A. Female, purchased (1845): black, slightly grizzled, with contrasting brown crown and white 
whiskers; rump and outside of thighs whitish, and base of thighs white internally. B. Another female; brown, with paler brown crown. E. L. Layard, Esq. (1848). C. Another female, of a more rufous brown. Presented by T. C. Jerdon, Esq. (1843). D. Another female, almost wholly white, save on the crown, nape, and a partial admixture of dusky hairs on the back. Presented by Dr. E. F. Kelaart (1851). E. Skeleton of female. F. Skull.

35. Pr. Cucullatus (Schreber's Supp., $1855 t$. ).

Srn. Semnopithecus cucullatus, Is. Geoffroy.

S. jubatus, Wagner.

S. Johnii apud Martin, and J. A. S. XIII, 469, and XVI, 734.

Hab. Nilgiris, Pulneys, and Malabar Ghâts.

$A$. Adult male, received dead from Barrackpore (1844). B. Female, from Nilgiris, with very long hair on head. T. C. Jerdon, Esq. (1843).

36. Pr. Barber, Blyth, J. A. S. XVI, 734.

HAB. Interior of Tippera hills.*

(Obs.-Probably identical with Pr. Femoralis, (Horsfield,-chrysomelas, S. Müller, Tydsch. voor Nat., t. 10), but the sexes are equally dark; and of two specimens, one only has a little white at base of thigh underneath, and more on one side than on the other. From the two following species, it differs in having the face black and the occipital hair comparatively short and scarcely paled, as so conspicuously in Pr. obscurus.)

A. B. Male and female. Presented by the Rev. J. Barbe (1845).

37. Pr. obscurus.

SrN. Semnopitinecus obscurus, Reid.

S. leucomystax, Temminck.

S. sumatranus, Müller (apud Schinz).

S. halonifer, Cantor.

Lotong, or Lotong-itam, of the Malays of the peninsula.

* According to information subsequently reeeived from M. Barbe. 
Ha b. Malayan peninsula, Mergui.

A. Adult male. Rev. F. W. Lindstedt (1846). $B$. Adult female. Mr. Frith (1846). C. Halfgrown; pale. Mr. Moxon (1856). D. E. F. Young: wholly golden-rufous,_-varied,-and dark, with only tail rufous. Rev. F. W. Lindstedt and Mr. Frith. All from Malacca. $G$. Flat skin of young; coloring mixed: from Mergui. Major Berdmore (1854). H. Skeleton of 'Negro Monkey' (maurus apud Pearson), J. A. S. VII, 669; but probably appertaining to the present species. Dr. Helfer (1838).

38. Ph. Phayrei, Blyth, J. A. S. XVI, 733.

Syn. Semnopithecus argentatus, Blyth, MS. (Horsfield's Catalogue).

$\mathrm{H}_{\mathrm{AB}}$. Arakan.

$A$. Adult male, with $B$. its skull. Colonel Phayre (1844). C. D. Young. Major Abbott (1844).

39. Pr. albocinereus, J. A. S. XV, 733.

Syn. Cercopithecus albocinereus, Desmarest.

Semnopithecus dorsatus, Waterhouse (apud Cantor), the young.

$P r$. cinerea, Gray.

Kákâa of the Malays of the peninsula.

Hab. Malayan peninsula.

$A$. Male. R. W. G. Frith, Esq. (1846). $B$. Female. Rev. F. W. Lindstedt (1846). C. Another female, palish. D. Young. Mr. Frith. All from Malacca.*

* Desid.-Pr. Potenziani ; Semnopithecus Potenziani, Pr. Bonap, Comptes Rendus, tom. XIIII, p. ${ }^{4} 412$. Hab. Tenasserim provinees ; and distinguished by the "brilliant golden tint of the belly."

Pr. cristatus; Simia cristata, Raffles; Semnopithecus pruinosus, Desmarest. 'The 'Chingkau.' Hab. Malayan Peninsula, Sumátra, Borneo, and Banka.

N. $B$.-A stuffed specimen of the 'Simpai,' Semn. melatophos, is stated to have been in the museum in $J . A . S . \mathrm{X}, 661$ : but a half-grown Pr. entelus was the only example of this genus in the museum at the time of my taking charge; besides the skeleton, No. $37, \mathrm{H},-E . B$. 
Sub-tribe. Platyrrhini.

Fam. CEBID A.

Genus Chrysothrix, Wagler.

40. Chr. sciureus (Buffon, Nat. Hist. XV, 51; Wagler, Saugth., Supp., 1855, t. 9; F. Cuv., Mamm. Lith. I, 33).

Syn. Simia sciurea, L.

Lemur leucopsis, Hermann (apud Gray).

'Squirrel Monkey ;' Saimiri, Buffon.

HaB. Brazil.

A. Stuffed specimen. B. Skull. Mr. Bartlett (1844).

Genus $J_{\text {ACCHUS, Geoffroy. }}$

41. J. vUlgaris, Geoffroy (Buffon, Nat. Hist. XV, 14; Edwards's ' Gleanings,' pl. 218; F. Cuv., Mamm.

Lith. I, 34, 35).

Syn. Simia jacchus, L.

' Common Marmozet ;' Oustiti.'

HАв. Brazil, Guiána.

A. Male. Mr. Bartlett (1844). B. Another. Presented by the Curator (1851). C. Skeleton of female. Presented by the Curator (1852). $D$. Skull of $A$. E. F. Young in spirit, born in Calcutta. Presented by the Curator (1851).

Tribe Lemuria.

Sub-tribe Strepsirhini.

Fam. LEMURID E.

Sub-fam. LEMURINAE.

Genus Lemur, L.

42. L. MACẢCO, L. (Buffon, Nat. Hist. XIII, 29.)

'Ruffed Lemur.' 
F. Cuv. Mamm, Lith. III, 23.)

HAB. Madagascar.

$A$. Stuffed specimen: Society's old collection, $B$. Skull, toothless (noticed $J$. A.S. IX, 526), and here adjudged to belong to this species.

43. L. Nigrifrons (Bennett, Gard. Z. S. p. 301 ; F. Cuv. Mamm. Lith. II, $t$. 19.)

Syn. L. simia-sciurus, Schreber (apud Gray).

' Black-fronted Lemur.'

Hab. Madagascar.

$A$. Specimen presented by Bábu Rájendra Mállika (1851). $B$. Skeleton of the same individual.

44. L. Albifrons, Geoffioy (F. Cuv. Mamm. Lith. I, 40 and 41).

Hab. Madagascar.

' White-fronted Lemur.'

$A$. Male presented by the Máharája of Burdwán (1858), J. A. S. XXVII, $273 . \quad B$. Female ( $L$. flaviventer, Lesson, apud nos, J. A. S. XXVII, 274 ; F. Cuv. Mamm. Lith. I, t. 41). Presented by do.

45. L. NIGER, Geoffroy (Edwards's 'Gleanings,' pl. 217).

Syn. L. macaco, Shaw.

'Black Lemur.'

HAB. Madagascar.

A. Specimen presented by Bábu Rájendra Mállika (1850): tail imperfect.

46. L. Catta, L. (Edw. Gl., pl. 197 ; Buffon, N. H. XIII, t. 22 ; F. Cuv. Mamm. Lith. I, t. 38).

'Ring-tailed Lemur.'

HAB. Madagascar.

$A$. Specimen presented by Dr. E. F. Kelaart (1852). 
Genus Nycticebus, Geoffroy.

47. N. Tardigradus (F. Cuv. Mamm. Lith. II, 20).

Syn. Lemur tardigradus et $N$. javanicus, Geoffroy.

Stenops javanicus et St. tardigradus, Van der Höeven.

Shirmindi Billi, and Lajja Bánur, H. ; Kakang, Malay, and a larger variety-BruhSamúndi, (Raffles); Tukang, Jav. 'Sloth' of Europeans in India;" or, better, "Slow Loris.'

Hab. Eastern Bengal, Sylhet, Asám, and eastern shores of the Bay of Bengal to Malayan peninsula, Sumátra, Jáva, and Borneo ; Siam.

A. Variety (?) inhabiting Bengal and Asám, southward to Tenasserim; two upper incisors only: general color pale, with no distinct dark stripes on forehead and temples.

$A$. Adult, and $B$. Young: from Tippera. F. Skipwith, Esq. (1846). C. Skull.

B. Malayan peninsula variety. (?) with four upper incisors; the fur deeper in coloring, and no defined dark markings upon the head.

$D$. Adult. $E$. Smaller, from Malacca. Rev. F. J. Lindstedt (1846). F. Another. Mr. Bell (1857), J. A. S. VI, 240. G. Skull of $E$. H. Skull of $F$.

C. Javanese variety (?) with two upper incisors only; and five well defined broad dark stripes meeting towards the occiput, one from each eye, another from each ear, and the fifth continued to form the medial dorsal streak.

I. Adult, from Java. Presented by the Batavian Society (1845).

N. B.-These races need further investigation; and Bennett's figure (Gard. and Menag. $Z$. Soc. I, 139), cannot well be referred to either of them.

* " Little Bradypus" of Helfer ! J. A. S. VII, 859. 
Genus Loris, Schreber.

48. L. GRaCILIS, Geoffroy (Buffon, Hist. Nat. XIII, $t .30$; Tennent's ' Ceylon', 1, 134).

Syn. Lemur loris, Shaw.

Loris ceylonicus, Fischer.

L. macauco, Pennant.

Seyvangoo, Malays in Ceylon; Onahappoolowa, Cingh.

'Slender Loris.'

Hab. Coromandel Coast, Malabar, Ceylon (a black variety in Ceylon, Sir J. E. Tennent).

$A$. B. Specimens from Coromandel, and $C$. Skeleton. W. Elliot, Esq. (1843). D. Shorterlimbed specimen, noticed $J . A$. S. XVI, 736. $E$. Skull of ditto. Presented by Dr. A. Webb, on the part of the Medical College (1844).

\section{Fam. GALEOPITHECID $\not E$.}

Genus Galeopithecus, Pallas.

49. G. volans (good figure in 'Penny Cyclopædia,' art. Pleuroptera).

SYN. Lemur volans, L.

Vespertilio admirabilis, Bontius.

G. rufus, variegatus, undatus, marmoratus, Temminckii, (nec PHILIPPINensis,) auctorum.

Kábong or Kurbong, Malay; Gendu, Jav.

HAв. Mergui, Siam, Malayan peninsula, Sumátra, Jáva, Borneo: (the Philippine species distinct).

A. B. Specimens from Malacca; presented by R. W. G. Frith and C. Huffnagle, Esqrs. (1844). C. D. E. F. Skulls, varying remarkably in the degree of approximation of the teeth; all from Malacca. 
Sub-order CHEIROPTERA.

Tribe Harpydia.

Fam. PTEROPODID AE.

Genus Pteropus, Brisson.

50. Pt. Poliocephalus, Temminck (Gould, Monogr. Austr. Mamm. pl. ).

Нав. Australia.

$A$. Specimen presented by the Sydney Institution (1846).

51. Pr. Edwardsir (Geoffroy, Edwards's ‘ Birds,' pl. 180). Srn. Pt. medius, Temminck.

Pt. leucocephalus, Hodgson.

Pt. assamensis, McClelland.

Búduls-B.: Páta Debli, H.: Warbagúl, Mahr. (Sykes); Gaddal and Barbagul, Dukhuni (Elliot); Toggal Báwali, Can.; and Sikatyette, ditto, Wuddur caste (Elliot): Waola, Cingh,-Wawul, Malays of Ceylon (Kelaart).

HAB. India generally; Ceylon; Maldives and Laccadives; Asám ; Sylhet; Arakan; Pegu; Tenasserim; Malayan peninsula (?)

$A$. to $H$. Specimens from vicinity of Calcutta (1842-3). I. Ditto, Mergui, Major Berdmore (1855). J. Skeleton (1810).

52. Pт. melanotus, nobis, $n$. $s$.

HaB. Nicobar Islands.

$A$. B. Specimens presented by Capt. Lewis (1846).

53. Pт. edulis, Peron and Lesueur (Horsf. Zool. Res. in Java, pl. ).

SYv. Pt. javanicus, Desmarest.

$\left.\begin{array}{l}\text { Vespertilio vampyrus, L. } \\ \text { V. coelono, Hermann. }\end{array}\right\}$ apud Gray.

Kalong, Java; Kluang, Malay (Cantor). 
HAB. Malay countries.

A. B. C. Specimens from Java, presented by the Batavian Society (1845). D. Bad skin, from Tenasserim, Dr. Helfer (1839).

54. Pt. Leschenaultir, Desmarest.

Hab. S. India, Ceylon.

A. Specimen from Coromandel coast (Carnatic?). Walter Elliot, Esq. (1846). B. Ditto from Ceylon. $J . A$. S. XX, $155 . \quad C . D$. Old and younger males in spirit, from Ceylon. Dr. Kelaart (1851).

Genus Xantharpyia, Gray.

55. X. amplexicaudata (Ann. Mus. XV, 7; Tem. Monagr., I, 13).

Syn. Pteropus amplexicaudatus, Geoffroy.

HAb. Malay countries; Siam (nec India.) (1845).

56. X. hottentota.

Srn. Pteropus hottentotus, Temminck.

HАB. S. Africa.

A. Specimen presented by E. L. Layard, Esq. (1859).

Genus Macroglossus, F. Cuvier.

57. M. minimus (Horsf. Zool. Res. in Java, pl. ; F. Cuv., Mamm. Lith. II, t. 23).

Syn. Pteropus minimus, Geoffroy.

$P l$. rostratus, Horsfield. Jowo-assu ('Dog-bat'), Java. *

Hab. Burma, Siam, Malay countries.

$A$. Specimen in spirit, from the valley of the Sitang river, Tenasserim provinces. Presented by Major Berdmore (1858), J. A. S. XXVII, 293.

* The French name Kiodote, remarks Dr. Horsfield, which is commonly applied to this species, " appears to be a perversion of the name Chodot, applied by the Javanese to several small Cheiroptera.". 
Genus Cynopterus, F. Cuvier.

58. C. marginatus.

SYN. Vespertilio marginatus, B. Hamilton.

Pteropus et Pachysoma titthcecheilus, Temminck. Pachysoma brevicaudata, P. Diardii, et P. Duvaucelii, F. Cuvier.

Pteropus pyrivorus, Hodgson.

Pt. Dussumieri (?), Royle's Catálogue.

Cynopterus Horsfieldii* et C. affinis (?), $\uparrow$ Gray. Chám Gudili, B.

HАB. India generally; Ceylon; Burmese and Malay countries; Nicobar islands.

$A$. to $I$. Series of nine specimens illustrative of variation, from vicinity of Calcutta (1841-51). J. Bottle of ditto, Calcutta. K. Ditto, ditto, Ceylon. Dr. Kelaart. L. M. Stuffed specimens, from Malacca. N. O.P. Ditto, from Java. Batavian Society (1845). M. N. Skeletons. Calcutta.

\section{Tribe SPECTRA.}

Fam. VAMPYRIDA.

Sub-fam. MEGADERMATINAE.

Genus Megaderma, Geoffroy.

59. M. LYRA, Geoffroy (Ann. Mus. XV, 12), J. A. S. XI, 255, 600, and XIII, 480.

Srn. M. carnatica, Elliot.

M. schistacea, Hodgson.

HAB. India generally; Ceylon.

A.B. C. D. Stuffed specimens from vicinity of Calcutta. E. Ditto. Ceylon. Dr. Kelaart (1852). F. G. H. Specimens in spirit. I. J. Skeletons; one presented by Mr. W. Masters (1842).

* Neck and sides very bright rufous, as in $C$. $D$., from vicinity of Calcutta.

$\dagger$ From Himalaya : undescribed. Gray's Catalogue. 
60. M. Horsfieldi, nobis, $n$. $s$.

Srn. Megaderma, No. 39 of Horsfield's Catalogue.

M. spasma apud nos, J. A. S. XXIV, 711.

HAB. Tenasserim provinces.

$A$. B. Specimens in spirit. Tenasserim. W. Theobald, Esq., Jun. (1855).

61. M. spasma (Ann. Mus. XV, 12).

Srn. Vespertilio spasma, L.

M. trifolium, Geoffroy.

Hab. Malayan peninsula and archipelago. Ceylon.*

$A$. Specimen from Java. Presented by the Batavian Society (1845). B. C. Ditto, from Malacca. Mr. G. Moxon (1850).

Sub-fam. RHINOLOPHINAE.

Genus Rhinolophius, Geoffroy.

62. Rh. Perniger, Hodgson, J. A. S. XII, 414, XIII, $484 . \dagger$

Hab. Nipâl ; Sikhim; Kás'hia hills. "Central region of the Sub-Himaláyas" (Hodgson).

$A$. Specimen from Dorjiling. Major W. S. Sherwill (1852). $B$. Skull of $A$. C. Skeleton, from specimen presented by B. H. Hodgson, Esq. $(1842)$.

63. Rh. mitratus, nobis, J.A.S. XIII, 483 ; XXII, 409.

Hab. Central India.

A. B. Specimens from Chaibása. Major S. R. Tickell (1843).

* The Ceylon specimens noted J.A.S. XXI, 346, have disappeared from the museum.

$\dagger$ This closely approaches RH. Luctus, Tem., but would appear to differ in having less complicated facial membranes. Vide also RH. morio, Gray, Ann. $M$. N. H., X (1842), 257, which is probably identical with RH. LUCTUS. (J. A. S. XXI, 347.) 
64. Rh. Pearsoni, Horsfield, Catal. ; J. A.S. XXII, 409.

НАв. Sikhim.

$A$. Specimen in spirit. Presented by Major W. S. Sherwill (1853).

65. Rh. brevitarsus, nobis, $n$. $s$.

Haв. Sikhim.

$A$. Specimen from the vicinity of Dorjiling. Presented by W. T. Blanford, Esq. (1857).

66. Rh. tragatus, Hodgson, J. A.S. IV, 699 ; XIII, 484.

HАв. Himaláya.

A. B. Specimens in spirit ; from Nipâl. B. H. Hodgson, Esq. (1843). C. D. Ditto from Másuri; Capt. T. Hutton (1852).

67. Rh. affinis, Horsfield, Tem. (nec apud Cantor).*

Syx. Var. Rh. rubidus, Rh. fulvidus, et $R$. cinerascens, Kelaart, of Ceylon.

HAB. Malay countries; Tenasserim provinces; Ceylon. S. Malabar.

$A$. to $G$. Stuffed specimens, varying from bright rufous to dusky brown. $H$. Four specimens in spirit ; Ceylon. Dr. Kelaart (1852). I. J. Two specimens in spirit from the valley of the Sitang river. Presented by Major Berdmore (1858-59).

68. RH. Rouxi, Temminck.

Srn. Rh. lepidus, nobis, $J . A$. S. XIII, 486.

Rh. minor (?) apud nos, $J$. A. S. XXI, 486.

H. rammanika (?), Kelaart, of Ceylon.

* In Dr. Cantor's specimens the tail measures only $\frac{1}{2}$ inch to $\frac{5}{8}$ inch. In these here referred to RH. AFFINIs, the tail measures 1 inch. 
HAB. Bengal; Upper and S. India, Másuri. China (Amoy).

A. B. C. Stuffed specimens, from Barrackpore. Major R. C. Tytler (1852-60). B. Specimen in spirit, from Patargháta, near Colgong. W. Theobald, Esq. (1856), J.A.S. XIX, 561.* C. Do. from Amoy. R. Swinhoe, Esq. (1860).

69. RH. subbadius, Hodgson, $J$. A. S. XIII, 486.

Hab. Nipâl.

A. Specimen presented by B. H. Hodgson, Esq. $(1832)$.

70. Rh. MaCrotis, Hodgson, J. A. S. XIII, 485.

HAB. Himaláya.

$A$. Specimens in spirit, from Nipál. Rufous, B. H. Hodgson, Esq. (1842). B. Ditto, brown. Másuri, Capt. T. Hutton (1852).

72. Rh. FerRum-Equinum (Bell's Brit. Quad., pl. ). Syn. Vespertilio ferrum-equinum, Schreber.

V. hippocrepis, Pallas.

Rh. unihastatus, Geoffroy.

НАв. Europe.

A. Stuffed specimen, from France. M. Maleherbe (1856).

73. Rh. Hipposideros, Geoffroy (Bell's Brit. Quadr. pl. $\quad$; F. Cuv., Mamm. Lith., II, t. 24).

Syr. Rh. bihastatus, Geoffroy.

Rh. hippocrepis, Hermann.

Нав. Europe.

$A$. Skull of a specimen presented by H. E. Strickland, Esq. (1846).

Genus Hipposideros, Gray.

74. H. ARMIGER.

Syn. Rhinolophus armiger, Hodgson, J. A. S. IV, 699.

Hab. Himalaya.

* A bottle containing numerous examples of this species has been abstracted. $-E . B$. 
A. Large male in spirit, with frontal pore greatly developed. B. Female, stuffed. Dorjiling. Presented by Major W. S. Sherwill (1852).

75. H. LanKadiva, Kelaart, Prod. Faun. Zeyl., p. 19 ; J. A. S. XX, 183.

Syn. Rhinolophus insignis of Ceylon, apud Waterhouse?

$\mathrm{H}_{\mathrm{AB}}$. Ceylon. Very abundant about Kandy.

$A$. Adult male in spirit, having no frontal pore but merely a slight depression in its place, on either side of which is a wart-like tubercle. $B$. Female in spirit. C. Another female, stuffed. Presented by Dr. E. F. Kelaart (1852). D. Skeleton.

N. B.-This fine species approximates H. DIADEMA, (Geoff.), but the uppermost transverse crest is trilobate, the medial lobe small, presenting an appearance which might well have suggested the appellation diadema.

76. H. NobILIs (Horsf. Zool. Res. in Java, pl. ; Tem., Mon. II, pl. XXII).

Syn. Rhinolophus nobilis, Horsfield.

HaB. Burmese and Malayan countries.

A. Specimen from Maulmein. Presented by Major S. R. Tickell (1858).

77. H. Larvatus (Horsf. Zool. Res. in Java, pl. ).

Syx. Rhinolophus larvatus, Horsfield.

H. vulgaris apud nos, J. A. S. XIII, 488.

H. aureus (?), Kelaart, from Ceylon, Prod. Faun. Zeyl., p. 18.

Hab. Sylhet, Arakan, Java.

A. B. C. Specimens from Arakan. Presented by Col. Phayre (1842). D. E. F. G. Ditto from Sylhet. Presented by F. Skipwith, Esq., c. s. (1853); J. A. S. XXंI, 416. Colour varying from bright orange-fulvous to dark brown.

78. H. SPEORIS.

Srn. Vespertilio speoris, Schn. (nec Geoffroy).

Rhinolophus dukhunensis, Sykes. 
$H$. apiculatus et $H$. penicillatus, Gray.

$\boldsymbol{H}$. speoris et $\boldsymbol{H}$. Templetonii (?), Kelaart, of Ceylon.

Rh. voulha, Templeton, of Ceylon.

HAB. S. India, Deyra Doon, Ceylon. (N. B.-The races from these different localities may yet prove to be distinct, however closely affined.)

$\dot{A}$. $B$. Specimens in spirit. $C$. Stuffed specimen. Presented by W. Elliot, Ešq. (1842). D. E. F. G. $H$. Stuffed specimens from Ceylon, varying in hue from bright rufous to dark. I. Bottle of ditto in spirit. Presented by Dr. E. F. Kelaart (1852). J. Specimen from the Deyra Doon. Presented by L. C. Stewart, Esq. (1854). $K$. Skull of Dukhun specimen.

79. H. cineraceus, nobis, J. A. S. XXII, 410.

HAB: Pánjáb salt range.

$A$. Stuffed specimen. $B$. Two examples in spirit. From Pind Dádun Khán. Presented by W. Theobald, Esq., Jun. (1853-4).

80. H. MURINUS.

SYN. Rhinolophus murinus, Elliot.

Var. H. fulvus, Gray, et

H. fulgens, Elliot.

Var. Rhinolophus ater, Templeton, et

H. atratus, Kelaart.

HAB. S. India, Ceylon, Tenasserim, Malayan peninsula, Nicobar islands.

A. Specimen in spirit. Tenasserim. Mr. Theobald (1855). B. Bottle of ditto (var. ater), from Ceylon. Presented by Dr: E. F. Kelaart (1852).

Genus Carops, Blyth.

81. C. Frithil, nobis, J. A. S. XVII, 251, XXI, 361.

HAB. Bengal Sundarbáns.

$A$. Specimen (as yet unique). Presented by $\mathbf{R}$. W. G. Frith, Esq. (1846). 
Genus Nycteris; Geoffroy.

82. N. JaVanica, Geoffroy (Ann. Mus. XX, t. 1).

Srn. N. Kuhlii, Temminck.

Petalia javanica, Gray.

HAB. Malay countries.

$A$. Specimen from Java. Presented by the Batavian Society (1846). B. Ditto from Malacca. W. G. Moxon (1851).

Genus Rhinopoma, Geoffroy.

83. RH. Hardwickir, Gray, J. A. S. XIII, 492.

HAB. Hindustan, Indian peninsula, Malayan peninsula.

A. B. Specimens in spirit. C. D. Stuffed. Agra, Major R. Wroughton (1844). E. Another, stuffed, the supposed African specimen from Mr. Bartlett, noticed loc. cit. $F$. Skeleton.

Fam. NOCTILIONID AE.

Sub-fam. TAPHOZOINAE.

Genus Taphozous, Geoffroy.

84. T. SaCColatmus, Temminck (Mon. Mamm. II, $t$. LX, figs. 1 to 6.$)$

Syn. T. pulcher, Elliot, J. A. S. XIII, 492.

T. crassus, nobis, J. A. S. XIII, 491, XXI, 348.

HАв. Hindustan, Indian peninsula, Malayan peninsula, Java.

$A$. Stuffed specimen (T. pulcher). Presented by the Hon'ble W. Elliot (1843). $B$. Ditto from Java. From the Batavian. Society (1845). C. Example in spirit, from Mirzapore. Presented by Major R. Wroughton (1844). D. $E$.' Others in spirit. Tenasserim. Mr. Theobald (1855), J. A. S. XXIV, 711. 
85. T. Longimanus, J. A: S: X, 974, XIII, 490.

Srn. Vespertilio longimanus, Hardwicke, Lin. $T r$. XIV, 17.

T. fulvidus, nobis, J. A. S., X, 975. J. A.S.

$\left.\begin{array}{l}\text { T. brevicaudus, nobis, ibid, } 976 . \\ \text { T. Cantori, nobis, ibid. XI, 784. }\end{array}\right\} \mathrm{XXI}, 348$.

HAB. India generally, Ceylon, Burmese countries.

A. B. C. D. E. F. Stuffed specimens, Calcutta. $G$. Bottle of entire specimens, some from Rangoon. Presented by Dr. Fayrer, J. $A$. $S$. XXII, 414 (1852). H. I. Skins (not in good condition), from Ceylon. Dr. E. F. Kelaart. Ditto, Travancore (T. brevicaudus). Presented by Dr. Coles (1841). K. L. Fulvescent variety (T. fulvidus), Calcutta. M. Skeleton.*

N. B.-This species is pale fulvescent when young, and becomes gradually blacker with' age; the very old being somewhat of a deep black.

Sub-fam. NOCTILIONINAE.

Genus Cheiromeles, Horsfield.

86. Сh. torquatus, Horsfield, (Zool. Res. in Java, $t$. ; Tem. Mon. Mamm. I, t. 17).

SyN. Molossus torquatus, Fischer.

Dysopes cheiropus, Temminck.

HAB. Sumatra, Java, Borneo, Siam? CochinChina?

A. Stuffed specimen, from the Batavian Society (1845).

Genus Nyctinomus, Geoffroy.

87. N. Insignis, Blyth, J. A. S. XXIX,

HAB. China.

$A$. Specimen from Amoy. Presented by $\mathrm{R}$. Swinhoe, Esq. (1860).

88. N. Plicatus (Lin. Trans. V, II, 18).

Srn. Vespertilio plicätus, Buchanan Hamilton.

Nyct. bengalensis, Geoffroy.

* Desid. T. melanopogon, Tem. Hab. Indian peninsula, Malayan peninsula, Java. 
$N$. dilatatus, Horsfield.

Var. N. tenuis, Horsfield.

HAB. Hindustan, Bengal ; and darker variety (N. tenuis) in Malay countries.

A. B. Stuffed specimens. "Ludiana." Capt. Boys (1845). C. D. Ditto. Calcutta. E. F. Examples in spirit. Calcutta. $G$. Skeleton. $H$. Dark specimen (N. tenuis), old collection.

Fam. VESPERTILIONIDAE.

Sub-fam. SCOTOPHILINAE.

Genus Noctulinia, Gray.

89. N. NOCTULA.

Srn. Vespertilio noctula et lasiopterus, Schreber.

V. serotinus apud Geoffroy, (Gray).

$V$. proterus, Kuhl.

$V$. altivolans, White.

V. labiata, (?), Hodgson.

HAB. Europe; Himalaya (?).

A. Specimen from England. H. E. Strickland, Esq. (1845). B. C. Ditto, Mr. Bartlett (1844). D. E. Dried specimens from Nepal (Vesp. labiata, Hodgs.) B. H. Hodgson, Esq. (1844). $F$. Skull of $C$.

Genus Nycticesus, Horsfield.

90. N. ornatus, Blyth, $J$. A. S. XX, 517.

HAB. S. E. Himaláya ; Kás-hya hills.

$A$. Specimen in spirit, from Cherra-Punji. $R$. W. G. Frith, Esq. (1851). B. Skin, purchased from Dorjiling .(1858).

91. N. Heathit, Horsfield, P. Z. S. 1831, p. 113 ; J. $A$. S. XX, 157.

Hав. S. India; Ceylon (darker variety).

$A$. Specimen in spirit. $B$. Skin. Coromandel. W. E. Elliot, Esq. (1843). C. Specimens in spirit. D. Skins. From Ceylon. E. L. Layard, Esq. 1850). E. Skull. Madras. 
92. N. Luters, Blyth, J. A. S. XX, 157; XXI, 346.

Syn. N. Alaveolus, Blyth, M. S., Horsfield's Catalogue. Scotophilus Temminckii, Gray (apud Horsfield), $M . Z$. B. II, 15.

HAB. Bengal; Sylhet; Assám; Burma. Very common about Calcutta.

$A$. Series of stuffed specimens. $D$. Ditto, in spirit. C. Skulls. D. Skeleton. Calcutta.

93. N. Temminckir (Tem. Monog. Mam. II, pl. XLVII).

SYn. Vespertilio Temminckii, Horsfield.

V. Belangeri, Is. Geoffroy, Temminck.

$V$. noctulinus, Is. Geoff. (young).

HAB. India generally (plains); Indo-Chinese and Malay countries.

$A$. Series of stuffed specimens. $B$. Ditto in spirit. C. Skulls, Calcutta. 'D. Very dark specimen from Dacea. Major Tytler (1860).

94. N. castaneus, Gray, apud Horsfield's Catalogue.

Hab. Malay Countries; E. Bengal.

$A$. Stuffed specimen, received from' the Batavian Institution (1845): $B$. Another from Dacca. Major R. C. Tytler -(1860).

95. N. Trckelli, Blyth, J. A. S. XX, 157.

Syn. N. isabellinus, Bl., M.S., Horsfield's Catalogue.

Hab. Central India; Ceylon.

A. B. C. Stuffed specimens from Cháibása. Presented by Major Tickell (1842). D. Skull.

96. N. atratus, Blyth.*

Srn. Scotophilus fuliginosus apud nos, $J . A$. S. XXII, 409.

НАв. Sikhim.

$A$. B. Specimens in spirit. C. Stuffed specimen. Dorjiling. Major W. S. Sherwill (1853).

* Like (Vesp.) Fuliginosa, Hodgson, J. A. S. IV, 700, (which Dr. Gray ranks as a Scotophirds), but with only one pair of upper incisors. Length of forearm $1 \frac{3}{4}$ in. 
97. N. Gouldir, Gray, App. Grey's Narrative, p. 405.

HAв. Australia.

$A$. : Specimen presented by the Sydney Institution (1846).

98. N. (?) Swinhoer, Blyth, J. A. S. XXIX, 88.

Hab. China (Amoy.)

$A$. Specimen presented by R. Swinhoe, Esq. (1859).

99. N. CANus, Blyth.*

Syn. Scotophilus maderaspatanus (?), Gray, Br. Mus. Catal.

Vespertilio, No. 11, Elliot, Madr. Journ. X, 99.

HAB. Plains of India; Bengal. Common.

$A$. Series of stuffed specimens (needing to be renewed); Calcutta. $\uparrow$

Genus Scotornilus, Leach.

100. Sc. Serotinus (Geoff, Ann. Mus. VIII, $t .47,48$ ).

Sxx. Vespertilio serotinus. Schreber.

$V$. noctula apud Geoffroy.

Hab. Europe, Himalaya.

A. Specimen from France, M. Malherbe (1852).

101. Sc. BOREALIS.

Srn. Vespertilio borealis, Nilsson.

V. Nilssoni, Keyser et Blasius.

HAB. Scandinavia. (1846).

A. Specimen in spirit, Christiania University

* A small species, common about Calcutta, with forearm $1 \frac{3}{8}$ to $1 \frac{1}{2}$ in. Colour of fur light dusky, with pale tips, more or less greyish or fulvous, this pale hue prevailing on the under-parts. One specimen obtained (J.A. S. XXII, 348,) is variegated with bright ferruginous. Another and very similar species, also common about Calcutta, has permanently two small pairs of upper incisors, characteristic of ScotopHILUs, instead of the one larger pair, very distantly placed apart, of adult NrcticeJus.

†Desid, N. Nivicolos, Hodgson, Ann. M. N. H., n. s., XVI (1855), p. 104. 
102. Sc. Leisleri (Bell's Br. Quadr., pl. ).

Syn. Vespertilio Leisleri, Kuhl.

V. dasycarpus, Leisler.

Haв. Europe, Himalaya.

$A$. Specimen from England, H. E. Strickland, (1846).

103. Sc. Fulvidus, Blyth, J. A. S. XXVIII, 293.

HAB. Tenasserim provinces.

$A$. Specimens presented by Major Berdmore (1858).

104. Sc. Pumiloides, Tomes, Ann. M. N. H. XX (1857), p. 228.

HAB. China.

$A$. Specimen from Amoy, presented by $\mathrm{R}$. Swinhoe, Esq. (185்).

105. Sc. Coromandelianus (J. A. S. XX , 159-60).

Syn. Vespertilio coromandeliana, F. Cuv̀.

No. XII, Elliot's Catal., Madr. Journ. X, 99.

Kerivoula Sykesi (?), Gray, vide Ann. M. N. $H$. n. s., II (1858), p. 486.

HAB. India generally; Ceylon; Burma; Malayan peninsula to Singapore; Nicobar islands. (About the commonest of Indian Bats).

$A$. Series, requiring renewal. $B$. Ditto in spirit. C. Skulls. Calcutta.*

* Desid.-Scotophilus fuliginosús ; Vespertilio fuliginosus, Hodgson, $J$. $A$. S. IV, 700. Nipal.-Sc. Pachyonyx, Tomes, P. Z. S. 1857 , Ann. M. N. $H$. XX (1857), p. 227. India. Dr. Gray, who unites the Nycticedr with the ScoTOPHIL, gives the following undescribed species in his $B r$. Mus. Catal. 1. "The Indian Bat" ! Sc. Hodgsoni, Gray. Calcutta.-2. Sc. Lobatus. Gray (Vesp. lobatus, Gray, Hardw. Ill. Ind. Zool.) 3. "The Madras Bat" Sc. maderaspatanus, Gray. Madras.-4. Sc. falcatus, Gray. India.-5. Sc. fulvus, Gray. Madras, Jaya. 
Sub-fam. VESPERTILIONINAE.

Genus Vespertilio, L. (apud Tomes).*

106. V. Pearsonit.

Srn. Lasiurus Pearsonii, Horsf. Catal., Blyth, $J$. $A$. S. XX, 524.

HAB. S. E. Himalaya; Moluccas (Amboyna).

$A$. Stuffed specimen. Purchased (1851). $B$, Another in spirit. Presented by W. Theobald, Esq.. Jun. (1854). Both from vicinity of Dorjiling. $\dagger$

Genus Murina, Gray.

107. M. suilla. (Tem. Mon. Mamm. II, pl. 56, f. 7, 8).

Syn. Vespertilio suillus, Tem.

Noctulinia lasiura, Hodgson.

Lasiurus Pearsonii apud nos; J. A. S. XXII, 409.

HAB. S. E. Himalaya; Sumatra; Java.

$A$. Specimen in spirit, from Dorjiling. Major W. S. Sherwill (1853).

Genus Kerivoula, Gray (restricted). $\ddagger$.

108. K. PALLIDA, nobis.§

HAB. Central India.

$A$. to $D$. Specimens from Chaibassa. Presented by Major S. R. Tickell, (1842).

109. K. PICTA (Tem. Mon. Mamm. II, 56, f. 1)。

SYN. Vespertilio pictus, Pallas.

$V$. kerivoula, Boddaert.

HAB. Bengal, Ceylon, Burma, Malay countries.

* Ann. M. N. H., n. s., I (1858), p. 451.

+ Desid.-Vesp. formosa, Hodgson, J.A. S. IV, 700 ; Tomes, in P.Z. S. 1858, or $A n n$. $M . N . H_{.}$., n. s., I (1858), p. 446. Nipal, China.-V. mystacinus (?), Leisler, v. $V$. darjilingensis, Hodgson, apud Tomes, Ann. $M$. $N$. H. XVII, (1856), p. 27. Sikhim.-Vesp. Blythir, Tomes, P.Z. S. 1857, p. 53, or Ann. M. N. H. XX (1857), p. 231. India. (Násirabad).-v. Caliginosus, Tomes, P. Z. S. 1859, 73. India.-v. siligonensis, Hodg., Horsf., Ann. M. N. H. n. s., XVI (1855), 102.

+ Vide Tomes, Ann. M. N. H., n. s. II (1858), p. 473.

$\$$ Much larger than K. PICTA, with the woolly fur shorter, denser, and much paler in coloring,-fulvous, with a slight ruddy or ferruginous cast, paler on the under-parts; the orange portion of the wings broader and less defined. Fore-arm 2-in.; longest finger 3-in.; tail 15 in.; expanse 11 in. 
A. Specimen from Jeypore. J. Payter, Esq. (1852). B. Another, from Ceylon. D. Kelaart (1851). C. Specimen from Java. Presented by the Batavian Institution (1844).*

Genus? Vespertilio apud Gray.

110. V. adversus, Horsfield:

HAB. Bengal; Tenasserim; Ceylon; Pinang; Java.

$A$. Specimen obtained on the Society's premises (1844). B. Skull. C. Another skull, from Ceylon; taken from a much injured skin, presented by Dr. Kelaart (1850).

Genus Mrotis, Gray.

111. M. MURinus (Bell's Br. Quad., pl. ) )

SYN. Vespertilio murinus, Geoff. (nec L,, apud Gray). V. myotis, Bechstein. .

HAB. Europe; Himalaya.

A. Stuffed specimen from Másuri. Presented by Capt. T. Hutton (1852), J. A. S. XXI, 360.

112. M. BerdMorer, nobis, J. A. S. XXVIII, 293.

HAB. Tenasserim provinces.

A. B. C. Specimens in spirit, presented by Major Berdmore (1859).

113. M. PIPISTREllus (Bell's Br. Quadr.; p. )

SYN. Vespertilio pipistrellus, Schreber.

V. murinus, L. (apud Gray).

Haв. Europe; Himalaya?

A. B. Skins. Messrs. Strickland and Davison (1844). C. Skulls. England.

Genus Plecoțus, Geoffroy.

114. Pl. AuRitus (Bell's Br. Quadr., pl. )

* Desid.-Kerivoula papillosa (Vesp. papillosa, Tem.) Bengal ; Ceylon. Vide Tomes in $P . Z$. S. 1858, or Ann. M. N. H., $n_{1}$ s. II (1858), p. 479. 
SYN. Vespertilio auritus, L.

$P l$. communis, Lesson.

Pl. brevimanus, Jenyns.

Pl. homochrous, Hodgson, J. A. S. XVI, 894.

Pl. darjitingensis, (?), Hodgson, Ann. M. N. H., n. s., XVI (1855), p. 103.

Haв. Europe; Himalaya.

A. Specimen in spirit from Dorjiling. Major Sherwill (1853). $\quad B$. C. Examples from England. Mr. Strickland and Mr. Davison $(1844-7)$. $\quad D$. One from France. M. Malherbe (1854).

Genus Barbastellus, Gray.

115. B. communis Gray (Bell's Br. Quad., pl.)

SYN. Vespertilio barbastellus, Schreber.

B. Daubentonii, Bell.

HAB. Europe; Himalaya (vide J. A. S. XXIV, $363)$.

A. Specimen in spirit from Másuri. Presented by Captain T. Hutton (1852).

Genus Nyctophitus, Leach.*

HaB. Australia.

$A$. Specimen presented by the Sydney Institution (1845).

* Vide P.Z.S, 1858, p. 25; or Ann. Mag. N. H., n. s., I (1858), p. 375 .

Note.-Several bottles containing Bats have unfortunately been purloined from the Museum, the specimens doubtless thrown away, and the stoppered bottles disposed of. Among them were a few species perhaps undescribed. Also Megaderma spasma, Geoffroy, from Ceylon (J. A. S. XXI, 746).

Rhinolophus Rouxi, Tem. Bottle containing many specimens, chiefly. procured by Mr. Theobald at Colgong, J. A. S. XXIII, 733).

Hı PPOSIDERos MURINUs (Elliot), from the Nicobar Islands.

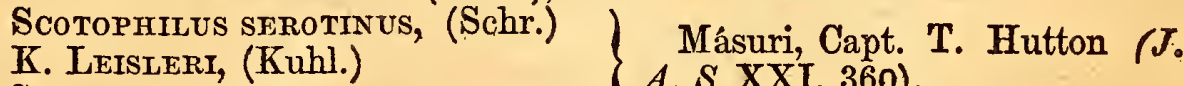

$\mathrm{Sc} \longrightarrow$ A. S. XXI, 360)

Sc. irReTitus (Cantor), from Hong-Kong (J.A. S. XXII, 584).

Kerivoula PICTa, (Pallas). Several examples from Ceylon.

Vespertilio adversus, Horsfield. Three examples from Tenasserim, (J. A. S. XXIII, 831).

Myotis murinus, (Geoff). From Másuri (J.A. S. XXI, 360).

M. TheobaldI, nobis, $J . A$. S. XXIV, $363 ; M$. pallidiventris (Hodgson), apud nos, J.A.S. XXII, 581;M. pipistrellus apud nos, J. A. S. XXI, 360. Másuri.

M. PARVIPES. nobis, J. A. S. XXII, 581. Kashmir.

M? LEPIDUs ; Pipistrellus lepidus, nobis, J. A. S. XIV, 340.

The specimen described was returned to Capt. Hutton. 
116. N. Geoffroyi, Leach.

Syn. Barbastellus pacificus, Gray.

HAB. Europe; Himalaya.

$A$. B. Specimens in spirit. Másuri. Capt. F. Hutton (1844).

Order SECUNDATES. Sub-order CYNODIA.

Fam. CANID $\not$.

Genus Cuon, Hodgson.

117 C. Rutilans (As. Res. XVIII, pt, II, p. 236, pl.).

Srn. Canis rutilans, S. Müller.

C. familiaris, var. sumatrensis, Hardwicke.

C. javanicus, Desmarest.

C. primavus, Hodgson.

C. dukhunensis, Sykes.

Buánsu, Nepal ; Kolsuen, Sanskr., Mahratta ; Jungli Kuta, H. ; Anjing utan, Malay. Rufous or Red Wild Dog of Europeans.

Hab. The more extensive jungles of all India, Burma, Malayan peninsula, Sumatra, Java, and Borneo ; exhibiting slight varieties, and generally believed to form two or three races in most parts of its range.* Tibet (Hodgson)†.

$A$. Specimen from Nipal; dull-coloured, brownish ; C. primavus, Hodgson (in bad condition). Presented by B. H. Hodgson, Esq. (1844). A. 1. Skull. B. Very young. Presented by Ditto. $C$. Deep-coloured specimen, from S. India; C. dukhunensis, Sykes (in bad order) Presented by Dr. Jerdon (1846). N. B.-Tail a full brush (not as represented by M. Adolphe Delessert). D. Female adult. E. Male, one-third grown, from Chaibása,

* Vide J. A. S. XI, 591, XV, 196, Ann. Mag. N. H. XV (1845), p. 196 ; Horsfield's Catal. Mamm., p. 80 ; and P.Z. S., 1858, p. 514. 278 .

$\dagger$ "The breed of Tibet is large and of a pale Wolf-like colour." J. A.S.XI, 
C. India (and quite similar to examples received from Asám). Presented by A. Grote, Esq. (1856). $D$. 1. Skeleton of $D . F$. Specimen with long soft fur and dense under-coat, a very full brush, and moderately bright-coloured; described $J . A . S$. XXV, 440. Presented by Messrs. Colvin, Ainslie, and Co. (1856). $F$. 1. Skeleton of $F$.

Remark.-The various races of this animal do not appear to differ osteologically; nor, for that matter, do various typical Foxes that are regarded by most naturalists as species.

\section{Genus Canis, L. (restricted).}

\section{C. FAMILIARIS, L.}

Kuta, $\mathrm{H}$.

HAB. Wherever man inhabits, in multitudinous breeds and races : an artificial species, consisting of the more or less altered descendants of sundry wild species or races (of Wolves and Jackals), variously intermingled.

A. Newfoundland Dog. Skeleton of female. Presented by R. W. G. Frith, Esq. (1852). $B$. Skull. Society's old collection. C. Skeleton of Greyhound, Presented by R. W. G. Frith (1853). $D$. Skull and part of skeleton of Dingo, (C. dingo, Blumenbach, C. familiaris Australasiae, Desm), Australia. Presented by C. Hollings, Esq. (1856). $\boldsymbol{E}$. $\boldsymbol{F}$. Skulls of Pariá Dogs. Presented by G. S. Lushington, Esq. (1835). G. H. Skulls. W. Masters, Esq. (1845). I. Dog-skull from Formosa. J. Ditto from Amoy. Presented by $\mathbf{R}$. Swinhoe, Esq. (1859). Vide J. A. S. XXIX,88.

(Section Lupus, C. Ham, Smith. Wolves.)

119. C. Alpinus (?) Pallas, Fauna Rojss.-As., p. 34 (ed. 1831).

Hab. E. Siberia, Altai Mountains ; Tibet. $A$. Large red Wolf, or very Wolf-like Dog, from Tibet. Presented by Capt. Munro (1845). 
(Accords tolerably with the description of $\mathrm{C}$. ALPINUS, except that the tail is uniformly rufous.)

120. C. Lupus, L. (F. Cuvier, Mamm. Lith.)*

Sr̀n: C. lycaon, L. (Melanoid var.)

Hab. Europe; Siberia.

$A$. Stuffed specimen from Norway. $B$. Skeleton from Norway. Presented by the University of Xia (1844).

121. C. Pallipes, Sykes.

Syn. C. lupus of India, auctorum.

Bharyá, H. Nek̀rá, H. Laudgah, Dukháni. Tola, Canarese.

$\mathrm{H}_{\mathrm{AB}}$. Plains of India.

$\dot{A}$. Speçimen from Chaibása, C. India. Presented by Major S. R. Tickell (1848). B. Another, from Pind Dádun Khán. Presented by W. Theobald, Esq. (1854). C. Skull, taken from stuffed head (1856).

122. C. LANIGER.

Srn. Lupus laniger, Hodgson.

Changu of Tibetans (Hodgson).

Haв. Tibet.

A. B. C. Stuffed specimens. Presented by G. S. Lushington, Esq. (1844-6). D. Skin of a melanoid individual. Presented by Lieut. Strachey (1847). J. A. S. XVI, 1176. E. F. G. H. Skulls. Presented by G. T. Lushington, Esq. (1835).

(Section Saccalius, C. Ham. Smith. Jackals.)

123. C. melanotus (?), Pallas.

Syn. Jackal of Eastern Turkestân, Timkowski, Lloyd's Transl. I, 406.

HAB. Chinese Tartary.

* Mons. F. Cuvier's figure of a French Wolf represents an animal seemingl intermediate to the Scandinavian and Indian races. 
Genus Cynalopex, C. Ham. Smith.

126. C. Bengalensis (Hardw., Ill. Ind. Zool.; As. Res. XVIII, pt. II, 226, pl. $\quad$ ).

Syn. Canis bengalensis, Shaw.

C. rufescens et C. chrysurus, Gray.

C. kokri, Sykes.

Vulpes bengalensis, Sykes.

$V$. indicus, Hodgson.

C. corsac of India, auctorum.

Lumri, H. ; Kháksheáli, B. ; Kokri, Mahr. ; Konk, Kempnari, and Chand saknari, Can.; Lomer of Nipalese (Hodgson).

$\mathrm{H}_{A B}$. India generally (very rare within the confines of Asám). Ceylon? (Badulla district).

$A$. B. C. D. Adults and young, from vicinity of Calcutta. E. Skeleton. F. G. H. Skulls.

127. C. (?) ferrilatus, $J$. $A$. S. XI, pl. , p. 289).**

Syn. Vulpes ferrilatus, Hodgson.

Has. Tibet.

$A$. Adult. B. Young, more than half-grown. Presented by Dr. A. Campbell (1853), J.A.S. XXII, 415.

Genus Megalotis (Illiger ?), C. Ham. Smith. $†$

128. M. CAAMA.

Syn. Canis caama et C. chama, A. Smith.

Hab. S. Africa.

$A$. Specimen presented by E. L. Layard, Esq. (1859).

* Dr, J. E. Gray, in his Catalogue of Mr. Hodgson's collection (1846), enumerates C. corsuc, L., and Vulpes ferrilatus, Hodgson, as synonymes of C. BENGALENSIS. C. (?) FERRILATUS is most conspicuously distinct, with ears smaller by one-half, a shortcr and largely white-tipped tail, \&c.-Vide J.A.S. XXIII, 731. In his Brit. Mus. Catal. (1842), p. 61, Dr. Gray admits "Vutlpes corsac" from Siberia. C. (?) FERRILATus docs not at all accord with the descriptions of $C$. consac ; but the form approachos much nearer to that of C. consac (as figured by Pallas, ) than to that of C. Bengalensis. Indecd, the propricty of ranging $\mathrm{C}$, Colis $A$ C and C. FERrilatus in the same minimum division is doubtful. C. FERrilate is now in the India-house muscum. Vide P. Z. S. 1856, p. 397.

+ Megalotis, C. H. Smith, is reforred to Oetocyon, Licht., in Dr. Gray's CataIogue ; but pidc Nat. Litr., Canide, II, 290, 298, where Agriodus =Otocyon . 
Genus Vulpes, Ray.

129. V. (?) Lagorus (Nilsson, Faun. Sc., t. 6, 7).

Srn. Canis lagopus, L.

C. fuliginosus, Shaw.

Hab. Arctic regions.

$A$. Stuffed specimen. Presented by the University of Xia (1844). B. Skull. Presented by the Royal Academy of Copenhagen (1839), J. A. S. VIII, 968,

130. V. vulgaris, Brisson (F. Cuv., Mamm. Lith., II, t. $\left.48^{*}\right)$.

Syn. Canis vulpes, L.

Hab. N. and Middle Europe and Asia. $\dagger$

A. B. Stuffed specimens. Mr. Bartlett (1843).

C. Skeleton. Presented by J. H. Gurney, Esq.,

M. P. (1860), D. E. F. Skulls. Mr, Bartlett.

131. V. montanus, Pearson.

Sxn. V. himalaicus, Ogilby.

Hab. N. W. Himalaya.

$A$. Specimen described by Dr. Pearson, $J . A . S$, V, 313. B. Another. Presented by Capt. T. Hutton (1844). C. Another. Presented by Dr. L. C. Stewart (1854).

132. V. flavescens, Gray, An. M. N. H., XI, 118.

Syn. V. nipalensis, Gray, An. M. N. H., n. s., I, 578.

$V$. montanus apud Hodgson (nec Pearson); also apud Horsfield, P. Z. S., 1856, p. 397. Wamer of Nipalese (Hodgson).

Hab. Tibet.

$A$. B. Specimens presented by G. T. Lushington, Esq. (1847), J. A. S. XVI, 385.

* The figure referred to suits quite as well No. 131 as No. 130 ; but the races are barely separable.

$\dagger$ "Vulpes per universam et Europeam partem Imperii [Rossici], et in omni Siberia frequens animal, in campestribus australibus colore et vellere degener, pulchrior in frigidis borcalibus et orientalibus, pulcherrima præsertim, maximeque rutilo colore in Camtschatkâ, quæ ignitæ (Ognaenki) pellionibus dicuntur." \&c., \&c. Pallas (Fauna Rosso-Asiatica, p. 47, edit. 1831). 
133. V. pusillus, Blyth, J. A. S. XXIII, 729.

Syn. V. Alavescens apud Bl., J. A. S. XXII, 581.

Hab. Punjáb salt range.*

A. B. Specimens presented by W. Theobald, Esq. (1853). A, 1. Skull.

134. V. Griffithir, Blyth, J. A. S. XXIII, 730.

Syn. V. flavescens apud Bl., J. A. S. XIV, 344.

Hab. Afghánistân.

A. Specimen presented by Capt. T. Hutton (1845). $A, 1$. Skull.

135. V. Leucopus, Blyth, $J$. A. S. XXIII, 729, XXV, 443, XXVI, 239.

Hab. Desert regions of N. W. India.

A. Specimen originally described. Presented by ? B. Another. Presented by

Dr. D. Scott (1857). C. Skuill: Sent.with $A$.

136. V. virginianus, Gmelin (F. Cuv., Mamm. Lith., II, t. 49).

Syn. Canis griseus et cinereo-argentatus (?), Schreber.

Vulpes cinereo-argentatus, Richardson.

' Kit-fox' of Anglo-Americans.

HAB. N. America, in open plains.

$A$. Specimen presented by Dr. Rüppell (1855).

Fam. VIVERRID $\mathbb{A E}$.

Sub-fam. $H Y X E N I N \not E$.

Genus Hy zina, Brisson.

137. H. Crocuta, var., J. A. S. XXIV, 292.

Syn. H. crocuta rufa (?), Fischer.

Hab. Somâli country, E. Africa.

$A$. Stuffed skin (bad). $A, 1$. Skull from $A$. Presented by Capt. Burton and Capt. Speke (1855).

* Very distinct from No. 135 ; though supposed to be identical with it in Proc. Zool. Soc. 1858, p. 516. 
138. H. striata, Zimmerman (F. Cuv. Mamm. Lith. I, t. 55).

Syn. Canis hyana, L.

H. vulgaris, Desmarest.

H. orientalis, Tiedmann:

H. antiquorum, Temminck.

Hundar, H.; Láker Bagh, H.; Turrus,

Mahr.; Kirba and Kutt kirba, Can.

HAB. India generally (nec Lower Bengal); ${ }^{*}$ W. Asia; N. Africa. Common on the southern promontory of the Caucasus (Pallas).

$A$. Stuffed specimen. $A$ 1. Skeleton. Presented by the Curator (1853). B. C. D. Skulls.

Genus Proteles, Is. Geoffroy.

139. Pr. Cristatus (Mem. Mus. XI, t. 20).

SYN. Viverra cristata, Sparrman.

$V$. hycenoides, Desmarest.

Pr. Lalandi, Is. Geoffroy. Aard-wolf, Cape colonists.

Hab. S. Africa.

A. Specimen presented by E. L. Layard, Esq. (1859).

Sub-fam. VIVERRINAE。

Genus Viverra, L.

140. V. Civettina, Blyth. $\dagger$

Syn. V. zibetha apud Waterhouse, Cat. Zool. Soc. Mus. (1838), No. 252.

Haв. Malabar; Travancore; Ceylon?

$A$. Specimen (in bad order). Presented by Lord A. Hay (1845).

* Stragglers very rarely extend their nocturnal wanderings even to the vicinity of Calcutta ; and I have recently learned of an instance of a Wolf (CANIS PALLIPES) being killed close to Calcutta,-but I have heard of no other instance.-E. B.

+ Like the African V. civetra, but the mane commences between the shoulders, instead of from between the ears. Vide J.A.S. XX, 160. The difference, however, is scarcely. greater from V. zIBETHA, than in the most dissimilar examples of Felis bengalensis. 
141. V. zibetha, L. (Calc. Journ. N. H. I, pl. 1).

Syn. Meles zibethica, L.

V. undulata, Gray.

V. melanura, orientalis, et civettoides, Hodgson.

$V$. bengalensis, McClelland.

Kutas, Mátch Bhondor, B.; Kyoung myen, Arakan (Phayre); Tanggalung, Malay.

Hab. Bengal, Nipal, Indo-China, S. China, Malayar peninsula.

$A$. Stuffed specimen. Presented by Dr. Wallich (1842). B. Another (1856). C. Small young. $D$. Skeleton. E. F. Skulls.

142. V. tangGalunga, Gray (F. Cuv., Mamm. Lith., II, t. 51).

Syn. V. zibetha apud Raffles et F. Cuvier.

Tanggalung, Sum.; Musang Jebat, Malay.

Hab. Malayan peninsula, Sumatra, Borneo, Celebes, Amboyna, Philippines.

A. B. Specimens from Malacca. Presented by the Rev. F. W. Lindstedt (1846).

Genus Viverricula, Hodgson.

143. V. malaccensis.

SYn.'Viverra malaccensis, Gmelin.

$V$. indica, Geoffroy.

$V$. rasse of India, Sykes, Gray.

$V$. pallida, Gray and Hardwicke, var.

Gandha Gokûl, B.; Sayer and Bugmyul, in Tarai (Hodgson); Juwardi Marjar, Mahr.; Wa-young-kyoung-bouk, Arakan (Phayre).

HAB. India generally ; Ceylon ; Indo-China ; Malayan peninsula.

$A$. to $J$. Series of specimens of various ages, and illustrative of individual variation. $K$. Skele ton. $L$. Skull of young individual. 
Genus Genetta, Cuvier.

144. G. AFrA, Desmarest (F. Cuv., Mamm. Lith., I, t. 64, III, $t .47)$.

SYN. Viverra genetta, L.

Hab. N. Africa.

A. Specimen from Algeria. Presented by M. Malherbe (1848).

145. G. TIGRINA.*

SYN. Viverra tigrina, Schreber.

G. vulgaris, Rüppell.

$A$. B. Specimens from S. Africa. Presented by

E. L. Layard, E\&q. (1859).

Genus Prionodon, Horsfield.

146. Pr. Pardicolor, Hodgson, J. A. S. II, 57.

Hab. S. E. Himalaya.

A. Specimen presented by Mrs. Saxon (1844).

Genus Hemigalea, Jourdain.

147. H. Derbiana (S. Müller, Mamm. pl. 18).

Syn. Paradoxurus derbianus, Gray.

H. zebra, Jourdain.

Viverra Boieri, S. Müller.

Musang Bátu or Sángah Prao, Mal. (Cantor).

HaB. Malayan peninsula, Borneo.

A. Adult, from Malacca, M. de Storr (1843). $B$. Young, two-thirds grown. Malacca. Presented by E. Lindstedt, Esq. (1847).

Genus Paradoxurus, Cuvier.

148. P. musanga (F. Cuv., Mamm. Lith., II, t. 55).†

SYN. Viverra musanga, Marsden.

$V$. hermaphrodita, Pallas.

V. nigra, Desmarest.

* The difference of markings of the Genets is much that of different varieties of Felis bengalensis.

$\uparrow$ Tail malformed, or the result of disease; as seen occasionally. Hence the inappropriate name Paradoxurus ! 
P. typus, F. Cuvier.

P. Pallasii, Gray.

P. Crossii, Gray.

$P$. dubius, Gray.

$P$. felinus, Wagler.

apud Schinz.

P. musangoides, Gray.

Platyschista Pallasii, Otto, apud Gray.

Bhondor, B.; Lakáti, H.; Musang Bulau, Malay; Kyoung-woon bouk, Arakan (Phayre.)

'Palm-cat' of Europeans in Ceylon.

HАв. India generally, Ceylon; Indo-China; Malayan peninsula; Sumatra; Java; Borneo; Timor; Andamán islands?

$A$. B. Adults. C. D. Young. $E$. Very spotted individual (undistinguishable from Malayan var.) FF. Pied specimen. All from vicinity of Calcutta. G. $H$. Adults. J. $K$. Young, Malacca. Presented by Messrs. Frith and E. Lindstedt (1843-7). $L$. Skeleton. $M$. $N$. Skulls. $O$. Skull of a very aged animal, from Port Blair, Andamán islands. Referred with doubt to this species-vide $J . A$. S. XXIX, 102.

149. P. zeylanicus, J. A. S. XX, 161, 184.

SYn. Viverra ceylonica, Pallas.

V. zeylanica, Schreber.

$V$. ceylonensis, Boddaërt.

$P$. montanus, Kelaart, var.

Hab. Ceylon.

A. B. Adults. C. Young. Presented by E. L. Layard, Esq., and Dr. Kelaart (1849).

150. P. trivirgatus, Tem. Monagr., II, $t .62, f .1)$. SYN. Viverra trivirgata, Reinwardt. Musang ákar, Malay.

Hax. Malayan peninsula; Sumátra; Java; Tenasserim.

A. Adult. B. Young, from Malacca. Presented by the Rev. F. J. Lindstedt, and Mr. Moxon $(1846-7)$. 
151. P. Leucotis, Blyth, J. A. S. XXVII, 274.

Na-zwet-phyoo, Arakan (Phayre).

HAB. Sylhet; Arakan; Mergui; Burmese countries. A. B. Specimens presented by F. Skipwith, Esq., C. S. (1845), and by Col. Phayre (1846). C. Skull.

152. P. LANiger (?), Hodgson, vide J. A. S. XXVII, 274. Haв. Himalaya.

$A$. Specimen presented by the Máharaja of Burdwán, described loc. cit. (1858).

153. P. Leucomystax, Gray (Tem. Monagr., II, $t$. 64, $f .4-6)$.

Srn. Amblyodon auratus. Jourdain, apud Gray. Musang bulan, Malay.

HАв. Malayan peninsula; Sumátra.

A. B. Specimens from Malacca. Presented by the Rev. F. J. Lindstedt and Mr. Frith (1845-6).

154. P. Grayi, Bennett (Tem. Monagr. II, 332, t. 65, $f .4-6)$.

Syn. $P$. bondar, Tem. (nec Gray).

$P$. Jourdainii, Gray.

P. nipalensis, Hodgson.

Haв. S. E. Himalaya, Arakan mountains.

$A$. Specimen (white-tailed), from Arakan. Presented by Col. Phayre (1844). B. C. Others from Dorjiling. Presented by Dr. Stewart (1856).

155. P. Rubidus, Blyth, J. A. S. XXVII, 275.

$\mathrm{H}_{A \mathrm{~B}}$.

$A$. Specimen purchased (1857).*

* Desid.-P. strrictus, Hodgson, Ann. Mr. N. H., n. s. (1855), p. 105. Nipal tarai. - P. Quadriscinters, Hodgson, ibid., p. 106. Nipal hills. P. mondar (Viverra bondar, Blai nv., v. P. Pennantii, Gray). Nipâl. - P. Nigiturons, Gray. "India." \&c. \&c. 
Genus Cynogale, Gray.

156. C. Bennetrit, Gray (S. Muller, Zool. Ind. Arch., Mamm. t. 17).

Syn. Viverra (Limictis) carcharias, Blainville. Potamophilus barbatus, Kuhl.

Hab. Malayan peninsula; Sumatra; Borneo.

A. Specimen presented by the Rev. F. J. Lindstedt (1845). A, 1. Skull.

Genus Arctrictis, Temminck.

157. A. Binturong (F. Cuv., Mamm. Lith. III, 50, 51 ; Tem. Monagr. t. 62).

Syn. Viverra (?) binturong, Raffles.

Paradoxurus albifions et Ictides ater, F. Cuvier. Arct. penicillata, Temminck.

Myouk-kya ('Monkey Tiger'), or Kyoung myee Jouk, Burm. (Phayre); Young, Upper Asám; Menturong, Malay (Cantor).

Hab. Upper Asám hills, S. of Brahmaputra; Arakan; Tenasserim provinces; Malayan peninsula. Butan? Nipal?

A. Very large male, from Arakan. Presented alive (when very young) by Col. Phayre, $J . A$. S. XVI, 864 ; XXIII, 210-vide. B. Female. Presented by Dr. Falconer (1854). A 1. Skeleton of $A .-B$ 1. Skeleton of $B$. C. Skull.

Sub-fam. HERPESTIDINAE.

Genus URva, Hodgson, (C. J. N. H. II, 458, $t_{0}$ ).

158. U. CaNCrivora, Hodgson, J. A. S. VI, 561.

Sxn. Gulo urva, Hodgson, J. A. S. V, 238.

Urva, Nipâl,(Hodgson); Mwai-ba, Arakan (Phayre).

HAB. Nipâl ; Khásya Hills ; Arakan* (nec Afghánistân); Tibet (Hodgson).

$A$. Adult. B. Young. From Arakan. Presented by Col. Phayre (1843), $A$ 1. Skull of $A$.

* No other kind of Mingoose observed in Arakan (Phayre). 
Genus Mungos, Ogillby.

159. M. vitTicollis (Madr. Journ. Lit. Sc. X, t. 2).

SYn. Herpestes vitticollis, Bennett.

НАB. Malabar ; Ceylon.

$A$. Specimen from Malabar. Presented by Dr. Jerdon (1846). B. Another, from Ceylon. Presented by E. L. Layard, Esq. (1848). $A 1$. Skull of $A$. D. Skull of immature animal. Presented by the Curator (1844).

160. M. Fasciatus, Buffon (XIII, t. 19 ; Rupp, Faun. Abyss. t. 9, f.: 2).

Srn. Viverra mungo, Kœmfper.

V. ichnuemon apud Schreber.

Herpestes fasciatus, Desmarest.

H. zebra, Rüppell.

Ryzoena suricata apud Children (App. Clapperton's Travels).

Hab. Medial and S. Africa.

A. Specimen from the Somâli country, E. Africa. Presented by Captain Burton and Captain Speke (1855), J. A. S. XXIV, 293.

Genus Herpestes, Illiger.

161. H. IChndemon (Buff. Supp. III, t. 36 ; Edwards's Birds, pl. 199 ; F. Cuv., Mamm. Lith., II, t.53).

SYN. Viverra ichnuemon, $\mathrm{L}$.

Ichnuemon Pharaonis, I. Edwardsii, et H. major,

Geoffroy.

I. agypti, Tiedemann.

I. Plinii, Shaw.

Haв. Africa.

A. Specimen from S. Africa. Presented by E. L. Layard, Esq. (1859).

162. H. Sмiтнir, Gray, M. N. H. 1827, p. 2 .

Syn. H. rubiginosus, Kelaart, J. A. S. XX, 162.

H. Ellioti, Blyth, J. A. S. XX, 162. 
Hab. Nilgiris ; Ceylon (nec S. Africa).

A. Specimen. Presented by Dr. Kelaart (1852). $A$ 1. Skeleton of $A$.

163. H. MalaCCensis F. Cuv., Mramm. Lith., I, t. 65).

Syn. Mangusta malaccensis, Fischer.

H. nyula, Hodgson, J. A. S. V, 236 and of

Malayan peninsula, auctorum.

H. griseus of Bengail.

$$
\text { Nyul, H.; Benji, B. }
$$

HАB. Bengal; Nipal; Malayan peninsula; Ceylon. $A$. B. Adults. C. Young. Bengal $(J . A . S$. XX, 161-2). 1843-5. D. Specimen with very rufous head and tail tip. $E$. Albino, presented alive by Geoffroy Finch, Esq. (1848).

164. H. GRISEUS.

Syn. Ichnuemon griseus, Geoffroy.

H. pallidus, Schinz.

Mangusta mungos (et caffra), Elliott.

Mangutia v. Viverra mungo, Kompfer (apud Gray).

Mungi mungusa, Telegu.

Hab. Upper Hindustân ; Dukhun ; S. India generally.

A. Specimen from Agra. Presented by L. C. Stewart, Esq. (1848).

165. II. nipalensis, Gray, M. N. H., n. s., I, 578.

Syn. H. auropunctatus, Hodgson.

H. griseus apud Hutton,.J. A. S. XIV, 346.

H. pallipes, Blyth.

Maosh-khoorma, Pushtu, (Hutton).

Hab. Upper India generally, with Bengal; Punjab; Afghánistân; Chittagong; Malayan peninsula (Cantor).

$A$. B. Adults. C. Dt Young. From the Society's compound (1843). E. F. Specimens, one very rufous, from Midnapore. Presented by Captain R. Rollo (1844). G. H. Specimens, one 
very pale, from Agra. Presented by Dr. Stewart. I. Example from Chittagong ( $\boldsymbol{H}$. javanicus apud nos J. A. S. XXI, 349). Presented by Dr. Thorbuin (1846). J. K. Skulls.

166. H. Fulvescens, Kelaart, J. A. S. XX, 162, 184 ; XXI, 348.

Syn. H. flavidens, Kelaart (inapplicable).

Hab. Ceylon.

A. Specimen. Presented by Dr. Kelaart (1852). $A$ 1. Skull.

167. H. Fuscus, Waterhouse, $P . Z$. S. 1838, p. 55.

НАв. Nilgiris; Malabar ; Travancore.

A. Specimen. Presented by Dr. Jerdon (1842).

168. H. CAFFER, Wagner.

Syn. Viverra cafra, Gmelin.

Hab. S. Africa.

A. Specimen presented by E. L. Layard, Esq. (1859).

169. H. Paludosus, Cuvier.

Syn. H. palustris, Rüppell.

H. griseus apud Burchell.

Mangusta urinatrix, A. Smith.

HAB. S. Africa.

A. Specimen presented by E. L. Layard, Esq. (1859).

170. H. BRachyurus, Gray, $M . N . M . \mathrm{I}, 578$.

$$
\text { Musang Tierou, Malay (Cantor). }
$$

Hab. Malayan peninsula.

A. Specimen presented by C. Huffnagle, Esq. (1846).*

* Desid, H. Jayanicus, Desm. (F. Cuy. MIamm. Lithog. II, t. 54). Malay countries. 
Fam. FELID $\nexists$ E。

\section{Genus Felis, L.}

(The first great division of Cats has constantly a more robustly formed skeleton; ear-conch short and obtuse; black, with a pale central spot externally).

171. F. LEO, L. (Bennett's 'Tower Menagerie,' fig. XXIV,
from a Hurriana specimen).

Srn. Leo barbarus, capensis, senegalensis, gambianus, persicus, \&c., auctorum: (F. Cuvier, Mamm. Lith. I, t. $45,46,47,48)$.

$F$. leo goojrattensis, Smee.

Singha, H.: Shingál, B.; Ontiá Bágh

('Camel Tiger'), Káttyawar.

Has. Africa: Arabia, Mesopotamia, Persia ; formerly Syria, Greece, Macedonia ; $\dagger$ and (within the present century) the N. W. parts of Hindustan, from Buháwalpur and Sindh to at least the Jumna (about Delhi), southward as far as Khándeish, and in Central India the Sâgur and Nerbudda territories, Bundelkund, and so far west as Pálamow; but at present confined in India to the province of Káttyawar, in Guzerát.

There is reason to believe that the Lion formerly inhabited the plains of Upper India generally, if not also the table-land of the peninsula. In the early part of the sixteenth century, Báber mentions that the wild Elephant, the Rhinoceros, the wild Buffalo, and the Lion inhabited the Benáres district.

Remarks. -The Guzerát Lion is fully maned, and not a nearly maneless variety, as stated by Captain Smee; whose figure represents an immature animal. Maneless individuals, however, whether or not constituting a particular race, occur also in Mesopotamia, and even in

* Erroneously described as a Bengal specimen.

+ The grcat Fels of the British cave deposits is now bclicved to be no other than F. LEo. Vide Asie Mineure, pt. II, by P. de Tchihatcheff, for details of the history of the Lion in that region. 
Africa (vide Barth's Travels, I, 482 ; V, 971, 270). Wherever found, the species appears to be subject to much individual variation of eoloring of mane and of general aspect.*

The Lion was extirpated in Hurriána, about 1824. A female was killed at Rhyli, in the Dumaoh distriet, Sîgur and Nerbudda territories, so late as in the eold scason of 1847-48; and about the same time a few still remained in the valley of the Sinde River in Kotah, Central India. The species would appear to be now exterminated in that district.

$A$. Skeleton of an adult male, from Algeria; received from Mr. Bartlett (1849). The skin of the same individual was formerly mounted in the museum; but having been originally prepared with brine, which could not be sufficiently extracted, the salt deliquesced so much during successive rainy seasons, that the skin became completely destroyed in six or seven years. $\dagger$

\section{F. TIGRIS, L. (F. Cuv. Mamm. Lith. I, t. 49 ; Bennett, Tower Menag. f.)}

Syn. Tigris regalis, Gray.

Shér, H. ; Bágh, B. ; Puttite Wagh ('Striped Tiger'), Mahr.; Rimau or Hariman, Malay; MLachan, Jav. (Horsfield).

HAB. India generally, extending to the most elevated forests of the Himalaya; but not Ceylon. Peculiar to Asia and its archipelago, under very different climatal conditions; unknown in high Central Asia, but inhabiting so high

* Since the above was written, I have seen Mr. P. I. Sclater's 'Guide to the London Zoological Gardens', August 1859. The Secretary of the Zoological Society remarks that-"The Lion is subject to great individual variation, in size, color, and expression; so that it is difficult to determine whether the Lion of Asia really differs more from the Lion of South Africa than the Lion of South Africa from that of Ashantee, Barbary, or Nubia, or than individuals of any of these races differ from each other. It was alleged some time ago that the Asiatic Lion was maneless. But the Guzerat Lion presented by the Raja of Junághur, through Sir Erskine Perry and Colonel Jacob, which lived in the menagérie from 1854 to 1857 , was as thoroughly maned as the Nubian Lion, of which the Society has a fine seven-year-old specimen. The Babylonian Lion, presented by Mr. Alderman Finnis in 1856, is now more fully maned in proportion to his age than the Cape Lion next to him. In colour Lions vary from deep red chesnut-brown to grey, so silvery as to have given rise to the belief that a race of white Lions exists in South $\Lambda$ frica. The colour of the mane varies equally."

$\uparrow$ The skull of a Lioness presented by the Marquis of Hastings, as noticed in As. Res. XIII, App: XVI, is not now in the museum. 
as the 50th parallel (Pallas); and occurring' westward so far as Ararát, and in Turkish Georgia, both W. and S. of the Caspian Sea (ancient Hyrcania); also round the Aral at all seasons; and thence to the Altai, and banks of the Oby, in S. Siberia; numerous in Mantchuria, and very destructive in the valley of the Amûr; again in China, at least to the southward (as near Amoy); $*$ and abundant throughout the Indo-Chinese countries, Malayan peninsula, Sumátra, Java, and Báli (but not Borneo). Tartary and China (Duhalde). Bokhára (Burnes). For the most part, much commoner in its tropical haunts. $\dagger$

A. B. Adult male and female, from the Barrackpore menagérie (1844-6). C. Cub. Presented by the Curator. $A .1$. Skeleton of $A$. $D$. Skeleton of cub. $E . F$. Skulls of males. $G$. $H$. Ditto of females. I. Humerus, radius, and ulna, of an enormous Tiger, the humerus exhibiting a repaired fracture.

\title{
173 F. Pardus, L. (F. Cuv. Mamm Lith. T, t. 51 ; Bennett's Tower Menagerie, t. ).
}

\author{
SYN. F. leopardus, L. \\ F. varia, Schreber. \\ F. nimr, Ehrenberg. \\ $F$. panthera, Pallas.
}

* Vide J.A.S.

+ "Apparet interdum circa Dalai-noor et Argunum, sed datur in omni deserto inter Siberiam et Chinam atque Indiam, ut et in montibus Altaieis extra imperii fines sitis, eircaque Araliensem laeum. Tybetani odore allii eontriti, eirca domieilia in saeculis suspensi ; eontra 'Tygrides sese defendere dicuntur." Pallas, Zoographia Rosso-Asiatica, p. 16. (Edit. 1831.) I have met with no reeent aeeounts of this animal in Tibet proper. Baron Humboldt notiees that "Le Tigre royal, la même espêee qui habite les régions tropieales le l'Inde et de l' Isle de Ceylan, pareourt dans l'Altai. Il ne se montre pas soulement de nos jours dans les plains de la Dzoungarie, mais il avanee vers le nord, entre le Sehlangenbarg et la ville de Barnaoul jusqu'aux latitudes de Berlin et de Hamburg." (Asie Centrale I, 340, edit. 1843.) Nor would the size appear to be inferior to those of Bengal. (Vide Asie Centrale, III, 90.) I have reason to believe that the stature of the largest Tigers eonsiderably excceds that of the largest Lions; and this opinion is confirmed by an experienced Lion-hunter in S. Afriea, who assures me that he never saw a Lion-skull approaching in magnitude to the largest Tiger-skulls in the Society's museum. 
F. antiquorum, Fischer.

F. chalybeata, Hermann.

F. longicaudata, F. Cuv.

F. melas, Peron. $\}$ Melano or melanoid variety.

F. precilura (?), Valencicnnes.

Leopardus varius, Gray.

Tendwa, H.; Chita-bágh, H.; Chita, Mahr. (applied both to this species and to No. - ); also Singhal, Mahr.; Gorbácha, Dukh.; Syik, or Syiák, Lepcha ; Theet-kya, Burm.; Hariman Bintang, Mal.; Machan or Meong tootool and Machan batakh, Jav. 'Tiger' of Ceylon and of different African colonies.

HAB. All Africa; S. Asia (to borders of snow range in Himalaya); Afghánistân ; Persia ; Malayan peninsula; Sumátra ; Jáva ; Armenia, around Ararat (Guldenstadt and Pallas); rare in Caucasus; and occurs in the mountains S. of Lake Aral.

Remarks.-Much difference of opinion still prevails among zoologists respecting the unity or plurality of species of Pard in Asia and Africa. In Baron Cuvier's opinion, only one species inhabits Africa, for which he adopts the name $F$. pardus; and $F$. leopardus he considered to be an inhabitant of those parts of South Asia which were least known to the ancients, viz. the regions adjacent to the Straits of Sunda. F. Cuvier remarks that the Panther brought from India (i. $e$ : from Malabar and Ceylon) has a longer tail than the $F$. pardus of Barbary; whence the former was termed by him $F$. longïcaudata. According to Temminck, $F$. pardus is the smaller of the two, "with tail as long as the body and head, its extremity when reflected reaching to the tip of the nose"; whereas in F. leopardus "the tail is as long as the body only, its extremity, when reflected, reaching only to the shoulders. Caudal vertebre of $F$. pardus, 28; of $F$. leopardus, 22". This authority considers that the true $F$. pardus was unknown to Cuvier; and that the 'Panther' of Cuvier, and 'male Panther' of Buffon and Schreber, are to be viewed as 'Leopards.' $\mathrm{He}$ is further of opinion that the 'Leopard' is confined to the east; and the 'Panther' may be Asiatic as well as African, for aught stated to the contrary. To complicate the matter further, Dr. S. Müller (the subsequent colleague of Professor Temminck) asserts that $F$. leopardus has not been found in the Indian archipelago, and $F$. pardus only in Sumatra and Java. Dr. J. E. Gray considers both as one. According to $\mathrm{my} \mathrm{cx-}$ perience, the tail of an Indian or Malayan Pard, when reflected, would reach forward beyond the shoulders ; and the number of caudal vertebra is 24 or 25. M. Valenciennes has recently distinguished a race from the Gabūn territory, West Africa, with very long tail spotted below as above, by the name $F$. pocilura (Comptes Rendus, tom. XLII, 1036); perhaps the $F$. pardus apud Temminck. 
F. pardus and F. leopardus are placed in Mr. Hodgson's catalogue as distinct species. The Hon'ble W. Elliot, in his catalogue of mammalia inhabiting the S. Mahratta country, remarks of "F.pardus, L.",-- "Of this species there appear to be two varieties, a large and a small kind. The natives distinctly recognise the two kinds by different names. The larger variety is the Honigar in Canarese, Tendwá, Dakhàni, Tendowa of the Bauris or Chita-catchers, and Asnea, Mahrátta of the Ghâts: the smaller oxe-Kerkal, Canarese-Gorbácha, Dakhăn-and Bibla of the Bauris." * Another excellent observer distinguishes three races in the N. W. Himalaya, more or less confounded by the natives under the name 'Bay-heera'. The largest, or Tahir-hay (from its preying on the Tehr or Táhir) "has a much larger head" than the rest. The second is more common, and is named "Ghur-hay or Dheer-hay, from its paying such frequent visits to the villages" The third or Goral-kay " is not more than two-thirds the size of the last, much paler in colour, and the spots are smaller and more numerous." + The Tahir-hay and Ghur-hay would seem to correspond to the Tendwa and Ker $\bar{a} a l$ of Mr. Elliot, and are probably the $\boldsymbol{F}$. pardus and $F$. leopardus of Mr. Hodgson; and the third I had previously recognised as a particular race apparently. They undoubtedly require further investigation; and it may be remarked that all are paler and have longer fur in a cold climate. The spots of the Goral-hay are in comparatively unbroken rings, much deeper-coloured within than is the general ground-hue: those of the Kerkal are (usually) in small imperfect rosettes, with greater thickness of the black; and the Honigar or Tendwá (proper) is mostly of a-paler ground-hue than the Kerkál, with the spots arranged in larger rosettes, some of which often contain one or two small central spots : but all are subject to considerable variation; and I follow Dr. Gray in considering them as varieties (by no means well determined) of one species, according to the common acceptation of the term. The Tendwá race only (so far as I have seen) seems to exist in Lower Bengal. $\ddagger$

A.B.C. Stuffed specimens of the Honigar or Tendwá, from the Barrackpore managerie, and E. B. Ryan, Esq. (1847). D. Cub of ditto. Presented by the Curator (1848). E. Himalayan specimen. Presented by Capt. T. Hutton (1844). E. Melanoid, from Asám. Presented by Col. Jenkins (1844). F. Skeleton. Barrackpore menágerie. $H . \quad I . \quad J . \quad K$. Series of skulls. L. Flat skin of Kerkal. Presented by the Curator. $M$. Ditto of Honigar. N. Ditto of Goralhay? Presented by L. C. Stewart, Esq. (1854).

* For details, consult the Madras Journal of Literature and Science, vol. X, 106.

$\dagger$ Vide India Sporting Review, April 1856, p. 147.

$\ddagger$ There is corresponding variation in the markings of the S. American Jáguar (F. oNCA). Sir R. Schomburgh showed me two skins from Guiána, that could not be distinguished by the markings from some Indian or African Pards; but these had been selected from a great number. Again, the great variation of F. BENGALENSis (No, 178) offers an analogy to that of the present species. 
174. F. UNCIA, Schreber (Buffon, tom. IX, t. 13).

Sxn. F. pardus et $F$. onca apud Pallas.

F. panthera, Erxleben (apud Gray).

$F$. irbis, Ehrenberg.

F. tulliana, Valenciennes (Comptes Rendus, tom. XLII, 1039).

Uncia irbis, Gray.

Thurwag; Bháral-hay; Iker of Tibetans (Hodgson). Ounce or 'Snow Leopard'.

HaB. High mountains of Asia, from Tibet to the Altai, and W. even to the Taurus; never on the Indian side of the snowy ranges: Baikal and Amûr territories.

$A$. Stuffed specimen, crouched (feet wanting). Presented by G. T. Lushington, Esq. (1845). B. Flat Skin. Presented by Major Strachey (1847).

175. F. macroceloides, Fodgson, J. A. S. XII, 814, f. (P. Z. S. 185 , f. ).

SYN. $F$. macrocelis of continental India, auctorum. Uncia macroceloides, Gray.

Pungmá of the Lepchas, and Zik of the Bhoteás, of Sikhim. Lamchitia of Tibetans (Hodgson).

HAB. Lastern Nipâl ; Sikhim ; Butan ; Tibet, (Hodgson); Upper Asám; Ya-ma-doung mountains, separating Arakán from Pegu; and probably the higher elevations of the Tenasserim provinces and spine of the Malayan peninsula, if not also the moun-tains of Sumátra and Borneo, in which case doubtless identical with F. MACROCELIS, Raffles. 'Tiger-cat of Anglo-Chinese?

Remar7is. - Some individuals have a cat-grey and others a fulvous ground-hue; and the maxkings vary to some extent, occasionally even on the two sides of the same animal: the variation being fully to the extent of the alleged difference between F. MACROCELIS of Sumátra and Borneo and F. MACROCELOIDES. The former is stated to be a larger 
animal ; but vide relative size and appearance of a Bornean specimen figured as characteristic by Dr. S. Miiller, in pl. LI of his volume on 'Land-en Volkenkunde.**

$A$. Fulvous specimen from Sikhim. Presented by B. H. Hodgson, Esq. (1843). B. Grey specimen from Sikhim. Presented by E. B. Ryan, Esq. (1843). C. Flat skin (fulvous, and remarkably handsome); from the Ya-ma-doung mountains. Presented by Col. A. P. Phayre (1845). D. Specimen from Dorjiling. Presented by Dr. A. Campbell (1853).

176. F. Charltoni, Gray, Ann. $M . N . H$. XVIII (1846), p. 211.

Syn. F. marmorata of Sikhim and Asám apud nos, passim, J. A. S. XII, 1007, \&c.

Uncia Charltoni, Gray.

Hab. Higher ranges of S. Himaláya; Sikhim; Butan; Upper Asám. (Rare-but probably less so further east).

A. An injured skin, from Upper Asám. Presented by Capt. E. F. Smith, 1st Asám Lt. Infantry (1848), J. A. S. XVII, 83.

177. F. marmorata, Martin (Jardine's Nat. Libr., Feline, pl. XXI et XXII, not good).

SyN. F. Diardii, Fischer (apud Schinz), also of Jardine ut supra. $\dagger$

Uncia marmorata, Gray.

Rimau-dayan of the Malays of the peninsula.

Hab. Malayan peninsula, where common; Sumatra? A.B. Specimens from Malacca. Presented by the Rev. F. J. Lindstedt (1845).

* F. Macrocelis, in addition to F. Macroceloides, is noted from Asám by Mr. P. L. Sclater, Guide to the London Zoological Gardens (1859), p. 31. I saw the actual specimen in Calcutta, and considered it to be true MACRocElis at the time, and that macroceloides was one and the same; an opinion to which I still greatly incline.

† F. Diardii, Cuvier (Oss. Foss.), is clearly F. Macrocenis.

+ F. OGILbII, Hodgson (Caic. Joum n. N. H. VIII, 44), may here be noted as a desideratum. $N . B . F$. Ogilbii, Schinz, refers to the African F. servalina, Ogilby (vel $F$. neglecta, Gray), nec $F$. servalina, Jardine, which $=F$, orNata, Gray (No. 184). 
178. F. Bengalensis, Desmarest (after Penmant).

SrN. F. undata, Desmarest.

$F$. javanensis et $F$. sumatrensis, Horsfield.

$F$. minuta, Temminck.

F. wagati, Elliot.

$F$. pardichrous, Hodgson.

$F$. undulata, Schinz.

F. Diardii apud Griffth (An. Kings, II, 484, pl.)

F. (vel Leopardus) Ellioti, Horsfieldi, inconspicua, chinensis (?), et Reevesii (?), Gray.

F. torquata, F. Cuv. Wybrids with domestic F. nipalensis, Vigors. $\}$ Cat.

Bán Beral, Beng.; Wágati, Mahr. ; Thect Kyoung, Burm. ; Rimau ákar et Rimau bulu, Malay ; Kuwak, Jav. ' Leopard-cat' of Anglo-Indians.

Hab. A forest species, very extensively diffused over S. E. Asia; inhabiting the most elevated forests of the Himalaya, and even Tibet (Hodgson), and at all elevations down to the Bengal Sundarbáns and parts of $\mathrm{S}$. India; also the Indo-Chinese and Malayan countries, or at least the Malayan peninsula, Sumatra, Borneo, and Java ; probably also China.

Remark.-The markirigs of the fur are subject to great variations (whence the numerous synonyms). In general, the body markings much resemble those of GENETTA AFRA; but in some individuals ( $F$. wagati) they are rather those of G. PARDINA, but with a deeper fulvous ground-hue: in others, again ( $F$. javanensis), they are more like those of the next species; and rarely they assume a marbled appearance, with every possible gradation from one variety to another. Examples from the N. W. Himaláya, Asám, Bengal, Travancore, and Tenasserim, were undistinguishable as varieties (and conform with F. sumatrensis, Raffles). Hybrids produced with the European female domestic Cat resembled the sire in markings, but the ground-hue was grey and not fullvous (Pennant); and such a coloration is seen in the domestic Cat of Nipâl (Hodgson); ${ }^{*}$ the $F$. torquata, F. Cuv., and F. nipalensis, Hardw., being apparently founded on individuals of the hybrid race. As usual, specimens from a cold region have longer fur and a paler ground-hue than those of warmer regions.

* J. A. S. I, 34I. 
$A$. Specimen from the Coromandel coast. Presented alive by the Hon'ble W. Elliott, as his Wagati * (vide J. A. S., XVII, note to p. 84). B. C. $D$. E. Stand of four Himalayan specimens. Presented by Capt. T. Hutton and by the Curator (1842-6). F. G. H. I. J. Stand of five specimens, from Sikhim, Asám, and the Tenasserim provinces. Presented by G. Oakkes, Esq., C. s., Col. Jenkins, and G. O'Ryley, Esq. (1842-9). (N. B.-The marbled specimen upon this stand is from Asám. K. L. M. Stand of three specimens from the Malayan peninsula; from the Rev. F. Lindstedt and Mr. Moxon (1845). N.B.-Two of these represent the $F$. javanensis, Horsf.; and the third is $F$. sumatrana, and indeed typical bengalensis. $N$. Skeleton (of the specimen with marbled fur). $O$. Skull. Society's old collection.

N. B.-This fine series of thirteen stuffed specimens illustrates convincingly the extraordinary variation of markings observable in the species, and also the gradations from one variety to another.

179. F. Celiddogaster, Temminck (apud Gray).

SrN. F. viverrina, Bennett.

$F$. viverriceps, Hodgson.

F. himalayana, Warwick.

$F$. bengalensis apud Buch. Hamilton, $M$. S. . $^{-}$

'Tiger-cat' of Lower Bengal ; Mátch-Bágrul ('fishing Tigerlet'), and Bágh Dáshá, B.

HAB. India generally; Ceylon; Asám; Tenasserim provinces: common at the foot of the Himalaya, but does not ascend the hills.

Remark. - The skin of this animal originally described by Temminck was supposed to have been from America. The skull is remarkable for the attenuation of the nasal bones, whence a certain narrowness of visage, which has suggested the names viverrina and viverriceps; if not also the markings, which considerably resemble those of Viverricula Malaccensis, No. 143.

A. B. C. D. E. Stand of five stuffed specimens, of various ages; from the vicinity of Calcutta. $F$. Skeleton. $G$. Skull. $H$. Ditto of young kitten.

* The Wagati is referred by Dr. J. E. Gray to the next species.

$\uparrow$ In Dr. Horsfield's catalogue, the habits of this species are thus erroneously given as those of $F$. bengalensis, quoted from Hamilton's M. S. S. 
180. F. Planiceps, Vigors.

Hab. Malayan peninsula, Sumatra, Borneo. $A$. Specimen from Malacca. Presented by C. Huffnagle, Esq. (1846).*

(The second great division of Cats has constantly a more slender form of skeleton; larger and more pointed earconch, which, in general, is more or less tufted, and is mostly concolorous externally. Such are the species more immediately akin to the domestic Cat, and the Lynxes).

181. F. Serval, Schreber (F. Cuv. Mamm. Lith. I, t. 53). Srn. F. capensis, Forster.

F. galeopardus, Desmarest.

Tiger Bosch-katte, Cape colonists.

\section{HAB. S. Africa.}

$A$. Specimen from the Cape museum. Presented by E. L. Layard, Esq. (1858).

182. F. Sylvestris, Brisson (Bell's Brit. Quad. pl.)

Syn. $F$. catus of most authors, nec L.

Hab. The forests of northern and middle Europe and of middle Asia, but not Scandinavia; common in the Caucasus. N. Africa (Barbary states) $\dagger$

Remark.-As Professor Nilsson observes, this species does not inhabit Scandinavia; and the F. CATUs, L., refers to the domestic Cat of Europe, which has gone wild in Scandinavia as elsewhere.

$A$. Specimen from Scotland. Presented by Sir W. Jardine, Bart. (1843). B. Skull of the same. 183. F. catus, L. (The domestic Cat).

Billi, H. ; Berál, B.

Hab. Generally diffused; but varying in different countries, and evidently derived from a plurality of wild species in different regions, or being more or less intermingled with them.

* Desid.-F. murnensis, Hodgson, P. Z. S. 1834, p. 10: S. E. Himalaya.F. Temminckin, Vigors, Zool. Journ. Sumátra.-F. Rubiginosa, Is. Geoffroy, in Belanger's Voyage. Coromandel; Ceylon?

+ Two other N. African species alsin to the domestic Cat are-F. Manicucata, Rüppell, and F. margarita, Loche, Rev. et Mlag, de Zool. tom, X, 49, 382 , and pl. T. 
A. Wild (or feral) specimen, from the Punjab Salt Range. Presented by Mr. W. Theobald : the streaked or spotted type of Indian domestic Cat (J. A. S. XXV, 442). B. Spotted domestic Cat. Calcutta. $C$. D. Specimens of the Chaus-colored domestic Cat of India (J.A. S. XXV, 443). Calcutta. $E$. Grey Angora Cat, very faintly marked as in $A$. Presented by the Curator. $F$. Fulvous ditto, half-bred. $G$. Curiously mottled variety of Indian tame Cat. $H$. Skeleton. I. Skull of $\dot{C}$. $J$. ditto of $E$.

184. F. ornata, Gray* (Hardw. Ill. Ind. Zool.-very bad).

Srn. F. ad Oxam, Pallas (apud Gray).

F. servalina apud Jardine, Nat. Libr. (nec

$F$. servatina, Ogilby).

F. torquata of Dukhun? Sykes.

F. Huttoni, Blyth, J. A. S. XIV, 342.

Chaus servalinus, Gray.

Hab. The N. W. Provinces of Hindustân ; common in Hurriána; Hazára hills; Dukhun?

$A$. B. Skins from Hánsi. Presented by Dr. David Scott (1856-7). B. Ditto, from Hazára hills. Presented by Capt. T. Hutton (1845).

185. F. CAFra, Desmarest.

Srn. F. obscura, Desmarest, melanoid var.

Hab. S. Africa.

$A$. Specimen from the Cape; E. L, Layard, Esq. (1859).

186. F. Chaus, Guldenstadt (F. Cuv. Mamm. Lith. III, t. 32).

Srn. F. catolynx, Pallas.

F. lybica, Olivier.

F. caligata, Temminck.

F. affinis, Gray.

F. dongolensis, Hemprich and Ehrenberg.

F. Ruppelli, Brandt.

F. kutas, Pearson.

F. (Lynchus) erythrotis, Hodgson.

* Vide J. A, S. XXV, 441 , 
Syn. F. Jacquemontii, Is. Geoffroy.

Chaus lybicus, Gray.

Kátas, B. ; Kyoung tsek-koon, Arakan.

HAB. India generally; Ceylon; Asám ; Arakan ; Afghánistán; Persia; Mesopotamia; Arabia; foot of Caucasus ; Egypt and Nubia ; Barbary.

A. B. C. D. E. Specimens from vicinity of Calcutta. $F$. Ditto, from Simla. Presented by Capt. T. Hutton. G. Ditto, from Punjáb Salt Range (F. Jacquemontii). Presented by Mr. W. Theobald. H. Melanoid Skin, ${ }^{*}$ from Hansi. Presented by Dr. David Scott. I. Skeleton. J. Skull, with unusually powerful teeth, from Kábul; presented by Sir A. Burns. $K$. ditto, with ordinary teeth, from Kandahar ; presented by Captain Hutton. $L$. ditto, from Ceylon. Presented by Dr. Kelaart.

187. F. Caracal, Schreber (F. Cuv. Mamm. Lith. II, t. 34). Syn. Caracal melanotis, Gray.

Sia-gosh, Persian, Hind.; Kúra kulak, Arabia.

Hab. Central India; Arabia; Persia; Syria; Africa generally.

A. Specimen from Jeypur. Presented by Capt. Boys (1848). B. Fine male. Presented by the Curator (1859). C. Skeleton of female (1858).

188. F. Isabelinna, Blyth; J. A. S. XVII, 1178.

SYN. Tibetan $F$. lynx, auctorum.

Hab. High Central Asia; Tibet.

A. B. Adults. Presented by G. T. Lushington, Esq. (1845-8).

189. F. LYNX, L.

Syn. F. virgata, Nilsson.

Hab. N. Europe; Siberia.

A. B. Adults. Presented by the University of Christiania. C. Small young. Presented by C. S. Bonnevie, Esq. (1850), J. A. S. XX, 443 : D. Skull, ditto (1846).

* A similar melanoid variety of the affined F. CAFRA of S. Africa was named $F$. obscura by M. Desmarest. 
190. F. RUFA, Guldendstadt (F. Cuv. Mamm. Lith. III, $t .33)$.

Hab. N. America.

$A$. Skull, from N. Carolina. Presented by the Rev. F. Fitzgerald (1852).

Genus Cynailurus, Wagler.

191. C. Jubatus (Buffon, Supp. t. 38 ; F. Cuv. Mamm. Lith. II, t. 35).

Syn. Felis jubata, Schreber.

F. guttata, Hermann,

F. venatica, C. H. Smith.

Hab. All Africa; Syria; Arabia; Mesopotamia; Persia; W. and S. India ; Ceylon (apud Baker).* $A$. B. Stuffed male and female. C. Skeleton of B. Presented by the Curator (1857). $\dagger$

Sub-order PLANTIGRADA, Cuv. (as limited).

Fam. MUSTELID $\nexists$.

Sub-fam. MUSTELINAE.

Genus Gulo, Storr.

192. G. Luscus (Buffon, Supp. t. 48 : Edwards's Birds, t. 103).

* 'Eight years Wanderings in Ceylon.' By S. W. Baker (1855), p. 118. This author clearly distinguishes between the Chita and the Leopard.

+ The fine living specimen presented to the Society in February, 1858, by the Hon. W. Elliot, was afterwards given away by the then Secretary, now Sir W. B. O'Shaughnessy, who probably mistook it for a common Leopard. It is needless to remark that the Society's Zoological Curator was not consulted in the matter.

Desid. Felis Leo. Any specimens illustrative of the Lion as an inhabitant of India. I have recent intelligence that this animal still lingers in Bundellkund, in certain particularly inaccessable haunts.-F. UNCIA. Perfect skin for mounting; and skeleton, or, at least, skull.-F. MACRocelis, Raffles. Skin from Sumátra or Borneo, and skull.-M. Macroceloides. Skull.-F. Charltoni. Good skins for mounting; and skull.-F. OgILBII, Hodgson, Calc. Journ. N. H. VIII, 44 (nec F. Ogilbii, Schinz, founded on F. servalina, Ogilby, which Dr. Gray refers to his African $F$. neglecta).-F. Murmensis, Hodgson, P. Z. S. 1834, pp. 10 and 11. S. E. Himalaya; and melanoid var., Horsfield's Catalogue., ('Fire-cat' of, Tenasserim ?)-F. Temminckin, Vigors, Zool. Journ. From Sumátra.-F. Rubigir Nosa, Is. Geoff., Voy. aux Indes Or. Coromandel; Ceylon?-F. Megalotis, S. Müller. Timor.-F. onnata, Gray.-F. manul, Pallas ( $F$. nigripectus, Hodgson). Tibet; and High Central Asia.-Prionodon cracilis, Horsf. Malayan ponin. sula; Java. 
SxN. Mustela gulo et Ursus luscus, L.

Guló sibiricus, Pallas.

G. arcticus, Desmarest.

$G$. vulgaris et $G$. wolverine, Gray.

G. leucurus, Hedenborg.

HAB. Northern regions.

A. Skull from Norway. Presented by the University of Christiania (1846).

Genus Martes, Cuvier.

193. M. Abietum, Ray (Bell's British Quadrupeds, p. 170).

Sxw. Mustela martes, L.

Martes pinetorum, Ray.

M. vulgaris, Gray.

Hab. N. Europe and Asia.

$A$. Stuffed specimen; $B$. Skull taken from it. Norway. Presented by the Christiania University (1846).

194. M. Toufdeus, Hodgson, J. A. S. XI, 281.

SrN. ? Mustela foina, Brisson.

Martes fagorum, Ray.

Haв. Tibet (N. Europe and Asia?).

A. B. C. Stuffed specimens ; D. Skull, from Tibet. Presented by G. T. Lushington, Esq. (1845). E. Skull. From Sir A. Burnes's collection (1841). Afghánistân.*?

195. M. zibellina (?).

Syn. Mustela zibellina (?), Ray.

Hab. Tibet? N. Asia?

$A$. Purchased (1855).

(N. B.-A conspicuously distinct species. Paws very densely and completely clad underneath, with considerable tufts of stiff incurved bristles impending the toes. General aspect of No. 194, excepting the feet; but the colour of body much paler, and tinged with yellow; tail pale, except at tip : head whitish; the throat and front of neck yellowish-brown.)

* The specimen of a Marten (if correctly determined as such) noticed in J. A.S. V, 438, is not extant. 
196. M. flavigula (Zool. Journ. IV, t. 8).

Syn. Mustela flavigula, Boddäert.

M. Hardwickii, Horsfield.

M. leucotis, H. Smith.

Viverra quadricolor, Shaw.

Var. Martes Gwatkinsii et Galidictis chrysogaster, Jardine.

Mul-sámpra, Nipal ; Tuturál, Kumáon; Kusia, Sirmur.

Hab. Var. A. Himalaya; Khásya hills; Arakan, \&c. (Rare in Tibet? J. A. S. XI, 281.)

Var. B. Melanoid, Nilgiris.*

Var. C. (Angar Prao of the Malays). Malayan peninsula, Sumátra, and Jáva.

Var. D. Vide J. A. S. XXVI, 316.

A. Specimen from Arakan. Presented by Major Phayre (1844). B. C. Ditto from Másuri. Pre-sented by L. C. Stewart, Esq. (1855). D. Skull of female, from Asám. $E$. Ditto, female; W. Himalaya. Var. $C$. (Head faintly infuscated, with black stripe behind ear). $F$. G. Specimens from Malacca. Presented by R. W. G. Frith, Esq. (1841).

Genus Mustela, I. (limited.)

197. M. putorius, L. (Buffon, VII, t. 129 ; F. Cuv. Mamm. Lith. II, t. 38).

SrN. M. foetida, Klein.

M. furo, L. (Domestic variety, or 'Ferret').

Putorius typus, F. Cuv.

P. communis, Cuv.

P. vulgaris et foetidus, Gray.

Has. Europe; N. Asia.

$A$. B. Specimens from Scotland. Presented by Sir W. Tardine (1352). C. Skeleton. Presented by J. H. Gurney, Esq. (1860.) D. E. Stuffed Ferrets. Presented by the Máharaja of Burdwan (1858).

* The Nilgiri animal has been considered to be $M$. Grotkinsii, and is, I believe, always black throughout on the upper-parts; but it seams that the naine rather applies to the Himalayan race in summer vesture. Tide Mr. A. Leith Adams, in P. Z. S. 1858, p. 516. 
198. M. sarmatica, Pallas (Sp. Zool. XIV, t. 41), J. A. S. $\mathrm{XIV}, 346$.

SYn. M. peregasna, Guldenstadt.

$M$. precincta, Ranz.

HAв. N. and Middle Asia.

$A$. Specimen from Afghánistân. Presented by Capt. Thomas Hutton (1845). B. Skull. Burnes's collection (1841).

199. M. Lutreola (Buffon, XIII, t. 43).

SYN. Viverra lutreola, $L$.

M. vison, Brisson.

M. lutreocephala, Harlan.

Lutra minor, Exleben.

Hab. N. America.

A. Skull, from N. Carolina. Presented by the Rev. F. Fitzgerald (1853).

200. M. SIBIrica, Pallas.

Srn. M. Hodgsoni, Gray, Ann. Mag. N. H. XI (1843), p. 118.

HAB. Siberia; China; Tibet? N. W. Himalaya? $A$. Specimen from Amoy. Presented by $\mathrm{R}$. Swinhoe, Esq. ' 1859). B. Skull. Presented by Ditto.

201. M. erminea, L. (Buffon, H. N. VII, t.19, f. 2 ; XXI, t. 1).

Hab. Europe, N. and Middle Asia; Himalayas.

A. B. C. D. E. F. G. H. Specimens variously coloured, from England, Scotland, and Norway. Presented by Messrs. Davison and Kirtland, M. Malherbe, the Christiania University, \&c. (1842- 49).

202. M. subhemachalana, Hodgson, $J . A$. S. VI, 563. Syn. M. humeralis, Blyth, J. A. S. XI, 99.

Haв. Himalayas; Tibet.

$A$. B. Specimens from near Másuri. Presented by L. C. Stewart, Esq. (1855.) B. Skins from Dorjiling. Presented by Dr. Pearson (1842). 
203. M. Kathiah, Hodgson, J. A. S. IV, 102.

Syn. M. auriventer, Hodgson.

Kathiah, Nipal (Hodgson).

Hab. Himalaya (chiefly eastward); Tibet.

A. Skin received from Asám. Presented by Major Jenkins (1846).

204 M. vulgaris, L. (F. Cuv. Mamm. Lith. II, t. 39).

Srn. M. nivalis, Schreber.

Haв. Europe; Siberia.

A. B. C. D. Specimens from England. Presented by Messrs. Bartlett and Davison (1842-45).

205. M. pusilla, Dekay, Nat. Hist. N. York, I, 34 (pl. $\mathrm{XIV}$, and I ; figure infamous).

Hab. N. America.

A. B. Specimens from N. Carolina. Presented by the Rev. F. Fitzgerald (1852).*

Genus Zorilla, Gray.

206. Z. striata (Licht. Saugth. t. 48,f.2).

Syn. Viverra zorilla, Erxleben.

$V$. striata, Shaw.

Mephitis africanus, Licht.

Z. leucomelas, F. Cuv.

$Z$. capensis, Waterhouse.

HaB. S. Africa.

$A$. Specimen presented by E. L. Layard (1859).

Sub-fam. MELIDIN AE.

Genus Mellivora, Storr.

207. M. ratel (Lin. Tr. IX, t. 9).

Syn. Viverra ratel, Sparrman.

V. capensis, Schreber.

$V$. mellivora, Blumenbach.

Ursus indicus, Hardwicke.

Ursitaxus inauritus, Hodgson.

* Desid. M. Nudipes, F. Cuv. Mamm. Lithog.; Malayan peninsula; Jáva. -M. Kathiah, Hodgson ( $M$. auriventer, Hodgson).-M. Horsfieldi, Gray, Ann. Mag. N. H. 1843, p. 113.-M. LaRvata, Hodgson, J. A. S. XVIII, 446. (Patorius tibetanus, Hodgson, apud Horsfield), Tibet.-M. Canigula, Hodgson, J. A. S. XI, 269, Nipal.-M. strigidorsa, Hodgson, P. Z. S. 1853, p. 491, Sikhim.-Martes Fla vigula, vars. $B$. and $D$. 
Hab. India: Africa.

A. B. Specimens presented by the Máharája of Burdwan (1858). C. Skeleton of a male, from the Coromandel coast. Animal presented alive by the Hon'ble W. Elliot (1847). C. Skeleton of $C$. D. Skull, from Nipal. Presented by B. H. Hodgson, Esq. (1836).

\section{Genus Helictis, Gray.}

208. H. NIPALENSis, Hodgson.

SyN. Gulo nipalensis, Hodgson, J. A. S. V, 237.

H. moschatus et orientalis of India, auctorum.*

Oker of nipalese, Hodgson.

Hab. Nipal; Asám; Sylhet; Arakan, \&c.

$A$. specimen from Tippera. Presented by $\mathrm{F}$. Skipwith, Esq. (1848). B. ditto, from Arakan. Presented by Major Phayre (1843). C. Skull taken from $B$.

Genus Taxidea, Waterhouse.

209. T. Leucura, Hodgson, .J. A. S. XVI, 763.

Has. Tibet.

Tumpha of Tibetans (Hodgson).

A. Specimen presented by Dr. A. Campbell (1853). Skull wanting.

Genus Meles, Storr.

210. M. taxus (Buffon, VII, $t .7,8$; F. Cuv Mamm. Lith. II, $t .44)$.

Syn. Ursus meles, L.

U. taxus, Blumenbach.

Meles europaus et $M$. vulgaris, Desm.

Hab. Europe ; Siberia? W. and Central Asia. $†$

$A$. Specimen from England. Presented by $\mathrm{Mr}$. Davison (1846). B. Ditto, from Norway : Christiania University (1846). C. Skeleton. Presented

* Admitted as a distinct species by Drs. Gray and Horsfield; though it remains to be pointed out in what the difference consists. Desid. HeLictis sinensis, from China; and H. Moschatus, from Java, \&c.

+ The Badger of Bokhára difiers in no respect from that of Europe (Meyendorff). 
by J. H. Gurney, Esq. (1860). D. Skull, from England. Presented by Mr. Bartlett (1843).

211. M. albogularis, Blyth, J. A. S. XXIl, 590.

Hab. Tibet.

A. Specimen presented by Dr. A. Campbell (1853). Skull wanting.

Genus Arctonyx, F. Cuvier (Mamm. Lith. III, t. 60).

212. A. Collaris, F. Cuvier (Bewick's Quadrupeds, 257). SYN. Mydaus collaris, Hardw. Ill. Ind. Zool. Bhálu-soor, H.; Khway-too-wet-too, Arakan (Phayre).

Hab. Asám, Sylhet, Arakan, \&c.

A. Large male. Presented by the Máharája of Burdwán (1858). B. Old female; Arakan. Presented by Col. Phayre (1845). C. Young, from Sylhet. Presented by C. Huffnagle, Esq. (1848). D. Another. Presented by Capt. Paterson (1838). $E_{\text {。 }}$ Skeleton of a male. Presented by F. Skipwith, Esq. (1847). F. Skull of large male. $G$. Ditto from $C$.

213. A. Taxoides, Blyth, J. A. S. XXII, 591.

Hab. Asám, Sylhet, Arakan, \&c.

Adult specimen from Asám. Presented by J. McClelland, Esq. (1843.) B. young, from Arakan. Presented by Col. Phayre (1848). C. Skull of $A$.*

\section{Sub-fam $L U T R I N \not E$.}

\section{Genus Lutra, Storr. $†$}

* Desid. Mydaus melicers, F. Cuv. Malayan peninsula; Java.

+ The species of this genus are most difficult of determination, and require to be further studied and more elaborately described, with reference to their distinctions one from another. Dr. Cantor recognises three in the Malayan peninsula, viz. L. NAIk (seu indica, Gray), L. BARANG (or simung of Raffles), and L. (Aonyx) LEPTonyx. Mr. Walter Elliot and others one only in the peninsula of India, L. NAIR: and Mr. Horlgson describes four from Nipâl by the names L. monticola, L. tarayensis, L. aurivfnter, and L. (Aonyx) INDIGITATA; and even suspects (or did suspect) the existence of three others! The Indian specimens in the Society's collection have, all of them, a conspicuously white throat, abruptly demarcated on a line even with the lower part of the ears: therefore, L. BARANG is not among them; to judge from Marsden's figure of it, in which this white is shown to be ill defined, as in the European L. vUlGaRis, and in contrast with his figure of the Aonyx. My present impression of their correct synonymy, after much consideration, is given above. 
214. L. NAIR (?), F. Cuvier.

Syn. L. chinensis et L. indica, Gray.

L. tarayensis, Hodgson.

Páni Kuta, H., and Nirnai, Cuv. (Both signifying 'Water Dog'): Jul Marjar ('Water Cat'), also Hud or Hadi, Mahr.; Anjeng Ayer, Malay; Phyan, Arakan (Phayre).

HAB. India generally : Malayan peninsula (Cantor); Indo-China: China: Africa (Algeria!)*

A. Large male, from vicinity of Calcutta (fur new, much grizzled throughout with hoary tips). Presented by W. H. Greenfield (1848).-B. Ditto, female: vicinity of Calcutta (fur ungrizzled, the tips having worn off, or, rather, been naturally shed (1842).-C. Specimen from Murshedabad (rather rough-coated). Presented by J. W. Laidlay, Esq. (1845). - D. Specimen from Algeria (!), quite undistinguishable from $C$ ). Presented by M. Alfred Mahherbe (1849).-E. $F$. Young, from vicinity of Calcutta (1845-57).-G. Half-grown specimen, with deciduary canines (the throat deeply tinged with orange-brown): from S. India. Presented by the Hon'ble W. Elliot as the nair of his catalogue.$H$. Skeleton of $B .-I$. Skull of male : Bengal.-J. Ditto; Deyra Doon. Presented by L. C. Stewart, Esq.-K. Ditto, from Travancore: taken from a skin. Presented by the Hon'ble W. Elliot (and considered by him as probably distinct from the $L$. nair of his catalogue.-I. Another skull, from Travancore or Cochin. Presented by the Rev. H. Baker, Jr. (1859).-M. Skull from Arakan (small foremost upper præ-molars naturally wanting, as in Aonyx.) Presented by Col. Phayre (1845).

* The common large Otter of the plains of India, which is extensively tamed and trained for fishing in the Bengal Sundarbáns, and along the course of the Bráhmaputra river, by driving the fish into the fishermen's nets : not as Cormorants are trained in China. N.B.-The pale facial spots mentioned by F. Cuvier are, at most, indistinct; or, as Baron Cuvier remarks in the Régne Animal, "a quelque chose de pâle aux sourcils, mais á peine sensible." A flat skin received from China (Amoy) is undistinguishable from that of the common Otter of Bengal. 
215. 1

SrN. I. nair apud Layard et Kelaart.

Haв. S. India (?) : Ceylon.

A. Specimen from Ceylon. Presented by E. L. Layard, Esq. (1848). B. Another, from Newera Ellia (4,500 feet elevation). Presented by Dr. E. F. Kelaart (1848).

216. L. vulgaris, Erxleben (Buffon, VII, $t .11$ ).

Syn. Mustela lutra, L.

L. röensis, Ogilby.

Hab. Europe; N. Asia.

A. Specimen from the Christiania University (1846). B. Ditto from England. Presented by Mr. Davison (1844). C. Large skull from Derbyshire. Presented by Dr. D. Scott (1856). D. Skull taken from $A$. $\mathbb{E}$. skull from a Himalayan specimen referred to L. MonTICOLA, Hodgson: undistinguishable from that of L. VULGARIS; being much more compressed between the orbits than in I. NAIR.

Sub-genus Aönyx, Lesson.

217. L. leptonyx, Horsfield (Zool. Res. in Java, fig.)

SxN. I. barang apud Schinz.

I. barany et Aönyx leptonyx apud Cantor (Horsfield).

L. indigitata, Hodgson.

Aönyx Horsfieldii, Gray.

Hab. Himalaya; Indo-China; Malayan peninsula and archipelago.

A. Adult (very dark); B. young (brown); from Malacca. Presented by R. W. G. Frith, Esq. (1847). C. D. Specimens from N. W. Himalaya : purchased (1851). E. Specimen (more chesnut), from Arakan. Presented by Col. Phayre (1844). F. Another (very chesnut-coloured: fur old). From Dorjiling. Presented by Mrs. Saxon (1844). G. Skull from $\mathbb{F}$. H. Skull from Másuri. Presented by $\mathrm{L}$.

* Very like the last, but specimens with adult dentition smaller by one.. half or nearly so: also found at greater elevations. 
C. Stewart, Esq. (1843). I. Portion of ditto, from $A$. J. $K$. Skulls from Society's old collection (more compressed between the orbits, and perhaps distinct. (Query, L. InUNGurs, F. Cuvier, - v. Delalandi, of S. Africa?).

Sub-order PLANTIGRADA, Cuv. (as limited).

Genus Cercoleptes, Illiger.

218. C. Caudivolvulus (Buffon, Supp. III, t. 50, 51).

Syn. Viverra caudivolvula, Pallas.

C. megalotis and C. brachyotis, Martin.

Lemur flavus, Schreber.

' Yellow and Mexican Weasel,' Pennant.

'The ' Kinkajou;' Maniviri, Humboldt.

Hab. Tropical America.

$A$. Skeleton. B. Imperfect skin. Received from Mr. Bartlett (1849).

Genus Arlurus, F. Cuvier.

219. A. Fulgens, F. Cuv. (Lin. Tr. XV, t. II ; F. Cuv. Mamm. Lith. III, $t$. 52).

Srn. A. ochraceus et fulgens, Hodgson, J. A. S. XVI, 1118, XVII, 476 and 573.

Wáh, Oá, Ukhtónka, Saknam, Thóngwah and Thó-kye; also Yé, and Négálya pónya of the Tibetans, Nipalese, and Sikimites, (Hodgson). Wá, and Chitwá, (Hardwicke). Panda (F. Cuvier).

HAB. "The declivities of the Sub-Himalayas, north and south, between 7,000 or 8,000 , and 12,000 or 18,000 feet of elevation." (Hodg.son.)

A. B. C. Stuffed specimens, illustrative of variation of colour. Presented by Dr. Campbell (1836), J. A. S. V, 758 ; E. T. Lushington, Esq., and Mrs. Oakes (1843, 1847). D. Skull.

Genus Procyon, Storr.

220. Pr. Lotor (Buffon, VIII, t. 43 ; F. Cuv. Mamm. Lith. I, t. 69). 
SyN. Ursus lotor, L.

Lotor vulgaris, Tiedemann.

Meles alba, Brisson (albino).

Hab. N. America.

A. Specimen received from Mr. Bartlett (1849). $B$. Skull, from ditto. $C$. Another. Presented by the Rev. F. Fitzgerald (1853).

Genus Nasua, Storr.

221. N. NARICA (F. Cuv. Mamm. Lith. I, t. 67, 68).

SYN. Viverra narica, L.

$V$. quasge, Gmelin.

$N$. obfuscata, Illiger.

N. fusca, Desmarest.

HAB. Tropical America.

A. Stuffed specimen (tail imperfect). B. Skull. Presented by Mr. Bartlett (1849).

Genus URsus, L.

$$
\text { Reech, H. ; Bhálu, B., \&c. }
$$

(Sub-genus Thalarctos, Gray.)

222. U. maritimus, L. (Cuv. Menag. Mus. I, t. 72).

SrN. U. marinus, Pallas.

U. polaris, Shaw.

U. albus, Brisson.

HaB. Arctic regions.

A. Skull, from Greenland; from the Royal Copenhagen Museum (1839).

(Sub-genus Ursus, Gray.)

223. U. arctos, L. (Buffon, VIII, t. 31 ; F. Cuv. Mamm. Lith. I, t. 70, 71, III, t. 54, 55).

SYN. U. pyrenaicus, norvegicus, et colla-

$U_{\text {. fis, F. Cuvier. }}$ formicarius et cadaverinus, $\}$ apud Gray.

Eversmann.

HAB. Europe ; Siberia ; 'Barren-grounds' of Arctic America (apud Richardson).

$A$. B. Skulls of male and female, from Norway: Christiania University (1846). 
224. U. ISABELlinus, Horsfield.

SYN. U. syriacus (?), Hemp. et Ehrenberg (apud Gray). Brown, Red, Yellow, White, Grey, Silver, or Snow Bear of Himalayan sportsmen : Ilarput, Kashmir.

HAB. Tibet; Snowy region of Himalaya; and High Central Asia generally?

$A$. Stuffed specimen, and B. C. Skins. Presented by G. T. Lushington, Esq. (1847.) $D$. Stuffed specimen. Presented by the Máharaja of Burdwán (1858). E. Skull of aged male (lower jaw wanting). Presented by Dr. A. Campbell (1856). F. Skull of female from Kashmir. Presented by Lieut. Brownlow (1856).* G. Enormous skull, from Kashmir: purchased (1858).

(Sub-genus Helarctos, Horsfield).

225. U. tibetanus, F. Cuv. (Mamm. Lith. III, t. 56).

SrN。U. malayanus of Asám, apud Walker.

$U$. ferox apud Robinson ('Account of Asám').

' Black Bear' of Himalayan sportsmen.

HAB. Forest region of Himalaya. Very rare in Tibet (forests of Eastern Tibet?).

$A$. Stuffed specimen from Asám. Presented by Col. Jenkins (1847). B B. Skull taken from $A$. $C$. Imperfect skin of rare Tibetan variety, designated the 'Blue Bear' (vide J. A. S. XXII, $589)$.

226. U. Malayanus, Raffles (F. Cuv. Mamm. Lith. III, t. 58).

Syn. U. euryspitus, Horsfield (individual variety from Borneo, figured in Zool. Journ. I, pl. 7). Bruang, Malay; Wet-woon, Arakan.

* Presented as the 'Isabella Bear' of Ladakh; but the word 'Kashmir' is marked on the skull. N. B.-In Dr. J. E. Gray's Brit. Mus. Catalogue, a skull is noted from the "Northern Circars!" Possibly, however, that of a tame animal that had been led about the country; as one that, for many years past, has been occasionally led about the streets of Calcutta, being the individual noticed by Dr. H. Walker, in Calcutta Journ. N. H. III, 268. 
HAB. Arakan; Indo-Chinese countries generally; Malayan peninsula, Sumátra, Jáva, and Borneo.

A. Specimen from Jáva. Presented by Capt. Scholefield, J. A. S. XVII, 250. B. Another, from Arakan. Presented by Major Phayre (1845). C. Young. Presented by H. W. Bennett, Esq. (1853). D. Skull of $B$. $E$. Skull of $C$.

(Sub-genus Prochilus, Vigors.)

227. U. Labiatus, Blainville (F. Cuv. Mamm. Lith. III, t. 57).

SyN. Bradypus ursinus et ursiformis, Shaw.

Ursus longirostris, Tiedemann.

$U$. torquatus, Schinz.

Melursus lybius, Meyer (apud Gray).

Bállu or Rikshá, Sanskr. (Wilson); Reech, H. ; Bhálu or Bhálūk, B. ; Elugu, Telugu; Aswail, Mahratta; Kaddi or Karadi, Can. ; Rinch, Dukhuni.

HAß. India generally; Ceylon : rare in Asám ?

A. Stuffed male. B. Young, presented by the Máharája of Burdwán (1858). C. very young, Presented by the Curator (1854, $D$ Small skeleton, mentioned $J . A . S$. VII, 987. E. F. G. H. I. J. Fine series of six skulls. Presented by Dr. McCosh and others.

\section{PINNIGRADA.}

Fam. PHOCID $\mathbb{E}$.

Sub-fam. PHOCIN AE.

Genus Callocephalus, F. Cuvier.

228. C. vitulinus (F. Cuv.,Mamm. Lith. I, t. 74, III, t. 61). Syn. Phoca vitulina, L. (?), Nilsson.

Ph. littorea, Thienemann.

Ph. canina, Pallas.

Ph. communis, L.

Hab. Europe and North America. 
A. Stuffed albino. Presented by the Montrose Institution (1846). $B$. Half-grown specimen, stuffed. Presented by Mr. Bartlett (1844). C. Skeleton. Presented by J. H. Gurney, Esq., M. P. (1860). D. E. Two skulls of males, and young, from Greenland. From the Royal Museum of Copenhagen (1839), J. A. S. VIII, 968.

229. C. annellatus (Phoque commun gris, F. Cuv., Mamm. Lith. I, t. 73).

Syn. Phoca annellata, Nilsson.

Ph. Frederici, Lesson.

Ph. Schreri, ibid.?

Ph. equestris, Pallas.

Ph. foetida, Muller.

C. discolor, F. Cuv. apud Gray.

C. hispidus, F. Cuv., apud Schinz.

Hab. Northern regions.

$A$. Skull of adult male, from Greenland. From the Royal Museum of Copenhagen (1839), J. $\boldsymbol{A}$. S. VIII, 968.

230. C. Grenlandicus.

SYN. Phoca gronlandica, Müller.

Ph. oceanica, Lepeche.

Ph. semilunaris, Boddäert.

Ph. dorsata, Pallas.

Ph. Mulleri, Lesson.

Ph. laguros, Cuvier.

Ph. albicauda, Desmarest.

Ph. Desmarestii et Ph. Pilayi,

Lesson.

' Harp Seal,' Pennant.

HAB. Northern Ocean.

$A$. Skull of old male. B. Ditto of adult female, from Greenland. From the Royal Museum of Copenhagen (1839), J. A. S. VIII, 968.

Genus Phoca, L. (restricted).

231. Ph. barbata, Fabricius.

SYn. Ph. leporina, Lepeche.

Ph. nautica, Pallas.

Ph. albigera, ibid. 


\section{' Great Seal,' Pennant.}

Hab. Europe.

$A$. Skull of adult female, from Greenland. From the Royal Museum of Copenhagen (1839), J. A. S. VIII, 968.

Sub-fam. TRICHECHINAE.

Genus Trichechus, L.

Tr. rosmarus, L. (Proc. Zool. Soc. 1853, p. 116).

232. Syn. T. obesus et $T$. divergens, Illiger.

Rosmarus arcticus, Pallas.

' Morse' or 'Walrus'.

Hab. Northern Ocean.

$A$. B. Skulls of male and female, from Greenland. From the Royal Society of Copenhagen (1839), J. A. S. VIII, 969. C. Tusk of female.

Sub-fam. CYSTOPHORINAE.

Genus Cystophora, Nilsson.

233. C. Cristata, Nilsson.

Syn. Phoca cristata, Dekay.

Ph. mitrata, Milbert.

Ph. leucopleura, Thienemann.

$P h$ leonina, L., Muller.

Ph. cucullata, Boddäert.

C. borealis, Nilsson.

Hab. Northern Ocean.

$A$. Skull of old male. B. Ditto old female $C$. Ditto young male. D. Ditto six months old. From the Royal Museum of Copenhagen (1389), J. A. S. VIII, 968-9.

Genus Morunga Gray.

234. M. proboscidea (Peron, Voy. Terr. Austr. t. 12 ;

Cuv. Oss. Foss. V, 213, t. 18 and 19).

Syn. Phoca proboscidea,

Ph. Ansoni,

Ph. Coxii,

Ph. leonina, L.

Ph. elephantina, Molina.

Ph. dubia, Fischer.

'Sea Elephant.'

Desmarest. 
MAB. S. Ocean.

A. Upper canine. Presented by Mr. C. K. Hamilton (1860.)

Order INSECTIVORA, Cuvier.

Fam. Erinaceida.

Genus Erinaceus, L.

234. E. megalotis, Blyth, J. A. S. XIV, 353 ; XV, 170.

HaB. Afğhánistân.

A. Specimen from Kandahar. Presented by Captain T. Hutton (1845).

235. E. vulgaris, L. (Bell's 'British Quadrupeds', pl).

SYN. E. inauris (?), L.

E. auriculatus, Hill.

$\boldsymbol{E}$. caninus et $\boldsymbol{E}$. suillus, Geoffroy.

E. sibiricus, Bell.

E. europceus, Gray.

Hab. Europe ; N. Asia.

A. B. Stuffed specimens. C. D. Skulls. England. Presented by Mr. Bartlett (1843). E. Skeleton. Presented by J. H. Gurney, Esq. (1860).

236. E. coliaris, Gray (Hardwicke's Ill. Ind. Zool).

Hab. N. W. of India (Punjab, Sindh, Buháwulpur).* $A$. B. Stuffed specimens, and $C$. Skull; from Pind Dádun Khán. Presented by Mr. W. Theobald (1859).

237. E. MiCropus, Blyth, J. A. S. XV, 171.

SYN. E. nudiventris, Horsfield.

E. auritus (?), apud Pearson, J. A. S., V, 191.

Hab. Nilgiris; mountains of Ceylon?

$A$. Stuffed specimen, and $B$. Skull of ditto. Presented by W. H. Smoult, Esq. (1836). C. Skull, presented by Walter Elliot, Esq., Madras C. S. $(1843) \cdot \uparrow$

* "Dukhun; Sindh; Punjab ; and lower Himalayan ranges: common." Proc. Zool. Soc. 1858, p. 520.

$\dagger$ Desid. E. Mentalis, Gray, Br. Mus. Catal. (undescribed). Himalaya.-E. Grayi, Bennett, P. Z.S. 1832, p. 124. "India."-E. spatangus, Bennett, P. Z. S. 1834, p. 124. (E. Grayi, jun ?). "India."-" Two species in Ceylon"; Nos. 25, 26, Kelaart's Catalogue, Proc. Zool. Soc. 1850, p. 156; et Prodromus Faune Zeylanica (1852), p. 38 . 
Genus Grminura, Raflles.

238. G. RAFFlesir, Vigors and Horsfield.

Syn. Viverra gymnura, Raffles.

Tikus ambeng bílan, Malay.

HAB. Malayan peninsula; Sumatra; Mergui ?*

$A$. Half-grown specimen from Malacca; presented by C. Huifnagle, Esq. (1846).

Genus Tupaia, Raffles.

239. T. tana, Raffles (Horsfield's Zool. Res. in Java, pl.; and head by Dr. S. Müller).

Syn. Cladobates speciosus, Wagner.

Нав. Sumatra. $(1845)$.

240. T. Ferruginea, Rafles (Horsfield's Zool. Res. in Java, pl. ; and head by Dr. S. Müller).

Syn. Cladobates javanicus, Lesson.

Hylogale javanica, Temminck.

IHylogalea javanica, Schlegel and Müller.

Hierpestes, Calc. Journ. Nat. Hist. II 458.

Var. Tupaia peguana, Lesson, et Cladobates Belangeri,

Wagner (Zool. de Belanger, Voy. t. 4).

Tupai Press apud Raffies and Horsfield; Tupai tana of the Malays of Pinang; Tswai, Arakan.

IAB. Sikhim (? rare); Khásya hills ; Arakan; Pegu ; Tenasserim provinces; Malayan peninsula; Sumátra; Jáva; Borneo.

Remark.-Tenasserim specimens are darker and less deeply tinged with ferruginous than are those from the Malayan peninsula and archipelago ; while those from Pegu, Arakan, and the Khásya hills (T.peguana v. Belangeri,) are paler and but slightly tinged with ferruginous.

A. B. C. Specimens from Pinang and Malacca. Presented by the Rev. J. Barbe and the Rev. F.T. Lindstedt (1846). D. E. Ditto, from Mergui. Presented by Capt. Berdmore (1856); and $F$. Skull. G. H. Ditto, from Arakan; and I. Skull. Presented by Colonel Phayre (1844). J. Specimen

* Probably the "Opossum" of Col. Low. Journ. Roy. As. Soc. III, 50, and $A$ s. Res. XVII, 159. It is also doubtfully mentioned as having been received from Arakan, Calc. Joum. Nat. Hist. II, 147 ; probably by mistake. 
in spirit, from Pegu. Presented by Capt. Berdmore (1856.) $K$. Skeleton of one sent alive from Cherra Punji. Presented by R. W. G. Frith, Esq., 1851.)*

241. T. Ellioti, Waterhouse, P. Z. S. 1849 , p. 106 ; J. A. S. XX, 519. Vide J. A. S. XX, 185.

HAB. Coromandel coast; Central India?; Ceylon? A. B. C. Stuffed specimens, and D. Skull. Presented by Walter Elliot, Esq., Madras C. S. (1851).

242. T. Javanica, Horsfield (Zool. Res. in Java; and head by Dr. S. Müller).

Bangsring, Sinsring, and Emes, Java.

HAв. Malayan peninsula; Sumátra; Jáva; Borneo. A. B. Specimens from Malacca, and C. Skull. Presented by Mr. Frith (1846).

Genus Hylomys, S. Müller.

243. H. PeGUensis, Blyth, J. A. S. XXVIII, 294.

НАв. Valley of the Sitang river, Tenasserim provinces.

$A$. B. Specimens in spirit. Presented by Major Berdmore (1858).

Genus Sorex, L.

244. S. carulescens, Shaw (Hardw. Ill. Ind. Zool., pl.) Sry. S. pilorides, Shaw.

S. indicus et S. capensis, Geoffroy.

S. giganteus et S. Sonneratii, Is. Geoffroy.

S. crassicaudatus, Lichtenstein.

S. myosurus apud Gray, Hardw. Ill. Ind. Zool. ; and probably of Walker, Calc. Journ. N. $H .$, III, 255.

Chichundr, H.; Sika, Asám. Common 'Musk Rat' of Anglo-Indians.

HAB. India generally; Ceylon; Tenasserim provinces; Indonesia? China? Japan? Africa? Madagascar?

* A species of Tupaia, probably this one has recently been obtained by Dr. Jerdon at Dorjiling. 
A. B. Stuffed specimens. C. Skeleton of female, and $D$. Skull of male. Calcutta. $E$. Young, from Tenasserim. Presented by Mr. W. Theobald, Junr. (1855).

245. S. albinus, Blyth, $J$. A. S. XXIX, 90.

Hab. China (Amoy).

$A$. Young. Presented by R. Swinhoe, Esq. (1859).

246. S. MURINUS, L.

SYN. S. myosurus, Pallas.

S. cerulescens, var., Raffles.

S. Swinhoei, Blyth, J. A. S. XXVIII, 285 ; XXIX, 89 (young).

S. viridescens (?), Bl., J. A. S. XXVIII, 285. Chinchorot, Malay.

HAB. Malay countries; China; rare in Lower Bengal; S. India (Malabar).

$A$. B. Specimens from vicinity of Calcutta (1859). $C$. D. Ditto, from Amoy. $E$. Skin in spirit from Amoy. Presented by R. Swinhoe, Esq. (1859). $F$. Imperfect flat skin described as S. viridescens, from Malabar ; $\boldsymbol{G}$. H. Stuffed specimens from Malabar. Presented by Rev. H. Baker, Junr. (1859).

247. S. Griffithir, Horsfield, Catal.; Tomes, Ann. Mag. N. H., 2nd series, XVII (1856), 17.

Syn. S. murinus apud nos, J. A. S. XXIV, 28.

HAb. Khásya hills; Sylhet; Arakan (not Afghánistân, as stated by Dr. Horsfield*).

$A$. Stuffed specimen. B. Entire specimen in spirit. Both from Cherra Punji. Presented by F. Skipwith, Esq. (1846). C. Another in spirit. From Arakan. Presented by Col. Phayre (1845).

248. S. Serrpentarius, Is. Geoff. (vide J. A. S. XXI, 350, XXIV, 30, XXVIII, 284).

Syn. S. kandianus, Kelaart.

* The late Dr. Griffith collected both in the Khásya hills and in Afghánistân ; and his specimens from these two very distinct localities became intermixed and confounded. Hence severaI Khásya species of mammalia, birds, and reptiles, have been erroneously stated to inhabit Afghánistân. 
Hab. Mergui ; Ceylun; Coromandel coast; Mauritius?

$A$. Stuffed specimen from Kandy, and B. Skull. Presented by Dr. Kelant (1852). C. Ditto, from Mergui, and $D$. skull. E. Specimen in spirit, from Mergui. Presented by Major Berdmore (1853).

249. S. soccatus, Hodgson (vide J. A. S. XXIV, 30, XXVIII, 285).

Hab. Nipâl and Sikhim; Másuri.

$A$. Stuffed specimen, and $B$. Skull, from Dorjiling. Presented by Major W. S. Sherwill (1854).

250. S. heterodon, Blyth, J. A. S. XXIV, 30.

Haв. Khásya hills.

$A$. Stuffed specimen, and $B$. Skull, from Cherra

Punji. Presented by R. W. G. Frith, Esq. (1855).

251. S. NIGER, Elliot (Horsfieln's Catal.); Tomes, Ann. $M$. N. H., 2nd series, XVII (1856).

HAB. Nilgiris; Malabar?

A. Specimen presented by the Rev. H. Baker (?) (1858).

252. S. kelaArti, Blyth, J. A. S. XXIV, 32.

Hab. Ceylon.

A. Specimen in spirit, from Galle. Presented by Dr. Kelaart (1854).

253. S. Fuliginosus, Blyth, J. A. S. XXIV, 262.

HAB. Tenasserim provinces.

A. B. Specimens in spirit. C. Ditto, stuffed.

$D$. Skull. Presented by Major Berdmore (1855).

254. S. NUdipes, Blyth, J. A. S. XXIV, 34.

Syr. S. Peyroteltii apud Bl., J. A. S. XVI, 1275.

Has. Burmese countries.

A. B. C. D. E. Specimens in spirit, and $F$. Skull ; from Amherst. Presented by E. O'Reilly, Esq. (1847); and from Tenasserim. Presented by Major Berdmore (1856).

255. S. melanodon, Blyth, J. A. S. XXIV, 33.

Hab. Lower Bengal. 
$A$. Specimen in spinit, procured in Calcutta (1855); B. Another (bad). Calcutta (1857).

256. S. atrates, BIyth, J. A. S. XXIV, 34 (S. nudipes, var. ?).

Ha B. Kìshya hills.

$A$. Headless specimen in spirit, from Cherra

Punji. Presented by Mr. Frith (1851).

257. S. Hodganon, Blyth (S. Perrottetii? Duvaucel), J. A. S. XXIV, 34.

Syn. S. pygmens, Hodgson (nec Pallas), Ann. $M$. N. H. XV (1845), p. 269.

Нав. Sikhim. Nilgiris?

A. Specimen in spirit, from Dorjiling. Presented by Major Sherwill (1854).

258. S. Micronyx, Blyth, J. A. S. XXIV, 33.

Hab. N. W. Himalaya.

A. Dried specimen, from Almorah. Presented by Major R. Wroughton (1846); $B$. Ditto in spirit̀, from Másuri. Presented by L. C. Stewart, Esq. (1852).

259. S. araneus, Schreber (Ann. Mus. XVII, p. 2.)

Sys. S. rusulus, Zimmerman.

S. pacizzurus, Kuster.

S. poliogaster,

S. major,

S. fimoriata,

S. moschata,

S. inodorus, Savi.

Wagler.

HАв. Europe (nec Britain).

A. Specimen from France. Presented by M. Malherbe (1849).**

* Desid.-S. Trtuenr, Blyth; J. A. S. XXVIII, 285. Dehra doon.-S. satuRation, Hodgson, Am Mlag. N. M., 2nd series, XVI (1855), 110. Nipâl.-S. Nemolivagus, Hodgson, J. A. S. XXIV, 30. Nipâl.-S. Leucors, Hodgson, Ann. M. N. H., 2nd series, XVI (1855), 111. Sikhim.-S. Pernoteti, Duvernoy, Guérin, Mag. de Zool., 1842, livr. 8 ; Ann. M. N. H., 2nd serics, XVII (1856), 21. Nilgiris.-S. purpurascens, Templeton, Ann. M. N. I. XV (1855), 239, Ceylon.-S. nontavus, Kelaart, Amn. M. N. H, 2nd series, XVII (1856), 19, Ceylon. S. Ferrugineus, Kelaart; S. montamus apud nos, J. A. S. XX, 185 ; ibid. 153, et vide Ann. M. N. H. XVII (1857), 19. Ceylon.-Corsira newera-eldia, Kelaart, v. C. nigrescens, Gray, var., Proc. Zool. Soe. 1850, p. 158. Mountains of Ceylon. 
Genus Soriculus, Blyth (Blaria? Gray).

260. S. nigrescens (vide $J$. A. S. XXIII, 733; XXIV, $36)$.

Syn. Corsira nigrescens, Gray.

Sorex sikimensis, Hodgson.

S. aterrimus, Bl., J. A. S. XII, 928.

HAB. Nipal; Sikhim.

A. B. C. Stuffed specimens. D. E. F. Ditto in spirit. From Dorjiling. Presented by Major W. S. Sherwill and Mr. W. Theobald, Junior (1854-5).

Genus Corsira, Gray.

261. C. alpinus.

Srn. Sorex alpinus, Schinz.

S. caudatus, Hodgson, vide Tomes, Ann. M.N. H. 2nd series, XVII (1856), p. 27.

H.ı. European Alps; Hinnalaya (Sikhim).

$A$. Stuffed specimen, from Mt. St. Gothard. Presented by Mr. Malherbe (1849). B. Example in spirit, from Sikhim. Presented by. W. T. Blanford, Esq. (1858).

262. C. vUlGaris (Bell's British Quadrupeds, p. 109).

Syn. Sorex vulgaris et $S$. araneus (apud Gray), L., nec S. araneus, Schreber).

S. tetragonurus, Hermann.

S. constrictus, Geoffroy.

S. Hermanni, Hollandre.

S. melanodon, S. concinnus, et

S. rhinolophus, Wagler.

S. labiosus et S. eremita, Bechstein?

S. araneus of British authors, until recently.

Var. S. Daubentonii, Baillon.

Hab. Europe, from Scandinavia to Italy, British islands, \&c.

$A$. Specimen in spirit, from Norway. Xia University (1844). $B$. Ditto from France, sent as S. Leucodon, by M. Malherbe (1854), J. A.S. XXIII, 212. C. Ditto, stuffed; France, M. Malherbe (1854). D. E. Ditto from England; and $F$. Skull. Presented by Mr. Davison (1846). 
Genus Crossopus, Wagler.

263. Cr. Fodiens (Bell's Brit. Quadr. p. 115).

Sy N. S. fodiens et S. hydrophitus, Pallas.

S. Daubentoni, Erxleben.

s. Hermanni, Duvernoy.

S. licolor, Shaw.

S. Aluviatilis, Bechstein.

S. constrictus, Hermann.

S. stagnatilis et $S$. rivalis, Brehm.

S. musculus et S. psilurus. Wagler.

Amphisorex Pennantii, Gray.

Hab. Europe generally; N. Asia (Siberia).

$A$. Specimen in spirit, from Norway. Presented by the Xia University (1846).*

Genus Astromydes, Harris.

264. A. CRistatus (Pennant's 'Quadrupeds,' II, 90, f. 2). Syn. Sorex cristatus, L.

S. radiatus, Shaw.

Talpa canadensis, Traill.

T. longicaudata, Erxleben. >apud Gray.

Condylura cristata, Desmarest.

C. prasinata, Harris.

C. macroura, Harlan.

Hab. N. America,

A. Stuffed specimen, from Mr. Bartlett (1843).

Genus Scalops, Cuvier.

265. Sc. Aquaticus, Fischer.

SyN. Sorex aquaticus, L.

Scalops canadensis, Cuvier.

Talpa fusca et T. purpurascens, Shaw.

Hab. N. America.

$A$. Specimen in spirit, from N. Carolina. Presented by the Rev. F. Fitzgerald (1853).

Genus Chrysochloris, Cuvier.

266. C. holosericea, Lichtenstein (Brown, Ill. Zool. $p l$.) Syn. C. hottentota, A. Smith.

Hab. S. Africa.

* Desid. Cr. himalaicus, Gray, Ann. M. N. H., X (1842), p. 261 ; also Tomes, ibid., 2nd series, XVII (1856), p. 26.-Feroculus nackolus, Kelaart; Sorex feroculus, K., J. A. S. XX, 163. Ceylon. 
A. B. Stuffed specimens. Presented by E. L. Layard, Esq. (1859).

267. C. Damarensis, Ogilby, P. Z. S. 1838 , 1. 5.

IIB. S. Africa.

A. Specimen. Presented by Major W. S. Sherwill $(1852)$.

Genus Talpa, L.

268. T. Eunopea, L. (Bell's 'British Quadrupeds,' fig.)

Syn. rit. vallyaris, Brissoil.

IAs. Enrope generally (not Ireland, nor Sardinia). A. Stuffed specimen. Presented by Mr. Bartlett (1843). B. C. Skeletons; one presented by Mr. W. Masters (1844).

269. T. monouna, Hodgson (skull figured $J . A . S$. XIX, 217).

Hab. Nipal; Sikhim; Asám.

A. Specimen in spirit, from Nipal. Presented by Mr. Hodgson (1843). B. Ditto, from Dorjiling; purchased (1842).* C. Ditto, and D.E.F. Stufted specimens, from Asám. Presented by Col. Jenkins (1854). G. H. I. Ditto, from Dorjiling. Presented by Mrs. Oakes (1854). J. Skeleton. Presented by W. T. Blandford, Esq. (18.57).

270. T. Lwucura, Blyth (skull figured $J$. A. S. XIX, 217). Haß. Sylhet; Káshya hills; Tenasserim provinces. A. B. C. Stuffed specimens. Presented by $\mathrm{Mr}$. Skipwith and Mr. Frith (1840-51). 1). Specimen in spirit. Presented by Mr. Frith. E. Specimen in spirit from the hilly region bordering on the Sitang river, Tenasserim. Major Berdmore (1848), $\boldsymbol{J}$. $\boldsymbol{A}$. S. XXVIII, 294. $F$. Skeleton. Ditto (1851).†

- (?) IsODONTIA.

Order CETACEA.

Family DELPHINID IE. Sub-family DELPHININ ZE Genus Phocжna, Cuvier.

271. Ph. communis, Lesson (F. Cur. Mamm. Lith. IIT, $t$. 117 ; Cuv. Oss. Foss. V, t. 21, f. 1, 2, skull).

* T. crypturce, J. A. S. XII, 929.

$\uparrow$ Desid. T. macroura, Hodgson, Nipâl. J. A. S. XXVII, 176-T-? J. A. S. XXVIII, 286. Nilgiris ; Malabar. 
Srx. Delphinus phocana, L.

Ph. Rondeletii, Willoughby.

HAB. Northern Atlantic.

$A$. B. Skulls, from Greenland; from the Royal Museum of Copenhagen (1840), J. A. S. VIII, 969. C. Skeleton. Presented by the Royal University of Christiania (1846), J. A. S. XV, Proc. IX.

Genus Neomeris, Gray.

272. N. PHocenoides (Fauna Japon. t. 25, 26, Gray's Brit. Nus. Cat.pl. IV, f. 2).

Srr. Delphinus phocenoides, Dussumier. $\}$ apud D. et Delphinapterus melas, Temminek. $\}$ Gray.

HAs. Indian Ocean ; Bay of Bengal ; Japan (Tem.); C. G. Hope or Malabar (Dussumier).

$A$. Skeleton of adult male. From the Calcutta fish-bazaar (July 26th, 1860), J. A. S. XXIX.

Genus Globicephalus, Lesson.

273. GL. Deductor (Scoresby, Arct. Reg. I, 496, t. 13,f. 1).

Syn. Delphinus deductor et D. melas, Traill.

D. globiceps, Cuvier.

D. grampus, Cat. Mus. Coll. Surg., No. 1137 (apud Gray).

Cachelot svineval, Lacepéde.

Gl. svineval, Gray, Zool. 'Erebus' and 'Terror.' Cáing Whale.

Hab. N. Atlantic.

A. skull from Greenland. From the Royal Museum of Copenhagen (1840), J. A. S. VIII, 69.

274. GL. Indicus, Blyth, J. A. S. XIX, 425, XXI, 358, XXVIII, 490.

"Black-fish" of sea-men (Bay of Bengal).

HAB. Bay of Bengal; occasionally ascending (in or about July) the Gangetic rivers.

$A$. B. Skeletons of adult male and female (the latter mounted); from a great shoal-'schule' or 'school'-which found their way into the salt-water lake near Calcutta in July, 1850. C. Stuffed specimen of a young animal, $6 \frac{1}{2}$ feet in length, which was procured in the Hágli near Serampore, 
and presented by C. T. Lushington, Esq. (1852). $D$. Skeleton of a newly born female, procured in the Calcutta fish-bazar (1859).

Genus Beluga, Raffinesque.

275. B. catodon (Pallas, Reise III, 2 to 7 ; Bell's $B r$. Quadr., p. 491, f.)

Srn. Physeter catodon, L. (apud Gray).

Ph. macrocephalus var? catodon, Fischer.

Delphinus albicans, O. Fabricius.

D. canadensis, Desm. (apud Gray).

Delphinapterus leucas, Gerard.

D. beluga et Beluga borealis, Lesson.

Catodon Sibbaldii, Fleming.

Catodon albicans, Lacepède.

Hab. Arctic regions; N. Atlantic and N. Pacific. A. Skull from Greenland. From the Royal Museum of Copenhagen (1840), J. A. S. VIII, 969.

Genus Monodon, Fabricius.

276. M. monoceros, L. (Scorseby, Arct. Reg. I, 486, III, p. 12, f. 1, 2).

Sys. M. unicornu, L.

M. narwhal, Blumenbach.

M. vulgaris, M. microcephalus et $M$. Andersonianus, et Narwhalus And., Lacepéde.

Narwhal.

HaB. Northern Ocean.

$A$. Tusk. Presented by Captain Lumsden, (1820), As. Res. XIV, App. III.

Genus Delphinus, L. (restricted).

277. D. eurynone, Gray (Zool. 'Erebus' and 'Terror,' $t$. 17 ; skull).

Hab. Indian Ocean ; Bay of Bengal.

$A$. Skull received from the Calcutta Medical College (1843). B. Another, from the Bay of Bengal. Presented by Captain Jethro Fairweather (1860).

278. D. obscurus, Gray (Zool. 'Erebus' and 'Terror,' $t$. 16 : skull). 
Syn. D. cruciger, Quoy and Gaymard, ? Voy. Uran. t. 12, f. $3,4$.

D. bivittatus, D'Orbigny, Voy. Am. Merid., Mam., t. 21.

D. albigena (?), Quoy and apud Gray. Gaymard.

D. superciliosus, Schlegel.

D. Fitzroyi, Waterhouse, Zool. Beagle, t. 10 (young).

HaB. S. Ocean, Cape of Good Hope.

$A$. Skull. Presented by ?

279. D. Frithir, Blyth, J. A. S. XXVIII, 492.

Has. S. Atlantic. (1847).

280. D. Perniger, Elliot, J. A. S. XVII, 250, XXVIII, 491.

HAB. Bay of Bengal.

$A$. Stuffed specimen. Presented by the Hon'ble Walter Elliot, Madras C. S. (1848).

Genus Lagenorhyncinus, Gray.

281. L. Leucopleurus (Zool. 'Erebus' and 'Terror,' t. 12 ; skull).

Srn. Delphinus leucopleurus, Rasch.

D. tursio apud Knox (Gray).

HAB. Northern Ocean.

$A$. Skeleton of a specimen killed in the fiörd of Christiania, June, 1848. Presented by the Royal University of Christiania (1844).

Genus Steno, Gray.

282. St. frontatus (Cuv. Oss. Foss. V.t. 20, f. 7, 8).

Syn. Delphinus frontatus, Cuvier.

D. Reinwardtii, Schlegel, apud Gray.

HAB. Indian Ocean; Bay of Bengal; Red Sea. $A$. Skull, from a specimen taken in the Red Sea. Presented by J. Owen, Esq. (1844). B. Another (one ramus of lower jar wanting). From the Bay of Bengal. Presented by Capt. Lewis (1846). 
283. Sr. atrendatus, Gray (Zool. 'Erebus' and ' Terror,' $t$. 28 ; skull).

HAB. S. Ocean (C. Horn) : Bay of Bengal, \&c. A. Skull (As. Res. XII, App. XXVI ?) B. Another from the Bay of Bengal. Capt. Jethro Fairweather (1859). $C$. Another, from W. of C. G. Hope. Presented by Major R. C. Tytler (1859), $D$. Lower jaw, "from the high seas." C. Hervey, Esq. (1841).

28:. ST. — ? J. A. S. XXVIII, 491.

HAB. ?

$A$. Left ramus of lower jaw, with deep symphisis and series of 43 teeth. Presented by ?

Genus Platanista, Antiq.

285. Pl. Indi, Blyth, J. A. S. XXVIII, 493.

HAB. Indus and its tributaries.

A. Skull (maxillary crests wanting). Presented by Sir A. Burnes (1840).

286. Pl. Gangetica (Ann. Mag. N. H. vol. IX, 1852, pl. V, VI, VII).

SrN. Delphinus gangeticus, Lebeck.

D. rostratus, Shaw.

D. Shavensis, Blainville.

Susu, H. ; Susuk, B.

HAB. Ganges and Bráhmaputra, with their tributaries.

$A$. Stufied female, 6 ft. long. Presented by M. Alfred Duvaucel (1822), As. Res. XV, App. XXXII. B. Stuffed female, $7 \mathrm{ft}$. long. Procured by the Curator (1843). C. Young female stuffed. Procured by the Curator (1849). D. E. Skulls of adults; the former toothless. Presented by Dr. Wallich, As. Res. XII, App. XXVI, Vide. J. A. S. XXVIII, 492.*

* I have heretofore been under the impression that the specimen presented by M. Duvaucel was of the male sex; but I find it otherwise, and certain discrepancies of proportion which I had suspected to indicate sexual diversity, may yet prove to be of specifical importance. I have never obtained a male of this animal. So far as can be judged from apparently a well stuffed specimen, that of $M$. Duvaucel is of more slender form, with a longer rostrum; unlike any that I have seen from the river Hugli. Entire length 6 feet to points of tailflukes, and $1 \mathrm{ft} .5 \frac{1}{2}$ inch. from gape to tip of rastrum; length of our Calcutta female

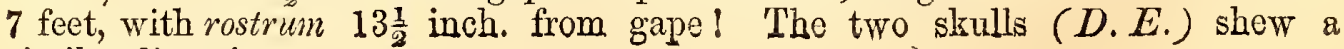
similar disparity. 
Sub-fam. CATODONTINAE.

Genus Catodon, Artedi.

287. C. Macrocephalus, Lacepéde (Branitt and Ratzburg,

Med. Zool., 12,f. 20, after Johnston).

Syn. Physeter trumpo, Bonnaterre.

I\%. catodon, O. Fabricius.

Ph. gibbus, Schreber.

Cachelot, or ' Sperm Whale.'

HAB. The Ocean: occasionally hunted at the entrance of the Bay of Bengal, within sight of Ceylon.*

$A$. Serics of five teeth. Society's old collection.

B. A pair of auditory cochlex, of unequal size; supposed to belong to at least this sub-family (J. A. S. XXVIII, 489).

Fam. BAL AENID ZE.

Genus Balanoptera (pars), Lacepéde.

288. B. IndicA, Blyth, J. A. S. XXVIII, 488.

Hab. Indian Ocean; Bay of Bengal; Arabian Sca; occasionally entering the Persian Gulf.

A. Two rami of lower jaw of an individual 84 feet in length; described $J$. A. S. XXVIII, 487 ; $B$. Left rarlius of the same, ibid.; $C$. Rib of ditto, ibid.; D. E. F. G. H. Series of nive vertebra, ilizd. From the Bay of Bengal. Presented by Major ' $\mathrm{l}$. P. Sparkes (1852). I. Head and portion of vertebral column of a smaller individual (now much injured by long exposure to all weathers); vide J. A. S. XXVIII, 488. Presented by J. Swinton, Esq. (1830). J. Pair of ear cochlea. Presented by ditto? $K$. Left ditto, probably that noticed in J. A. S. V, 374, as having been presented by the late J. Prinsep Esq.

Genus Balena, L.

289. B. Mysticetus (Gray, Zool. 'Erebus' and 'Terror,' 15,$47 ; t .1, f .4$, baleen).

* Species doubtful, however, as idcntical with that inhabiting the northern seas, to which the above names apply. 
SYN, B. græenlandica, L.

B. vulgaris, Brisson.

B. Rondoletii, Willoughby. $\}$ apud Gray.

B. physeter, Pallas. Arctic 'Right Whale.' J

HaB. Northern Ocean.

A. A flake of baleen. Presented by the Rev. Dr. McGowan (1860).

290. B. australis (?), Desmarest.

Syn. 'Le grand Balein du Cap,' Cuvier.

$A$. Series of three vertebræ. $B$. A pair of humeri. $C$. A pair of scapulæ. Described $(J . A$. $S$. XXVIII, 488-9). D. Pair of ear-cochlece. Ditto, provisionally assigned to the present species, Ditto, p. 489.

-(?) Phytophagoida.-(?) Diplodontia.*

Order (?) — Sub-order RODENTIA.

Family SCIURIDAE. Sub-family PTEROMYDINAE.

Genus Pteromys, Cuvier.

291. Pt. Petaurista, J. A. S. XXVIII, 276 (Pallas, Misc. 54, t. 6 ; Buffon, H. N. Supp. III, $t$. 21, VII, t. 67).

Syn. Sciurus petauristc (mas), Pallas

Ph. philippensis, Gray, apud Elliot.

Pl. oral, Tickell.

Oral, of the Coles (Tickell).

НАв. Central India; Malabar; Ceylon.

$A$. Adult, from Travancore. Presented by Lord Arthur Hay (1846). B. Young, from Midnapur jungles. Presented by P. Homfray, Esq. (1843). $C$. D. E. Skulls, one presented by Lt. Vicary (1837). $\quad F$. Skull from $B$.

292. PT. cineraceus, Blyth, J. A. S. XXVIII, 276. 
SYN. Ph. petaurista, var. cineraceus, Bl. J. A. S XVI, 865.

Shoo-byan, Arakan (Phayre).

HAB. Arakan; Pegu; Tenasserim Provinces.

$A$. Specimen from Arakan (very grey). Presented by Col. Phayre (1844). B. Another from Arakan (more rufescent, but with whitish tail). Presented by Col. Phayre (1844). C. Another from Tenasserim (colour unusually rufous, with concolorous tail). Presented by Rev. J. Barbe(1844). $D$. Another from Pegu. Presented by Col. Phayre (1845). $E$. Half-grown specimen, from valley of Sitang river, Tenasserim. Presented by Major Berdmore (1847). F. Small young, from Arakan. Presented by Col. Phayre (1844). G. skull.

293. Pт. Inornatus, Is. Geoffroy (Zoologie of Jacquemont's Voyage).

Syn. Ph. albiventer (?), Gray, nec Hardwicke, Ill. Ind. Zool.

HaB. N. W. Himalaya ; Kashmir?

$A$. Specimen purchased at Simla, and presented by Capt. Thomas (1845). B. Half-grown example, from Landour. Presented by Dr. L. C. Stewart (1854). C. Skull. Presented by Dr. L. C. Stewart.

293. Pr. magnificus, Hodgson, vide J. A. S. XVI, 866, XXVIII, 277.

$\left.\begin{array}{l}\text { Syn. St. chrysothryx, Hodgson. } \\ \text { Sciuropterus nobilis, Gray. }\end{array}\right\}$ Variety.

Hab. S. E. Himalaya; Asám.

$A$. Variety with hoary tips to fur, especially inhabiting the hills bordering on Asám and Sylhet. Specimen from Asám. Presented by Mr. Robertson (1844). B. Young. Similar, from Cherra Punji. J. W. Laidlay, Esq. (1847). C. Example from Cherra Punji. Presented by F. Skipwith, Esq. (1848), and linking $A$. and $B$. in coloring to the next variety. $D$. Specimen with pale median line on back, and no hoary tips to fur. From Dorjiling. Presented by Willis Earle, Esq. (1848), -being the $H$. nobilis, Gray, \&c. E. Another from Dorjiling. Presented by Dr. A. Campbell 
(184). Similar, but with pale dorsal streak much less developed. $F$. Another, purchased. The dorsal streak obsolete; but otherwise resembling $D$. and $E$.

295. Рт. Nitidus, Geoffroy, vide J. A. S. XXVIII, 277.

Srr. Sciurus petaurista (fœm.), Pallas.

Bielok or Bolok of the Sundause (Muller and Schlege?).

Hab. Malayan peninsula, Sumátra, Jáva, and Borneo.

$A$. Adult. $B$. Young. From Malacca. Presented by the Rev. F. Lindstedt (1845).*

Genus Sciuropterus, F. Cuvier.

296. Sc. Caniceps, Gray (J. A. S. XIII, 1, 68),

Syn. Pteromys senex, Hodgson.

Hab. Sikhim.

A. Specimen from Dorjiling. Presented by Mrs. Oakes (1842).

297. Sc. Fuscocapillus, Jerdon, nobis, J. A. S. XVI, 867, XXVIII, 286.

HAB. S. India.

A. B. Specimens (fragmentary), from S.Malabar. Presented by Rev. H. Baker, Jun. (1859).

298. Sc. fimbriatus, Gray, M. N. H. n. s. I, 84.

HAB. N. W. Himalaya.

A. Specimen obtained near Simla. Presented by L. C. Stewart, Esq. (1854). B. Another, Society's old collection.

299. Sc. villosus, Blyth, J. $A$ S. XVI, 866.

Srn. Pteromys sagitta apud Walker, Calc. J. N. H. III, 266.

Haв. S. E. Himalaya; Asám.

A.B. Specimens from N. Asám. Mr. F. Bonynage (1844). C. Another, from Sikhim. Presented by

Desid. P'T. Phildippensis (verus), Gray. Philippines.-Pt. elegans, S. Muller. Java.-Pt. griseoventer et P'r. melanotrs, Gray (if admissible.)-PT. PuncтAтus, Gray. Malayan peninsula.-P'т. Diskuri, 'I'em.-? 
300. Sc. fuscocapillus, Bl., Jerdon, J. A. S. XVI, 867 ; XXVIII, 278, 286.

Hab. S. Malabar.

$A$. B. Fragments of skins of old and young: presented by the Rev. H. Baker, Junior (1859), J. A. S. XXVIII, 286.

301. Sc. fimbriatus, Gray, P. Z. S. 1837, p. 68.

Syn. Pteromys Leachii (?), Gray, P. Z. S. 1836 , p. 88.

Haв. N. W. Himalaya.

$A$. Specimen from the Socicty's old collection. $B$. Another from near Landour. Presented by L. C. Stewart, Esq. (1855).

302. Sc. Alboniger, Hodgson, J. A. S. IV, 513, V, 231. Syn. Sc. Turnbullii, Gray.

Haв. S. E. Himalaya (Nipal, Sikhim, Butan).

$A$. B. Specimens from near Dorjiling. Presented by Mrs. Oakes (1842). C. Another. Presented by Mr. Grace (1855).

303. Sc. villosus, Bl., J. A. S. XVI, 866.

Srn. Sc. sagitta from Asám, apud Walker.

Hab. Sikhim, Butan, Asám hills.

A. B. Specimens from N. Asám. Presented by Mr. F. Bonynge (1845). C. Another, from near Dorjiling. Presented by Mr. Theobald (1852). D. Skeleton (right fore-limb wanting). Presented by W. T. Blanford, Esq. (1855).

304. Sc. Phayrei, Bl., J. A. S. XXVIII, 278.

SYN. Sc. sagitta of Burmá, J. A. S. XXIV, 187.

Hab. Pegu ; Tenasserim provinces.

A. B. C. D. Specimens presented by Major

Berdmore and Colonel Phayre (1855-7).

305. Sc. spadiceus, Bl., J. A. S. XVI, 867.

Kywet-shoo-byan, Arakan. 
Hab. Arakan.

A. B. C. Specimens presented by Colonel Phayre (1844-5).

306. Sc. volucella (F. Cuv., Mamm. Lith. I, t. 80).

Sxn. Sciurus volucella, Pallas.

Sc. acrobates, Schreber, t. 222.

Mus volans, $\mathrm{L}$.

Sciuropterus americanus, Desmarest.

Hab. N. America.

A. Skeleton, from N. Carolina. Presented by the Rev. F. Fitzgerald (1852).*

Sub-fam. SCIURIN $A$.

Genus Scrurus, L.

(A. The group of gigantic Squirrels. $\dagger$ )

307. Sc. Maximus (?) apud Blyth, $J$. A. S. XXVIII, 287.

Syn. Sc. maximus (?), Schreber, apud Horsfield, Ind. Mus. Catal.

HAв. S. Malabar.

$A$. Stuffed specimen. B. Flat skin. Presented by the Rev. H. Baker, Junior (1859): vide loc. cit. C. $D$. Stuffed specimens, presented by Mrs. Turnbull (1862).

308. Sc. (nec Sc. ElphinstoneI, Sykes), J. A. S. XXVIII, 287.

HAB. Central India (whence commonly brought alive to Calcutta, and apparently never varying).

* Desid. Sc. Layardi, Kelaart, nobis, J. A. S. XX, 165. Mountains of Ceylon.-Sc. BABerI (?), Bl., J. A. S. XVİ, 866. Trans-Himálayan.-Sc. Fuscocapillus, Jerdon, nobis, ut supra.-Sc. Horsfieldir, Waterhouse (Pteromys aurantiacus, Wagler). Malayan peninsula.-Sc. GENIBarbis, Horsfield.' Java, Malayan peninsula.-Sc. lepidus, Horsfield, apud Gray.-Sc. SAGrTta, (L.), vera Java-Skeleton of any large Pteromys.

$\dagger$ Sciurus maximus, Temminck. Peculiar to S. E. Asia and its archipelago, as far east as Borneo and Java ; or having nearly the same (though not quite so extensive a) range as restricted Pteromys. Like that genus, exhibiting permanent varieties of colouring, each peculiar to a certain range of distribution ; and in some instances the size is more or less reduced, e.g. Sc. Hrpoleucos and Sc. AlBIPES. It is difficult to conceive of the whole series as other than permanent varieties of one species ; and the same remark applies to the races of Prsiomys, and to at least some of those of Sciuropterus, as also to various named ScIURI. 
$A, B . C$. Specimens presented by Bábu Rajendra Mállika and others (1842-53). $D$. Skeleton.

309. Sc. BICOLOR, Sparrman (apud Horsfield, P. Z. S. 1839, p. 151; also apud Schinz, and Cantor, J. A. S. XV, 246).

SYN. Sc. affinis, Raffles.

Sc. aureiventris, Is Geoff Pale Malayan

Sc. giganteus, McLelland. $\{$ Himálayan

Sc. macrouroides, Hodgson. $\left\{\begin{array}{l}\text { race, with } \\ \text { tufted ears. }\end{array}\right.$

Chinkrà-whah, Malay; Leng-thet, Arakan.

$\mathrm{H}_{\text {AB.* }}$ Var. with densely clad ear-conch, as in preceding races: S. E. Himalaya; Asám; Sylhet? Munnipur? Var., with sub-nude ear-conch: $a$, with pale fur, Malayan peninsula, Sumatra: $b$, with dark upper-parts. Arakan, Tenasserim provinces, Malayan peninsula, Sumatra?

$A$. Stuffed specimen. B. Skin. Both not very dark. From Upper Asám (Sc. macrouroides). Presented by Captain Bonnevie (1848) and Captain E. F. Smyth (1859). C. Dark example, from Tenasserim. Presented by E. O'Reilly, Esq. (1849). D. Very brownish example, with some whitish hairs on tail; from Arakan (Ramri). Presented by Major Abbott (1844). E. Skin from Tenasserim, with broad pale transverse band on loins, forming a kind of cincture. $\dagger$ $\boldsymbol{F}$. Stuffed specimen, also from Tenasserim, with pale body, darker head, shoulders, and limbs, and blackish paws and tail. Presented by Colonel Jenkins (1845). G. H. Pale specimens (Sc. affinis, Raffles), from Malayan peninsula. Presented by Messrs. Frith and W. E. Lindstedt (1846), and Mr. Moxon (1847).

310. Sc. Hypoledcos, Horsfield.

* Vide J. A. S. XVI, 870.

$\dagger$ This proves to be a local race. Vide J. A. S. XXXI, 194. 
Syn. Sc. Leschenaultii, et Sc. alliceps, Desmarest. Sc. humeralis, Coulson (?).

Sc. Finlaysoni, Horsfield.

HAB. Java (apud S. Müller); Sumatra (apud Horsfield).

A. Specimen presented by Mrs. Major Turnbull (1857).

311. Sc. ephippium, L., S. Müller (Verhand., Mainmalia, $t$. 13).

Hab. Borneo (nec Java), apud S. Müller.

$A$. Specimen presented by the Batavian Society (1844), and described in J. A. S. XVI, 870-1.

312. Sc. Tennentit, Layard, J. A. S. XVIII, 600, XX, 165.

Hab. Highlands of Ceylon.

A. B. Stuffed specimens. Presented by Dr. E. F. Kelaart (1846).

313. Sc. Macrourús, Forster, nec Say, described in $J . A$. S. XVI, 869. (Pennant's Indian Zoology).

SrN. Sc. ceylonensis, Boddäert.

White-legged Squirrel, Pennant, Quadr. II, 407.

HAB. Lower hills of Ceylon (where said to be peculiar to the W. coast). Also S. Malabar, Nilgiris, and other districts of S. India.

$A$. Fine specimen. Presented by Dr. Templeton (1846). B. C. Pale and dark adults. Presented by E. L. Layard, Esq. (1848). D. Young, with terminal two-thirds of tail white. Presented by E. L. Layard, Esq. Also an imperfect skin of a young animal, as pale as Sc. BICOLOR (var. affinis, Raffles). $E$. Skin from the Nilgiris. Presented by, Captain K. Rollo (1845). F. Stuffed specimen. Presented by Dr. E. F. Kelaart (1852). , G. Skull.

314. Sc. Albipes, Blyth, J. A. S. XXVIII, 287. 
HAB. - ?

A. Stuffed specimen. From the Calcutta Medical College', in the collection attached to which the skeleton of the same individual is set up.*

(B. The group of medium-sized Squirrels with grizzled fur, proper to S. E. Asia and its archipelago. $\dagger$

Remark. The first two are of larger size, with much white on the sides.)

315. Sc. Rafflesir, Vigors and Horsfield, vide J. A. S. $\mathrm{XVI}, 871, \mathrm{XXIV}, 472$.

Syn. Sc. Prevostii, Desmarest.

Sc. rufoniger (?), Gray (from Malacca).

Tìpai Baláng, Malay (Cantor). Ann. $M$. N. H., X (1842), p. 263. Var.?

Hab. Malayan peninsula (nec India).

$A$. $B$. Specimens from Malacca, one presented by R. W. G. Frith, Esq., the other procured by exchange (1846).

316. Sc. Redimitus, Van der Boon, vide J. A. S. XXIV, 472.

SYN. Sc. rufogularis, Gray (half grown; from China. $\ddagger$

Sc. Rafflesï, Var., S. Müller.

Hab. Borneo. $\S$

$A$. Specimen presented by the Batavian Society (1844).

(The next four races-with probably others-are also very closely akin, but inhabit different localities, from which they are respectively true to the details of their coloring).

317. Sc. Ferrugineus, F. Cuvier (Mamm. Lithog. III, pl. 167 ).

* Desid. Sc. Elphinstonei ; Sykes, P.Z. S. 1831, p. 103. Hab. N. Malabar, chiefly the Bombay Presidency.

$\dagger$ Extraordinarily developed in the Indo-Chinese countries and Malayan peninsula, where the species or permanent races would seem to be almost endless, differing more or less in size and coloring: in India confined to the middle region of the S. E. Himalaya, and to the provinces N. E. of Lower Bengal.

$\ddagger$ Vide note by Dr. Cantor in J. A. S. XV, 248.

$\S$ Sumatra, also, has probably its corresponding race, if not other islands. 
Srn. Sc. Keraudrenii, Is. Geoffroy, vide $J . A . S$. XXIV, 474, XXXI, p.

HAB. Hilly regions of Arakan and Pegu.

$A$. B. Specimens presented by Col. Phayre (1845).

318. Sc. erythreus, Pallas, vide J. A. S. XXIV, 473. SxN. Sc. hippurus, var., McClelland and Horsfield, P. Z. S. 1849 , p. 152.

HAB. Khásya hills, and neighbouring mountains of Lower Asàm.

$A$. B. Specimens from Cherra Punji. Presented by Fulwar Skipwith, Esq., B. C. S. (1851). C. D. Young, from Asám. Presented by Col. Jenkins (1847).

319. Sc. HIPPURIS, Is. Geoffroy.

SrN. Sc. rufogaster, Gray.

Hab. Malayan Peninsula, Sumatra, Java, Borneo (?).

A. B. Specimens from Malacca. Presented by R. W. G. Frith, Esq. (1844).

320. Sc. erythrogaster, Blyth, J. A. S. XI, 970, XXIV, 173.

$\mathrm{H}_{\mathrm{AB}}$. Munipur Hills, and those E. and S. of Upper Asám.

$A$. Specimen from Munipur. Presented by Col. C. S. Guthrie, B. E. (1842).

321. Sc. HYperythrus, Blyth, J. A. S. XXIV, 474.

Srn. Sc. erythreus, var. $A$ (?), Gray's Br. Mus. Catal.

Нав. Tenasserim provinces; hills between Pegu and Martaban (?)

$A$. Specimen from Moulmein (?). Presented by Major Berdmore (1852).

322. Sc. Castaneoventris, Gray.

Srn. Sc. griseopectus, Bl., J. A. S. XVI, 873.

HAB. China. 
$A$. Specimen presented (recent) by Bábu Rajendra Mállika (1847). B. Another, from Amoy. Presented by W. Swinhoe, Esq. (1860).

323. Sc. CIRYsonotus, Blyth, J. A. S. XV, 873, XXIV, 474.

HAB. Tenasserim provinces; common southward. A. B. C. D. Specimens presented by the Rev. J. Barbe and E. O'Reilly, Esq. $(1846-50) . \quad E$. Specimen with uniformlycolored upper-parts, from Mergui (barely separable from next). Presented by Major Berdmore (1854). $F$. Skull.

324. Sc. concolor, Blyth, J. A. S. XXIV, 474.

Syn. Sc. modestus (?), A. Müller, apud Bl., J. A. S. XX, 166.

НАв. Vicinity of Malacca. (1847).

A. Specimen presented by Capt. Moxon

325. Sc. Pygerythrus, Is. Geoff. Zool. do Voy. de M. Belanger, vide J. A. S. XXIV, 475.

HaB. Valley of the Irawádi (Lower Pegu).

A. B. C. D. Specimens presented by Dr. Fayrer and by Major Berdmore (1847 and 1857).

326. Sc. assamensis, McClelland, Gray, vide J. A. S. XXIV, 475.

Syn. Sc. Blythii, Tytler, Ann. Mag. N. H. September 1854, p. 72.

Haв. Valley of Bráhmaputra; E. Bengal; Tippera, Chittagong, Arakan (a very abundant race).

A. B. C. D. Specimens from Arakan. Presented by Col. Phayre (1844). C. D. ditto, from Asám. Presented by Col. Jenkins (1846). $E$. R. Young, from Káshya hills. Presented by F. Skipwith, Esq. (1848). 
327. Sc. Lokriah, Hodgson (nec apud Gray, Br. Mus. Catal.)

Syn. Sc. subfaviventris, McClelland, vide J.A. S. XXIV, 475.

Haв. Nepâl, Sikhim, Asám, Khásya hills, and those of Arakan : a mountain race.

A. B. C. Specimens from Nepâl. Presented by Mrs. Oakes and others (1843-6). $D$. Another (half grown), from Arakan. Presented by Col. Phayre (1846).

328. Sc. Lokroides, Fiodgson. Sc. lokriah, apud Gray, (Br. Mus. Catal., vide J. A. S. XXIV, 475).

Hab. S. E. Himalaya ; (Nepâl, Sikhim, Butan tárai.)

A. B. C. Specimens from Dorjiling (with thighs deeply tinged with ferruginous). Presented by the Curator (1851). D. E. F. Specimens, also from Dorjiling, without the rufous tinge on the thighs. Presented by C. J. Bonnevie, Esq. (1848).

329. Sc. TEnuIs, Horsfield, vide J. A. S. XXIV, 476.

HAB. Malayan Peninsula, Java, Borneo, Sumatra.

$A$. Specimen from Java. Presented by the Batavian Society (1844).

330. Sc. Phayrei, Blyth, J. A. S. XXIV, 476. XXVIII, 275.

Srn. Sc. pygerythrus, var.? J. A. S. XVII, 345. $\mathrm{H}_{\mathrm{AB}}$. Common in Martaban province.

$A$. B. C. Specimens shot by the Curator in Upper and Lower Martaban (1861). $D$. Skull.

331. Sc. Blanfordir, Blyth, J. A. S. XXXI.

Hab. Vicinity of Ava, and Shan Hills. A. Specimen presented by W. T. Blanford, Esq. (1862).

332. Sc. vittatus, Raffles, vide $J$. A. S. XXIV, 476 ; F. Cuv. Mamm. Lith. II, pl, 68 . 
Syn. Sc bivittatus, Desmarest.

Sc. flavimanus, Is. Geoffroy.

Macroxus toupai, Lesson.

H九в. Malayan peninsula, Sumátra, Borneo.

A. B. C. Specimens presented by Mr. E.

Lindstedt and Mr. Moxon (1849). C, $\alpha$. Skull.

333. Sc. Nigrovitwatus, Horsfield. Vide J. $A$. S. XXIV, 476.

Syn. Sc. griseoventer, Is. Geoffroy. VideJ.A. S. XXIV, 476.

Hab. Malayan peninsula, Sumátra, Java, Borneo. A. B. C. Specimens. Presented by Mr. G. Moxon and the Rev. F. Lindstedt (1849).

334. Sc. atrodorsalis, Gray. Vide J. A. S. XXIV, 477, XXVIII, 276.

Hab. Common on the hills about Moulmein ; replaced on the opposite of the Salween by No. 320. Certainly not Butan, as stated by Gray.

A. B. C.D.E.F. Fine series. Presented by W. S. Atkinson, Esq., Major Tickell, and others.

(C. The American group of Squirrels.)

335. Sc. Levcotis, Gappar.

SrN. Sc. cinereus, Harlan.

Sc. carolinensis, Godman.

Haв. N. America (southward).

A. Specimen from N. Carolina. Presented by the Rev. F. Fitzgerald (1852).

(D. The group of Squirrels inhabiting northern regions.)

336. Sc. Hudsonius, Pallas (F. Cuv., Mamm. Lithog., III, pl. 72).

SyN. Sc. rubrolineatus, Desmarest. Sc. vulgaris, var. E., Erxleben.

Ha B. N. America (northward).

A. Specimen from Mr. Bartlett (1842). 
337. Sc. EÙropeus, L. (F. Cuv. Mamm. Lithog., II, pl. 63). SYN. Sc. varius, Pallas.

Sc. alpinus, F. Cuv.

Sc. vulgaris niger, Schreber.

Sc. vulgaris cinereus, Frische.

Mustela calotes, Hodgson, Calc. Journ. N. H. II, 221, pl. IX (apud Gray.)

H^в. Europe; N. Asia.

A. B. C. Specimens from England. Presented by the Cornish Institution, Messrs. Bartlett, and Davison (1842-6). D. E. Skulls. Presented by Mr. Bartlett.

$(E$. The small striped Squirrels of S. Asia; known as 'Palmists.')

338. Sc. Berdmorei, Blyth, $J$. A. S. XVIII, 603 ; XXVIII, 418 ; XXXI.

Haв. Martaban, Mergui, \&c. (Tenasserim Ground Squirrel). (1861).

$A$. B. Specimens obtained by the Curator

339. Sc. Palmarum, L. (Buffon, $H$. N., X, t. 26).

Srn. Sc. penicillatus, Leach, Zool. Misc. 6, t.*

$\mathrm{H}_{\mathrm{AB}}$. India generally; frequenting cultivated tracts and avoiding jungles. Does not. appear to inhabit Ceylon, nor the eastern coast of the Bay of Bengal. The only Squirrel about Calcutta, and towns generally that contain gardens; also throughout the plains of Hindustan and the Punjab.

$A$. B. Specimens from the Society's premises (1842).

340. Sc. tristriatus, Waterhouse, vide J. $A . \quad S$. XVIII, 874.

Syn. Vars.-Sc. Brodiei et Sc. Kelaarti, Layard, J. A. S. ,XVI 602, et XX, 166 : both from Ceylon.

* $N$. B. Dr. J. E. Gray refers this to the next species ; but the locality where the specimen was obtained (Madras) at once decides the question. Besides, of very many continental examples of $S c$, tristriatus, I never yet saw one with the terminal pencil-tuft to its tuil. Vide J. A.S.XVI, 874. 
Ha . Jungly parts of India, and lower forest-clad hills, avoiding the plains; also Ceylon, where exhibiting at least three marked local varieties.

$A$. B. Specimens from the Midnapore jungles, procured by the Curator. $C . D . E$. Similar examples from Ceylon (where "the common low-country Squirrel" apud Layard). F. G. H. Rufous-capped variety (Sc. Brodiei), one example having the dorsal stripes unusually white (the common Striped Squirrel of the W. coast). I. J. Dull-colored variety (Se. Kelaarti), with penicillated tail (S. E. and E. ? coast of "Ceylon). Presented by Dr. Templeton, E. L. Layard, Esq., and Dr. Kelaart (1845-50).

341. Sc. Layardi, Blyth, J. A. S. XVIII, 600.

$\mathrm{H}_{\mathrm{AB}}$, Mountain region of Ceylon.

$A$. Specimen presented by E. L. Layard, Esq. (1849).

342. Sc. sublineatus, Waterhouse, vide J. A. S. XVI, 875.

Srn. Sc. Delesserti, Guérin.

HAB. Mountains of S. India and of Ceylon.

$A$. Nilgiri specimen. Presented by Dr. Jerdon (1844). B. Another, from S. Malabar. Presented by Rev. H. Baker, Junior (1859). C. Another, from Ceylon. Dr. Kelaart (1851).

343. Sc. Barbei, Blyth, J. A. S. XVI, 875, XVIII, 603.

HaB. Tenasserim Provinces; Siam.

A. B. C. Specimens presented by the Rev. J. Barbe and Major Berdmore $(1843-6)$. $D$. Another, entire in spirit. Presented by Col. Phayre (1853).

344. Sc. Maclellandir, Horsfield, vide J. A. S. XVI, 875.

Syn. Sc. Pembertonii, Blyth, J. A. S. XI, 887. 
Haв. Sikhim, Butan.

A. B. C. D. Specimens from Dorjiling. Presented by Mrs. Oakes, Mr. Grace, and others (1843-5). E. Example in spirit. Presented by W. T. Blanford, Esq. (1858).

Genus Rhinosciurus, Gray.

345. RH. Tupaoides, Gray, vide J. A. S. XXIV, 418.

Syn. Sc. laticaudatus, (?), S. Müller.

Hab. Malayan peninsula; Sumátra? Borneo?

$A$. Specimen presented by Mr. Moxon (1851).

Genus Xerus, Ehrenberg.

346. X. setosus; Sciurus setosus, Forster (Rüppell, Atlas, $t . \quad$ ).

Syn. Sc. Levaillantii, Kuhl.

Sc. leuco-umbrinus, Rüppell.

Sc. albovittatus, var., Desm.?

Sc. namaquensis, Lichtenstein.

Sc. erythropus, Geoffroy.

Sc. capensis, 'Thunberg.

HAв. E. W. and S. Africa.

A. Specimen from S. Africa. Presented by E. L. Layard, Esq. (1859).*

347. X. RUtilans; Sciurus rutilans, Cretsch.

Sxn. $X$. brachyotus, Hemprich and Ehrenberg, Symb. Ph., t.

A. Specimen from Somâli-land. Presented by Capt. Speke (1855), J. A. S. XXIV, 93.

\section{Sub-fam. ARCTOMYDINA.}

Genus Arctomys, Schreber.

348. A. вовас, Schreber (Pallas, Glires, t. 8).

Syn. Mus arctomys, Pallas.

A. fulvus, Eversmann.

* Another specimen was presented by Dr. Rüppell, J. A. S. XXIV, 22 ; but it could not he set up: and the same remark applies to the example of Sciuros multiculor, Rüppell (Sc, cepate, A. Smith), noticed loc. cit. 
A. 'tibetanus et himalayamus, etiam herrachalanus (?), Hodgson.*

A. caudatus, Jacquemont.

Hab. High mountains of Asia, chiefly transHimalayan.

$A$. Stuffed example from Tibet: and $B$. Young (both with mutilated tail). Presented by B. H. Hodgson, Esq. (1845). $C$. Another, brought alive from the Sikhim Himalaya, and presented by the late G. A. Bushby, Esq., B. C. S. (1848). $C$, $a$. Skeleton. $\dagger D$. Large skull, presented by Lieut. Brownlow. E. Another skull from the Burnes' collection. $F$. Imperfect skull of young.

Fam. MYOXID $\mathbb{E}$, Waterhouse.

Genus Platacanthomys, Blyth, J. A. S. XXVIII, 288. 349. Pl. Lasiurus, Blyth, loc. cit. p. 289.

Hab. S. Malabar.

A. B. C. D. Specimens presented by the Rev. H. Baker (1859).

Genus Mroxus, Schreber.

350. M. GLIS ; Sciurus glis, L. (Buffon, H. N. VIII ; F. Cuv. Mamm. Lith. II, pl. 69).

Syn. Mus dryas, Schreber.

Hab. Continental Europe.

A. Specimen from France. Presented by Mons A. Malherbe (1854, J. A. S. XXIII, 212).

351. M. avellenarius; Mus av., L. (Buffon, $H . N$. VIII, 193, t. 26 ; F. Cuv., Mamm. Lith. II, pl. $71)$.

* The main distinction between Mr. Hodgson's $A$. tibetanus and his $A$. hemachalamus, hodiè, consists in the former bcing nearly twice as large as the other, and having a proportionally much shorter tail. I cannot satisfactorily discriminate two species in the Society's skins and skulls.-Vide J.A. S. XII, 409.

$\dagger$ This animal lived for many months in the Society's compound, and seemed to be indifferent to the hottest sun-shine, in which he habitually basked, lying on his back; and in this position he was at last found dead, apparently from repletion. 
Haв. Europe ; Britain.

$A$. B. C. Stuffed specimens. D. $E$. Skulls, sent by Mr. Bartlett (1843).

Yam. DIPODID A (Gerboida, Waterhouse, M. N. H., n. s., III, 186).

Genus Dipus, L:

251. D. Mauritanicus, Malherbe.

Hab. Algiers (Oran).

A. Specimen presented by M. A. Malherbe, J. A. S. XVIII, 80.

Genus Alactaga, F. Cuvier.

252. A. BACTRIANA, nobis.

Syn. A. acontium apud nos, J. A. S. XV, 137.

A. indica, Gray, Ann. M. N. H., X (1842), 262.*

'Desert Rat' of Arthur Conolly, Overland Journey to India, I, 54.

Hab. Afghánistân.

$A$. Specimen from the Society's old collection. $B$. Skull (minus lower jaw) of another individual.

Fam. MURID必.

- Sub-fam. MURINA.

Genus Gerbillus, F. Cuv.

253. G. Indicus, Desmarest (Lin. Tr. VIII, 279, t. 7).

Syn. Dipus indicus, Hardwicke $(l, c$.$) .$

Gerbillus indicus et $G$. Cuvieri, Waterhouse, P. Z. S. 1838, p. 56.

Mus jencus, B. Ham., Icon. Ined.

Meriones apicalis, Kuhl, Beitr. 70 ? (apud Gray).

'Desert Rat' of Elphinstone, ' Cabûl' (vide Introduction).

Hab. Plains of India; Ceylon; Afghánistân.

* I decline to adopt the name indica for a species that there is no reason to suppose inhabits any part of India. 
A. B. C. D. E. F. Specimens of various ages, procured by the Curator in the Midnapur jungles. $G$. $H$. Specimens in spirit, and I. Skeleton, from Berhampore, presented by Mr. Theobald. I. Stuffed example from Midnapur, Dr. Young (1848). J. K. Ditto, from S. India; W. Elliot, Esq. (1843). L. $M$. Ditto, from Ceylon; E. L. Layard, Esq. (1858).*

254.' G. Afer, Gray, Sp. Zool., II, 10 (A. Smith, Ill. Afr. Zool., t. 35).

Syn. Mus sericeus, Temminck.

Meriones sericeus, Licht. ? (apud Gray).

G. africanus, F. Cuvier.

Meriones Schlegelii, Smuts.

HAB. S. Africa.

$A$. $B$. Specimens presented by E. L. Layard, Esq., J. A. S. XXIX, 99.

Genus Psammomys, Rüppell.

255. Ps. obesus, Rüppell (Atlas, t. 22, 23).

Syn. Dipus pyramidum, Geoff., F. Cuv., Sc. Nat. XVIII, 463 ? (apud Gray), Dict.

Haв. Egypt.

A. Specimen presented by Dr. Rüppell, J. A. S. XXIV, 252.

Genus Hapalotis, Lichtenstein.

256. H. apicalis, Gray, P. Z. S. 1851, p. 126.

Haв. S. Australia.

$A$. B. Specimens presented by the Melbourne Institution (1861).

257. H. MITCHELLII,

Syn. Dipus Mitchellii, Ogilby, Tr. Lin.' Soc. XVIII, 129.

* I cannot perceive the slightest difference in specimens from all the localities noted. Perhaps, on the average, the southern specimens may be a little longer in the tarsus ; but the dividing line is most assuredly untraceable. Desid. G. ERÝthrourus, Gray, Ann. M. N. H., X (1842), 266, J. A. S. XV, 139. Hab. Afghánistân. 
Hab. S. Australia.

$A$. B. Specimens presented by the Melbourne Institution (1861).

Genus Hapalomys, Blyth, J. A. S. XXVIII, 411.

258. H. LONGICAUdatus, Bl., $l . c$.

НАв. Upper Martaban (valley of the Sitang or neighbouring hills).

A. Male, stuffed. B. C. Female and young in spirit. A. a. Skull. Presented by Major Berdmore (1859).

Genus Mus, L.

259. M. Bandicota, Bechstein (Lin. Tr. VIII, t. 18).

Syn. $\mathbb{M}$. giganteus, Hard̄wicke, $l_{\text {. }} c$.

M. malabaricus, Shaw.

M. ikria, B. H., M. S.

II. perchal, Shaw (from Buffon, H. N.; Supp., VIII, t. 69, apud Gray).

H. nemorivagus, Hodgson, J. A. S. V, 234, Ann. M. N. H. XV (1845), p. 266.*

Hab. India generally; Ceylon; Malayan peninsula and archipelago.

$A$. B. Adults; and C. Young: from Ceylon. Presented by Dr. Kelaart (1855).

260. M. (Nesokia, Gray,) Indicus, Geoffroy (Hardwicke, Ill. Ind. Zool., $t$. ).

Syn. Arvicola indica, Gray and Hardwicke.

Mus. kok (!), Gray.

M. ( Neotoma) providens, Elliot.

M. Huttoni, Bl. (?), J. A. S. XV; 139, which is Nesokia Griffithii, Horsfield, Ind, Mus. Catal., Mamm., p. 145.

MI. rattoides, Hodgson (apud Gray). $\dagger$

* According to Dr. Horsfield, M. nemorivagus is about one-third smaller than M. Bandicota. It inhabits the higher regions of Nipâl. (Ind. Mus. Catal., Mamm., p. 141). Our Cinghalese specimens accord in dimensions with $\mathrm{Mr}$. Hodgson's measurements, as also the Dimensions of Bengal individuals, as given by Buchanan Hamilton, $\boldsymbol{M} S$.

$\dagger$ At least Dr. Gray refers rattoides to INDicus, Desm., but this INDICUs, apud Gray, would appear not to be the Nesokia! Dr. Horsfield recognizes apart Nesokia Hardwickii, N. kok, and N. Griffithii, Ind. Mus. Catal., Mamm., p. 145. His Hardwickii is probably the adult, of which kok is the young! 
M. pyctoris (?), Hodgson.
M. dubius, Kelaart.

HAB. India generally and Ceylon; Afghánistân (?). A. B. C. D. Specimens from the Midnapur district. Procured by the Curator (1845). D. E. F. Ditto from near Calcutta (1843). G. H. Ditto from S. India; W. Elliot, Esq. (1842). I. J. Two flat skins from S. Malabar; Rev. H. Baker, Jun. (1855-59), J. A. S. . XXVIII, 290-1. $K$. Stuffed examples from Ceylon, Dr. Kelaart (1855). Specimens in spirit. Presented by the Curator.

261. M. Decumanus, Pallas (Glires, p. 90 ; Buffon, $N$. $H_{\text {。 }}$ VIII, $t .27)$.

Syn. $M$. norvegicus, Brisson.

M. brunneus, Hodgson, apud Gray, Ann. $M$. N. H. XV (1845), 226 ; Horsf. Catal., p. 142.

M. decumanoides, Hodgson (nec Temminck).

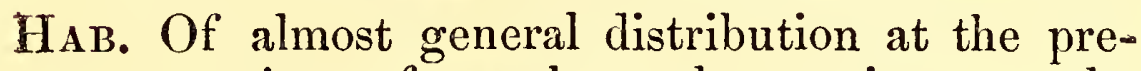
sent time, from the polar regions to the equator; in India chiefly observed about the ports. On the Burmese coast I observed them numerously at Akyab, but not elsewhere; though both this and M. RA'Trus are common to all ports frequented by foreign shipping. According to Fischer, this animal was introduced into Europe about the year 1731 (Synopsis Mammalium): but I doubt the current statement of its indigenous origin in Persia, \&c. Captain T. Hutton, in 1846, states that 'house Rats' are unknown in Kandahar! J. A. S. XV, 140.

A. B. C. D. Specimens from Calcutta. $E$. From England. Mr. Bartlett (1843). $F$. From China. Mr. Swinhoe (1861). $G$. Skeleton. H. Example, half-grown, with distorted teeth. Mr. Morgan (1862). I. Skeleton of adúlt.

262. M. hateus, L. (Buffon, $H$. N. VII, $t .36$; Schreber, t. 179). 
Syn. (?) M. rattoides, Hodgson, Ann. M. N. $H$. XV (1845), p. 267; referred by Dr. Gray to $M$. indicus, apud Gray.

$\mathrm{H}_{\mathrm{A}}$ B. Almost generally diffused at the present time; being the species which appears to have destroyed the small indigenous Rat, of frugivorous habits, indicated as a former inhabitant of New Zealand. In Calcutta, chiefly met with about the shipping.

$A$. B. Specimens obtained from a vessel in the port of Calcutta. Captain Godfrey (1846). C. $D . E$. Others from Fran:e. M. Malherbe (1849), J. A. S. XVIII, 80.

263. M. andamanensis, Blyth, J. A. S. XXIX, 103.

HAB. Andamán Islands; Barren-island volcano (?), J. A. S. XXXI,

$A$. B. Specimens presented by Capt. Hodge (1860).

264. M. robustulus, Blyth, J. A. S. XXVIII, 294.

Syn. M. Aluvescens, var., nobis, passim.

M. Berdmorei (?), nobis, J. A. S. XX, 173.

Hab. Valley of the Sitang River, Lower Pegu, and Martaban. Common house Rat of Rangoon and Moulmein. Also Mergui.

$A$. B. Adult and young in spirit; Schwe Gyen. Major Berdmore (1859). C. D. E. F. Stuffed specimens, and G. H. I. Examples in spirit, also from Major Berdmore. $J$. Flat skin, described as M. Berdmorei. $K$. Calcutta specimen, considered as a brown variety of M. RATTUS in $J$. A. S. XVII (1840), part II, p. 559.

265. M. nemoralis, Blyth, J. A. S. XX, 168.

Hab. Bengal ; Ceylon.

$A$. Adult. B. Young. Presented by Dr. Kelaart (1851). B. Example two-thirds grown. $C$. Young; and $D$. Young in spirit, from vicinity of Calcutta (1841-53).*

* It would really seem that this species interbreeds with M. FLAvescens and perhaps other kindred races ; as stated of M. DEcumarus, M. RatTus, and M. alexandrinus, in the Natural History Review, 
266. M. Cinnamoneus, Blyth, J. A. S. XVIII, 294.

Hab. Lower Pegu and Martaban.

$A$. Adult stuffed: and $B$. Skin in spirit. Presented by Major Berdmore (1859).*

267. M. Rufescens, Gray.

Srn. M. Alavescens et M. rufus, Elliot.

M. arboreus apud Horsfield, Ind. IIns. Catal., vide J. A. S. XX, 168.

M. Randianus, M. montanus, et M. ketragonurus, Kelaart, referred to in J. A. S. XX, 185.

M. caudatior (?), Hodgson, apud Gray.

НА в. India generally.

A. B. C. D. E. F. Stuffed specimens, old and young, from Calcutta and its vicinity. $G$. Ditto in spirit. H. Albinoid specimen, presented by J. Payter, Esq. (1853), J. A. $S$. XXII, 416. I. Remarkably colored variety from Society's compound (1844). $J$. Specimen sent (as was also a half-grown M. NEMORALIS) as the 'House Rat' of 'Trincomali, by Dr. Kelaart (1855). J. K. $L$. Examples in spirit; and $M$. Stuffed specimen, half-grown, from Newera Elia (sent as $M$. montanus et $M$. kandianus, Kelaart): Dr. Kelaart (1851.) N. Concolorous example from Malacca (M. setifer apud nos, passim, apparently distinct). $\dagger$ J. A. S. XXI, 433. $\begin{array}{llllll}X X I I, & 412 & (1852-3) . & U & V & V\end{array} \quad W$. Nearly similar variety, but with softer fur, Dorjiling. Major Sherwill (1858). $Y$. $Z$. Nearly similar variety ( $M$. niviventer (?), Hodgson). Landour, L. C. Stewart, Esq., (1855). Vide, however J. A. S. XXVIII, note to p. $295 . \ddagger$

* This is one of the best-defined speeies of the present sub-group.

+ According to Dr. Horsfield-“ "Allied to Mus Bandicota; but clearly distinct as a species." (Ind. Mus. Catal., Mamm., p. 142). Perhaps true M. SETIFER, Horsficld.

$\ddagger$ These white-bellied Rats and their immediate affines require far more extensive investigation and comparison of specimens from different regions than they have received hitherto. 
268. M. Nitrdus, Hodgson, Ann. M. N. H. XV (1845), p. 267.

HAB. Nipâl ; Sikhim.

A. B. C. D. E. F. G. Specimens from Dorjiling. Presented by Major Sherwill and Dr. Jerdon.

269. M. GouldiI, Waterhouse (Zool. 'Beagle', t. 25). Syn. M. lutreola, Gray, App. Gray's Trav., 409.

Haв: Australia.

$A$. Specimen received from the Sydney Institution (1846).

270. M. concolor, Blyth, J. A. S. XXVIII, 295 (the

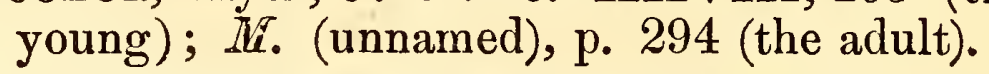

HAB. Upper and Lower Burmá; Malayan peninsula.

A. B. C. D. Specimens in spirit, from Upper Pegu and Martaban. Major Berdmore and W. T. Blanford, Esq. (1859-62). $E$. Stuffed specimen from Malacca. R. W. G. Frith, Esq. (1846). The last perhaps distinct.

271. M. infralinfatus, W. Elliot, $M$. $S$.

Syn.? M. Ellioti, Gray, Br. Mus. Catal, (undescribed).

HAB. S. India.

A. Specimen presented by W. Elliot, Esq., Madras C. S. (1841).

272. M. Peguensis, Blyth, J. A. S. XXVIII, 295.

Hab. Valley of the Sitang; Burmá.

$A$. Specimen stuffed. $B$. Another in spirit. Presented by Major Berdinore (1859).*

273. M. Sylvaticus, L." (Buffon, $H$. N. VII, $t .43$ ).

* This approximates the next, but has a still longer and more penicillated tail. 
Haв. Europe.

(N.B. There are two distinct races of this animal, one about twice the cubic size of the other. In England, I was informed of a much larger race than that of $\mathrm{S}$. Britain, existing in Aberdeenshire.

A. Larger race, inhabiting France, Switzerland, Norway? N. Britain?

$A$. Specimen from France, and $B$. Do. from Switzerland. Presented by Mons. A. Malherbe (1842), J. A. S. XXVIII, 80.

$B$. Smaller race, common in England (Bell's Br. Quadr., p. ).

C. D. E. F. G. Specimens from England: Presented by Mr. Bartlett and Mr. Davison (1843).

275. M. minutus, Pallas (Glires, t. 24, b. ; Bell's Br. Quadr., p. ).

Syn. M. messorius, Shaw.

M. soricinus, M. parvulus, et $M$. pendulinus, Herm., Schr. t. 183, b.

M. avenarius, Wolf.

II. campestris, F. Cuv.

M. pratensis, Ockskay (apud Gray).

Type of Micromys, Selys.

Ha b. Europe; N. Asia.

$A$. Specimen in spirit, from England. Presented by H. E. Strickland, Esq. (1844).

276. M.

HaB. Australia.

$$
\text { ? (J.A. S. XXXI, ). }
$$

$A$. B. Specimens presented by the Melbourne Institution (1862).

277. M. ? (J.A. S. XXXI, ).

Hab. Australia.

Specimen presented by the Melbourne Institution (1862). 
278. M. musculus, L. (Buffon, $H$. $N$., VII, $t$. 39, Supp. III, $t .30$; Bell's Br. Quadr., p. ).

Sxn. M. islandicus, Thienem. Reise, t. 8 (apud Gray).

M. adelaidensis, Gray, App. Grey's Travels, p. 410.

HAB. Europe ; and supposed to be cosmopolite; but I have never seen an Indian specimen.

$A$. Stuffed specimen from England, Mr. Kirtland (1845). B. C. Ditto, from N. Carolina. Rev. F. Fitzgerald (1852), J. A. S. XXI, 343.

279. M. Homourus, Hodgson, ${ }^{*}$ Ann. M. N. H., XV, (1845), p. 268.

$\mathrm{H}_{\mathrm{AB}}$. Entire range of the Sub-himálayan region, apparently. Common house Mouse of the hill stations.

$A$. Specimen in spirit, from top of $\mathrm{Pir}$ Pánjal Pass. W. Theobald, Esq., J. A. S. XXII, 583 (1853). B. Ditto. C. Stuffed example. From Dorjiling. Major W. S. Sherwill (1859), J. A. S.

280. M. urbanus, Hodgson, Ann. M. N. H., XV, (1845), p. 269.

Syn. M. musculus apud W. Elliot, MIadr. Jour. L. Sc. X, 214; and generally of India, auctorum; Kelaart, $J$. A. S. XX, 185, $\mathrm{XXI}, 351$ (vide $J$. A. S. $\mathrm{XX}, 172$, XXVIII, 296).

$M$. dubius, Hodgson (young ?).

M. Manei, Gray (undescribed).

HAB. The common house Mouse of the plains of India ; Ceylon; Andamán Islands (Port Blair).

A. B. C. D. Stuffed specimens. $E$. $\boldsymbol{F}$. $G$. $H$. Examples in spirit, Calcutta. $E$. Ditto, Port Blair, Andamán Islands, Captain Hodge (1860). $F$. Stuffed specimen, and G. H. I. Examples in spirit. From Ceylon. Dr. Kelaart (1852).

(* See Kelaart, vide J. A. S. XX, 1852.) 
281. M. Nitidulus, Blyth, J. A. S. XXVIII, 294.

Hab. Valley of the Sitáng river, Burmá.

A. B. C. Specimens in spirit. Presented by Major Berdmore (1859).

282. M. Gerbillinus, Blyth, J. A. S. XXII, 410.

Syn. M. Theobaldi, Blyth, J.A. S. XXII, 583. M. bactrianus (?), Blyth, J. A. S. XV, 140.

Hab. Alpine Punjáb (Pind Dádun Khán). Afghánistân (common house Mouse of Kandahar)?

A. Stuffed specimen. B. C. D. Examples in spirit. From Pind Dádun Khán. Wm. Theobald, Esq. (1853).

283. M. Folvidiventris, Blyth, J. A. S. XXI, 351. $\mathrm{H}_{\mathrm{AB}}$. Ceylon (Trincomali).

$A$. Stuffed specimen. Presented by Dr. Kelaart (1852). B. Anotlier, in bad condition.

284. M. Cervicolor, Hodgson, Ann. M. N. H., XV, (1845), p. 268.

Sxn. MI. albidiventris, Blyth, J. A. S. XXII, 351.

Hab. Nipâl ; Lower Bengal; S. Malabar (?)

$A$. B. C. Specimens in spirit. D. E. Ditto, stuffed. Vicinity of Calcutta (1852). $\boldsymbol{F}$. Stuffed example from S. Malabar, apparently referable to this species. Rev. J。 Baker, Jun. (1859), J. A. S. XXI, 112.

285. M. cunicularis, Blyth, J. A. S. XXIV, 721.

Hab. Khásya Hills.

A. B. C. Specimens in spirit, from Cherra Punji. Fulwar Skipwith, Esq. (1855).

286. M. Terricolor, Blyth, J. A. S. XX, 172.

Haв. Lower Bengal; S. India. (Common field and garden Mouse of Bengal.)

A. B. C. D. Stuffed specimens, from Mienapur jungles. $E$. $\boldsymbol{F}$. Ditto, from vicinity of Calcutta. G. H. Examples; in spirit, 
from neighborhood of Calcutta. I. Skin from S. India, sent together with $M$. LEPIDUS, from which it was not distinguished by the donor, W. Elliot, Esq. (1843).*

287. M. ERythrotis, Blyth, J. A. S. XXIV, 721. Hab. Khásya Hills.

A. Specimen from Cherra Punji. Presented by Fulwar Skipwith, Esq., B. C. S. (1855).

288. M. Pumilus, Sparrman. $†$

HAB. S. Africa.

$A$. $B$. Specimens presented by E. L. Layard, Esq. (1860), J. A. S. XXIX, 88.

(Sub-genus Vandeleuria, Gray).

289. M. oleraceus, Bennett, P. n. S. 1831, 121.

Srn. M. dumeticola et M. povensis, Hodgson, Ann. Mag. N. H., XV, (1845), p. 269.

Hab. Plains of India, both N. and S.; Asám.

$A . B$. Stuffed specimens, and C. D. E. F. Examples in spirit. From S. India. Presented by W. Elliot, Esq., Madras C. S. (1842). G. Stuffed specimen, from Asám. Major Jenkins (1845).

290. M. GLiroides, Blyth, J. A. S. XXIV, 721.

Hab. Khásia Hills.

A. Specimen, with mutilated tail, in spirit. From Cherra Punji. Presented by F. Skipwith, Esq., C. S. (1855).

291. M. Badius, Blyth, J. A. S. XXVIII, 295.

HAB. Valley of the Sitang.

$A$. Specimen presented by Major Berdmore (1859).

* To the same particular group as the last four must be referred M. STRopIIatus, Hodgson, Ann. Mag. N. H., XV (1845), p. 268.

$\dagger$ Length about 4 in. ; tail $3 \frac{1}{4}$ in. Sparrman's deseription would seem to have been taken from the half-grown young.

$\ddagger$ A Conspectus of the species of Indian Rats and Mice will appcar in Vol. XXXI of the Journal of the Asiatic Society. 
(Sub-genus Leggada, Gray. Spiny field Mice.)

293. M. Jerdoni, Blyth, J. A. S. XXXI.

HaB. Sikhim.

A. Stuffed specimen. Presented by Dr. T. C. Jerdon (1862).

294. M. spinulosus, Blyth, J. A. S. XXIII, 734.

HAB. Punjab; S. Malabar.

$A$. Specimen in spirit, from the Punjab. Presented by Mr. Theobald (1854). C. D. Stuffed specimens, from S. Malabar. Presented by Rev. H. Baker, Junior (1860).

295. M. Platythrix, Bennett, P. Z. S. 1830, 205.

HaB, S. India.

A. B. Specimens presented by W. Elliot, Esq., Madras C. S. (1843).

296. M. Lepidus, W. Elliot, Madr. Journ. IV, 208, X.

Sxn. Leggada booduga (!), Gray.

HAB. S. India.

A. Specimen presented by W. Elliot, Esq. Madras C. S. (1843).

Genus Golunda, Gray.

297. G. Ellioti, Gray, Ann. M. N. H. (1836).

Syn. Mrus hirsutus, Elliot.

MI. coffeus, Kelaart, ' Coffee Rat' of Ceylon.

Golunda newera, Kelaart, Ann. M. N. H., 2nd series, VIII. (1851), p. 339.*

Hab. S. India; Ceylon.

$A$. Adult, and $B . C$. Young, in spirit. $D$. Stuffed specimen, S. India. Presented by W. Elliot, Esq. (1843). $\quad E$. Stuffed specimen from Ceylon. Presented by Dr. Kelaart (1856).

Genus Hydromys, Geoffroy.

298. H. Chrysogaster, Geoffroy; Ann. Mus. VI, 81, $t .36$, f.

* Our specimens, received both from Mr. Elliot and Dr. Kelaart, agree with the descriptions by Dr. Kelaart, and not with Mr. Elliot's description. Desd. G. meltada, Gray, M. N. H. I (1837), p. 586 ; v. M. lanuginosus, Elliot, Madr. Journ. Lit. Sc. X (1839), p. 212. 
Syn. H. fulvigaster, Jourdain.

Hab. Tasmania.

A. Specimen presented by C. G. T. Lloyd, Esq. (1860), J. A. S. XXVI, 315.

299. H. LEUCOGASTER, Geoffroy.

HAB. S. E. Australia.

$A$. B. Specimens from Port Philip. Presented by Mr. Benson (1849).

Genus Rhizomys, Gray (Nyctocleptes, Tem.; Aspalomys, Gervais.)

300. Rh. sumatrensis.

Syn. Mus sumatrensis, Raffles.

Nyctocleptes dekan, Temminck.

Spalax javanus, Temminck.

Rh. cinereus, McClelland.

HAB. Tenasserim Provinces; Malayan peninsula and archipelago.

A. B. Adults. C. D. Young, from Malacca. Presented by Mr. Frith and Mr. E. Lindstedt $(1846-8), \quad J . \quad A . \quad S . \mathrm{XVI}, 726 . \quad E$. Fine Tenasserim specimen. Presented by Major Tickell (1859), J. A. S. XXVIII, 411. $F$. G. Skulls, Tenasserim. Presented by Col. Phayre, J. A. S. XVII, 559. H. Skeleton from Mergui. Presented by Mr. Theobald (1855), J. A. S. XXIV, 711. I. Skull of young animal.

301. RH. Pruinosus, Blyth, J. A. S. XX, 509.

HaB. Khásya Hills.

A. B. C. Specimens from Cherra Punji. Presented by F. Skipwith, Esq. (1851-53), J. A. S. XXII, 580.

302. RH. BADIUS, Hodgson, Calc. Journal N. H. II, 60, 410.*

Sxn. Rh. minor, Gray, Ann. MI. N. H. (1842), p. 266.

HAB. Tárai region of Nipâl and Sikhim.

* I obtained the young of a peculiar RHrzomys in Upper Martaban : colour rather dark, with white occipital mark and white chin ; but it seems to be

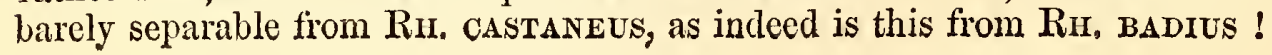


A. B. Adult and young, from Sikhim Tárai. Presented by W. T. Blanford, Esq. (1857), J. A. S. XXVI, 284.

303. Rir. Castaneus, Blyth, J. A. S. XII, 1007.

Syn. Rh. badius apud nos, J. A. S. XII, 925.

Hab. Burmese region, from Arakan to Mergui.

A. B. Specimens from Arakan. Presented by Colonel Phayre (1843). C. Skeleton of A. D. Specimen from S. Arakan. Presented by W. T. Blanford, Esq. (1862). $\boldsymbol{E}$. Example in spirit, from Mergui. Presented by Major Berdmore (1855), J. A. S. XXIV, 187.

Genus Castor, L.

284. C. europeus, Owen.

Srn. (?) C. gallia, Geoff., Mamm. Lithog. t.(apud Gray, Brit. Mus. Catal., Mammalia, p. 120).*

HAB. Europe (where now nearly extinct, though the race has been multiplied of late years, by the Austrian Emperor, in at least one of his extensive parks on the banks of the Danube); Siberia (at least formerly, vide Strahlenberg): A former inhabitant of the British Islands.

$A$. Stuffed specimen from Norway. Presented by the Royal University of Christiania (1844). (One of only two that had been killed in Norway during the preceding twenty years).

Genus Fiber, Cuv. (Ondatra, Lacepéde; Simotes, G. Fischer. $\dagger$

305. F.'Zibethicus.

Srn. Castor zibethicus, L.

\section{Ondatra americana, Tiedmann.}

* This name would hold precedence for the European Beaver, if it can be proved to apply to it specially.

$\uparrow$ This name was since applied by myself to a Cuculine genus of birds, based on the Cuculus leucolophos, S. Müller; and subsequently to one of Ophidia by MM. Dumeril and Bibron. 
('Muskquash' or 'Musk-rat,' of the AngloAmericans.)

Hab. N. America.

A. Stuffed specimen. Presented by Dr. Rüppell (1855), J. A. S. XXIV, 252.

Genus Arvicola, Lacepéde (Hypudaus, Illiger; Brachyurus, G. Fischer).

306. A. amphibia (Buffon, $H$. N., VII, $t .43$ ).

Sxn. Mius amphibius, M. terrestris, et $M$. paludosus, $\mathrm{L}$.

Lemmus aquaticus, F. Cuv.

A. aquatica (?), de Selys Longchamps.

A. destructor (?), Savi, apud Gray.

HAB. Europe.

$A$. B. Stuffed specimens from England. Presented bv Mr. Bartlett (1842). C. Another. Presented by Col. R. C. Tytler (1862). $D$. One entire in spirit. From the Christiania, University (1846). $E$. Black stuffed example. Presented on the part of the Montrose museum, by A. Mitchell, Esq. (1855).* $F$. Skeleton. Presented by J. H. Gurney, Esq. (1860), J. A. S., XXIX, 206.

307. A. Nivalis, Martin, Ann. des. Sc. Nat., 1843.

Syn. Hypudaus alpinus, Schreber.

HAB. Swiss mountains, near the snow-line.

A. Specimen from Mt. St. Gothard. Presented by Mons. A. Malherbe (1842).

308. A. GLAREOla (Schreber, $t .190, b$ ).

Srn. M. glareolus, Schreber.

$M$. rutilus, var., Pallas.

A. riparia, Yarrell.

A. fulvus, Millet.

A. rufescens, Selys.

A. pratensis, Baillon.

* Long before leaving England (1841), I was assured of the existence of a black race of this animal in Aberdeenshire ; as also of the large race of Mus sylvaticus, in the Highlands of Scotland, of which the Society's museum contains specimens from France and Switzerland. 
Hypudaus hyrcinicus, Michelis.

Lemmus rubidus, Baillon.

Hab. Europe; N. and W. Asia.

A. Large race. A.B. C. Stuffed specimens from France. Presented by Mons. A. Malherbe (1842). B. Small race. D. E. F. G. Examples from England. Presented by Sir W. Jardine, Bart. (1848), J. A. S., XVII, 247. H. Example in spirit, from Norway. Presented by the Christiania University (1846).

309. A. arvalis (Buffon, N. H., VIII, $t .47$ ).

Syn. IMus arvalis, Pallas.

$M$. gregarius, $\mathrm{L}$.

M. terrestris, Erxl.

A. vulgaris et A. fulvus (?) Desm.

A. agrestis, Yarrell.

Hab. Europe; N. Asia.

A. B. C. Stuffed specimens from England. Presented by Mr. Bartlett (1843).

311. A. Roylei, Gray, Ann. M. N. H., X (1842), 265.

Hab. Punjab; Kashmir.

A. Stuffed specimen from Pind Dádun Khán. Presented by W. Theobald, Esq. (1853).

Genus Neodon, Hodgson, Ann. Mag. N. H., 2nd series, III (1849), p. 203.

311. M. sikhimensis, Hodgson, loc. cit.

$\mathrm{H}_{\mathrm{AB}}$, S. E. Himálaya (7,000 to 15,000 feet). $A$. Specimen from Dorjiling. Presented by Major W. S. Sherwill (1853), J. A. S. XXII, 409.

Genus Phaiomys, Blyth, J. A. S. XXXI (1862).

312. M. LeuCurus, Blyth, loc. cit.

HAB. Tibet.

A. Specimen. Presented by W. Theobald, Esq., Junior (1862).

Genus Mrodes, Pallaṣ. 
313. M. Lemuus (Pallas, Glires, $t .12, a$ ).

Srn. Mus lemmus, L.

II. norvegicus, Worm.

II. lemmus v. norvegica, Pallas.

HAB. N. Scandinavia.

A. B. Specimens presented by the Christiania University (1844), and M. Alfred Malherbe (1849), J. A. S., XVIII, 30.

Genus Myospalax, Blyth.

314. M. Fuscocapillus, (J. A. S. XV, 141).

Srn. Georhychus fuscocapillus, Blyth, J. A. S. X. 928, XV, 887, XIV, Proc. October, 1845, p. ciii : 'Quetta Mole' of some writers.

Hals. Afghánistân (Quetta).

A. B.C. D. Stuffed specimens. Presented by Capt. T. Hutton (1846). E. Skull, $J$. $A$. S. X, 928.

Genus Spalax, Guldenstein (Aspalax, Olivier; Aspalomys, Laxmann; Ommatostergos, Keyserling and Blasius).

315. Sr. Typhlus (Pallas, Glires, 76, 154, t. 8).

Syn. DIus typhlops, Pallas.

Sp. micropthalmus, Guldenstein.

Sc. major, Erxleben.

Hab. Syria.

A. Stuffed specimen (not in good condition): the animal found dead on the summit of a small mound near Beyrout. Presented by J. C. Parker, Esq. (1855), J. A. S. XXIV, 188.

Fam. BATHYERGID瓜 (African).

Genus Bathyergus, Illiger.

316. B. maritimus (Buffon, $N$. S., Supp. XXIV, t. 10).

Syn. Mus maritimus, Gmelim.

MI. suillus, Schreber.

Arctomys africanus, Thunberg.

Orycterus maritimus, F. Cuvier.

Fossor ca pensis, Forster. 
Hab. S. Africa.

A. B. C. Stuffed specimens. Presented by Major W. S. Sherwill (1853), XXII, 409. D. Presented by E. L. Layard, Esq. (1860), J. A. S. XXIX, 99.

Genus Georhychus, Illiger.

317. G. Capensis (Buffon, Supp. III, 193, t. 33; Pallas, Glires, 76, t. 7).

Syn. Mus capensis, Pallas.

Fossor leucops, Forster.

$\mathrm{H}_{\mathrm{AB}}$. S. America.

A. Stuffed specimen. Presented by E. L. Layard, Esq. (1860), J. A. S. XXIX, 100.

318. G. CACUTiens.

Syn. Bathyergus cacutiens, Lichtenstein.

$B$. hottentotus, Lesson.

B. Ludwigii, A. Smith.

Hab. S. Africa.

A. B. C. Stuffed specimens. Presented by Major W. S. Sherwill(1853), and E. L. Layard, Esq. (1860), J. A. S. XXIX, 190.

Fam. OCTODONTIDA (S. American).

Genus Octodon. Bennett.

319. O. DEGUS (Tr. Z. S. II, $81, t .16$ ).

Syn. Sciurus degus, Molina.

O. Cumingii, Bennet.

Callomys aureus, d'Orbigny.

Myoxus gelatinus, Poëppig.

Нав. Chili.

$A$. Specimen presented by C. T. Eyton, Esq. (1849).

Genus Spalocopus, Wagler.

320. Sp. Pö́eppigir (Voy. de la 'Favortte', I, 17, pl. 7). Syn. Poephagomys ater, F. Cuv.

Psammoryctis noctivagus, Poëppig.

Hab. Chili. 
A. Specimen presented by C. T. Eyton, Esq. (1849).

Fam. HYSTRICIDAE.

Sub-fam. DASYPROCTINAE.

Genus Carlogenys, Illiger.

321. C. PaCa (Schreber, Saugth. IV, 609, t. 171).

Srn. Mus paca, L.

C. fulvus et C. subniger, F. Cuv.

Osteopera platycephala, Harlan.

Hab. S. America.

A. Specimen from Mr. Bartlett (1849), J. A. S. XVIII, 87.

Sub-fam. HYSTRICINAE.

Genus Hrstrix, L.

322. H. Leucura, Sykes (Waterhouse, Rodentia, p. 454).

SYN. H. hirsutirostris, Brandt.

H. zeylanensis, Blyth, J. A. S. XX, 171 (young).

Hab. Upper India; Afghánistân; Dukhan; Ceylon.

$A$. Small adult, from Vizigapatam, stuffed. $B$. Young. $C$. Stuffed head of a large individual, from $\mathrm{S}$. India. Presented by the Hon. W. Elliot, Madras C. S. (1843-59), J. A. S. XXII, 414. D. Young, from Cey* lon. Presented by Dr. Kelaart (1851). E. to $K$. Series of six.skulls; two from Ceylon, presented by Dr. Kelaart (1851); one from Pind Dádun Khán, presented by W. Theobald, Esq., Junior (1853).

333. H. bengalensis, Blyth, J. A. S. XX, 179.

HAB. Bengal; Asám; Arakan.

$A$. B. Adults, stuffed, one received from Barrackpore, $J$. A. S. XXII, 584 ; the other by E. Lindstedt, Esq.; J. A. S. XVI, 863 (1847). C. Young, ditto. D. Skeleton of adult. Presented by Bábu Rajendra Mallika and the Curator (1845-56). 
334. H. LONGICAUda, Marsden.

Srv. Acanthion javanicum, F. Cuv.

H. Hodgsonii, Gray.

A. alophus, Hodgson.

Hab. Nipâl ; Sikhim; Arakan; Indo-Chinese region; Malayan peninsula; Sumátra; Java; Borneo.

A. Specimen from Malacca, stuffed; from Society's old collection. B. Ditto, received from Dorjiling. Presented by the Curator (1832). C. Young, from Arakan. D. Large imperfect skin, from Nipâl. Presented by B. H. Hodgson, Esq. (1836).

Genus Atherura, Cuvier.

335. Ath. Fasciculata (Buff., Supp. VII, 303, $t$. 77 ).

Syn. Hystrix fasciculata, Shaw.

H. macroura, Gervais, J. A. S. XX, 519.

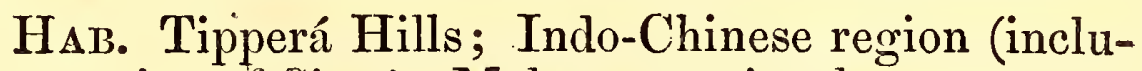
sive of Siam); Malayan peninsula.

$A$. Stuffed specimen from Tipperá, with $A$, a. Skull. Presented by R. W. G. Frith, Esq. (1851). B. Another, from Malacca, with $B, a$. Skull. Presented by the Rev. A. W. Lindstedt (1859). C. Another, from the Society's old collection, J. A. S. II, 97.

Fam. CAVIAD $\mathbb{E}$.

Genus Cavia, Klein.

336. C. australis, Is. Geoffroy (Mag. de Zool, 3 tome, pl. 129).

SYN. Kerodon Kingii, Bennett.

HAB. Patagonia.

A. Stuffed specimen. Presented by C. T. Eyton, Esq. (185 ).

337, C. cobaya, Marcgrave.

Syn. Mus porcellius, L.-Domestic 'Guinea Pig.'

Hab. S. America, where discovered by the Spaniards, tame among the aborigines. 
A. B. C. D. Stuffed specimens. E. Skeleton. $F$. $G$. Skulls. Presented by the Curator and others.

Fam. PECTINATORID E.*

Genus PeCtinator, Blyth, J. A. S. XXIV, 294.

338. P. Spekei, Blyth, loc cit.

Haв. Somâli-land.

$A$. Stuffed specimen, and $A$, a. Skull.

Presented by Capt. Speke (1855).

Fam. LEPORID 2 .

Genus Lepus, L.

( $A$. African type, with enormously long ears.)

339. L. Saxatilis, F. Cuv. (Waterhouse, Rodentia, p. 92).

Syn. L. rufinucha, A. Smith.

L. longicaudatus, Gray.

L. fumigatus, Wagler.

HAB. S. Africa.

A. Stuffed specimen. Presented by E. L. Layard, Esq. (1860), J. A. S. XXIX, 100.

340. L. Capensis, L. (Waterhouse, Rodentia, p. 95).

SYn. L. ochropus, Wagler.

L. arenarius, Is. Geoffroy.

Hab. S. Africa.

$A$. Stuffed specimen. Presented by E. L. Layard, Esq. (1861), J. A. S. XXIX, 100.

(B. European species.)

341. L. Timidus, L. (Buffon, H. N. VI, 247, pl. 38).

Syn. L. europaus, Pallas.

Hab. Europe (nec Scandinavia, nec Ireland, till recently introduced); Persia.

$A$. Stuffed example. Presented by $\mathrm{Mr}$. Bartlett (1842). B. Skulls. Ditto.

* A remarkable African family, comprising the Crenodactruus of Gray; and most nearly akin to the CHINCHILLID of the Andean region of S. America. 
342. L. variabilis, Pallas (Bell's Br. Quadr., p. 35).

Syn. L. albus, Brisson, var.

L. hibernicus, Bell.

L. timidus, var. B. Jenyns.

HAB. Mountains of Europe, N. Asia; slight variety in Ireland.

$A$. Summer dress. $B$. Winter dress (imperfect), from Scandinavia. Xia Univ., 1844. C. D. Winter dress (not quite complete), from Scotland. Presented by Sir W. Jardine, Bt., J. A. S. XVI, p. 247. E. F. $G$. Skulls. Presented by Mr. Bartlett. $H$. Stuffed specimen from Ireland; and $I$. Skull. Presented by Mr. Bartlett (1842).

343. L. cuniculus, L. (Waterhouse, Rodentia, p. 64).

Syn. L. magellanicus, Lesson and Garnot.

Hab. Europe; N. Africa.

A. B. Wild Rabbits from England; and C. D. Skulls. Presented by Mr. Bartlett (1852). E. F. Domestic lob-eared variety. Presented by Bábu Rajendra Mállika (1847). $G$. Skull; and $H$. Stuffed head; with distorted teeth.

(C. Asiatic species).

344. L. Pallipes, Hodgson (J. A. S. XI, 288, and plate).

Syn. L. tolai, Pallas, apud Gray.

Hab. Tibet.

A. Imperfect skin. Presented by —

345. L. Ruficaudatus, Geoffroy (1826), Vide J. A. S. $\mathrm{XI}, 100$.

Syn. L. indicus, Hodgson (1834).

$L$. macrotis, Hodgson (1840).

L. orientalis, Brown (1836).

L. timidus, var., McClelland; L. timidus et

L. ruficaudatus apud Walker, from Asám, Calc. J. N. H. III, 267. Tibet.

* Desid. L, mibetanus, Waterhouse (vel oistolus, Hodgson), also from 
L. Tytleri, Tytler, Ann. M. N. H. 1854, p. 176, from Dacca; J. $A$. S. XXII, 415, XXIV, 471.

Hab. Bengal; Upper India; (Kandahar?); S. Malabar ; low country Hare of Ceylon? J. A. S. XXVIII, 291, P. Z. S. 1850, 157. $A$. Specimen obtained in the Calcutta bazar. $B$. C. Young. Ditto. D. Skeleton, ditto. $E$. Bad stuffed specimen from Dacca $(L$. Tytleri, Tytler). F. Skull of Kandahar Hare, perhaps of a nearly allied species, vide $J . A$. S. XV, 141). Presented by Capt. T. Hutton (1846).

346. L. Peguensis, Blyth, J. A. S. XXIV, 471.

Syn. Supposed L. sinensis, J. A. S. XXI, 359.

Hab. Upper Pegu.*

$A$. Stuffed specimen. B. Skull. Presented by Col. Phayre (1855).

347. L. sinensis, Gray (Hardwicke's Ill. Ind. Zool.; not good: J. A. S. XXX, 90).

HAB. China.

$A$. B. Stuffed specimens; and C. Skull. Presented by R. Swinhoe, Esq. (1861.)

448. L. Nigricollis, F. Cuv.

SYN. L. melanauchen, Temminck (from Java).

L. kargusa, B. H., apud Gray !†

Hab. "Sindh ; Dukhun; Punjáb; not the Himálayas." (A. Leith Adams.) Not Bengal (where erroneously stated to inhabit by Mr. Waterhouse). Ceylon. Introduced into Jáva and the Mauritius.

$A$. Specimen from S. India. Presented by Mr. Elliot (1843). B. Ditto from Ceylon. Presented by Dr. Templeton (1849). C. Ditto from Jáva. Presented by the Batavian

* A speeies of Hare, probably this one, is stated to inhabit the right bank of the Salwin, above the junction of the Yunzalin river.

$\uparrow$ Buchanan Hamilton merely referred to the animal by its common native name of Khurgus, or 'Ass-ears.' 
Society (1844). D. Ditto from the Mauritius. Presented by Willis Earle, Esq. (1843). (Caprolagus, Blyth.)

449. L. (C.) IIIspidus, Pearson, Beng. Sp. Mag., 1843, p. 130.

Srn. Caprolagus hispidus apud Blyth (J. A. S. XIV, 247, pl.).

HАв. Asám; Rajmáhal Hills ; common about Dacca.

A. Stuffed specimen from Asám, with $B$. Skull, from Asám. Presented by Major Jenkins (1845). C. Skeleton, from Rajmáhal. Presented by Major W. S. Sherwill (1853).

Genus Lagomys, Pallas.

450. L. Roylei, Ogilby (Royle's Ill. Him. Bot., pl.)

Srn. L. Hodgsonii, Blyth.

L. nipalensis, Hodgson; J. A. S. X, 416, $854,816$.

HAB. Ladakh; Kashmir, \&c. Choor mountain, near Simla.

A. B. C. D. E. F. Series of six specimens, and two skins (additional), illustrative of the variation of colour. Presented by Col. A. Broome, Major T. Blagrave, Mr. Hodgson, Major W. S. Sherwill, Mr. 'Theobald, and others. G. H. Skulls.

451. L. RUfescens, Gray (Waterhouse, Rodentia, p. 21). Had. Afghánistân.

$A$. Stuffed specimen, and $B$. Skull. Presented by Capt. T. Hutton (1846), J. A. S. $\mathrm{XV}, 14 \mathrm{i} . *$

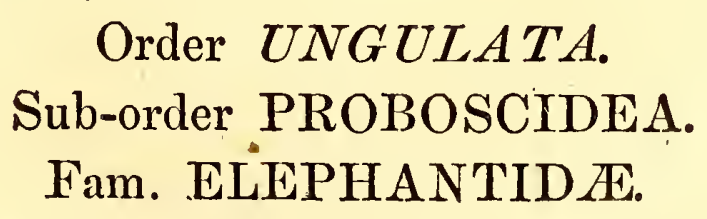

Genus Elepinas, L.

* Desid, L. Curzoniz, Hodgson, from Tibet, Ann. M. M. H., n s., I (1858), p. 80.-Lagomys, from Ladakh, No. 35 (?), A. L. Adams, P.Z. S. 1858, p. 520. 
E. Indicus, L. (Ph. Tr. 1799, t. 5-12; F. Cuv., Mamm. Lithog. III, 86):

Syn. E. maximus, L.

$\boldsymbol{E}$. asiaticus, Blumenbach.

Hab. India ; Indo-China ; Malayan peninsula (?); S. India (?)

N. B.-The Elephant of Sumátra and also of Ceylon is considered by Professor Schlegel and others to be a distinct species, E. sumatranus, Schlegel: those of S. India and of the Malayan peninsula need further critical examination. The wild Elephant of Burmá is true Indicus. Vide J. A. S. XXXI, 17]).

$A$. Skeleton of adult male. Presented by His late Majesty Nussir-ud-Dowlá, King of Oudh, in 1839 (J. A. S. VIII, 688). B. Large skull (tusks wanting). C. Split skull, to show the brain cavity. D. Another skull. $E$. Scapula. Presented by the late Dr. Wallich (1816), As. Res. XII, App. p. XXVI. F. Large skull (tusks wanting in ail), save that on the skeleton. Presented by G. Burney, Esq., in 1822, As. Res. XIV, App. G. Skull without lower jaw. Presented by - $H$. Skull of new-born young. Purchased (1856). I. J. Two large tusks (one remarkably bulky; the other unusually long and slender and beautifully curved): Presented by His Excellency General Bhimá Sinhá, in 1836, J. A. S. V, 56. K. Another tusk. Presented by R. Home, Esq., As. Res. XII, App. XXV. L. Tusk of female; and $M$. Milk-tusk. Presented by $-N$. Concretion found in the tusk of a Malabar Elephant. Presented by the Rev. H. Baker, junior, J. A. S. XXVIII, 291.-Numerous specimens of molar-teeth. Some presented by W. Masters, Esq., in $1842, J$. $A$. S. XI, 96. One of a Burmese wild Elephant: presented by W. T. Blanford, Esq. (1862).

Sub-order PERISSODACTYLI.

Genus Tapirus, L. 
T. malayanus, Raffles (Zool. Journ., pl.; F. Cuv. Mamm. Lithog. I, 87.)

Syv. T. indicus, Cuv.

T. sumatranus, Gray.

HАв. Sumátra; Malayan peninsula, and Southern Tenasserim provinces (as high as Yé).

$A$. Skeleton, and B. Stuffed 'skin, both prepared from the same female individual, in 1844. Presented by J. Agabeg, Esq. C. Skull of adult. Presented by Major Farquhar, in 1820, As. Res. XIII, App. XVII, J. A. S. IX, $517 . D$. Skull of young, from the injured skeleton. Presented by Dr. McCosh, in 1837, J. A. S. VI, 897. E. F. Imperfect skin, and skull, of full-grown fœtus, from Malacca. Presented by E. Lindstedt, Esq. (1848).

\section{Genus Equus, L.}

EQ. caballus, L.

$A$. Skeletón of English racer $(J . A . S . \mathrm{IX}$, 529). $B$. Ditto of new-born racer foal (J.A.S. XIX, 561). Presented by Messrs. Hunter and Co., of Calcutta. C.D.E. F. G. H. I. Series of seven skulls. Presented by Mr. W. Masters, Dr. Crozier (J. A. S. XXVIII, 507), and others.

(Sub-genus Asinus, Gray.)

EQ. ASINUS, L.*

Syn. Asinus vulgaris, Gray.

HAB. Aboriginally from N. E. Africa, S. Arabia, and island of Socotra, vide J. A. S. XXVIII, 243, 411, XXXI,

$A$. Skeleton of small Indian domestic race, from the Society's old collection.

EQ. onager; E. asinus onager, Pallas (F. Cuv., Mamm. Lithog. II, t. 92).

* Desid.-E. hemippus, Is. Geoffroy, of Syria, Mesopotamia, and N. Arabia ; E. Asinus ferus; and the three striped species from Africa. 
Syn. E. hemionus of India, Persia, and hither portion of W. Asia, auctorum.

Haв. W. Asia, from $48^{\circ}$. N. lat., southward to Fersia, Beluchistán, and W. India.

$A$. Skull, and $B$. Flat skin, from Kandahar. Presented by Major H. B. Lumsden, in 1859 (J.A. S. XXVIJI, 237, 411).

A. inemionus, Pallas (nec Comm. Petrop.t. 7).

Srn. A. kyang, Moorcroft (Strachey, J. A. S. XXIX, 136.)

A. equioides et polyodon, Hodgson.

Hab. The Tibetan region, and E. Turkistán. (Vide P. Z. S. 1858, p. 531.)

$A B$. Adult and young, stuffed, from specimens sent down by Dr. Campbell in 18 . C. Another skin, not mounted. Presented at the same time by Dr. Campbell. $D$. Skull, and $\boldsymbol{E}$. Limb-bones, taken from a skin forwarded by G. T. Lushington, Esq., C. S., in 1838 (J. A. S. XVII, 144).

E. zebra, L. (F. Cuv., Mamm. Lithog. III, 88.)

SYN. E. montanus, Burchell.

E. indicus, Johnstone's Quadr.

E. braziliensis, Jacob, apud Gray.

HAB. Mountainous regions of S. Africa.

A. Imperfect skin. Purchased.

FAM. RHINOCEROTIDIE.

Genus Rhinoceros, L.

RH. Indicus, Cuvier (Mem du Mus, t. ; J. A. S. XXXI, p. 155).

SYN. Rh. unicornis, L.

Rh. asiaticus, Blumenbach.

Rh. inermis, Lesson.

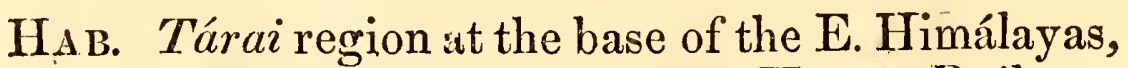
inclusive of the valley of the Upper Bráhmaputra, or province of Asám.*

* Skulls immediately expected. 
460. RH. sondaicus, S. Müller (Horsf., Zool. Res. in Java). Syn. Rh. javanicus, F. Cuv.; Mamm. Lithog. I, pl. 85,86 .)

HaB. Rajmáhal hills (where now verging on extirpation); Bengal Sundarbáns; Indo-Chinese region; Malayan peninsula; Jáva; Borneo: Upper Siam ; Cambodia ; province of Quangsi, in China (?).

A. Stuffed specimen, under $3 \frac{1}{2}$ feet high. Carcass presented by C. Huffnagle, Esq., in 1850 (J. A. S. XIX, 88). B. Skeleton of nearly full-grown female, not quite complete (vide J. A. S. X, 928); the animal killed in the Jessore district, and presented to the Society by J. H. Barlow, Esq., in 1834 (J. A. S. III, 142, IX, 518). C. D. E. F. G. H. Series of skulls, one of them young; one (with horn) from Jáva, presented by the Batavian Society in 1846; three from the Tenasserim provinces-two of them presented by Sir T. H. Maddock, in 1842 (J.A. S. XI, 448)-the third (with horn), from near Tavoy Point, presented by Col. A. Fytche, in 1861 (J.A.S. XXXI, 159). The remaining arlult is that noticed by Dr. Pearson in J. A. S. IX, 518 (being probably one of the five presented by Dr. Wallich, as recorded in As. Res. XII, App. XXVI). I. Bones of right hind-foot of a young animal, articulated. Presented by Dr. Pearson in 1836, and noticed in $J . A$. $S^{*}$. IX, 524.

461. Rh. sumatranus, F. Cuv. (Phil. Tr. 1793, pl. ; S. Müller, pl. ; Mamm. Lithog. II, 83.)

Srn.? Rh. cucullatus, Wagler, vide J. A. S. XXXI, 154.

HaB. Burmese countries; Malayan peninsula; Sumátra. (Rare in Asám.)

$A$. Stuffed head of adult female. B. Skull, axis vertebra, left scapula, humerus, radius and ulna, and long bones of both hind-limbs, of the same individual. $C$. Skull, and $D$. Scapula and long bones of the fore-limbs, of 
an old male, from the Tenasserim provinces. Presented by E. O'Reilly, Esq., in 1847 (J. A. S. XVI, 210, 502). E. F. Skulls (one minus lower jaw), also from the Tenasserim provinces. Presented by Sir T. Herbert Maddock, in 1842 (J. A. S. XI, 448). $G$. Facial bones of an old individual with small horns. Procured by the Curator near Pahpoon, on the Yunzalin river, Upper Martaban, in Nov. 1861. $H$. United nasal bones, being probably the "part of the head of a two-horned Rhinoceros," recorded as presented by Miss Lloyd, in As. Res. XIII, App. XVIII, in which case probably from Sumátra.*

462. Rh. africanus, Desm. (A. Smith, S. African Zoology, Mamm., pl. 2.)

SYN. Rh. bicornis, L.

$R h$. Brucei et $R h$. Gordonii, Blainville.

Rh. niger et Rh. Camperi, Sichinz.

$\mathrm{H}_{\mathrm{AB}}$. Africa, from the Galla country to the C. of G. Hope.

A. B. Anterior horns. Presented by Major W. S. Sherwill in 1843 (J. A. S. XII, 65).

463. RH. simus, Burchell (A. Smith, S. African Zoology, Mamm., pl. 19).

Syn. Rh. Burchellii, Desm.

Rh. camus, Griffith, $A n$. K., V, 746.

Hab. S. Africa, chiefly north of Tropic of Capricorn.

$A$. Anterior horn. Presented by Major W. S. Sherwill, in 1846 (J.A. S. XV, ).

Fam. HYRACIDA.

Genus Hyrax, Hermann.

464. H. CAPEnsis ; Cavia capensis, Pallas (Misc. t.)

Hab. S. Africa.

* " The horn of a Rhinoceros, from Sumátra," recorded as presented by Lieut. Seymour, in As. Res. XIII, App. XIX, and also the "two Rhinoceros-horns," presented by R. Home, Esq., as recorded in As. Res. XII, App. XXII, were uot in the Society's museum when I took charge of it in 1841 . 
A. B. C. D. Adult male and female, and two young, stuffed. $E$. $F$. Skulls of adults. $G$. Ditto of young; one of the former from the summit of Spitz-kopf mountain (10,250 feet above the sea). $H$. Examples of the curious crecum of the animal, inflated. All presented by Major W. S. Sherwill, in 1843 and 1850 (J. A. S. XII, 65, XIX, 88).

465. H. Habessinicus, Hemprich and Ehrenberg (Symbola Physica, $t$. ).

SyN. H. zamar, Cuvier.

H. syriacus, Schreber, apud Rüppell.

Ha B. E. Africa.

A. Stuffed specimen from Somâli-land. Presented by Capt. Speke, J. A. S. XXIV, 296 (1855).

Fam. SUID Æ.,

Genus Phacochares, Cuvier.

466. Рh. athiopicus; Aper athiopicus, Pallas (Misc. XVI, t. 2, $S p . Z$. II, 3,t. 1, XI, 80).

SYN. Sus athiopicus, L.

Ph. africanus, Desmarest.

Ph. edentulus, Is. Geoffroy.

Hab. S. Africa,

A. Imperfect skull of male, minus lower jaw, from Port Natal (referred by the donor to Sus larvatus in $J$. $A$. S. XII, 65). Presented by Major W. S. Sherwill, in 1843.* $B$. A tusk.

Genus Sus, L.

467. Sus scropha, L.

$\mathrm{H}_{\mathrm{AB}}$. In various distinguishable wild races, Europe, Asia, and N. Africa.

* A "skull of Ethiopian Hog, with its tusks, from Caffraria," is recorded in As. Res. XIV, App. XIV, to have been presented by Capt. Peach. This is not mentioned in Dr. Pearson's Catalogue, J. A. S. IX, 514 et seq. 
A. Skeleton of domestic Indian boar. Presented by Dr. A. R. Jackson, in 1837 ( $J$. A. S. VI, 79). Approximates in size and appearance to the wild race of the Tenasserim provinces.

A. S. bengalensis, Blyth, J. A. S. XXIX, 105 (XX, 173). Race with wide occipital plane (commonly $2 \frac{1}{4}$ inch where narrowest), and broad convex frontal region. The true Bengal boar. HAB. - Bengal, to foot of Himálaya; Asám (?); Sylhet (?); Arakan.

$A$. Stuffed specimen. The speared carcass presented by R. Stopford, Esq., in 1834. $B$. Two foetuses, in spirit. Presented by Mr. J. T. Babanau, J. A. S XVII, 251 (1843). C. Skeleton, from Kishnaghur. Presented by J. E. Laidlay, Esq., in 1858. D. E. Skulls of boars, one of them from the Grorruckpore tarai. Presented by J. C. Peppé, Esq., in 1847 (J. A. S. XVI, 863). F. Skull of sow from Arakan. Presented by Col. Phayre (1846). (In general, skulls from the Gorruckpore tarai differ somewhat in form, but are undoubtedly referable to this particular race. They have the same broad convex forehead, but the occipital plane does not exceed 2 inch in width). $G$. Very large skull, the upper and lower right tusks wanting, those on the left side broken. (Length, from occiput to tips of

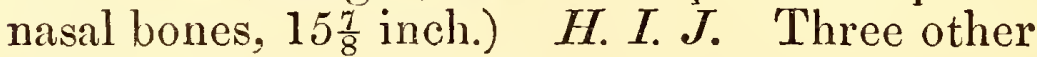
skulls, smaller, all more or less imperfect; and the four presented by J. C. Peppé, Esq., in 1862, from the Gorruckporc tarai.

B. Sus indicus apud Blyth, J. A. S. XXIX, 105 ; S. cristatus, Wagler. With medium occipital plane (commonly $1 \frac{1}{2}$ inch wide where narrowest), and flatter frontal region. The wild Hog of India generally and of Ceylon. $K$. Fine skull of boar, from Cuttack. Presented by J. Shave, Esq., in 1845. L. Skull of sow, from Punjáb Salt Range. M. That of a younger sow, from Ditto. Both presented 
by W. Theobald, Esq., J. $A$. S. XXII, 583 (1853). $N$. Skull of wild boar, the head purchased by the Curator in Akyab bazar (1861); the occiput injured, but its dorsal plane appears to have been unusually narrow. $O$. Aged boar. $P$. Adult ditto. $Q$. Young (wanting the lower jaw), from Ceylon. Presented by Dr. Kelaart, in 1851. $R$. Facial portion of the skull of a small pig, from the Nicobars (probably a domestic animal). Presented by Capt. Hodge, in 1860, J. A. S.

$C$. Tenasserim race: like $S$. indicus, but onefifth smaller in linear dimensions; the tusks of the boar well developed. S. Skull from the Society's old collection, being that (and the only specimen !) noticed in Dr. Pearson's Catalogue, J. A. S. IX, 509 (length, from middle of occiput to point of nasals, $12 \frac{1}{2}$ inch). $T$. Another. Presented by ? (as that of a wild sow, bearing tusks like those of a boar). With the habitats of these two specimens I am unacquainted; but they exactly accord with skulls from the Tenasserim provinces.

D. S. zeylanensis, Blyth, J. A. S. XX, 173, 185.

Hab. Ceylon.

$N$. Skull. Presented by Dr. Kelaart, in 1850, vide loc. cit.

468. S. andamanensis, Blyth, J. A. S. XXVII, 267, XXVIII, 271, 282.

Hab. Andamán Islands (inclusive of the Little Andamán); Nicobars (?); * Sumátra (?), vide J. A. S. XXIX, 104.

$A$. Skeleton of adult boar. Presented by Capt. Hodge, in 1860 (J. A. S. XXIX, 103). $B$ to $K$. Series of ten skulls, of different sexes and ages; mostly perfect. Presented

* Not the large domestic race of the Nicobars, noticed in $J . A$. S. XXVII, 290. I have been assured that there are diminutive wild pigs in the Southern Nicobars. 
by Dr. Liebig, Dr. Mouat, and Lieut.-Col. Tytler (1851-62).*

Genus Potamochorus, Gray.

469. P. AFricanUs; Sus africanus, Schreber (Wolf's Sketches, pl. ).

Syn. Sus chœropotamus, Desmoulins.

S. larvatus, F. Cuvier.

HAB. S. Africa.

$A$. Stuffed skin (without skull). Presented by Dr. Rüppell, in 1855 (J.A.S. XXIV, 252).

Genus Babyrussa, F. Cuvier.

470. B. AlFurus, Lesson (

SYN. Sus babyrussa, L.

Aper orientalis, Brisson.

Hab. Celebes, Buru, and Ternate.

$A$. B. Skulls. "Two skulls of the Babyrussa, from Amboyna," are recorded in the As. Res. XII, App. XXII, as having been presented by J. Dunlop, Esq.; and in p. XXVI, ibid, "a skull of the Babyrussa" as presented by Dr. Wallich. Two of them only are noticed in Dr. Pearson's Catalogue (J. A. S. IX, 519).

Fam. HIPPOPOTAMID $\AA$.

Genus Hippopotamus, L.

471. H. Capensis, Desmoulins (vide Leidy; Smith's $S$. African Zoology, Mamm., pl. ).

HAB. S. Africa.

$A$. Skull of aged female. Presented by Dr. Wallich, in 1844. $B$. Anterior portion of lower jaw of large male. Presented by Major

* Desid. Porcula salvania, Hodgson, J. A. S. XVI, 423, 593, XVII, 475. The Pygmy Hog of the Nipâl and Gorruckpore tarai. Also the various wild species of the Asiatic Islands, vide $J . A$. S. XXVII, 268. While this sheet is passing through the press, numerous skulls of Sus andamanensis have been received from Lient.-Col. Tytler, and also a living adult sow, which I have shipped for England. 
W. S. Sherwill, in 1843 (J.A. S. XII, 65). $C$. Lower tusks and great incisors of male; ditto of female; and a thong of the hide. Presented by the same. $D$. Lower tusk of male, from the Society's old collection, as noticed (J: A. S. IX, 525).

Sub-order SYRENIA.

Fam. HALICORID A.

Genus Halicore, illiger.

472. H. DUGONG; Trichechus dugong, Erxleben (F. Cuv. Mamm. Lithog. II, 120 ; Zool. Astrolabe, Atlas, pl. 27).

Syn. H. cetacea, Illiger.

H. indica, Desmarest.

H. tabernacularum, Rüppell (apud Gray).

Dugongus marinus, Tiedemann.

$\mathrm{H}_{\mathrm{AB}}$. Indian Ocean.

A. Lower jaw, two scapulæ, and four ribs, of a nearly half-grown individual, found in an Andamánese hut (or lair). Presented by Capt. Niblett, in 1859 (J. A. S. XXVIII, 271). $B$. Lower jaw of an adult, also from the Andamáns. Presented by Lieut.-Col. Tytler, in 1862.

473. H. australis, Owen.

HAB. N. E. and W. coasts of Australia; also of N. Guinea.

$A$. Skull, with lumbar and caudal portion of vertebral column of adult. From the Gulf of Carpentaria. Presented by Dr. R. Tytler, vide Corbyn's India Review, III, 46 (1838), and $J$. $A$. S. XXVIII, 494.

Sub-order RUMINANTIA.

Tribe Ancerata.

Fam. CAMELID Æ.

Genus Camelus, L.

474. C. dromedarius, L. (Menag. Mus., $t_{\text {。 }}$ ) 
- Syn. C. dromas, Gesner.

C. Arabice, Pliny.

C. arabicus, Desmarest.

C. vulgaris, Forsk.

C. monotophus, Walther.

HAB. In the domestic state, from the Ganges to Senegal; a very distinct race in W. Asia. Wild Camels (indigenous?) abound, according to Rïppell, in the desert bordering the western shore of the Red Sea.

$A$. Skeleton of male. Presented by the late King of Oudh, Nussir-ud-Dowlah, in 1839 (J. A. S. VIII, 688). Skull of female. Presented by Lieut.-Col. R. Tytler, in 1861.

Genus Auchenia, Illiger.

475. Auch. glama, Desmarest (F.Cuv., Mamm. Lithog. II, 95 ).

Syn. Lama peruana, Desmarest.

Hab. Andes (known only in the domestic state). A. Skeleton. Presented by the late Earl of Derby to the Curator, in 1850 (J.A.S. XIX, 426).

Tribe Pecora.

Genus Camelopardalis, Gmelin.

476. C. Giraffa, Gmelin (F. Cuv., Mamm. Lithog., $t$. ).

SyN. Giraffa camelopardalis, Brisson.

Cervus camelopardalis, L.

Camelopardalis sennaarensis, et

C. capensis, Geoffroy.

Hab. Africa.

$A$. Skeleton of male. Carcass presented by the Right Hon'ble Earl Canning, in 1862. $\not B$. Skeleton of female. Presented by the Right Hon'ble Viscount Hardinge, in 1847 (J. A. S. XVI, 209). C. Bezoar, taken from the stomach of a Giraffe. Presented by the Máharája of Burdwán, in 1859 (J. A. S. XXVIII, 282). 
Fam. CERVID A

Sub-fam. $A L C I N A E$.

Genus Alces, C. H. Smith.

477. A. maChlis, Ogilby (F. Cuv., Mamm. Lithog. II, $98,99)$.

Syn. Cervus alces, Lin.

Alces palmatus, Gray.

(True Elk or Moose.)

HAB. Sub-arctic regions of Europe, Asia, and America.

$A$. Skull of Scandinavian male, 3 years old; and $B$. First horn of the young animal. $C$. The four feet, one fore-foot and one hind-foot skeletonized. Presented by the Christiania University, in 1846 (J. A. S. XV, Proc. XI, January 1846).

Sub-fam. CER VINAE.

Genus Tarandus, Pliny.

478. T. RaNGIFer (Buffon, $H$. $N$. XII, $t$. 10, 11,12 ; F. Cuv., Mamm. Lithog. II, 100.

Srn. Cervus rangifer, Ray.

C. tarandus, L.

C. coronatus, Geoffroy.

C. platyrhynchus, Vrolik.

(The Rein Deer or Caribou.)

$\mathrm{H}_{\mathrm{AB}}$. Arctic and sub-arctic regions of Europe, Asia, and America (Vide J. A. S. XXIX, 376, XXXI, 153).

$A$. Skull: and B. Stuffed head, with horns. $C$. The four feet, from the same Scandinavian individual. Presented by the Christiania University, in $1846^{*}$ (J.A.S. XV, Proc. X, January 1846).

\section{Genus Cervus, L. (as restricted.)}

* The stuffed skin, noticed in J. A. S. XVIII, 87, with that of an Algerian Lion received at the same time, gradually perished during successive rainy seasons, from having been prepared with deliquescent common salt, which I could not succeed in extracting sufficiently. 
(True Stags, or Elaphine group of Deer, pecum liar to temperate and cold climates in the northern hemisphere : foreign to India.*

479. C. Canadensis, Brisson (Wolf's Sketches, pl. ; J. A. S. X, $750, f s .5,6$ ).

Syn. C. elaphus canadensis, Erxleben.

C. wapiti, Leach.

C. strongyloceros, Schreber.

C. major, Ord.

C. occidentalis, C. H. Smith.

Hab. N. America.

(The 'Wapiti Stag'; miscalled 'Elk' by the Anglo-Americans. Vide J. A. S. X, 737.)

A. Frontlet with horns, purchased (1859); being that described in $J . A$. S. XXII, 592not those described in XXVIII, 298.

480. C. affinis, Hodgson (J. A. S. X, 722, pl. ); XX, $388)$.

(The 'Shou' of 'Tibet.)

Hab. Fastern Tibet; Mongolia (?): not India. (Vide 2 nd note to $J . A$. S. XXI, 34l.)

$A$. Frontlet with horns. Presented by W. Theobald, Esq., Junior, in 1850. B. Skull of adult male, with horns, taken from a skin presented by Dr. Campbell. C. Flat skin of male (before referred to). $D$. Ditto, of female. E. Ditto, of young. Presented by Dr. Campbell respectively in 1851 (J.A. S. XX, $341), 1853(\mathcal{J} . A$. S. XXII, 415), and 1854 (J. A. S. XXIII, 217).

481. C. Wallichir, Cuvier (F. Cuv., Mamm. Lithog. II, t. 103 ; J. A. S. XXIII, 135-series of horns).

* Dr. Gray remarks, that "the Stags of Canada and India have horns so sinilar that it is impossible to distinguish them by their horns ( $P$. $Z$. S. 1850, p. 222). There is no Indian Stag to which this remark applies; but the horns of young individuals of the Kashmirian C. WALLichi, and of the Tibetan C. AFFINIs, probably could not always be distinguished from those of C. CANADENSIS of similar age. Those of maximum growth are easily enough distinguishable. 
Syn. C. elaphus of Asia, Pallas, Zoogr. Ros. As. I, 216 (edit. 1831). Vide J. A. S. $\mathrm{XXX}, 187$.

C. pygargus apud Hardwicke.

C. caspianus et C. cashmiriensis, Falconer, vide P. Z. S. 1858 , p. 529.

C. nareyanus, Hodgson (juv.), (J. A. S. $\mathrm{XX}, 393$.)

\section{(Honglu of Kashmir ; Márál, Persia.)}

$\mathrm{H}_{\mathrm{AB}}$. Middle Asia, from the shores of the Euxine to the Altai, W. Tibét, and Kashmir; also the Amûr region, and island of Sankhalin (?).

$A$. B. Two frontlets with horns, purchased (1849-62). C. A pair, fixed on a stand. D. E. F. Loose horns. Presented by W. Theobald, Esq., Junior, 1854 (J. A. S. XXIII, 734). G. The small pair of horns from the animal originally described as C. WALLICHII, figured in J. A. S. 750, pl. f. 7 ; ${ }^{*}$ s. 8, 9, 10, also refer to this species (J. A. S. IX, $522)$.

482. C. Elaphus, L. (Sub-fossil horns figured in Nat. Hist. Review, $1860, p .61$; vide J. A. S. XXX, 185.)

SYN. C. vulgaris, L.

C. nobilis, Klein.

C. germanicus, Brisson.

(The Stag or 'Red Deer' of Europe.)

Hab. Europe.

A. Admirably stuffed head. Presented by H. R. H. the late Prince Consort, in 1861 (J. A.S. XXX, 185). B. Skull, with abnormal horns, a simple beam with brow-antler, and no additional branch. $\dagger C$. Skull from the skin of a young Stag. Presented by

* A remarkably fine pair, affixed to a stand, at present deposited in the Society's museum, belong to Col. C. S. Guthrie, of the Engineers, by whom they are reclaimable.

$\dagger$ I am aware that there is a technical name for this particular variety, recognised in the Scottish Highlands. 
Mr. C. W. Davison, in 1846 (J. A. S. XV, c.)* $D$. $E$. Two small frontlets with horns, from the same donor. F. A loose pair. Presented by C. Darwin, Esq., in 1857 (J. A. S. XXVI, 241). $F$. The four feet skeletonized.

483. C. taivanus, Blyth, J. A. S. XXIX, 90.

Svn. C. axis apud Cantor (?), Ann. M. N. H., IX (1842), note to p. 174.

Haв. Formosa.

$A$. Skull presented by R. Swinhoe, Esq., in 1860 (loc. cit.)

(Incertce Sedis.)

484. C. sikA, Schlegel, Fauna Japonica, t. 17 ; J. A. S. $\mathrm{XXX}, 91$.

Srn, Rusa japonica, Gray.

HaB. Japan.

$A$. B. Young males, stuffed. Presented by the Curator, in 1861.

Genus Dama, C. H. Smith.

485. D. vulgaris, Gesner (F. Cuv., Mamm. Lithog. I, 100, $101,102,103)$.

Srn. Cervus dama, $\mathrm{L}$.

C. platyceros, Ray.

(The Fallow Deer.)

Hab. Europe; W. Asia; N. Africa (Tunis?) Said to have been obtained fossil in British caves.

$A$. Skull, with splendid horns; taken from a skin prepared for stuffing. Presented by Mr. C. W. Davidson, in 1846 (J.A. S. XV, C). $E$. Stuffed head, with horns. Presented by the Curator. $F$. Frontlet and three odd horns. Presented by C. Darwin, Esq., in 1857. G. Stuffed doe, typically colored; and $E$. Fawn. Presented by Babu Rajendra Málliká, in 1849. $F$. Dark-colored doe. Presented by the same, in 1861 .

* This specimen should have been mounted; but it could not be managed from pressure of other work, and the skin became gradually too much injured to be set up : the same remark applies to $A$. of No. 485 . 
Sub-fam. RUSINAE.

(Peculiar to the inter-and juxta-tropical parts of Asia and its archipelago).

Genus Panolia, Gray.

486. P. Eldi ; Cervus Eldi, Guthrie (Calc. J. N. H. II, pl. XII, - the horns).

Sxn. Cervus frontalis, M. Clelland (ibid).

C. lyratus, Schinz.

C. dimorphe, Hodgson (with abnormal horns, as developed in captivity), $J . A$. S. XII, 897.

C. Smithii (?), Gray, P. Z. S. 1837, p. 45.

Panolia acuticornis et $P$. platyceros, Gray. (Sungnai or Singnai of Munnipúr; T'hâmine of Burmá.)

Hab. Pegu, northward to the valley of Munnipúr: Siam; and proximate portion of the Malayan peninsula (Keddá); Mergui. (The venison commonly brought to the provision-bazar at Rangoon, together with that of Sâmur, Hog Deer, and Muntjac. It is a highly gregarious species, resorting to openings in the forest, like the Indian Bára Singha (vide Eld, in Calc. J. N. H. II, 415).

A. B. Skulls, with fine horns, from Munnipúr. Presented by J. McClelland, Esq. (1844.)* C. Another skull (minus lower jaw); and $D$. Frontlet, purchased. $E$. Small frontlet. Presented by Col. C. S. Guthrie, in 1861, wholly unbranched $(J . A$. S. XXXI, 336). All from Munnipúr. F. G. H. Three skulls of bucks, one from Mergui (?). Presented by Major Berdmore, in $1856(J . A$. S. XXVII, 296); the others presented by Col. Phayre, from Pegu (1847). I. Frontlet, Pegu. Presented by Col. Phayre. J. Ditto (with small portion of skull attached), brought from Pinang. Presented by Capt. Harold

* "The generality of the Stags have from six to ten branches or snags; but I have killed very old ones, with no fewer than sixteen clearly defined branches." - Lieut. Eld. 
Lewis, in 1846. $K$. Skull of male in the second year, showing the horns at that age. Procured in the Rangoon bazar, and presented by Dr. Prichard of Rangoon, in 1861. L. M. Two heads of does, procured in the Rangoon bazar by the Curator, in 1861. N. O. Flat skins of does, from Mergui. Presented by Major Berdmore, in 1856 (J. A. S. XXVII,, 297 ).

Genus Rucervus, Hodgson.

487. R. Duvaucelit; Cervus Duvaucelii, Cuvier (Oss, Foss. IV, t. 29, fs. 6-8; F. Cuv., Mamm. Lithog. II, 104).

Syn. C. elaphoides (J. A. S. IV, 648), et $C$. bahraiya, Hodgson.

C. euryceros, Knowsley Menagerie.

(The 'Bára Singha').

HAB. Upper Bengal; valley of Nepâl; Asám; Nerbudda territory ; Eastern Sundárbans

$A$. Stuffed male, winter dress (J.A. S. XXVII, 81). B. Younger male, summer dress. $C$. Female, summer dress (J. A. S. XIX, 426). Carcasses presented by Babú Rajendra Málliká (1850 to 1858). D. Skull of adult male. E. F. Ditto. (wanting lower jaw). $G$. H. I. J. K. L. M. N. O. Series of frontlets. $P$. A lot of loose horns, most of them purchased by the Curator: one fine pair presented by R. W. G. Frith, Esq., in 1842 (J. A. S. XI, 1203); another presented by Genl. Hardwicke (As. Res. XIV, App. XXXIII).

Genus Rusa, C. H. Smith.

488. R. Aristotelis; Cervus Aristotelis, Cuvier (F. Cuv., Mamm. Lithog. I, 104, III, 93).

Syn. C. hippelaphus, C. equinus, et C. Leschenaultii, Cuvier.

C. niger, Blainville (indiv. var.).

C. jarai, Hodgson (Gl. Sc. III, 321 ; J. A. S. I, 66). 
'Great Axis' of Pennant. (The Samur; often miscalled ' Elk' by Anglo-Indian sportsmen; Schap in Burmese.) \&atz -

HAB. India generally, ascending to the highest forests of the Himálaya; Ceylon; IndoChinese region; Malayan peninsula ; "Sumatra; Borneo; Banka." (S. Müller).*

$A$. Stuffed male (J. A. S. XVI, 210). $B$. Stuffed female; and $\boldsymbol{C}$. Fawn. Presented by Bábu Rajendra Málliká (1846-51). D. Halfgrown specimen from the Society's old collection. $\dagger E$. Skeleton of male, from Barrackpore Park (1845). F. Skull of ditto. G. Another skull. $H$. Another (minus lower jaw). $I$. Frontlet. The last three from Asám. Presented by Col. Jenkins (1846). J. Skull (minus lower jaw), and $K . L$. Two frontlets, from Arakan. Presented by Col. Phayre (1847). $M$. Stuffed head from Himálaya. Presented by $J . J$. Athanass, Esq., in $1843(J$. A. S. XI. 449). $N$. Ditto, from Central India. Presented by Major Tickell (1846). $O$. Enormous pair of cast horns, from Coromandel coast, purchased (1848). P. Q. R. S. T. $U . V . W$. Frontlets. $X . Y . Z$. Deformed ditto. Also several loose horns. One abnormal pair (C. niger, Blainville, v. Rusa nipalensis, Hodgson). Presented by J. Pybus, Esq., in 1847 (J.A. S. XVI, 1276). Others presented by W. Masters, Esq. (J. A. S. XI, 96), and by O. W. Malet, Esq, C. S. (XV, 210); but the greater number purchased at various times. One horn, of the C. niger type, presented by Dr. Gordon, in 1843.

489. R. Tunjuc ; Cervus tunjuc, Vigors (S. Müller, Mamm. pl. ).

* The race seems rather smaller in Burmá, the Malayan peninsula, and Sumátra ; the $R$. equina, auct. : but it does not appear to me to be fairly separable. There are slight differences in almost every province. We are not well supplied with skulls; but one from Arakan has the nasal bones much more compressed than in Indian specimens. I have never seen really fine horns from the eastward of the Bay of Bengal.

$\dagger$ This, a Chevrotain, and a two-headed calf, were the only stuffed ruminants in the Society's museum when I took charge of it in $1841 .-E$. B. 
SYN. C. rusa, S. Müller.

Rusa hippelaphus (!) apud Gray, Ann. M. N. H. IX (1852), p. 422.*

Hab. Jáva; not Borneo nor Sumátra; (the $\boldsymbol{C}$. moluccensis, Quoy, v. C. rusa moluccensis, S. Müller, and C. rusa timoriensis of the Leyden museum, as cited by Dr. Gray, are barely separable). Introduced into the Mauritius. $\dagger$

$A$. Skull of male (minus lower jaw). $B$. Another (ditto), of a 'heaver' or castrated animal. $C$. $D$. Frontlets, with very fine horns, from Jáva. All presented by the Batavian Society in 1844. $E . F$. Two fine frontlets from Mauritius. Presented by Willis Earle, Esq. (not Capt. Clapperton), in 1842 (J. A. S. XI, 598). G. Skull (minus lower jaw), from the Mauritius. Presented by G. Hugon, Esq., in 1855 (J. A. S. XXIV, 480). $H$. I. Small frontlets, from Timor. Presented by the Curator, in 1858.

Genus Axis, C. H. Smith.

490. A. Maculatus, Gray, (Buffon, $H . N$. XI, t. 38, 39, F. Cuv., Mamm. Lithog. I, 98, 99).

Syn. Cervus axis, Erxleben.

A. major, medius, et minor, Hodgson.

C. nudipalpebra, Ogilby (melanoid variety). (Indian 'Spotted Deer' or Chittra).

HAB. India generally, with Ceylon: unknown east of the Bay of Bengal, unless as an imported animal.

$A$. Stuffed male. Presented by E. Higgin, Esq., in 1846. B. Another, castrated. Presented by P. Homfrey, Esq., in 1842 (J. A. S. $\mathrm{XI}, 1202) . \quad C$. Adult female (J.A.S. XI,

* The Hippelaphus of Aristotle is doubtless the Nilgai, as suggested by Mr. Ogilby ; rather than the Sâmur, as supposed by Cuvier : most undoubtedly it cannot refer to the Javanese Rusa. Neither can it be the CaPRA IEGAGRUS, as arguing by Capt. T. Hutton (J. A. S. XV, 148).

$\dagger$ In R. TUNJUC the inner prong of the terminal fork to the horn is much longer than the outer prong; being the reverse of what is seen in AxIs MACULATUS and others. 
1202). D. Smaller female. Presented by Bàbu Rajendra Málliká, in 1849. E. Flat skin, with horns, of melanoid buck. Presented by C. Chapman, Esq., c. S., in $1853(J . A$. S. XXII, 415). $F$. Skeleton of a young buck, from Society's old collection. $G$. Skull with very fine horns. $H$. $I$. Skulls of younger males. Presented by W. Masters, Esq. (J. A. S. XI, 96). $J$. Skull of adolescent female, from Society's old collection. K. L. M. N. O.P. Frontlets, some with particularly fine horns, and mostly purchased. Two heads presented by J. Athanass, Esq., in 1842 (J. A. S. XI, 599).

Genus Hyelaphus, Sundevall.

491. A. Porcinus; Cervus porcinus, Zimmerman (F. Cuv., Mamm. Lithog. III, 91, 92).

Syn. C. oryzeus, Kelaart, the Ceylon (and probably S. Malabar) race, or 'Paddy-field Deer' of Ceylon (J. A. S. XX, 174, XXIII, 217, XXVII, $\left.297^{*}\right)$.

C. dodur (?), Royle, Ill. Him. Bot.

(Hog Deer or Pára; Drai of the Burmans.)

HAB. Bengal ; Nipâl ; Asám ; Indo-Chinese countries (where very abundant); Deyra Doon; Sindh; S. Malabar (?) ; and Ceylon (a slight variety): but unknown in the peninsula of India generally.

$A$. Specimen from Ceylon. Presented (alive) by Dr. Kelaart, in 1852. B. Old buck, not in good condition. $C$. Younger buck, spoted. Presented by Bábu Rajendra Málliká, in 1857 (J.A. S. XXVI, 241). D. E. Doe, with spotted fawn. Presented by R. G. W. Frith, Esq., in 1843. F. G. Another doe, with fawn. Presented by Bábu Rajendra Málliká, in 1852. $H$. Skull of male. $I$. J. Other skulls

* Somewhat lighter in form, with the menilling more distinct in summer vesture, and the horns perhaps longer on the average, with the inner prong of the terminal fork branching at a less abrupt angle-all tending to approximate nearer to Axis MaColatus. 
(minus lower jaw.) K. L. M. N. O. P. Q. Frontlets. Two of them presented by W. Masters, Esq., in 1842 ( $J$. A. S. XI, 96). Others noticed in $J . A$. S. IX, 523 ; but most of the horns have been purchased at various times.

\section{Sub-fam MOSCHINAE.}

Genus Cervulus, Blainville (Muntjacus, Gray; Styloceros, C. H. Smith ; Prox, Ogilby).

492. C. vaginalis ; Cervus vaginalis, Boddaërt (Horsf., Zool. Res. in Java, pl. ).

Sxn. C. muntjac, Zimmerman.

C. aureus, C. H. Smith.

C. moschus, Desmarest.

C. ratwa, Hodgson.

C. melas, Ogilby.

C. albipes, Wagler.

(Muntjac or Kijang, Malay : Kákur or Barking Deer, Himálaya; Jungle Sheep of Madras sportsmen; Red Deer of those in Ceylon; Gee, Burmese.)

HAB. India generally, with Ceylon: IndoChinese region (where very abundant); $\mathrm{Ma}$ layan peninsula; Sumátra; Jáva; Borneo; Philippines (?).

$A$. Stuffed buck, dark-colored, from Nipâl. Presented by B. H. Hodgson, Esq., in 1844. B3. Another, of the usual chesnut coloring. Presented by P. Homfray, Esq. (1843.) C. Young. Presented by Bábu Rajendra Málliká, in 1852 (J. A. S. XXI, 358). D. $\boldsymbol{E}$. Male and female, not yet mounted, from the Tenasserim provinces. Presented by E. O'Reilly, Esq. (1847.) F. Skeleton of buck. Also presented (the carcass) by Bábu Rajendra Málliká. G. Skull of male. H. Another, imperfect. I. Frontlet, with unusually large horns. Presented by $W$. Masters, Esq., in 1842 (J. A. S. XI, 96). $J$. $K$. Other frontlets, from Arakan. Presented by Col. Phayre, in 1846. 
493. C. Reevesi ; Cervus Reevesi, Ogilby (P. Z. S. 1838, 105).

НАв. China.

A. Skull from Formosa (?). Presented by R. Swinhoe, Esq., in 1860 (J. A. S. XXIX, 93).

Genus Meminna, Gray.

494. M. IndicA, Gray (Buffon, H. N., Súpp., III, t. 15). Syn. Moschus meminna, Erxleben. Moschiola mimenoides, Hodgson.*

$\mathrm{H}_{A B}$. India generally (in suitable localities), with Ceylon. Unknown eastward of the Bay of Bengal.

$A$. Stuffed male. Presented by Dr. McCosh, in $1835(J . A$. S. IV, 587). B. Female. Presented by "a lady," in 1842 (J.A. S. XI, 96, 199). C. Young. Presented shortly afterwards by Mrs. Lindstedt (ibid, p. 87). $D$. Female ; and $E$. Young. Presented by$F$. Skeleton. Presented by the Right Hon'ble Lord Auckland, in 1837 ( $J$. A. S. XVI, 498).

Genus Tragulus, Brisson (nec Ogilby).

495. Tr. Javanicus, Pallas (F. Cuv., Mamm. Lithog. II, 97). Syn. Moschus indicus, Gmelin.

M. napu, F. Cuvier.

M. Stanleyanus, Gray (var.).

Tr. fuscatus, Blyth, J. A. S. XXVII, 278 (var.).

HAB. Malayan peninsula; Súmátra; Jáva; Borneo.

$A$. Specimen from Jáva (?). Presented by the Batavian Society in $1844(J . A . S$. described as $T r$. fuscatus, in $J . A$. S. XXVII,

* Dr. Gray separates the Indian and Malayan races; but I suspect incorrectly. The latter, he asserts, chiefly differs from the other in being darker-colored. (Ann. M. N. H. IX, 1852, p, 425.) The darkest specimen which I have seen is from Nepâl ; those of Burmá resembling the ordinary Indian animal. 
278, and probably the same as Meminua malaccensis, Gray, from "Singapore."* (Br. Mus. Catal., Mamm., p. 172), as it is obscurely palespotted on the sides. B. C. Male and female. Presented by the Máharája of Burdwán, in 1858, and described as $T r$. javanicus in $J . A$. S. XXVII, 277. D. Young male, from the Society's old collection, probably one of the two specimens of the "Java Musk Deer," presented by Mr. C. W. Smith, in 1836 (J. A. S. $\mathrm{V}, 438$, and referred to Moschus javanicus in X, 662). E. F. G. Three females of the same rufous variety (all with bright chesnutcolored necks), described as $T r$. javanicus, var. Stanleyanus, in J. A. S. XXVII, 277, and presented by the Máharája of Burdwán. $H$. Skull of female. I. Skull of male (with back part of head wanting. Origin of these uncertain.

496. Tr. Pelandoc; Moschus pelandoc (?), C. H. Smith, described in $I$. A. S. XXVII, 277.

SYN.? Chevrotain de Java of Buffon.

Tragulus affinis, Gray, Br. Mus. Catal.

HAB.

A. Specimen described loc, cit. Presented by the Máharája of Burdwán, in 1858.

497. Tr. KAnchil; Moschus kanchil, Raffles, vide J. A. S. XXVII, 276.

Srn. Moschus fulviventer, Gray (var.)

HAB. S. Tenasserim provinces; Malayan peninsula; Sumatra; Java; Borneo (?).

$A$. B. Males. $C$. Female, stuffed. $D$. Albino female, in bad condition. Presented by Dr. Coles, in 1841 (J. A. S. X, 840). E. F. G. H. Skulls taken out of badly prepared skins.

* Dr. Gray usually gives, as the habitat, the place from which a specimen has been received. Thus, he assigns Java (!) as a habitat for an example of Moschus Moschiferos.-Ibid. About as well refer to S. Africa as a habitat of the Rein Deer. 
Genus Moschus, L.

498. M. moschiferds, L. (Pennant's Quadrupeds, t. 12, f. 1). P.Z. S. 1858 , p. $528 ; G l$. Sc. III, 320 . SyN. M. saturatus, Hodgson.

$M$. leucogaster (?) et $M$. chrysogaster (?), Hodgson.

HAB. Himálaya; Tibet (that of Kashmir stated to be peculiar). Amûr territories; Singhalin; "Musk Ox" of Ravenstein's 'Russians on the Amûr,' p. 273 !

$A$. Stuffed male. Presented by G. T. Lushington, Esq., in 1849. B. Stuffed females. Presented by B. H. Hodgson, Esq., in 1846. C. Fine male. Presented by Capt. E. Smyth, in $1862(J . A$. S. XXX, 207). D. $E$. Skulls of male and female, perfect. $F$. Skull of male, with remarkably long tusks (but wanting lower jaw). Taken out of a badly prepared skin.

Sub-fam. CAPREOLINAE.

Genus Capreolus, C. H. Smith.

499. C. Europaus, Sundevall (F. Cuvier, Mamm. Lithog. II, 105, 106, 107).

Srn. Cervus capreolus, L.

Cap. caprea, Gray.

Hab. Europe (a larger race on banks of Danube, brought abundantly to the game-market of Vienna).

$A$. Stuffed male, from Scotland. Presented by Sir W. Jardine, Bt., in 1850 (J.A.S. ). B. C. Skulls, with remarkably fine horns. Purchased in 1860 . D.E.F. Frontlets. Presented by Mr. Davison, in 1844 (J. A. S. XV, XCIX).

Sub-fam —? (Ordinary American Deer.)

Genus Cariacus, Gray.

500. C. virginianus; Dama virginiana, Ray (F. Cuv., Mamm. Lithog. I, 95, 96, 97, 98). 
HAB. Atlantic side of the Rocky Mountains of $\mathrm{N}$. America.

$A$. Skull of young animal, taken from skin noticed in $J . A$. S. XVIII, 87, received from Mr. Barlett in 1849. B. Frontlet, with horns. Presented by C. Darwin, Esq., in 1857 ( $J . A$. S. XXVI, 241).

Genus Coassus, Gray.

501. C. nemorivagus; Cervus nemorivagus, F. Cuvier.

Syn. C. nemoralis, Desmarest,

C. simplicicornis, Illiger, $\}$ apud Gray.

Hab. Brazil.

$A$. Skin of female. Presented by Dr. Rüppell, in 1855 (J.A. S. XXIV, 212).

Fam. BOVID A.

Sub-fam. BOVINAE.

(A.-The Bisontine group.)

Genus Pö̈phagus, Gray.

502. P. GRUnniens; Bos grunniens, L. (skull figured, $J$. A. S. X., 470 ; vide P. Z. S. 1858,529 .)

Srn. Bos poëphagus, C. H. Smith.

(The Yak.)

HAB. Tibetan region.

A. Adult male, of the aboriginally wild race; stuffed. Presented by Captain E. Smyth, in 1862 (J.A. S. XXX, 207). B. Another stuffed male, of the small tame race of Sikhim (hybrid?). C. Skeleton of the same individual. The carcass presented by the Right Hon'ble Viscount Hardinge, in 1847. $D$. Skull, wanting nasal bones, of a small bull, taken from the skin. Presented by Dr. Pearson, in $1842(J . A$. S. XI, 444). E. Skull of hybrid. $F$. Frontlet and face of another hybrid. From Butan probably. Presented by Col. Jenkins and Capt. Snyth, in 1848-50. 


\section{(B.-The Taurine group.)}

Genus Zebus, Blyth.

(The humped cattle of tropical Asia and Africa.)

503. Z. Gibbosus; B. gibbosus, C. H. Smith.

SYN. B. indicus, L.

$\mathrm{H}_{\mathrm{AB}}$. Probably Africa aboriginally, and the domestic animal early introduced into Asia, vide J. A. S. XXIX, 285 : unknown in the aboriginally wild state; but constituting, at the present epoch, the ordinary domestic cattle of the inter-and juxta-tropical regions of the major continent; feral herds existing in many parts of India, in Ceylon, and it would seem also in parts of Africa.

$A$. B. Skulls of bull and cow of common Bengáli race; procured in Calcutta by the Curator, in 1859. C. Skeleton of Gyna, or dwarf bullock. Presented by the Curator in 1848. D. E. Skulls (minus lower jaw) of large up-country oxen. $F$. Bezoar, divided. Presented by R. Home, Esq., in 1816 (As. Res. XII, App. XXIII). $G$. The half of a bezoar, taken from the stomach of a Bengáli bull that had swallowed a native blanket (J. A. S. XXV, 445).

Genus Bos, L. (as restricted.)

504. B. TaUrus, L.

Srn. B. scoticus, Swainson. (The feral Chillingham cattle.)

HAb. Europe ; W. and N. Asia ; N. and S. Africa (mostly replaced by the humped cattle towards and within the tropics); vide J. A. S. XXIX, 287 ; Butan ; Socotra. Introduced into N. and S. America, Australia, Polynesia, \&c.

(N. B.-Various primæval races would appear to have contributed to the formation of the domestic Bos TAURUs; as the fossil and semi-fossil B. PRIMOgEniUs, perhaps $B$. TrOCHOCEROS, and certainly the B. FRONTOSUS and the B. LONGIFRONS of the European later deposits.) 
$A$. Skull of bull, sent as that of the Chillingham race, by Mr. Bartlett, in 1845 ( $J . A$. S. XV, Proc. C); but the horns slender and not typical. $B$. Frontlet of Caffre Ox, purchased in 1858.

\section{Genus Gavæuus, C. H. Smith.}

505. G. SondaICUs; Bos sondaicus, S. Müller (Mamm., $\mathrm{pl}$. ).

Sxn. B. bentinger, Temminck.

B. leucoprymnus, Quoy and Gaymard (the hybrid with ZeBus GIBBosus).

Tsoing of Burmá; Banteng of Java; Tambadau of Borneo. Both this and the next termed Sapi-utan (literally ' wild cow'), by the Malays of the peninsula.

HAB. Upper Pegu; Shan states; Mergui ; Keddá (N. E. portion of Malayan peninsula); Jáva; Báli ; Lombok; Borneo.

A. Splendid frontlet of bull, from Jáva. Presented by the Batavian Society, in 1844. $B$. Another frontlet of bull, believed to have been presented by H. R. H. Prince Henry of the Netherlands, in 1837 ( $J . A$. S. VI, 987).* C. D. Skulls of bulls, and $E$. Ditto (imperfect, and all wanting the lower jaw), from Upper Pegu. Presented by Col. Phayre, in 1849-50. $F$. Imperfect skin of cow : and G. Ditto of calf. From Mergui. Presented by Major Berdmore, in 1852-3 (J. A. S. XXI,

* "H. R. H. Prince Henry of Orange sent three heads of the wild bull of Java (Tandoe Banteng) for comparison with the Gaour of India. Dr. Evans pointed out remarkable specific differences in the forehead and position of the hor'ns of the two animals." (Loc. cit.) It is not stated that any were presented to the Society. A skull with horns of the Burmese Tsoing was presented to the Society by Mr. Maingy, in 1831 (Herbert's Gleanings in Science III, 61). In As. Res. XIII, App. XVIII, "horns of the hill cow of Arakan" (probably those of G. GAURUS) are recorded as having been presented by Lieut. J. Home ; in As. Res. XVI, App. XI, the "horn of a will cow, shot in the forests of the Wakroo district, on the route from Ye to Martaban," is mentioned to have been presented by Capt. F. Jenkins (also probably G. GAURUS): and in As. Res. XVII, 621, "the skull, horns, and hide of the Wild Cow of Tenasserim" are recorded as having been presented by W. B. Bayley, Esq. The only specimens of the G. sondarcus in the museum, when I took charge of it in 1841, were two frontlets of bulls, the smaller of which was since forwarded to the India-house museum.-E. $B$. 
443, XXII, ). H. Horn from the Arakan side of the mountains which separate that province from Pegu (or the valley of the Irawádi). Presented by Col. Phayre, in 1847. I. An interesting horn, converted into a powder-flask, illustrative of the 'Shan Bison' of Mr. Landers, presented in 1844. $J$. Another Peguan horn, like the last, at a stage of development which illustrates the meaning of the reported ' cylindrical-horned humpless cattle' of the Indo-Chinese region.

506. G. Gaurus; Bos gaurus, C. H. Smith (Madr. Jour. Lit. $\dot{S c}$. X (1839), p. 227 ; J. A. S. X, 470 , not good).

SYN. B. gour, Traill.

B. aculeatus, Wagler, Schinz.

B. asseel, Horsfield (female variety).

Bibos cavifrons, Hodgson.

(The Gaour, or ' Bison' of Anglo-Indian sportsmen; termed Gayál in Kuttak: Pyoung of Burmá.)

HAв. All suitable districts of India (and formerly Ceylon); Asámese hills, and Indo-Chinese region generally, extending south ward throughout the length of the Malayan peninsula, but not to the islands: inhabiting grassy uplands, interspersed with forest.

(N. B.-The Gaours of Burmá run very large, the bulls commonly attaining from 6 to $6 \frac{1}{2}$ feet, and even more (sometimes to 20 hands), at the summit of the elevated dorsal ridge; and the horns, of both sexes, are shorter and much thicker than in Indian Gaours.* A skull of a Tenasserim bull, with horns (minus lower jaw), weighs 34 lbs. Our largest Indian skull similarly weighs $30 \mathrm{lbs}$; and both are particularly fine. Some Burmese specimens, however, resemble the Indian race; and the same remark applies to all of the skulls which I have seen from the Malayan peninsula).

* Mr Hodgson's figure of a Nepâlese Gaour, in J. A. S. X, 470, approaches the Burmese type ; and the figure of the head of a Tenasserim Gaour, by Capt. (since Col.) Low, in Jour. Roy. As. Soc. III (1836), p. 50, is quite that of the Indian type. The Rhinoceros-head figured on the same plate with the other is obviously that of $R h$. sondaicus, and not of Rh. sumatranus (as suggested by Dr. Cantor, in J.A.S. XV, 613). 
A. Pair of massive horns of Burmese bull : and $B$. Right horn of cow. $C$. Another pair of bull-horns from Arakan. All presented by Col. Phayre, in 1847-61. D. Pair of cow-horns of the same race, from the Tipperá hills. Presented by the Rev. J. Barbe, in 1846, as those of a domesticated individual. $\boldsymbol{E}$. Horns of a small Indian bull, polished. Presented by G. Dowdeswell, Esq., in 1836 (As. Res. XII, App. XXII).

(The ordinary Indian race has the horns longer, less massive, and more attenuated.)

$F$. Stuffed bull, from Chaibasa. Presented by Major S. R. Tickell, in 1842 (J. A. S. XI, 588). G. Skin of cow, prepared for being mounted, from Umarkántak. Presented by Major R. Wroughton, in 1842 ( $J$. A. S. XI, 98, XII, 166). G. Skeleton of adult bull. $I$. Skeleton of adult cow, from Chota Nagpore. Presented by Major Ousley, in 1840 (J. A. S. IX, 865), and 1846 ( $J . A$. S. XXV, 415). Remarkably fine skull of bull, purchased in 1847. $K$. Another bull-skull, equally fine (but minus the corneous sheath to the horn-cores, and both wanting the lower jaw). Presented by Col. C. S. Guthrie, in 1862. $L$. Skull of a mature cow, from Asám. Presented by Col. Jenkins, in 1844.

507. G. Frontalis ; Bos frontalis, Lambert (Lin. Tr. VII, 57, pl. ?; skull figured in $J . A$. $S$. $\mathrm{X}, 470)$.

SYN. B. gavæus, Colebrooke.

B. sylhetanus, F. Cuvier (hybrid with common humped speçies).

(The Gayál, or Mit'hun.)

HAB. Hill regions east of the Brahmaputra river; the domestic race extending southward to the hills bordering on the Kaladyne river, which flows into Akyab harbour from the north; Chittagong hills; the wild race numerous in the Mishmi and other hill ranges bordering on Upper Asám; and northward the tame herds 
are seen grazing with domestic Yaks (As. Res. XVII, 387).

A. Adolescent bull, nearly full-grown, stuffed. Presented by R. W. G. Frith, Esq., in 1850 (J.A. S. XIX, 88). B. A bull-calf, about one-third grown, stuffed. Presented by the Curator, in 1857 (J.A.S. XVI, 210), $C$. Skeleton of not large adult domestic bull. Presented by the Curator, in 1849. D. Skull of 'wild bull,' minus lower jaw and corneous sheath to the horns. From Asám hills. Presented by Col. Jenkins, in 1848, as an example of the 'wild bull' of that region. $E$. Skull, and nearly perfect skeleton, of a young bull. Presented by Bábu Rajendra Málliká, in 1860. $\boldsymbol{F}$. Skull of a younger bull. $G$. Skull of a young hybrid, the produce of a Gayál bull (specimen $A$ ) with Bengali humped cow. Presented by R. W. G. Frith, Esq., in 1851.

C.-The Bubaline group.)

Genus Bubalus, C. H. Smith.

508. B. BUffeidus; Bos buffelus, Blumenbach (J.A. S. $\mathrm{X}, 470, \mathrm{f}$ ? ).

Syn. Bos bubalus, Brisson.

$B$. arni, Shaw (the wild animal).

(The Indian Buffalo: Urná, the wild race; Bhainsa, the tame.)

HAB. The Sub-Himálayan tarai region; and valleys of the Ganges and Brahmaputra; but elsewhere, for the most part (if not altogether), introduced, and feral in all suitable localities.

(a. The race with wide-spreading horns, chiefly inhabiting Asám. B. maccoceros, Hodgson, Calc. J. N. H.IV, 290.)

$A$. Skull of cow (minus lower jaw). Presented by Dr. F. Mouat, in $185^{\circ}(J . A . S$. XXVIII, 182).

(b. The ordinary wild race, with quadrant horns, curving (more or less evenly) from the base. B. speiroceros, Hodgson, ibid.) 
B. C. D. E. F. Skulls of bulls. G. H. Ditto of cows. All minus lower jaw. Three were presented by Dr. Wallich, in 1816 (As Res. XII, App. XXVI. Two from Asám. Presented by Major Brodie, in 1848 (J.A. S. XVII, 559); and one by Sir J. Barlow, Bart., in 1856 (J. A. S. X X V , 445). The remaining one by Lieut. R. C. Nuthall (as noticed in J. $A$. S. IX, 522). $J$. Skull of domestic cow, with lower jaw. From the Society's old collection.

509. B. CAFFER; Bos caffer, Sparrman.

HAB. S. Africa (the Abyssinian race apparently somewhat different).

A. Portion of skull, with horns, of young bull. Presented by Major W. S. Sherwill, in 1844.

\section{Sub-fam. TRAGELAPHINAE.*}

Genus Oreas, Desmarest (Boselaphus, C. H. Smith). 510. O. Canna ; Boselaphus canna, C. H. Smith (Wolf's Sketches, pl. ?; Harris's Wild Animals of $S$. Africa, t. 6).

Syn. Antilope oryx, Pallas (apud Gray).

$$
\text { (The ' Eland.') }
$$

$\mathrm{H}_{\mathrm{AB}}$. S. Africa (represented towards the equator by a race having the markings of the Koodoo -Oreas Derbianus, Gray).

A. Horn of a female. Presented by Major W. S. Sherwill, in 1843 (J.A. S. XII, 66).†

* With a bovine muzzle, and smooth unknotted horns, having in many species a spiral curvature. Females hornless (except in the genus OREAs) : teats four : the smaller species are monogamous : the greater number have ringed markings above the hoofs, certain white spots upon the face, and many have white streaks on the body, which attain their maximum of development in the TraGELAPHUS SCRIPTUS.

† "Two horns of the Antilope oreas of Linnæus, from Africa," are noticed as having been presented to the Society by Col. C. Mackenzie, in 1816 (As. Res. XII, App. XXV) ; also, "skins of the Eland; three bucks. Three seals." PHосж ?) By G. Siddons, Esq., in 1825 (As. Res. XV, App. XXXV). These I have never seen; nor are they noticed in Dr. Pearson's Catalogue, J. A. S. IX, 514 et seq. 
Genus Strepsiceros, C. H. Smith.

511. STr. KUdu, Gray (Harris's Wild Animals of S. Africa, t. 20).

Sxn. Antilope strepsiceros, Pallas.

A. tendal et A. chora, Rüppell (apud Gray).

(The Koodoo).

H.aB. S. Africa (that of Abyssinia stated to be one-third smaller).

$A$. B. Two fine pairs of horns. Presented by C. $C$. A single horn, noticed in $J . \dot{A}$. $S . \mathrm{IX}, 522$. (Vide note $\dagger$ to preceding page.)

Genus Portax, C. H. Smith, (F. Cuv., Mamm. Lithog. III, 100, 101).

512. P. tragocamelus ; Antilope tragocamelus, Pallas.

Syn. A. pictus, Pallas.

A. albipes, Erxleben.

A. leucopus, Zimmermam.

Portax risia, C. H. Smith.

Tragelaphus hippelaphus, Ogilby.

(The ' Nil-gai.')

Hab. India exclusively (not Ceylon).

$A$. Stuffed male (very fine) (J.A. S. XI, 1202). B. Stuffed female; from Barrackpore Park (J.A. S. XXIII, 211). C. Stuffed head of castrated male. Presented by —_..* $D$. Skeleton of male. $E$. $F$. Skulls of male and female. $\boldsymbol{E}$. Frontlet.

Genus Tetracerus, Leach.

513. T. QUADRICORNIS, Antilope quadricornis, Blainville (Hodgson, Calc. J. N. H. VIII, 88, plate ?; F. Cuv., Mamm. Lithog. III, 99).

Srn. A. chickara, Hardwicke.

A. striaticornis, Leach.

A. subulata (?) et

A. acuticornis, Blainville.

Cervus albipes, F. Cuvier.

* The castrated Nil-gai retains the coloring of the doe, and has small and slender horns. 
T. subquadricornutus, W. Elliot (var.)*

T. iodes, T. paccerois, Hodgson, Calc. J. N. H. VIII (1848), p. 90.

(The Chikara, Chousingha, or ' Fourhorned Antelope.')

$\mathrm{H}_{A B}$. India exclusively (not Ceylon).

A. B. C. D. E. F. G. Group of three males, a female, and three young, stuffed. $H$. Skeleton of male. I. J. K. L. Two skulls of males and two of females. $M$. $N$. Skulls of male and female, taken from skins sent as $T$. subquadricornutus. Presented by Walter Elliot, Esq., in 1845. Presented̆ by Bábu Rajendra Málliká and others. O. A particularly fine skull. Presented by J. B. Lawson, Esq. (J. $A . S . \mathrm{XXIV,} \mathrm{188.)}$

\section{Genus Calotragus, Sundevall (in part).}

514. C. melanotis; Antilope melanotis, Thunberg (Harris's Wild Animals of S. Africa, $t .16)$.

Syn. Antilope grisea, Cuvier.

A rubro-albescens, Desmoulins.

(The 'Grys-bok.')

HAB. S. Africa.

A. Stuffed male. Presented by E. L. Layard, Esq., in 1860 (J.A.S. XXIX, 100). $B$. Skull of male. Presented by Major W. S. Sherwill, in 1843 (not mentioned in the list given, in $J . A$. S. XII, 65).

515. C. TRagulus; Antilope tragulus, Forster (Harris's Wild Animals of $S$. Africa, $t .25, f .2$ ).

Syn. Antilope rupestris, $A$. pallida, et $A$. rufescens, C. H. Smith.

A. campestris, Thunberg.

* The development of the anterior pair of horns in the male of this animal is very irregular. In some they are wanting or barely indicated; in others small and blunt; and occasionally one is developed and not the other. In one skull, in the Society's collection, the anterior horns curve backward in a remarkable manner. I do not hesitate in resolving Mr. Hodgson's five species into one only. 
A. pediotragus, Afzelius.

A. fulvo-rubescens, Desmoulins. (The 'Stein-bok' of S. Africa.)

Hab. S. Africa.

A. Stuffed male. Presented by E. L. Layard, Esq., in 1860 (J. A. S. XXIX, 100).

Genus Oreotragus, Sundevall.

516. O. Saltatrix ; Antilope saltatrix, Boddaërt (Harris's Wild Animals of $S$. Africa, $t$. 24).

Syn. Antilope oreotragus, Forster.

(The ' Klip-springer.')

Hab. Mountains of E. and S. Africa.

$A$. Stuffed male. Presented by E. L. Layard, Esq., in 1860 (J. A. S. XXIX, 100). B. Stuffed head of female, from Somâli-land. Presented by Capt. Speke, in 1855 (J. A. S. XXIV, 298).

\section{Sub-fam. CEPHALOPHINAE**}

Genus Cephalophus, C. H. Smith.

517. C. GRimmia ; Capra et Moschus grimmia, L. (Harris's Wild Animals of S. Africa, t. 15.)

SYN. Antilope mergens, Blainville.

A. nictitans, Thunberg.

A. Burchellii, A. ptoox, et A.platous, C. H. Smith.

$$
\text { ('The 'Duiker-bok'). }
$$

Hab. S. Africa.

* A well marked group of mostly diminutive species peculiar to Africa ; much resembling the Muntjacs and Chevrotains of the family Cervids, of S. E. Asia and its archipelago ; as also the American Rodent Agoutis in general appearance, if not likewise the smaller fossil pachyderms assigned to LopHIODON : all have the same Pig-like form, with short slender limbs; and the Philantombahs resemble the Muntjacs and Chevrotains in their long extensile tongue. 'They have short horns, mostly directed backwards, and semi-ringed at base; and between the horns is a tuft of lengthened hair. The Cremalopuus symvicultrix is a giant among them, as the Capybara is among the Cavies. The females of this group are hornless, and have four teats. 
$A$. Stuffed male. Presented by E. L. Layard, Esq., in 1860 (J.A. S. XXIX, 100).

518. C. natalensis; Antilope natalensis, A. Smith ( $S$. African Zoology, Mamm. t. 32).

HAB. Natal (S. E. Africa).

$A$. Stuffed male. Presented by M. Alfred Malherbe of Metz, in 1859 (J. A. S. XVIII, $80)$.

519. C. monticola ; Antilope monticola, Thunberg (Harris's Wild Amimals of S. Africa, t. 26.)

Syn. G. A. perpusilla et $A$. carulea, C. H. Smith. A. pygmæea, Lichtenstein.

(The 'Blau-bok.')

Hab. S. Africa.

$A$. Male. Presented by E. L. Layard, Esq., in $1860(J . A . S$. XXIX, 186).

Genus Neotragus, C. H. Smith.

520. N. Saltiana; Antilope saltiana, Blainville (Rüppell Atlas, t. ?).

Syn. N. madoka, C. H. Smith,

Antilope Hemprichianus, Ehrenberg.

A. grimmia et $A$. Hemprichi, Rüppell.

Hab. Abyssinia; Somáli-land.

A. Stuffed male. B. C. D. Stuffed heads of two males and a female. From Somâli-land. Presented by Capt. Speke, in 1855 (J.A.S. XXIV, 297).

\section{Sub-fam. ADENOTINAE.*}

Genus Eleotragus, Gray.

521. E. CAPREOLUS; Antilope capreolus, Thunberg(Harris's Wild Animals of S. Africa, $t .25, f .1)$.

* Another strongly-marked group, peculiar to Africa, with bovine muzzle, and semi-ringed horns, which curve forward at the tips or throughout. The larger species have a coarse pelage, and approximate the Sâmur group of Deer: the small are very elegant animals, with a soft coat ; these latter are monggamous, if not the rest; and the females of all are hornless, and have four teats. 
Srn. Antilope villosa, Burchell.

A. lanata, Desmoulins.

(The Rhee-bok or 'Reh-bok.')

$A$. Frontlet of male. Presented by Major W. S. Sherwill, in 1843 (J. A. S. XII, 65). $B$. stuffed kid. Presented by E. L. Layard. Esq., in 1860 (J. A. S. XXIX, 100).

Sub-fam ANTILOFINAE.*

(A.-The Oryx group.)

Genus Aigoceros, C. H. Smith.

522. Aig. Equinus, C. H. Smith (Harris's Wild Animals of S. Africa, $t . \quad)$.

Syn. Antilope glauca, Forster.

A. osanne, Geoffroy.

A. barbata, C. H. Smith.

A. Truteri, Fischer.

Capra athiopia, Schinz.

A. leucophrea, Pallas, var.? (now extinct, vide P.Z. S. 1850, p. 133).

(The 'Roan' or 'Equine Antelopé'.)

Hab. S. Africa.

A. Fine frontlet of male. Presented by-.

Genus Oryx, Blainville.

523. O. Gazella; Capra gazella, L. (Harris' Wild Animals of S. Africa, t. 9).

Srn. O. capensis, Ogilby. Antilope oryx et $A$. bezoartica, Pallas. $A$. recticornis, Erxleben.

Hab. S. Africa (The Cape Oryx, or ' Gems-bok.' $A$. Fine frontlet of male. Presented by$B$. Single horn of female. Presented by G. Cathcart, Esq., in 1844.

524. O. LEUCORYX; Antilope leucoryx, Pallas (Wolf's Sketches, pl. ; F. Cuv. Mamm. Lithog. I, 106).

* Desert Animals, with more or less ovine muzzle, and ringed horns, generally present (though smaller) in the female sex. Proper to Asia and Africa; the Jaiga alone extending to range to the confines of Europe. Teats generally two, 
Srn. Antilope ensicornis, Ehrenberg, A. algazella, Ruppell,

A. gazella, Pallas,

A. bezoarticus, Erxleben,

A. eleotragus, Schreber,

(The white Oryx.)

$\mathrm{H}_{A B}$. N. and W. Africa : Nubia: Sennaer; Senegal.

$A$. Fine skull of female, with horns; noticed in $J . A$. S. IX, 519.

(B.-The Bubalis group.)

Genus Boselaphus, Ray (apud Gray; Acronotus, C. H. Smith).

525. B. CanMa; Antilope caama, Cuvier (Harris's Wild Animals of S. Africa, t. 7).

Srv Antilope bubalis apud Lichtenstein.

$A$. senegalensis, Cuvier.

(The 'Harte-beest.')

HaB. S. Africa.

$A$. Frontlet with horns of male. Presented by Major W. S. Sherwill, in 1843 (J.A.S., XII, 65). B. Horn of female. Presented by

Genus Damalis, C. H, Smith.

526. D. PyGarga; Antilope pygarga, Pallas (Harris's Wild Animals of S. Africa, t. 17).

Syv. Antilope dorcas, Pallas (apud Gray).

HAB. S. Africa.

(The Bonte-boc.)

$A$. Pair of horns. Presented by Major W. S. Sherwill, in 1843 (J. $A$. S. XII, 65). $B$. Three loose horns.

\section{( $C$. The Antelopes and Gazelles.)}

* "A skull of the Cape Antilope" is recorded in As. Res. XII, App. as having been presented to the Society by R. Home, Esq. ; and the "horns and part of the skull" of the present species in $J . A . S . I X, 520$. Neither of them were in the Society's Museum when I took charge of it in 1841. 
Genus APyCeros, Sundevall.

527. AE. melampus Antilope melampus, Lichtenstein (Harris's Wild Animals of S. Africa, t. 15).

HAB. S. Africa.

$$
\text { (The 'Pakah.') }
$$

$A$. Frontlet, with smallish horns; purchased in 1861 .

Genus Antilope, L. (as restricted.)

528. A. Bezonrtica, Aldrovand (Hardwicke, Ill. Ind."Zool;

F. Cuv. Mamm. Lithng. III, 102, 103).

Syn. A. cervicapra, Pallas.

A. bilineata, Temminck (apud Gray).

(The Indian Antelope, or Sasin.)

HAB. Plains of India.

A. B. C. Stuffed males. D. Ditto, castrated.* $E$. Stuffed female. $F$. $G$. Kids. $H$. Skeleton. I. J. K. Stuffed heads of male, one with abnormal horn. $L$. Frontlet. Presented by G. T. Lushington, Esq. (J. A.S. IV, 56 ; W. Masters, Esq., J. J. Athanass, Esq., in 1842 (J. A. S. XI, 597); Bábu Rajendra Málliká and others.

Genus Antidorcas, Sundevall.

529. A. EUChORE; Antilope euchore, Forster(Harris's Wild Animals of S. Africa, t. 3).

Srn. Antilope saltatrix, Link.

A. marsupialis, Zimmerman.

A. pygarga, Blumenbach.

$A$. dorsata et $A$. saliens, Lacépede.

$A$. ibex, Afzelius.

(The 'Spring-bok.')

Hab. S. Africa.

A. Small pair of horns (bad). B. C. Two odd horns, one of them presented by Major W. S. Sherwill, in 1843 (J.A. S. XII, 65).

* The horns of the castrated male gyre round, like those of Ovis Ammon. Horned females are exceedingly rare ; and the horns of these resemble those of the castrated male, except in being more slender. 
Genus Gazella, C. H. Smith.

(a. With horned females.)

530. G. DoRCaS; Capra dorcas, L.

Syn. Antilope dorcas et A. gazella, Pallas.

$A$. arabica, Hemprich and Ehrenberg.

Gazella cora, G. kevella, et G. corinna, C. H. Smith.

(The Arabian Gazelle.)

$\mathrm{H}_{A B}$. Arabia; N. Africa.

A. B. C. D. Stuffed males. E. $\boldsymbol{F} . \boldsymbol{G}$. Stuffed females. $H$. Kid. $I$. Skeleton. $J$. Stuffed head of male. $K$. Skull of ditto. L. M. Skulls of females. $N$. Frontlet of male. Presented by the Máharaja of Burdwán, Bábu Rajendra Málliká, and others.*

531. G. Spekei, Blyth (heads described in $J$. A. S. XXIV 297).

Hab. Somâli-land.

A. B. Stuffed heads of male and female. Presented by Capt. Speke, in 1855.

(b. With hornless females.)

532. G. subgutrurosa; Antilope subgutturosa, Guldenstadt.

Srn. C'afra ahu, Kæmpfer.

A dorcas, var persica, Rüppell.

(The Persian Gazelle.)

Hab. Afghánistan; Persia; Armenia; Tartary. A. B. Stuffed males. C. Stuffed female. Presented by Bábu Rajendra Málliká. $D$. Skull of male, from Kandahar. Presented by Capt. T. Hutton, in 1846. $E$. Frontlet, from Kandahar. Presented by Major H. B. Lumsden, in 1859 (J.A.S. XXVIII, 411).

Genus Tragors, Hodgson.

* An animal marked Gazella Christii, Gray, in the London United Service Museum, appeared to me to be G. subGutTurosa. It was labelled from Sindh, but might have been brought thither from beyond the Passes. 
533. Tr. BennetriI ; Antilope Bennettii, Sykes.

Srn. A. Christii, Gray (apud Gray).*

A. hazenna, Is. Geoffroy.

A dorcas, var., E. Sundevall.

(The Indian Gazelle, or 'Goat Antelope,' often termed 'Ravine Deer' by sportsmen).

HAB. India.

A. Skull of male from Pind Dádun Khan. Presented by W. Theobold, Esq., in 1853. (J. A. S. XXII, 583).

Genus Procapra, Hodgson.

534. Pr. Picticaudata, Hodgson (J. A. S. XV, 173, 324, t. ).

(The Goa, or Tibetan Gazelle.)

Hab. Tibet.

$A$. B. Stuffed males. C. Stuffed female. D. E. Frontlet of males. Presented by Col. Jenkins (1846).

Genus Kemas, Ogilby.

535. K. Hodgsonli ; Antilope Hodgsonii, Abel (Gl. Sc. I, 144, II, $349 ; J . A$. S. I, 59, III, 134).

Srn. Antilope kemas, C. H. Smith.

A. chiru, Lesson.

(The Tchiru, or Tibetan Antelope.)

$\mathrm{H}_{\mathrm{AB}}$. Tibet ("common all over the open plains of Central and Eastern Tibet. Hodgson").

A. Stuffed male (not good). Presented by G. T. Lushington, Esq., C. S. B. Stuffed head of male. $C$. Skull of ditto. $D$. Another skull of ditto (minus lower jaw). Presented by

Sub-fam. CAPRIN $A$.

(A. Capricorns.)

Genus Capricornis, Ogilby.

* After elaborate study of these specimens, I have been obliged to bring all of them together, and suspect that the whole of the animals had been brought to India from Aden and Muskat. 
536. C. Bubalina ; Antilope bubalina et A. thar, Hodgson, vide Gl. Sc. III, 120, 324 ; J. A. S. IV, 489.

(The 'Surrów'.)

Haв. Himálaya.

$$
\text { (The 'Surrów') }
$$

A. Stuffed head.

537. C. RUBIDA, Blyth.*

Hab. Arakan Hills.

$A$. Stuffed head. B. Flat skin (imperfect), with horns. $C$. Skin of kid. From Arakan. Presented by Col. Phayre.

538. C. sumatrensis; Antilope sumatrensis, Shaw (F. Cuv. Mamm. Lithog. II, 109).

Srv. Antilope interscapularis, Lichtenstein.

(The Kambeng utan.)

HAB. Tenasserim hills; Maláyan peninsula; Sumátra.

$A$. Skull, marked from Sumátra. Society's old collection. B. C. Two skulls from Tenasserim provinces. $D$. A third (minus nasals, intermaxillaries, and lower jaw), also from Tenasserim. Presented by Major Berdmore in $1861 E . F$. Two flat skins (imperfect), Tenasserim. Presented by Major Berdmore.

(B. The 'Takin.')

Genus Budorcas, Hodgson.

539. B. TAXicolor, Hodgson, J. A. S. 1850 , p. 65 . t. 1. (The 'Takin.')

Hab. Mishmi hills, at the head of the valley of Asám.

$A$. Stuffed female. B. Stuffed head of male. $C$. Frontlet of male. $D$. Frontlet of female. $E$. Portion of the skull, with horns, of a young male. Presented by Col. Jenkins.

(b. The Goats and kindred genera.)

Genus Namorhedus, C. H. Smith, Discr. J. A. S. IV, 488.

* Of a red-brown color, with black dorsal list ; the hair shorter than of the others. 
540. N. Goral; Antilope goral, Hardwicke (F. Cuv. Mamm. Lithog. III, 107).

Syv. A. Duvaucelei, C. H. Smith.

(The 'Goral.')

HAB. Himálaya.

A. B. Stuffed specimens. C. D. Stuffed heads. E. Skull. $F$. G. Frontlets. Presented by B. H. Hodgson, Esq.

Remark._The Asámese (or Butan?) race is bright rufous. H. A. Skin. Presented by Col. Jenkins.

Genus Hemitragus, Hodgson.

541. H. Jemlaicus ; Capra jemlaica, C. H. Smith (Wolf's Sketches, pl. ).

Srn. Capra jharal et C. quadrimammis, Hodgson,* J. A. S. IV, 491, $710, \mathrm{~V}, 254$.

(The ' Tehr.')

HAB. Himalaya.

A. Stuffed male. Presented by Capt. Smythe. B. Stuffed female. Presented by - ? C. D. Stuffed heads of male. $E$. Ditto of female. $F$. G. Skulls of male and female. Presented by Mr. Hodgson, Mr. Frith, and others.

542. H. HYlOCRIUS; Kemas hylocrius, Ogilby.

Syn. Capra warryato, Gray.

(The so-called 'Nilgiri Ibex')

Haв. Nilgiris ; S. Malabar; (qu. 'wild Sheep' of Madura province?)

$A$. B. Skulls of male and female. $C$. Stuffed head of female. $D$. Another skull (imperfect). Presented by Dr. T. C. Jerdon, the Rev. H. Baker, Junr. (J. A. S. XXVIII, 382), by and Dr. L. C. Stewart.

\section{Genus Capra, L.}

* No. 542 has two teats only : individuals of the domestic Goat occur rarely with four developed mamma. No. 541 has normally four teats. 
543. C. Sibirica, Meyer (Schinz, Monogr.)

Syn. C. Pallasii, Schinz.

C. sakeen, Blyth.

C. himalayana, ibid., apud Schinz.

$\mathrm{H}_{\mathrm{AB}}$. Mountains about Kashmir; middle and $\mathrm{N}$. Asia (found on the Tibetan slopes of the Himálaya, and in the other high mountains of Tibet, north of I Lassa and Digurchu, as well as towards the frontier of China. Hodgson).

A. B. C. D. Four frontlets of males, with horns. $\boldsymbol{E}$. Skull (minus lower jaw). Presented by

544. C. exgagrus, Gmelin.

(Hutton, Calc. Journ. N. H. II, pl. XIX).

Srn. C. caucasica apud Gray.

Hab. W., Middle, and N. Asia: Caucasus and Taurus.

A. Skull, with horns, from Afghánistân.

From Sir A. Burnes's collection.

545. C. megaceros, Hutton (Calc. J. N. H. II, 535, pl. $\mathrm{XX}$, the horns).

SrN. C. Falconeri, Hugel.

('The ' Markhor.')

HAB. Afghanistân; Sulimani range ; mountains of Kashmir.

$A$. Skull (wanting the corneous sheath of one horn. B. C. Two odd horns. Presented by Sir A. Burnes. D. Frontlet. Presented by W. Theobald, Esq., Junior.

546. C. HIRCUS, L.

Hab. Domesticated nearly throughout the world.

$A$. Large Sikhim breed, with very long hair, stuffed. Presented by - B. C. Small Sikhim breed. Presented by Bábu Rajendra Málliká. $D$. Another stuffed Goat from the Society's old collection, $E$. Stuffed head of Jámnipára 
(same as Syrian) Goat, with very long ears. $\boldsymbol{F}$. Stuffed head of female British Goat. Presented by Bábu Rajendra Málliká, in 1861. G. Skeleton of Jámnipára Goat. H. I. Skulls (without horn-sheaths).

\section{Genus Ovis, L.}

547. O. ammon ; Capra ammon, L.

Syn. Aigoceros argali, Pallas.

O. Hodgsonii, Blyth.

O. ammonoides, Hodgson.

(The Hyan of Tibetans).*

Hab. Tibet; N. Asia.

A. Stuffed male. Presented by G. T. Lushington, Esq., $B$ another. Presented by Capt. Smyth, in 1862. C. D. Two skulls of males. Presented by G. F. Lushington, Esq. E. Skull of young male (imperfect). $F$. Pair of loose horns of female.

548. O. crcloceros, Hutton (Cal. Jiurn. N. H. II, pl XIX, Wolf's Sketches, pl. , P. Z. S. 1838, $526)$.

Syn. O. Vignei, Blyth (in part).

(The Ooriá.)

O. montana apud Cunningham (Ladák).

HAB. Afghánistân; Alpine Panjáb (represented in the Nineveh sculptures).

$A$. Stuffed female, and $B$. Lamb. From Punjab Salt Ranges, Presented by W. Theobald, Esq., Junr., in 1853 (J.A. S.XXII, 583). $C$. Young male. Presented by Bábu Rajendra Málliká, in 1850 (J.A. S. XIX, 561). $D$. E. F. Skulls of males. G. H. I. Skulls of females. $J$. Frontlet. Two male skulls from Sir A. Burnes's collection (J.A. S. IX, 1139). Presented by W. Theobald, Esq.

* A pair of horns of C. Polir, Blyth, are stated in Dr. Horsfield's Catalogue of the India-house Museum, to have been " presented by the Asiatic Society of Bengal." 'This is a mistake. They were doubtless presented by the Royal Asiatic Society of London, the Museum of which contained the noble frontlet originally described by me. $-E$. $B$. 
549. O. Nahura, Hodgson (J. A. S. IV, 492),

$\mathrm{H}_{\mathrm{A} B}$, Himálaya.

$A, B$. Stuffed male and female. Presented by Captain Smyth, in 1862. C. Another stuffed female presented in $1860 . D$. Skin of lamb. E. Stuffed head of male. F. G. H. Skulls of males $\quad I$. J. Frontlets of smaller males. $K . L$. Ditto of females. Presented by

550. O. ARIES, L.

(The domestic Sheep).

A. B. Skull and stuffed head of polycerate sheep. Presented by Bábu Rajendra Málliká (XXII, 214, XXVIII 506). C. Stuffed head of the 'Barwal' Sheep of Nipal, $J A$. $S$. XVI, 1010, pl. . Presented by B. H. Hodgson, Esq, in 1844. D. E. F. G. Heads of various breeds. $H$. Skeleton. I. J. Skulls wanting horn-cores.

Aplodontia.

Order EDENTATA.

Fam. MYRMECOPHAGID $\not E$.

Genus Mrrmecophaga, L.

551. M. Jubata, L. (Buffon X, t. 29).

SYN. M. tridactyla, L.

M. sciurea, Pallas.

Hab. Tropical S. America.

$A$. Stuffed specimen received from $\mathrm{Mr}$. Bartlett (1849), J. A. S.

Genus Orycteropus, Geoffroy.

552. O. CAPENSIS.

Syn. Myrmecophaga capensis, L.

M. afra, Pallas.

O. senegalensis, Lisson. Aard-vark (or ' Earth-hog').

$\mathrm{H}_{\mathrm{AB}}$. Africa, 
A. Stuffed specimen, from S. Africa. Presented by E. L. Layard, Esq. (1859) J. A. S. XXIX, 100.

Genus MaNis, L.

553. M. Pentadactyla, L.

Syn. $M$. macroura, Desm. (nec Erxleben).

M. brachyura, Erxleben.

M. brevicaudata, Teidemann.

M. laticaudata, Illiger.

$M$. inaurita, Hodgson.

Pangolinus typus et $P$. brachyurus, Lesson.

Has. India proper; Ceylon.

A. Stuffed specimen. Presented by Major Tickell, vide J. A. S. XI, 453. B. Another. Presented by Mr. W. Masters (J.A. S. XI, 96). C. Young. Presented by Mr. Frith. $J$. A. S. XVI, 1273. D. Skeleton of adult. Presented by Mr. Frith (1848). E. Skull from Ceylon. Presented by Dr. E. F. Kelaart (1852). $F$. Another.

554. M. aUrita, Hodgson, J. A. S. V. 234.

Syn. M. javanica, apud nos, passim, and also of Mr. A. Adams in P. Z, S. 1859, p. 132.

Hab. Himálayas; China.

$A$. Fine adult specimen from Sikhim. Presented by Dr. T. C. Jerdon in 1862. $B$. simaller Himálayan specimen, with tail imperfect. Presented by W. Theobald, Esq., Junr., in 1853. C. Flat skin from China. Presented by R. Swinhoe, Esq., in 1860. $D$. Skull taken from a small specimen. (N.B. Most conspicuously distinct from the preceling species.)

555. M. Javanica, Desmarest.

Syn. M. leucura, nobis, J. A. S. XI, 454, XVI, 1273.

Hab. Burmese region; Malayan peninsula and islands. 
A. Large specimen. Presented by $\mathrm{t}^{\mathrm{l}} \mathrm{e}$ Batavian Society in 1844. B. A smaller specimen; and $C$. Small young from Arakan.* Presented by the present Col. Phayre in $1844-6$.

556. M. Leptura, Blyth, J. A. S. XI, 454, XVI, 1273. $\mathrm{HAB}$ ?

$A$. Specimen from the Society's old collection. $B$. Skull taken from the same.

Sub-class II. IMPLACENTALIA.

Order I. MARSUPIATA.

Fam. DASYURID $A$.

Genus Thylacinus, Temminck.

557. Th. cynocephalus (Tr. Lin. Soc. IX, 174, pl. 19). Syn. Didelphis cynocephalus, Harris.

Th. Harrisii, Temminck.

Th. striatus (Warlow, J. A. S. II, 97).

' Native Tiger,' 'Hyæna,' 'Zebra Wolf, and Dog-headed Opossum,' of colonists.

Hab. Tasmania.

$A$. Imperfect skin. $\dagger \quad B$. Skull of male Presented by Dr. J. Henderson (1835): vide $J$. A. S. IV, 572 , and fig. $C$. Skull of female; vide J. A. S. IX, 524.

Genus Sarcophilus, F. Cuvier.

558. S. unsinus (Tr. Lin. Soc. IX, 176, pl. 19, f. 2).

Syn. Didelphis ursina, Harris.

' Native Devil' of colonists.

FiAb. Tasmania.

$A$. Stuffed specimen (bad) ; $\ddagger$ and $B$. Skull. Presented by the Curator (1842).

* An example (with whitish terminal third of tail) was obtained by me while in Mergui.

$\uparrow$ Remains of the specimen described in the 'Gleanings in Science,' III, 175 (1831).

$\ddagger$ This stuffed specimen was picked up in "one of the streets of Calcutta. Another is mentioned in $J . A . S . I V, 475$, which is no longer extant (unless the identical example by a strange accident.) 
Genus Dasyurus, Geoffroy.

559. D. maculatus (Nat. Libr., Marsupialia; pl. III).

Syn. Viverra maculata, Shaw.

D. macrourus, Geoffroy.

' Native Cat' of colonists.

HAB. Tasmania.

A. Stuffed specimen. Presented by Lieut. Abbott (18).

560. D. viverrinus, (Shaw's 'Zoology,' X, pt. 2, pl. 3).

Syn. Didelphis viverrina, Shaw.

Das. viverrinus, black var.

Das. Maugei, brown var. $\}$ Geoffroy.

'Native Cat' of colonists.

Has. N. S. Wales and Tasmania.

$A$. Stuffed specimen (black), and $B$. Ditto (brown), purchased (1846). C. D. Ditto (brown), from Mr. Bartlett (I849). E. Skull taken from $C$.

Genus Phascogale, Temminck.

561. Pir. Flavipes, Waterhouse.

Syn. Ph. rufigaster et Antechinus favipes, Gray. Ant. Stuarti (?), Mackay.

Hab. N. S. Wales and S. Australia.

A. Stuffed specimen, from the Sydney Institution (1845).

Genus Podabrus, Gould.

562. P. Crassicaudatus, Gould (Mamm. Austr. I, pl. 5,

Waterhouse, Mamm. I, pl. 15, f. 2).

HAB. W. and S. Australia.

$A$. B. Specimens. Presented by the Melbourne Institution (1862).

Fam. PERAMELID E.

Genus Perameles, Geoffroy. 
563. P. obesula, (Waterhouse, Mamm. I, pl. 15, f. 1).

Syn. Didelphys obesula, Shaw.

$P$. fusciventer et $P$. affinis, Gray.

Hab. N.S. Wales; S. and W. Australia; Tasmania. $A$. B. Specimens. Presented by the Melbourne Institution (1862).

564. P. Gunnit, Gray (Natr. Libr., Marsup., pl. 15).

HaB. Tasmania.

A. B. Specimens. Presented by the Melbourne Institution (1862).

Fam. PHALANGISTID AE.

Genus Piinlangista, Cuvier.

565. Pr. vulpina (F. Cuv. et Geoff., Mammiféres, pl. 45).

Syn. Didelphys vulpina et D. lemurina, Shaw.

Ph. melanura et Ph. felina, Wagler.

Ph. fiiliginosa, Ogillby.

Ph, Cuvieri, Gray.

' Opossum' of Colonists.

Hab. E. W. and N. Australia; Tasmania.

A. Stuffed specimen from N. S. Wales; Mr. Bartlett (1849). B. Ditto, from Port Philip; presented by Mr. Benson (1846). C. Ditto from Tasmania (purchased). D. $E$. other, and $F$. another (sooty-coloured) : from Tasmania. Presented by C. J. T. Lloyd, Esq. (1860). G. Skull taken from $C$.

Genus Petaurus, Shaw.

566. P. taguanoides, Desmarest (Nat. Libr. Marsup. pl. 2).

Syn. Petaurista Peronii, Desmarest.

'Large Flying Squirrel' of culunists.

Genus Belideus, Waterhouse.

567. B. Australis, Shaw (Nat. Misc. pl. 30).

Srn. Didelphys petaurus et D. macroura (?), Shaw. Petaurista flaviventer, Desmarest. 
'Long-tailed Squirrel' of colonists.

HaB. N. S. Wales.

A. Specimen (in bad order).

568. B. sciureus (Gould's Mamm. Austr., pt. I, pl. 4.)

Syn. Didelphis sciurea, Shaw.

'Sugar Squirrel' of colonists.

Hab. N. S. Wales.

$A$. Stuffed specimen. Presented by Mrs. Major Turnbull, in 1860, (J.A.S.XXIX, 70).

Genus Acrobata, Desmarest.

569. ACR. Pygmea (Nat. Libr. Marsup., pl. 30).

Srn. Didelphis pygmoea, Shaw.

'Flying Mouse' of colonists.

Haв. N. S. Wales.

$A$. Specimen. Presented by the Sydney Institution (1846).

Fam. MACROPODID AE.

Genus Macropus, Shaw.

570. M. Giganteus, (Gould's Monograph, pl. I).

Srn. Yerbua gigantea, Zimmerman.

Didelphis gigantea, Schreber.

M. major, Shaw.

$M$. ocydromus et $M$. melanops, Gould.

Kangarus labiatus, Desmarest.

Halmaturus griseofuscus, Goldfuss.

'Boomer' and 'Forester' of the colonists.

HAB. E. S. and W. Australia; Tasmania.

A. B. Stuffed specimens of adults. Pre. sented by the Melbourne Institution in 1862, as $M$. major and $M$. ocydromus. C. Ditto, young male, from the Barrackpore Menagérie, (1847). D. Skeleton of last. E. Skull of a larger individual. Presented by Dr. Wallich, (As. Res. XII, App. XXVII). F. Young in spirit. 
571, M. FRenatus, Gould (Monogr. pt. I, pl. 13).

Hab. Brezi and similar hills, central Australia.

$A$. B. Stuffed specimens. Presented by the Melbourne Institution (1862).

Genus Lagorchestes, Gould.

572. L. GYmnotis, Blyth, J. A. S. XXVII, 276.

Hab. ?

A. Specimen. Presented by the Máharája of Burdwán in 1858.

Genus Halmaturus, F. Cuvier.

573. H. RUFicollis, (Gould's Monograph, pt. II. pl. 2).

SxN. Kangarus ruficollis et rufo-griseus, Desmarest.

Halmaturus elegaus, (Lambert), Gray.

H. griseo-rufus, Goldfuss.

H. leptonyx (?), Wagner.

HaB. N. S. Wales.

$A$. Stuffed specimen. Presented by the Sydney Institution in 1841.

574. H. BennetTil (Gould's Monogr., pt. I, pl. 7).

Syn. Macropus Bennettii, et

M. ruficollis, var. Bennettii, Waterhouse.

H. fruticus, Ogilby.

H. ualabatus apud Gray, M. N. H., n. s., I, 583 (1837).

'Brush Kangaroo' of colonists

HAb. Tasmania.

$A$. Stuffed male. Presented by the Curator in 1847. $B$. Another. Presented by the President, A. Grote, Esq., in 1862. C. D. Skeletons of male and female. $E$. Skull of a younger specimen. $C$. and $E$. are from the Society's old collection; $C$. having been presented by H. S. Prinsep, Esq., in 1839.

575. H. unlabatus, (Zool. de la Coquille, tom. I, pl. 7). Syn. Kangarus ualabatus, Lesson and Garnot. K. Brunii apud Desmarest. 
Halmaturus Lessonii, Gray.

H. nemoralis, Wagner.

Haв. N. S. Wales.

$A$. Stuffed specimen. Presented by the Sydney Institution, in 184 . B. Skull, from Society's old collection.

576. H. Derbianus, Gray (Gould's Monograph, pt. I, pl. 11) Syn. H. Houtmani, Gould.

HAB. W. and S. W. Australia.

$A$. Stuffed male. $B$. Stuffed female. $C$. Younger female. Presented by Bábu Rajendra Málliká in 1847-8.

577. H. Penicillatus, Gray (Gould's Monogr. pt. II, pl. 8).

Srn. Heteropus albogularis (?), Jourdan.

Hab. N. S. Wales.

$A$. Stuffed specimen. Presented by the Máharája of Burdwán in 1858.

578. H Billardieri (Gould's Monograph, pt. I, pl. ).

Syn. Kangarus Billardieri, Desmarest.

Macropus rufiventer, Ogilby.

Halmaturus ( Thylogale) Tasmanii, Gray.

$H$. brachytarsus, Wagler.

$\mathrm{H}_{\mathrm{AB}}$. Tasmania.

$A$. Skeleton. B. Skin of head and neck from a carcass. Presented by Bábu Rajendra Málliká in 1848 (J. A. S. XVII, 560).

Genus Hypsiprymus, Illiger.

579. H. RUfescens (Gould, Monogr. pt. II, ).

Syn. Bettongia rufescens, Gray.

H. melanotis, Gould.

HaB. N. S. Wales.

$A$. B. Specimens. Presented by the Sydney Institution in 1862.

Genus Betrongia, Gray. 
580. B. GraII ; Hypsiprymnus Graii, Gould.

SYN. H. Lesueuri (?), Quoy and Gaymard.

HAB. W. and S. Australia.

A. B. Specimens. Presented by the Melbourne Institution in 1862.

581. B. Penicillata, Gray (Waterhouse, Mamm. I, pl. 9).

Syn. Hypsipetes setosus, Waterhouse.

Bettongia Ogilbyi, Gould, Waterhouse.

Hab. N. S. Wales.

A. Specimen. Presented by the Máharája of Burdwán in 1858.

582. B. Cuniculus, Ogilby (Gould's Monogr. pt. II, pl. 14).

Syn. Bettongia setosa, Gray.

HAb. Tasmania.

$A$. Skull. Presented by W. Cracroft, Esq.

Fam. PHASCOLOMYIDA.

Genus Phascolomys, Geoffroy.

583. Рн. wombat, Peron and Lesueur (F. Cuv., Mamm.

Lithog.

Srn. Ph. fossor, Sevanstian or

Ph. wombatus, Leach.

Ph. fusca, Desmarest.

Ph. bassii Lesson.

Ph. ursinus, Gray.

'Native Badger' of colonists.

Hab. N. S. Wales.

A. Specimen. Presented by C. J. T.

Lloyd $B$. Skull, imperfect, taken from $A$.

Order II MONOTREMATA.

Genus Ornithorhynchus, Blumenbach.

584. O. anatinus, (Leach Z. M. t. 111). 
SyN. Platypus anatinus, Shaw.

O. paradoxus, Blumenbach.

O. fuscus et rufus, Peron.

O. brevirostris, Ogilby.

O. crispus et lavis, McGillivray.

'Water Mole' of colonists.

Hab. N. S. Wales; Tasmania.

A. B. Stuffed specimens. Presented by H. T. Prinsep in 1842. $C$. Specimen in spirit. Presented by

Genus Echidna, Cuvier.

585. E. ACrobata (Leach Z. M. t. 90).

SyN. Myrmecophaga aculeata, Shaw.

Ornithorhynchus hystrix, Home.

Ech. hystrix, Cuvier.

E. longiaculeata, Tiedmann.

Tachyglossus aculeatatus, (Illiger), Schreber

'Native Porcupine' or 'Porcupine Ant-eater' of colonists.

Hab. E. and W. Australia (the Tasmanian species distinct).

A. B. C. Stuffed specimens: one mentioned in $J . A$. S. II, 98; another presented by Mr. N. Vicary in 1838 (J.A. S. VII, 465); the third obtained in 1862 . 



\section{A P PENDIX.}

No. 4.-Mr. A. Wallace obtained adult males of Simia Morio (vide Zoologist, p. 5113, Ann. M. N. II. xvij (1856), p. 473.

No. 6. a.-H. agilis, F. Cuvier. Two specimens presented by the Máharája of Burdwan.

No. 9 \& 11.-A newly born hybrid, from a Cape Baboon by a Pig-tailed Monkey, was presented to the Museum by Bábu Rajendra Múlliká in 1862.

No. 13 \& 14.-I now consider these to be identical, varieties merely, such as are noticed by Raffles of his S. carpolegus. The species inhabits so far as the rocky hills bordering Akyab Harbour to the south. I doubt, however, whether Macacus arctoides of Lesson, is rightly placed here as a synonym.

No. $17 \& 18$,-Are scarcely more than varieties of the same Monkey, with or without a slight top-knot on the vertex.

No. 52.-Doubtless Pt. nicobaricus, Scherzer.

No. 58. a.-Add Cynopterus nicobaricus, (?) Scherzer. From Andamans, Col. Tytler.

No. 95.-Vesp. formosa, Hodgson, is evidently identical with my Tickelli, Vide Fig. P. Z. S. 1858, pl. xv.

No. 175.-I don't think this name can stand. It is Macrocelis. 


\section{LIST OF DESIDERATA.}

Pachydermata

Ruminantia ...

(RHinoceros indicus. Skeletons and stuffed

Rh. sumatranus. $\quad$ specimens.

Sus. andamanensis. Stuffed specimens.

Sus. (Porcula) Salvanica, Hodgson. Skeleton and stuffed specimens.

Lippopotamus. Skeleton.

Camelus bactrianus. Skulls of both sexes matured.

C. Dromedarius. Skull of mature male, and series of candal vertebræ; also skull of young animal exemplifying the first dentition.

Cervus wallichir, Duvaucel. Stag of Kashmir.

C. Affinis, Hodgson. Stag of E. Tibet.

C. (Panolia) eldi, Guthrie, Pegu, Munnipúr, \&c.

Bos sondaicus. Skeleton of bull; skull of cow; and skins fit to be set up.

B. Gaurus. Skulls of the Burmese type, with short thick horns.

Ovis Polir, Blyth. P. Z. S. 1840. Pass of Pamir, Shá of Tibet.

O. Vignei, Blyth. Vide P.Z. S. 1840.

O. crcloceros, Hutton. Ibid. Uriá of Panjâb, W.

Persia, and Armenia.

O. gmelini, Blyth. P.Z. S. 1840.

Capra siberica, Pallas. Ibex of Kashmir, \&c.

C. cgagrus, Gmelin. Wild Goat of Salimani range, \&c.

C. Megaceros, Hutton. Markhôr.

Hemitragus hrlocrius; Kémas hylocrius, Ogilby.

Nilgiris; S. Malabar. Nilgiri Ibex (so called).

Capricornis. All the species or races. (Surrów,

Eymoo and Kambeng utan.)

Marsupialia $\ldots . .\left\{\begin{array}{l}\text { Thylacinus harrisit. } \\ \text { Dasyurus ursinus. } \\ \text { Peramelis lagotis. } \\ \text { Mrrmecohins fasciatus. } \\ \text { Phascolarctos koala. }\end{array}\right\} \begin{aligned} & \text { Skins and skeletons; } \\ & \text { also skeleton of Phasco- } \\ & \text { lomys, Wombat, and } \\ & \text { ditto of Ornithorynchus } \\ & \text { and of Echidna. }\end{aligned}$ 


\section{N D EX.}

A.

$\begin{array}{lllll}\text { Acrobata } & \ldots & \ldots & \ldots & 183\end{array}$

$\begin{array}{llll}\text { Acr. pygmæa } & \ldots & \ldots & i b .\end{array}$

ADENOTIN 2

REPCEROS ...

A. melampus

Aigoceros ...

Aig. equinus ...

Airurus

A. fulgens $\ldots$

Alactaga $\cdots$

A. bactriana ...

Alces

A. machlis

ALCIN $\mathbb{E}$

Antidorcas ...

A. euchore ...

A. bezoartica

ANTILOPINAE

Arctictis

A. binturong...

ARCTOMYDINE

Arctomys

A. bobac

Arctonyx $\ldots . .$.

A. collaris $\quad \ldots \quad \ldots$

- taxoides ... ...

Arvicola $\quad \ldots \quad \ldots$

A. amphibia ...

- arvalis ...

- glareola ...

- nivalis ...

- roylei ...

Astromydes...

A. cristatus $\ldots$

Atherura ...

Ath. fasciculata

Auchenia ...

Auch. glama...

AxIs

A. maculatus

\begin{tabular}{|c|c|c|c|c|c|c|}
\hline \multicolumn{2}{|c|}{ Page. } & \multicolumn{3}{|c|}{$B$. } & \multicolumn{2}{|c|}{ Page. } \\
\hline$\cdots$ & 183 & BABYRUSSA & $\ldots$ & ... & ... & 142 \\
\hline$\ldots$ & $i b$. & B. Alfurus & $\cdots$ & $\ldots$ & & $i b$. \\
\hline$\ldots$ & 168 & BALENA & $\ldots$ & $\ldots$ & $\ldots$ & 93 \\
\hline$\ldots$ & 171 & B. australis & & $\ldots$ & $\ldots$ & 94 \\
\hline ... & $i b$. & - mysticetu & & $\ldots$ & $\ldots$ & 93 \\
\hline$\ldots$ & 169 & BALENID & & $\ldots$ & $\ldots$ & $i b$. \\
\hline$\ldots$ & $i b$. & BALANOPTE & & $\ldots$ & $\ldots$ & $i b$. \\
\hline$\ldots$ & 74 & B. indica & & $\ldots$ & $\ldots$ & $i b$. \\
\hline$\cdots$ & $i b$. & BARBASTELL & & $\ldots$ & $\cdots$ & 36 \\
\hline$\ldots$ & 110 & B. communi & & $\ldots$ & $\ldots$ & $i b$. \\
\hline$\ldots$ & $i b$. & BATHYER & iGID & E... & $\ldots$ & 126 \\
\hline$\ldots$ & 145 & BATHYERGUS & s... & $\ldots$ & $\ldots$ & $i b$. \\
\hline$\ldots$ & $i b$. & B. maritimu & s... & $\ldots$ & $\ldots$ & $i b$. \\
\hline$\ldots$ & $i b$. & Belideus & $\ldots$ & $\ldots$ & $\ldots$ & 182 \\
\hline ... & 171 & B. australis & $\ldots$ & $\ldots$ & $\ldots$ & $i b$. \\
\hline ... & $i b$. & - sciureus & $\ldots$ & $\ldots$ & $\ldots$ & 183 \\
\hline ... & $i b$. & BeLuga & $\cdots$ & $\ldots$ & $\ldots$ & 90 \\
\hline$\ldots$ & $i b$. & B. catodon & $\ldots$ & $\ldots$ & $\ldots$ & $i b$. \\
\hline ... & 169 & BETTONGIA & $\ldots$ & $\ldots$ & $\ldots$ & 185 \\
\hline$\cdots$ & 49 & B. cuniculus & 5 & $\ldots$ & $\ldots$ & 186 \\
\hline$\cdots$ & 26. & - graii & & $\cdots$ & $\cdots$ & $i b$. \\
\hline … & $i b$. & Bos & & $\cdots$ & $\cdots$ & $\begin{array}{r}2 b . \\
159\end{array}$ \\
\hline$\ldots$ & $i b$. & B. taurus & $\ldots$ & $\ldots$ & $\ldots$ & $i b$. \\
\hline$\ldots$ & 71 & BosELAPHUS & $\ldots$ & $\ldots$ & $\ldots$ & 170 \\
\hline ... & $i b$. & B. caama & $\ldots$ & $\ldots$ & $\ldots$ & $i b$. \\
\hline$\cdots$ & $i b$. & BOVIDE & $\ldots$ & $\ldots$ & $\ldots$ & 158 \\
\hline$\ldots$ & 124 & Bubalus & $\ldots$ & $\ldots$ & $\ldots$ & 163 \\
\hline$\cdots$ & $2 b$. & B. buffelus & $\ldots$ & ... & ... & $i b$. \\
\hline ... & 125 & - caffer & $\ldots$ & $\ldots$ & $\ldots$ & 164 \\
\hline$\ldots$ & 124 & Budorcas & $\cdots$ & $\cdots$ & 年 & 174 \\
\hline$\ldots$ & 124 & B. taxicolor & $\ldots$ & $\ldots$ & ... & ib. \\
\hline
\end{tabular}

C.

Chelogenys ... 128

$\begin{array}{lllll}\text { C. paca } & \ldots & \ldots & \ldots & i b .\end{array}$

$\begin{array}{llll}\text { Callocephalus } & \ldots & \ldots & 77\end{array}$

$\begin{array}{llll}\text { C. annellatus... } & \ldots & \ldots & 78\end{array}$

— grœnlandicus $\quad \ldots \quad \ldots \quad$...

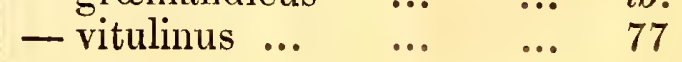


Calotragus ...

C. melanotis ...

- tragulus

CAMELID

Camelopardalis

C. giraffa

Camelus $\quad .$.

C. dromedarius

CANIID AE ...

Canis

C. alpinus (?)

- aureus

- familiaris ...

- laniger ..

- lupus

- melanotus...

- pallipes ...

- variegatus

CAPra

C. mararus …

- hircus

- megaceros

- sibirica

CAPREOLI $\dddot{N}$ E

Capreolus ...

C. europaus ...

Capricornis ...

C. bubalina ...

- rubida

- sumatrensis

CAPRINZE ..

Cariacus $\ldots$

C. virginianus

Castor

C. europæus ...

Catopon

C. macrocephalus

CATODONTIN

Cavia

C. australis ...

- cobaya

CAVID IE

CEPIDA

CEPHALOPḦIN $\ddot{\mathrm{F}}$

Cephalophus

C. grimmia

- monticola...

- natalensis ...

Cercolisptes

C. caudivolvulus

Cercopithecus

C. faunus

- engythithia

\section{Page.}

.. 166

$\ldots \quad i b$.

... 143

... 144

... ib.

... 143

... ib.

... 37

... 38

... $i b$.

0

40

38

39

...

ib.

$i b$.

ib.

40

175

176

ib.

$i b$.

$i b$.

157

$i b$.

$i b$.

173

174

$i b$.

$i b$.

173

157

... ib.

... 123

... ib.

... 93

... $i b$.

... 93

... 129

... $i b$.

... ib.

... ib.

... 16

... 167

... ib.

... $i b$.

... 168

... ib,

‥ 74

... ib.

... 10

... ib. DAMA

ib. D. vulgaris ...

C. monoides ...

- ruber

- sabrus

CERVIDA ...

CERVIN Æ ...

Cervulus

C. reevesi ...

- vaginalis ...

Cervus

C. affinis ...

- canadensis

- elaphus ...

- sika

- taivanus $\cdots$

- wallichii ...

Cheiromeles

Ch. torquatus

Crrrysochloris

C. damarensis

- holosericea

Chrysothrix

Chr. sciureus...

Conssus ...

C. nemorivagus

Colops

C. frithii

COLOBID $\ddot{\mathrm{E}}$

Corsina

C. alpinus

- vulgaris

Crossopus

Cr. fodiens

Cuon

C. rutilans

Crnailurus ...

C. jubatus ...

Crnalopex ...

C. bengalensis

- ferrilatus ...

Crnocephalus

C. porcarius ...

Cynogate ...

C. bennettii ...

Crnopterus ...

C. marginatus

Cystophora ...

C. cristata
Puge.

10

CYSTOPIÖRIN $\ddot{\mathbb{E}}$

D. $\begin{array}{rrr}\ldots & \ldots & 10 \\ \ldots & \ldots & 11 \\ \ldots & \ldots & 10 \\ \ldots & \ldots & 145 \\ \ldots & \ldots & i b .\end{array}$

$\begin{array}{rrr}\ldots & \ldots & 10 \\ \ldots & \ldots & 11 \\ \ldots & \ldots & 10 \\ \ldots & \ldots & 145 \\ \ldots & \ldots & i b .\end{array}$

$\begin{array}{rrr}\ldots & \ldots & i b . \\ \ldots & \ldots & 154\end{array}$

$\begin{array}{lll}\ldots & \ldots & 155\end{array}$

... $\quad \ldots \quad 154$

... $\quad \ldots \quad 145$

... $\quad \ldots \quad 146$

.. $\quad \ldots \quad i b$.

$\begin{array}{lll}\ldots & \ldots & 147\end{array}$

... $\quad \ldots \quad 148$

... $\quad \ldots \quad i b$.

... $\quad$.. 146

... $\quad$... 29

... $\quad . . \quad i b$.

... $\quad \ldots \quad 87$

... $\quad \ldots \quad 88$

... $\quad \ldots \quad 87$

... $\quad \ldots \quad 16$

... $\quad \ldots \quad i b$

$\begin{array}{lll}\ldots & \ldots & \\ \ldots & & \end{array}$

$\ldots \quad \ldots \quad$... $\quad$...

$\begin{array}{lll}\ldots & \ldots & 27\end{array}$

.. $\quad \ldots \quad i b$.

... $\quad$... 11

... $\quad \ldots 86$

... $\quad . . \quad i b$.

.. $\quad \ldots \quad i b$.

... $\quad \ldots \quad 87$

$\ldots \quad \ldots \quad i b$.

.. $\quad \ldots \quad 37$

$\ldots \quad \ldots \quad i b$.

$\begin{array}{lll}\ldots & \ldots & 65\end{array}$

.. $\quad \ldots \quad i b$.

... $\quad \ldots \quad 41$

... $\quad . . \quad i b$.

$\ldots \quad \ldots \quad i b$.

.. $\quad \ldots 6$

... $\quad \ldots \quad i b$

... $\quad \ldots \quad 49$

.. $i b$.

$\begin{array}{lll}\cdots & \ldots & 22\end{array}$

... $\quad \ldots \quad i b$.

$\begin{array}{lll}\ldots & \ldots & i b . \\ \ldots & \ldots & 79\end{array}$

ib.

$i b$. 
Malis

Dipus

D. mauritanicus

DASYURID $\mathbb{E}$

Dasyurus ...

D. maculatus

- viverrinus

DELPHINID压

Delphinus ...

D. eurynome...

- frithii

_ obscurus ...

- perniger ...

DIPODID स

Dipus

D. mauritanicus

E.

Echidna

E. acrobata $\ldots . \quad \ldots$

Euephas $\quad \ldots \quad \ldots$

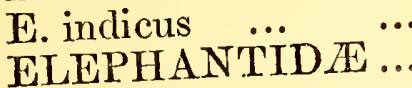

Eleotragus ... ...

E. capreolus ...

Equus

Eq. asinus ...

- caballus ...

- hemionus

- onager ...

- zebra ...

Erinaceus ...

E. Collaris ...

- megalotis ...

- micropus ...

- vulgaris ...

ERINACEID

F.

Fiber

F. zibethicus...

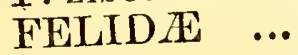

FeuIs

F. bengalensis

- cafia

- caracal

- catus

- celidogaster

- charltoni ...

- charlton
170

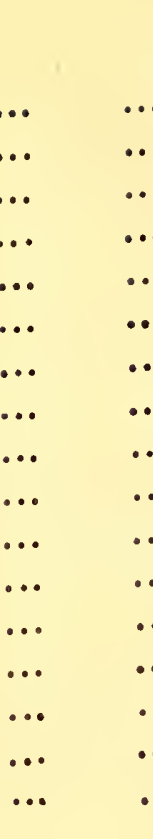

$i b$.

110

$i b$.

180

181

$i b$.

ib.

88

90

$i b$.

91

90

91

.. 110

ib.

$i b$.

187

... ib.

... 133

... 134

... 133

... 168

.. 168

$\begin{array}{rr}\cdots & i b . \\ \cdots & 135\end{array}$

... 1 ib.

...

....

ib.

136

… 135

... 136

80

$i b$.

$i b$.

$i b$.

$i b$.

ib.

123

$i b$.

53

$i b$.

60

63

64

62

61

59

63
F. isabellina ... $\quad \ldots \quad \ldots \quad \ldots 64$

$\begin{array}{lllll}\text { - leo } & \ldots & \ldots & \ldots & 53\end{array}$

$\begin{array}{lllll}-\operatorname{lynx} & \ldots & \ldots & \ldots & 64\end{array}$

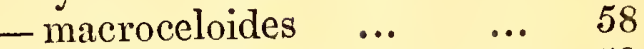

$\begin{array}{llll}\text { - marmorata } & \ldots & \ldots & 59\end{array}$

$\begin{array}{lllll}\text { - ornata } & \ldots & \ldots & \ldots & 63\end{array}$

$\begin{array}{lllll}- \text { pardus } & \ldots & \ldots & \ldots & 55\end{array}$

$\begin{array}{llll}\text { - planiceps ... } & \ldots & \ldots & 62\end{array}$

$\begin{array}{lllll}- \text { rufra } & \ldots & \ldots & \ldots & 65\end{array}$

$\begin{array}{lllll}\text { - } \operatorname{serval} & \ldots & \ldots & \ldots & 62\end{array}$

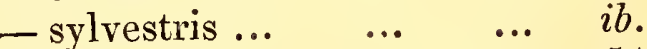

$\begin{array}{lllll}\text { 一 tigris } & \ldots & \ldots & \ldots & 54\end{array}$

$\begin{array}{llllll}\text { 一 uncia } & \ldots & \ldots & \ldots & 58\end{array}$

G.

GALEOPITHECID $\mathbb{E} \quad \ldots \quad 19$

Galeoptthecus $\quad \ldots \quad \ldots \quad i b$,

$\begin{array}{lllll}\text { G. volans } & \ldots & \ldots & \ldots & i b .\end{array}$

$\begin{array}{lllll}\text { Gaverus } & \ldots & \ldots & \ldots & 160\end{array}$

$\begin{array}{lllll}\text { G. gaturus } & \ldots & \ldots & \ldots & 161\end{array}$

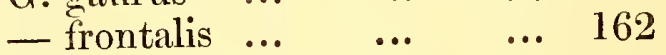

$\begin{array}{llll}\text { - sondaicus... } & \ldots & \ldots & 160\end{array}$

$\begin{array}{lllll}\text { GAZELLA } & \ldots & \ldots & \ldots & 172\end{array}$

$\begin{array}{lllll}\text { G. doreas } & \ldots & \ldots & \ldots & i b .\end{array}$

$\begin{array}{lllll}\text { - spekei } & \ldots & \ldots & \ldots & \ldots\end{array}$

$\begin{array}{llll}\text { - subguttrurosa } & \ldots & \ldots & i b .\end{array}$

$\begin{array}{lllll}\text { Genetta } & \ldots & \ldots & \ldots & 46\end{array}$

$\begin{array}{lllll}\text { G. afra } & \ldots & \ldots & \ldots & i b .\end{array}$

$\begin{array}{lllll}- \text { tigrina } & \ldots & \ldots & \ldots & i b .\end{array}$

Georhychus ... $\quad \ldots \quad \ldots \quad \ldots 127$

$\begin{array}{lllll}\text { G. capensis } & \ldots & \ldots & \ldots & i b .\end{array}$

- cæcutiens... $\quad \ldots . \quad \ldots \quad i b$.

$\begin{array}{lllll}\text { Gerbillud } & \ldots & \ldots & \ldots & 110\end{array}$

$\begin{array}{lllll}\text { G. indicus } & \ldots & \ldots & \ldots & i b .\end{array}$

$\begin{array}{lllll}\text { - afer } & \ldots & \ldots & \ldots & 111\end{array}$

Grobicephanus $\quad \ldots \quad$..

Gl. deductor ... $\quad \ldots \quad \ldots \quad i b$.

$\begin{array}{lllll}- \text { in dicus } & \ldots & \ldots & \ldots & i b .\end{array}$

$\begin{array}{lllll}\text { Golunda } & \ldots & \ldots & \ldots & 121\end{array}$

$\begin{array}{lllll}\text { G. ellioti } & \ldots & \ldots & \ldots & i b .\end{array}$

$\begin{array}{lllll}\text { Gumo } & \ldots & \ldots & \ldots & 65\end{array}$

$\begin{array}{lllll}\text { G. luscus } & \ldots & \ldots & \ldots & i b \text {. }\end{array}$

Grmnura $\quad \ldots \quad$. .

G. RAFFLESII... $\quad \ldots \quad \ldots \quad i b$.

$\mathrm{H}$.

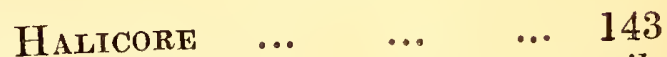

$\begin{array}{lllll}\text { HI. australis } & \ldots & \ldots & \ldots & i b .\end{array}$

$\begin{array}{lllll}\text { - dugong } & \ldots & \ldots & \ldots & \ldots\end{array}$

HALICORID $\mathbb{E}$ \& $\quad \ldots \quad \ldots \quad i b$.

Halmaturus $\quad \cdots \quad \ldots l 184$ 
H. bennettii ...

Page.
184

- billardieri..

- derbianus...

- penicillatus

- ruficolles ...

- ualabatus ...

Hapalomys ...

$\mathrm{H}$. langicaudatus

Hapalotis ...

H. apicalis ...

- mitchellii ...

Hemictis

H. nipalenus ...

Hemigalea ...

H. derbiana ...

Hemitragus ..

H. hylocrius ...

— jemlaicus ...

Herpestes ...

H. brachyurus

- caffer

- fuscus ...

- fulvescens

- griseu

- ichnuemon

- malaccensis

- nipalensis ...

- paludosus...

$\ldots$

... 184

\begin{tabular}{ccc|lllll}
$\ldots$ & $\ldots$ & 185 & Hylonates & $\ldots$ & $\ldots$ & $\ldots$ & 4 \\
$\ldots$ & $\ldots$ & $i b$. & - agilis & $\ldots$ & $\ldots$ & $\ldots$ & 5
\end{tabular}

H. porcinus ...

Page.

$\begin{array}{lll} & \ldots & \\ & \ldots & 153\end{array}$

$\ldots \quad \ldots \quad i b$.

... $\quad$... 184

... $\quad \ldots \quad i b$.

... $\quad$... 112

.. $\quad \ldots \quad i b$.

... $\quad \ldots \quad 111$

... $\quad \cdots \quad i b$.

... $\quad$... $i b$.

... $\quad$... 70

... $\quad$... ib.

... $\quad$... 46

... $\quad \ldots \quad 46$

$\begin{array}{rrr}\ldots & \ldots & 46 \\ \ldots & \ldots & 175\end{array}$

$\begin{array}{ccc}\ldots & \ldots & 175 \\ \ldots & \ldots & i b .\end{array}$

$\begin{array}{lll}\cdots & \cdots & i b .\end{array}$

$\begin{array}{lll}\cdots & \cdots & i b .\end{array}$

,. $\quad \cdots \quad 50$

... $\quad \ldots \quad 52$

$\cdots \quad \cdots \quad 52$

$\begin{array}{lll}\cdots & \cdots & i b . \\ \cdots & \cdots & i b .\end{array}$

$\begin{array}{lll}\ldots & \ldots & i b . \\ \ldots & \ldots & i b .\end{array}$

$\cdots \quad \cdots \quad 51$

$\begin{array}{lll}\cdots & \cdots & 51 \\ \ldots & \ldots & 50\end{array}$

$\cdots \quad \cdots \quad 51$

$\cdots \quad \cdots \quad$ ib.

Inuus

I. assamensis

- leoninus

- nemestrinus

- rhesus

... 50

HERPESTIÖIN Æ...

Hipposideros

H. armiger ...

- cineraceus

- lankadiva ...

- larvatus ...

- murinus ...

...

… 49

... 25

- silenus

ib.

... 27

.. 26

- nobilis ...

- speoris $\ldots$. $\ldots$

HIPPOPOTAMIDA

Hippopotamus

H. capensis ...

HOMINID $\mathbb{E}$

Номо

H. Sapiens

HYæNa

... $\quad \ldots \quad i b$.

... 26

... 142

JACCHUS

J. vulgaris

$\ldots i b$.

... $\quad \ldots . \quad 1$

$\cdots \quad \cdots \quad 1$

... $\quad \ldots \quad i b$.

H $\cdots$

$\cdots \quad \cdots$

ib.

$\begin{array}{lllll}\text { - striata } & \ldots & \ldots & \ldots & 44\end{array}$

Hrenind: $\ldots$...

HYDROMYS ...

Lagenorthynchus

$\begin{array}{lll}\ldots & \ldots & 7\end{array}$

... $\quad \ldots \quad 8$

... $\quad \ldots \quad 7$

$\ldots . . . \quad i b$.

$\begin{array}{llr}\cdots & \cdots & \\ \cdots & \cdots & 8\end{array}$

8

J.

Kemas

K.

II. chrysogaster

II. leucogaster

Hyelathus ...

$\ldots-\ldots, 121$

L. leucopleurus

Lagonys

$\begin{array}{llll} & \ldots & & \\ & & \end{array}$

$\begin{array}{lllll}\text { KeRIVOULA } & \ldots & \ldots & \ldots & 34\end{array}$

K. pallida $\quad \therefore \quad \ldots e \quad \ldots \quad i b$.

$\begin{array}{lllll}\text { - picta } & \cdots & \ldots & \ldots & \text {... }\end{array}$

L.

... $i b$

$\begin{array}{llll}\ldots & \ldots & \ldots & 133\end{array}$

$\begin{array}{lll}\ldots & \ldots & \\ \ldots & \ldots & 122\end{array}$

L. roylei

... ib.

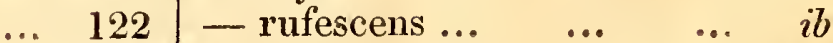

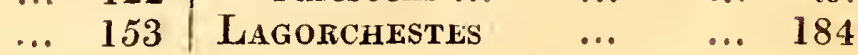


L. gymnotis ...

Lemur

L. albifrons ...

- catta

- macaco

- niger

- nigrifions ...

LEMURID

LEPORIDA

Lepus

L. capensis ...

- cuniculus ...

- hispidus ...

- nigricollis...

- pallipes ...

- peguensis ..

- ruficaudatus

- saxatilis ...

- sinensis ...

— timidus ...

- variabilis ...

LoRIS

L. gracilis $\ldots$

LuTrA

L. leptonyx ....

- nair

— vulgaris ...

LUTRIN $A$...

\section{M.}

\section{Macacus}

M. carbonarius

- cynomolgos

- pileatus ...

- radiatus ...

Macroglossus

M. minimus ...

MACROPODID ${ }^{*}$

Macropus

M. frænatus ...

- giganteus...

ManIs

- javanica ...

- leptura

- pentadactyla

Martes

M. abietum ...

- flavigula ...

- toufreus ...

- zibellina
Page.

... 184

-.

16

$\ldots$

$\cdots$

17

$i b$.

$\cdots$

$\cdots$

$\cdots$$$
\begin{array}{lll}
\ldots & \ldots & 16
\end{array}
$$$$
\ldots \quad \ldots 130
$$$$
\ldots \quad \ldots . \quad i b .
$$$$
\ldots \quad \ldots \quad i b \text {. }
$$$$
\begin{array}{lll}
\ldots & \ldots & 131
\end{array}
$$$$
\text { ... } \quad \ldots \quad 133
$$$$
\text { ... } \quad \text {.. } 132
$$$$
\text { ... } \quad \text {... } 131
$$$$
\text { ... } \quad \text {.. } 132
$$$$
\text { ... } \quad \ldots \quad 131
$$$$
\text { ... } \quad \ldots \quad 130
$$$$
\text { ... } \quad \text {... } 132
$$$$
\text { ... } \quad \ldots \quad 130
$$$$
\text { ... } \quad \text {... } 131
$$$$
\text { ... } \quad \ldots \quad 19
$$$$
\text { ... } \quad \ldots \quad i b \text {. }
$$$$
\text { ... } \quad \ldots \quad 71
$$$$
\text { ... } \quad \ldots \quad 73
$$$$
\text { ... } 72 \& 73
$$$$
\ldots \quad \ldots \quad 73
$$$$
\text { ... } \quad \ldots \quad 71
$$

$$
\text { (2) }
$$

MEgADERMa ..

Page.

M. horsfieldi, nobis ... $\quad$... 23

- lyra $\quad$... $\quad$... $\quad$... 22

$\begin{array}{lllll}\text { - spasma } & \ldots & \ldots & \ldots & \\ \text { - } & \text {... } & & \\ \end{array}$

MEGADERMATIN A $\quad \ldots \quad 22$

Megalotis $\ldots$...

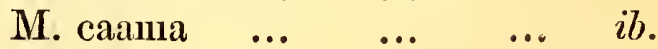

$\begin{array}{lllll}\text { Meles } & \ldots & \ldots & \ldots & 70\end{array}$

$\begin{array}{llll}\text { M. albogularis } & \ldots & \ldots & 71\end{array}$

$\begin{array}{lllll}-\operatorname{taxus} & \ldots & \ldots & \ldots & 70\end{array}$

MELIDIN $\ldots$ A $\quad \ldots .696$

Mellivora ... $\quad$... $\quad$... $i b$.

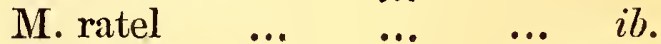

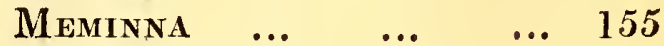

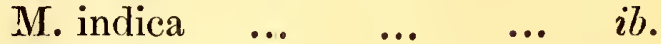

Monodon $\quad \ldots \quad$... $\quad \ldots .99$

M. monoceros $\quad$... $\quad$... $\quad i b$.

$\begin{array}{lllll}\text { Morunga } & \ldots & \ldots & \ldots & 79\end{array}$

M. proboscidea $\quad \ldots . \quad \ldots \quad i b$.

MOSCHIN 2 E $\quad \ldots . \quad \ldots \quad 154$

$\begin{array}{lllll}\text { Moschus } & \ldots & \ldots & \ldots & 157\end{array}$

M. moschifferas $\quad \ldots \quad \ldots \quad i b$.

Mungos $\quad \ldots \quad \quad \ldots \quad \ldots \quad \ldots 0$

M. fasciatus $\ldots . \quad \ldots \quad \quad \ldots \quad i b$.

- vitticollis... $\quad \ldots \quad \quad \ldots \quad i b$.

MURIDA $\ldots . \quad \ldots \quad \ldots \quad 110$

Murina $\quad \ldots \quad$... $\quad \ldots \quad 34$

M. suilla $\quad \ldots \quad \ldots \quad \quad \ldots \quad i b$.

Mus $\quad \ldots \quad \ldots \quad \ldots \quad \ldots \quad 112$

M. andamanensis $\quad \ldots \quad \ldots \quad \ldots \quad 114$

- badius ... $\quad . . \quad \ldots \quad \ldots 120$

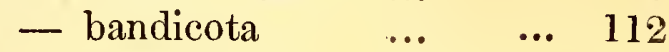

- cervicolar $\quad$... $\quad$... 119

- cinnamomeus $\quad$... $\quad \ldots \quad 115$

$\begin{array}{lllll}- \text { concolar } & . . & \ldots & \ldots & 116^{\circ}\end{array}$

- cunicularis $\quad \ldots . \quad \ldots \quad 119$

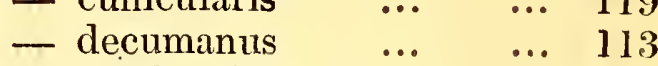

- erythrotis $\quad$... $\quad \ldots \quad 120$

- fulvidiventris $\quad \ldots \quad$... $\quad$.. 119

- gerbillinus $\quad \ldots \quad \ldots \quad i b$.

$\begin{array}{lllll}\text { - gliroides } \ldots & \ldots & \ldots & 120\end{array}$

\begin{tabular}{lllll} 
gouldii & $\ldots$ & $\ldots$ & $\ldots$ & 120 \\
\hline
\end{tabular}

- homourus . $\quad . . \quad \ldots \quad 118$

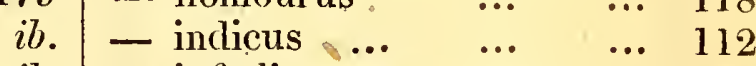

ib. - infralineatus $\quad \ldots . \quad \ldots .6116$

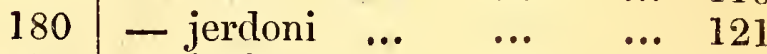

179 - lepidus $\ldots \quad$... $\quad \ldots \quad i b$.

66 - minutus ... $\quad \ldots \quad$... 117

ib. - musculus... $\quad \ldots \quad \ldots \quad \ldots \quad 118$

67 - nemoralis... $\quad . . \quad \ldots \quad \ldots \quad 114$

66 - nitidulus ... $\quad \ldots . \quad \ldots .119$

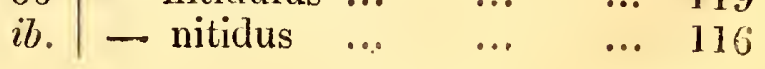


Page.

M. oleraceus ... $\quad \ldots \quad \ldots \quad 120$

- peguensis

- platythrix

- pumilus ...

- rattus ...

- robustulus

- rufescens...

- spinulosus

- sylvaticus

- terricolor...

- urbanus ...

Mustela $\quad$...

- erminea ...

- kathiah ...

- lutreola ...

- pusilla ...

- putorius ...

- sarmatica...

- sibirica

- subhemachalana ..

- vulgaris

MUSTELID $\dddot{Æ}$

Mropes

M. lemmus $\cdots$

Mrospalax ...

M. fuscocapillus

Mrotis

M. berdmorei

- murinus ...

- pipistrellus

MYOXID瓜

Myoxus

M. avellenarius

- glis

MYRMECOP̈HAGID

Myrmecophaga

M. gubata

N.

\section{NAMORHEDUS}

N. goral

Nasua

N. narica

NEodon

N. sikhimensis

NEOMERIS

N. phocænoides

Neotragus

N. saltiana ... NOC'TILIONINA....

Noctulinia ...
N. noctula ..

$\begin{array}{lll}\ldots & \ldots & 30\end{array}$

$\begin{array}{lll}\ldots & \ldots & 18\end{array}$

$\begin{array}{llll}\text { N. tardigradus } & \ldots & \ldots & i b .\end{array}$

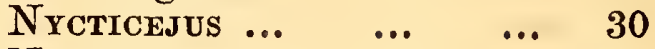

$\begin{array}{lllll}\text { N. atratus } & \ldots & \ldots & \ldots & 31\end{array}$

$\begin{array}{lllll}\text { - } \text { canus } & \ldots & \ldots & \ldots & 32\end{array}$

$\begin{array}{llll}\text { - castaneus... } & \ldots & \ldots & 31\end{array}$

$\begin{array}{lllll}\text { - gouldii } & \ldots & \ldots & \ldots & 32\end{array}$

$\begin{array}{lllll}\text { - heathii } & \ldots & \ldots & \ldots & 30\end{array}$

$\begin{array}{lllll}\text { - luteus } & \ldots & \ldots & \ldots & \\ \text { - } & \ldots & & & \end{array}$

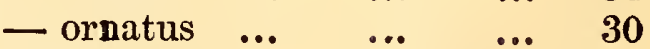

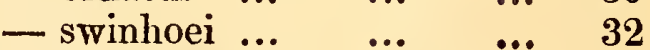

$\begin{array}{lllll}- \text { tickelli } & \ldots & \ldots & \ldots & 31\end{array}$

$\begin{array}{llll}- \text { temminckii } & \ldots & \ldots & i b .\end{array}$

$\begin{array}{lllll}\text { Nycteris } & \ldots & \ldots & \ldots & \\ \text { ne } & \ldots & 28\end{array}$

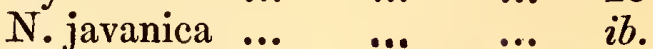

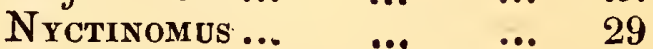

$\begin{array}{lllll}N \text {. insignis } & \ldots & \ldots & \ldots & i b .\end{array}$

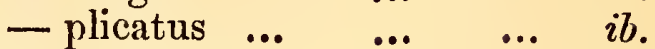

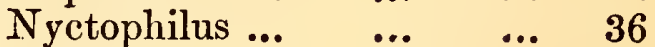

$\begin{array}{llll}\text { N. geoffroyi } & \ldots & \ldots & \ldots\end{array}$

O.

$\begin{array}{lllll}\text { Octodon } & \ldots & \ldots & \ldots & 127\end{array}$

$\begin{array}{lllll}\text { O. degus } & \ldots & \ldots & \ldots & i b .\end{array}$

OCTODONTID

$\begin{array}{lllll}\text { Oreas } & \ldots & \ldots & \ldots & 164\end{array}$

$\begin{array}{lllll}\text { O. canna } & \ldots & \ldots & \ldots & i b .\end{array}$

Oreotragus ... $\quad \ldots . \quad \ldots \quad 167$

$\begin{array}{llll}\text { O. saltratrix } \ldots & \ldots & \ldots & i b .\end{array}$

ORNITHORHYNCHUS ... $\quad \ldots \quad 186$

$\begin{array}{lllll}\text { O. anatinus } & \ldots & \ldots & \ldots & i b .\end{array}$

$\begin{array}{llll}\text { Orycteropus } & \ldots & \ldots & 178\end{array}$

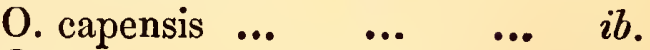

$\begin{array}{lllll}\text { Oryx } & \ldots & \ldots & \ldots & 169\end{array}$

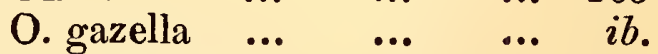

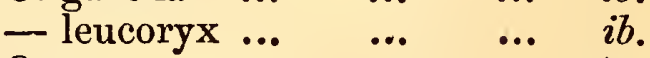

$\begin{array}{lllll}\text { Ovis } & \ldots & \ldots & \ldots & 177\end{array}$

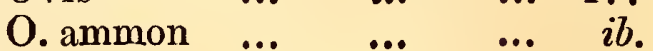

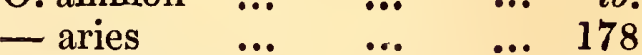

$\begin{array}{llll}- \text { cycloceros } & \ldots & \ldots & 177\end{array}$

$\begin{array}{lllll}- \text { nahura } & \ldots & \ldots & \ldots & 178\end{array}$

P.

$\begin{array}{lllll}\text { Panolia } & \ldots & \ldots & \ldots & 149\end{array}$

$\begin{array}{lllll}\text { P. eldi } & \ldots & \ldots & \ldots & i b .\end{array}$

$\begin{array}{lllll}\text { Papio } & \ldots & \ldots & \ldots & 6\end{array}$

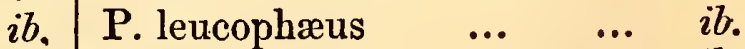

29 - maimon $\ldots . \quad \ldots \quad$... $\quad i b$.

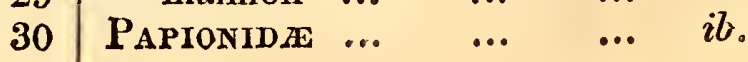


Page.

Paradoxurus $\quad \ldots . \quad \ldots \quad 46$

Pr. barbei ... ...

Page.

P. grayi $\quad \ldots \quad$... $\quad \ldots .48$

... 14

- laniger $\quad \ldots . \quad \ldots \quad \quad \ldots \quad i b$.

- cephalopterus ... $\quad$... 13

- laniger ....

- leucotis ...

- musanga ...

- rubidus ...

- trivirgatus

- zeylanicus

$\cdots \quad \cdots \quad i b$.

- clicullatus

- entellus ...

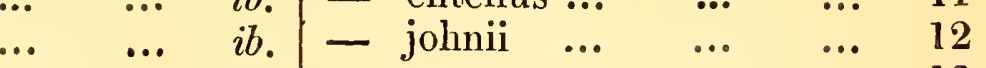

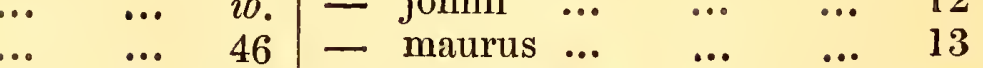

.. $\quad \ldots \quad 48 \quad-$ obscurus... $\quad \ldots \quad \ldots .14$

Pectinator ...

... $\quad$... 47

... $\quad \ldots \quad i b$.

P. spekei

... 130

PECTINATÖRID $\dddot{\mathbb{A}}$

... ib.

Perameles ... ...

... ib.

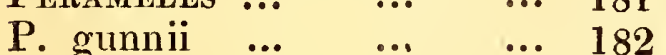

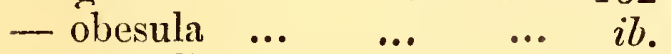

PERAMELID $\mathbb{E}$...

Petaurus $\quad \ldots \quad$...

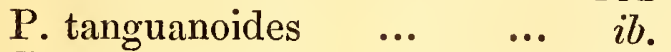

Phacochoerus

$\begin{array}{ccc}\ldots & \ldots & 139 \\ \ldots . . & \ldots & i b .\end{array}$

$\mathrm{Ph}$. æthiopicus

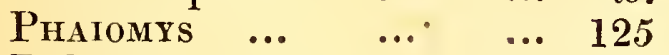

P. leucurus ... ...

PHALANGISTID

Phalangista

Ph. vulpina ...

\section{A}

... ib.

... 182

... 182

… ib.

Phascogale...

$\cdots$

$\cdots$

PHASCOLOMYID $\dddot{\text { AE }}$

Priascolomys

$\mathrm{Ph}$. wombat ...

Phoca

Ph. barbata ...

PHOCANA

$\mathrm{Ph}$. communis

PHOCID E ...

Platacanthomys ...

Pl. lasiurus $\quad . . \quad$...

Platanista ... ...

... 181

$\ldots . \quad i b$

... 186

... $i b$.

... $i b$.

... 78

... ib.

... 88

... ib.

... 77

... 109

... ib.

... 92

$\begin{array}{llll}\text { Pl. gangetica } & \ldots & \ldots & i b \text {. }\end{array}$

$\begin{array}{lllll}- \text { indi } & \ldots & \ldots & \ldots & i b .\end{array}$

$\begin{array}{lllll}\text { Pleocotus } & \ldots & \ldots & \ldots & 35\end{array}$

$\begin{array}{lllll}\text { Pl. auritus } & \ldots & \ldots & \ldots & i b .\end{array}$

$\begin{array}{lllll}\text { Ponabrus } & \ldots & \ldots & \ldots & 181\end{array}$

P. crassicaudatus $\quad \ldots . \quad \ldots . \quad i b$.

$\begin{array}{lllll}\text { Poephagus } & \ldots & \ldots & \ldots & 158\end{array}$

$\begin{array}{llll}\text { P. grunniens... } & \ldots & \ldots & i b .\end{array}$

Portax

P. tragocamelus

Potamochares

P. africanus ...

Presbytis ...

Pr. albocinerus

... $\quad \ldots \quad 165$

... $\quad \ldots \quad i b$.

... $\quad \ldots \quad 142$

- phayrei ...

- pileatus ...

- priamus...

- schistaceus

- ursinus ...

Prionodon ...

Pr. pardicolor

Procapra ...

Pr. picticaudata

... $\quad \ldots \quad 15$

Procyon ...

... $\quad \ldots \quad 12$

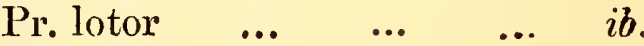

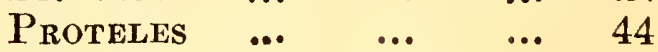

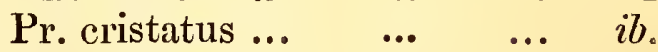

$\begin{array}{lllll}\text { Psammomys } & \ldots & \ldots & \ldots & 111\end{array}$

$\begin{array}{lllll}\text { Ps. obesus } & \ldots & \ldots & \ldots & i b .\end{array}$

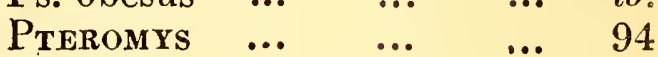

$\begin{array}{llll}\text { Pt. cineraceus } & \ldots & \ldots & i b .\end{array}$

$\begin{array}{llll}\text { - inornatus... } & \ldots & \ldots & 95\end{array}$

— magnificus $\quad \ldots . \quad \ldots \quad i b$.

$\begin{array}{lllll}\text { — nitidus } & \ldots & \ldots & \ldots & 96\end{array}$

$\begin{array}{llll}\text { - petaurista } & \ldots & \ldots & 94\end{array}$

PTEROMYDIN死... $\quad . . \quad i b$.

PTEROPODID A ... ... 20

$\begin{array}{lllll}\text { Pteropus } & \ldots & \ldots & \ldots & i b .\end{array}$

$\begin{array}{lllll}\text { Pt. edulis } & \ldots & \ldots & \ldots & i b .\end{array}$

- edwardsii $\quad \ldots \quad$...

- leschenaultii $\quad . . \quad \ldots \quad 21$

- melanotus, nobis $\quad$... 20

- poliocephalus ... ...

R.

$\begin{array}{lllll}\text { Rhinoceros ... } & \ldots & \ldots & 136\end{array}$

$\begin{array}{llll}\text { Rh. africanus } & \ldots & \ldots & 138\end{array}$

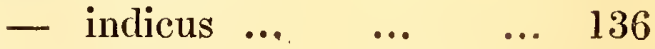

$\begin{array}{lllll}\text { - } \operatorname{simus} & \ldots & \ldots & \ldots & 138\end{array}$

$\begin{array}{llll}\text { - } & \text { sondaicus } \quad \ldots & \ldots & 137\end{array}$

- sumatranus $\quad \ldots \quad$...

RHINOCEROTIDE $\quad \ldots \quad 136$

RHINOLOPHINAE $\quad \ldots \quad 23$

$\begin{array}{llll}\text { Rhinolophus } & \ldots & \ldots & i b .\end{array}$

$\begin{array}{lllll}\text { Rh. affinis } & \ldots & \ldots & \ldots & 24\end{array}$

... ib. - brevitarsus ... $\ldots . \quad i b$.

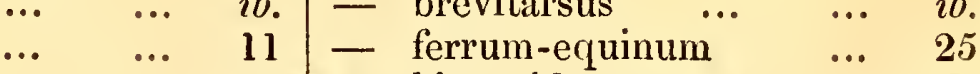

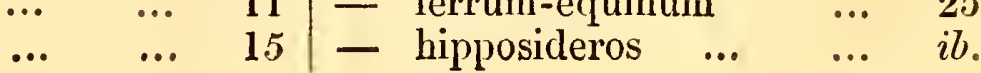


Rl. macrotis...

- mitratus ...

- pearsoni ...

- perniger...

- rouxi ...

- subbadius

- tragatus ...

Rhinopoma ...

Rh. hardwickii

Rhinosciurus

Rh. tupaoides

Rhizomys

Rh. badius ...

- castaneus

- pruinosus

- sumatrensis

Rucervus

R. duvaucelii

Rusa

R. aristotelis...

- tunjuc $\ldots$

S.

Sarcophitus...

S. ursinus

Sc. aquaticus

SCIURID E..

Sciuropterus

Sc. alboniger...

- caniceps ...

- fimbriatus

- fuscocapillus

- phayrei ...

- spadiceus...

- villosus ...

- volucella...

Sciurus

Sc. albipes $\quad \ldots$

- assamensis

- atrodorsalis

- barbei

- berdmorei

- bicolor

- blanfordii

- castaneoventris

- chrysonotus

- concolor ...

- elphinstonei

- ephippium

...

...

\section{Page.}

.. 25

$\begin{array}{lll}\cdots & \ldots & 25 \\ \cdots & \ldots & 23\end{array}$

... $\quad$.. 24

... $\quad \ldots \quad 23$

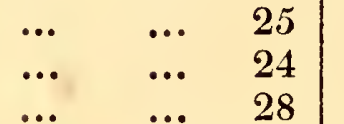

... $\quad \ldots \quad 28$

$\begin{array}{lll}\ldots & \ldots & i b .\end{array}$

$\begin{array}{lll}\ldots & \ldots & 108\end{array}$

$\begin{array}{rrr}\ldots & \ldots & i b . \\ \ldots & \ldots & 122\end{array}$

$\begin{array}{rrr}\ldots & \ldots & 122 \\ \ldots & \ldots & i b .\end{array}$

... $\quad \ldots \quad 123$

$\begin{array}{lll}\ldots & \ldots & 122\end{array}$

$\ldots \quad \ldots \quad i b$.

$\begin{array}{llr}\ldots & \ldots & 150\end{array}$

... $\ldots$

$\ldots$

... $\quad$.

$\begin{array}{llr}\ldots & \ldots & 151 \\ & \ldots & 149\end{array}$

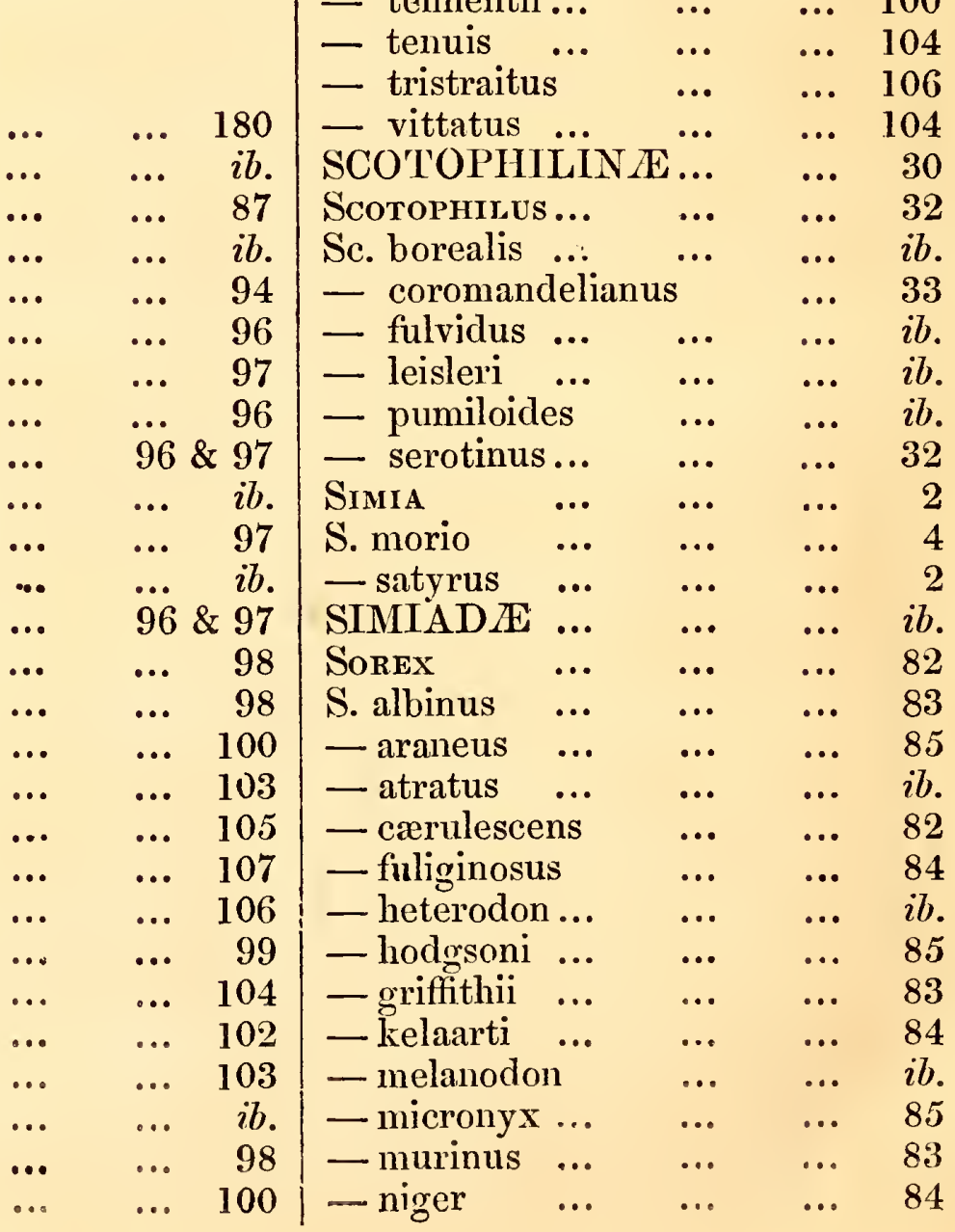


S. nudipes $\quad \ldots \quad \quad \ldots \quad \quad \ldots \quad 84$

- serpentarius $\quad$... $\quad \ldots .83$

- soccatus ...

Soriculus ...

S. nigrescens ...

Spalax $\quad \ldots$

Sp. typhlus ...

Sparocopus ...

Sp. pöeppigii...

Steno

St. attenuatus

- frontatus...

Strepsiceros

Str. kudu

SUIDE

Sus

S. andamanensis

- scropha ..

T.

Talpa

T. europma $\cdots$

- leucura ...

- microura ...

TAPHOZOIN E

Taphozous ...

$\mathrm{T}$. longimanus

- saccolaimus

Tapirus

T. malayanus

Tarandus

T. rangifer ...

Taxidea

T. leucura ...

Tetracerus ...

T. quadricornis

Thylacinus ...

Th. cynocephalus

TRICHECHIN $\mathrm{E}$

Trichechus ...

Tr. rosmarus...

TRAGELAPHIN A

Tragors

Tr. bennettii.

Tragulus ...

Tr. javanicus

- kanchil

- pelandog...

Troglodytes

Tr. niger

Tupara

'I. elliotti $\begin{array}{lll}\ldots & \ldots & 84 \\ \ldots & \ldots & 84\end{array}$

... $\quad \ldots \quad 86$

.. $\quad \ldots \quad i b$.

$\begin{array}{lll}\ldots & \ldots & 126\end{array}$

$\begin{array}{lll}\ldots & \ldots & i b .\end{array}$

... $\quad \ldots \quad 127$

... $\quad \ldots \quad i b$.

... $\quad \ldots \quad 91$

... $\quad \ldots 99$

$\begin{array}{lll}\ldots & \ldots & 91\end{array}$

$\begin{array}{lll}\ldots & \ldots & 165\end{array}$

... $\quad \ldots \quad i b$.

$\begin{array}{lll}\ldots & \ldots & 139\end{array}$

... $\quad \ldots \quad i b$.

$\begin{array}{lll}\ldots & \ldots & \\ \ldots & \ldots & 141\end{array}$

$\begin{array}{lll}\ldots & \ldots & 139\end{array}$

$\begin{array}{lll}\ldots & \ldots & 88 \\ & & \end{array}$

$\ldots . . . \quad i b$.

$\ldots \quad \ldots \quad i b$.

... $\quad \ldots \quad i b$.

.. $\quad \ldots \quad 28$

.. $\quad \ldots \quad i b$.

$\begin{array}{lll}\ldots & \ldots & \\ \cdots & \ldots & 29\end{array}$

... $\quad$.. 28

$\begin{array}{lll}\ldots & \ldots & \\ \ldots & \ldots & 134\end{array}$

$\begin{array}{lll}\ldots & \ldots & 135 \\ \ldots & \ldots & 135\end{array}$

$\begin{array}{lll}\ldots & \ldots & 135 \\ \ldots & \ldots & 145\end{array}$

... $i b$.

... 70

... ib.

... 165

... ib.

... 180

$\ldots \quad i b$.

... 79

... ib.

... ib.

... 164

... 172

... 173

... 155

... ib.

... 156

... ib.

... 2

... 2

... 81

... 82
T. ferruginea

Page.

$\begin{array}{lllll}\text { - javanica } & \ldots & \ldots & \ldots & 82\end{array}$

$\begin{array}{lllll}-\operatorname{tana} & \ldots & \ldots & \ldots & 81\end{array}$

U.

URsus

U. arctos $\quad \cdots$

— isabellinus

- labiatus ...

- malayanus

- maritimus

- tibetanus...

URVA

U. cancrivora

... $\quad \ldots \quad 75$

... $\quad \ldots \quad i b$.

... $\quad \ldots \quad 76$

... $\quad \ldots \quad 77$

... $\quad \ldots \quad 76$

... $\quad \ldots \quad 75$

... $\quad \ldots \quad 76$

... $\quad \ldots \quad 49$

.. $\quad \ldots \quad i b$.

V.

VAMPYRIDA

Vespertilio... $\quad$... 34 \& 35

V. adversus ... $\quad \ldots \quad \quad \ldots \quad 35$

— pearsonii ... $\quad \ldots . \quad \ldots \quad 34$

VESPERTILIONINA $\ldots . \quad i b$.

$\begin{array}{lllll}\text { ViverRa } & \ldots & \ldots & \ldots & 44\end{array}$

V. civettina $\ldots . . \quad \ldots . \quad \ldots . \quad$...

- tanggalunga $\quad \ldots \quad \ldots \quad 45$

- zibetha $\quad . . \quad \quad \ldots \quad \quad \ldots \quad i b$.

$\begin{array}{llll}\text { ViverRicula } & \ldots & \ldots & i b \\ \text { V. } & \end{array}$

V. malaccensis $\quad \ldots \quad \ldots . \quad$...

VIVERRIDA $\quad \ldots \quad \ldots .43$

VIVERRIN

$\begin{array}{lllll}\text { VulPes } & \ldots & \ldots & \ldots & 4 \\ \text { Vulavescen }\end{array}$

V. flavescens... $\quad \ldots \quad \quad \ldots \quad i b$.

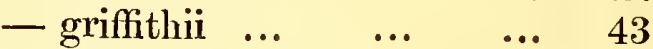

$\begin{array}{lllll}\text { - lagopus } \quad . . & \ldots & \ldots & 42\end{array}$

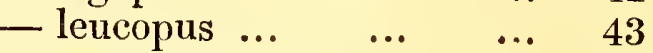

- montanus ... $\quad$... $\quad \ldots \quad 42$

- pusillus ... $\quad$... $\quad$... 43

- virginianus $\quad \ldots . \quad \ldots \quad i b$.

$\begin{array}{lllll}\text { - vulgaris } & \ldots & \ldots & \ldots & 42\end{array}$

$\mathrm{X}$.

$\begin{array}{llll}\text { Xantharpyia } & \ldots & \ldots & 21\end{array}$

X. amplexicaudata ... $\quad . . \quad i b$.

- hottentota $\quad . . \quad$... ib.

$\begin{array}{lllll}\text { Xerus } & \ldots & \ldots & \ldots & 108\end{array}$

X. rutilans $\quad \ldots \quad \ldots . \quad \ldots \quad \ldots \quad$ ib.

- $\operatorname{setosus~...~} \quad . . \quad \ldots \quad i b$.

Z.

$\begin{array}{lllll}\text { Zebus } & \ldots & \ldots & \ldots & 159\end{array}$

Z. gibbosus $\ldots . \quad \ldots \quad \quad \ldots \quad i b$.

$\begin{array}{llllll}\text { ZORILLA } & \ldots & \ldots & \ldots & 69\end{array}$

Z. striata $\quad \ldots \quad \ldots . \quad \ldots \quad i b$. 








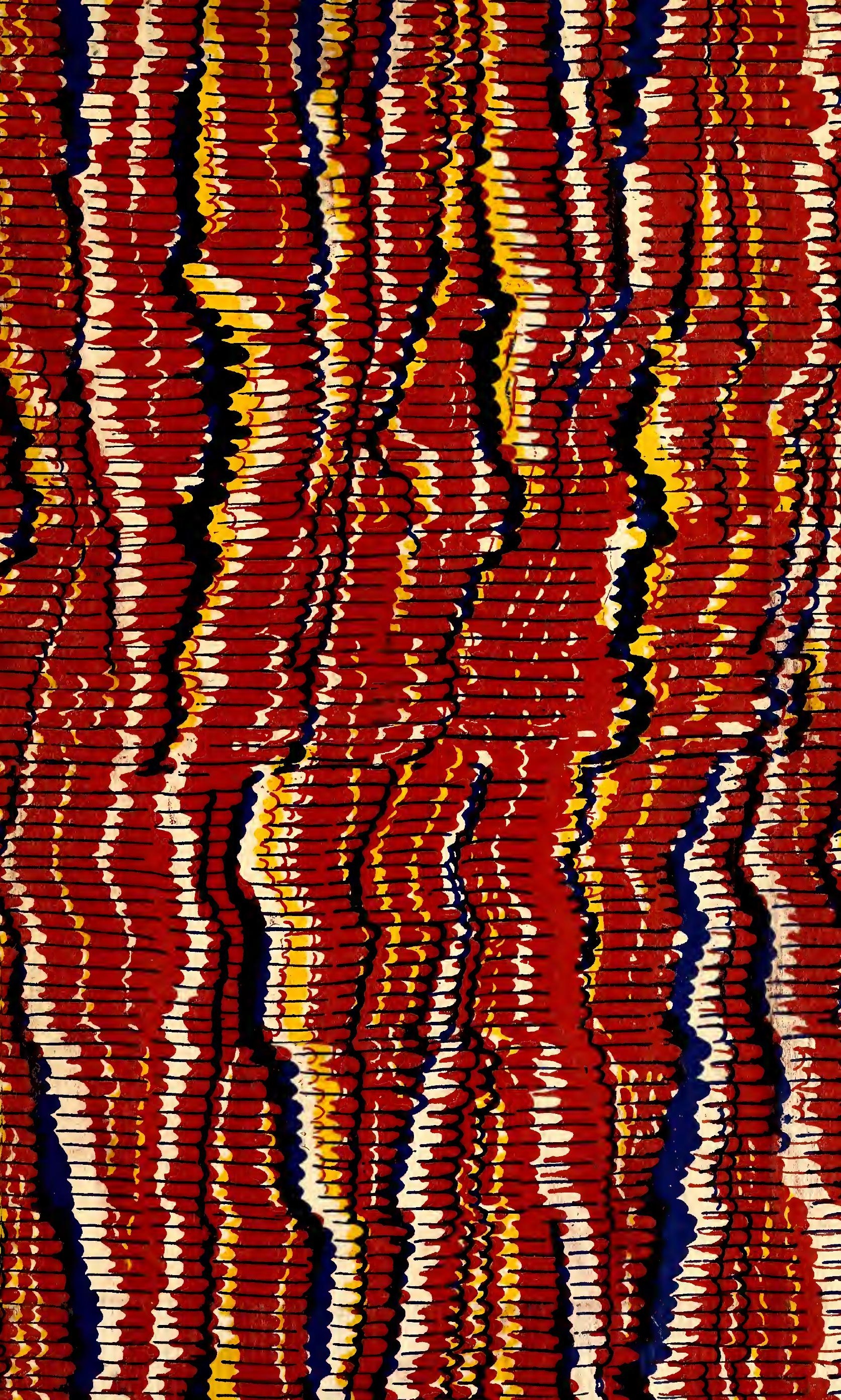


SMITHSONIAN INSTITUTION URRARIES

|| || || || |||||||||||||| INSTITUTION LIBRARIES

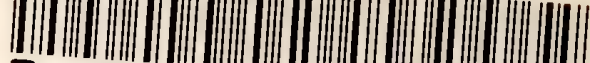

39088003186392

Catalogue of thm QL71.142C14

Catalogue of the mammalia in the Museum 